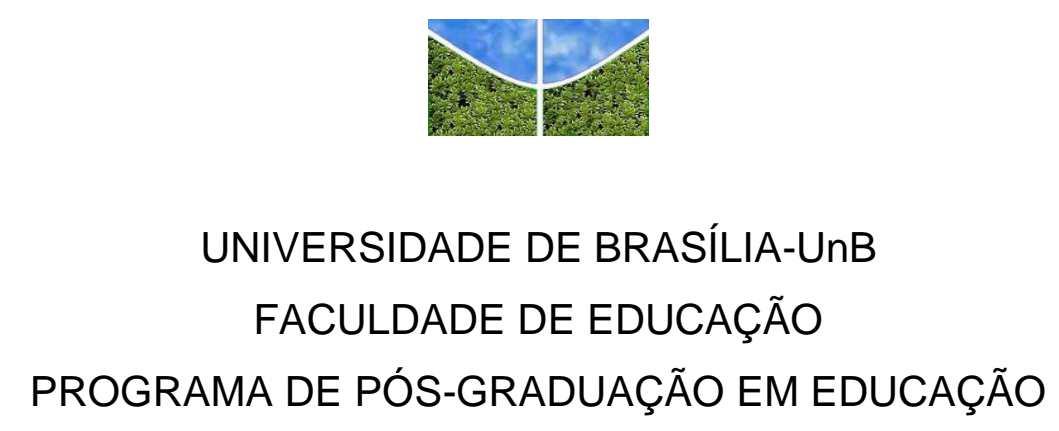

ATIVIDADES COTIDIANAS E O PENSAMENTO CONCEITUAL

Ingrid Lilian Fuhr Raad

Brasília, 2013 
UNIVERSIDADE DE BRASÍLIA - UnB

FACULDADE DE EDUCAÇÃO

PROGRAMA DE PÓS-GRADUAÇÃO EM EDUCAÇÃO

\title{
ATIVIDADES COTIDIANAS E O PENSAMENTO CONCEITUAL
}

\author{
Ingrid Lilian Fuhr Raad
}

Tese apresentada ao Programa de Pós-Graduação em Educação da Faculdade de Educação da Universidade de Brasília/UnB como parte dos requisitos para a obtenção do título de Doutor em Educação na área de: Escola, Aprendizagem e Trabalho Pedagógico.

Brasília, 2013 
UNIVERSIDADE DE BRASÍLIA - UnB

FACULDADE DE EDUCAÇÃO

PROGRAMA DE PÓS-GRADUAÇÃO EM EDUCAÇÃO

TESE DE DOUTORADO

ATIVIDADES COTIDIANAS E O PENSAMENTO CONCEITUAL

Ingrid Lilian Fuhr Raad

Orientadora: Elizabeth Tunes

Comissão Examinadora

Profa. Dra. Elizabeth Tunes

(Orientadora)

Prof. Dr. Roberto Bartholo Júnior

Universidade Federal do Rio de Janeiro

Prof. Dr. Roberto Silva Universidade de Brasília

Profa. Dra. Zoia Prestes Universidade Federal Fluminense

Profa. Dra. Patricia Lima Martins Pederiva Universidade de Brasília

Profa. Dra. Cristina M. Madeira Coelho Universidade de Brasília (suplente) 


\section{AGRADECIMENTOS}

O doutorado foi uma vivência singular, difícil de ser retratado em palavras, pois elas não explicitam toda a dimensão do vivido. Na verdade, foram quatro anos de riquíssimo aprendizado, de desafios a serem vencidos e de enfrentamento das adversidades sempre presentes na vida. Nessa caminhada, houve ocasiões que exigiram isolamento para pensar e amadurecer as ideias, de modo a materializar o pensamento em texto escrito. Enfim, vale ressaltar que os momentos dedicados a este trabalho foram de satisfação íntima e de muita felicidade e alegria. Destarte, não realizei a caminhada sozinha, tive a companhia de pessoas que caminharam ao meu lado e nos momentos difíceis estenderam-me a mão, para que seguisse em frente. O meu muito obrigada:

às amigas de longa caminhada: Carla, Penélope e Zoia, que sempre dispostas e presentes, provocaram-me a pensar em questões importantes para este trabalho, seja em momentos de estudo ou de profunda descontração. A convivência dialógica com todas elas nutre e alegra minha vida...

à Elza, saudosa amiga, pelo convívio e companheirismo ...

aos amigos Lúcio e Edna, um encontro fraterno e dialógico, que tão prontamente compartilharam comigo de estudos e de reflexões pertinentes à pesquisa...

à amiga Larissa, pela leitura crítica e gentil na revisão dos textos...

ao Eric, pelo carinhoso presente ...

à minha amada amiga taita Mary, que esteve comigo em cada momento dessa caminhada, sempre disponível a me auxiliar e apoiar em todas as situações que precisei...

aos amados Jacó, Fofoca, Rhorocho e Duke pelo carinho e aconchego...

à minha tia Doly, uma mulher de fibra e alegre com a vida, que mesmo distante geograficamente, esteve ao meu lado incentivando-me em cada percurso dessa caminhada...

aos meus filhos Yasmin, William e Mikhael, que muito sentiram minha ausência, tiveram que aprender a esperar, a dividir e a respeitar o meu tempo ... 
ao meu amigo e amado Nizar, que superou momentos de solidão e respeitou o meu compromisso com este trabalho ...

ao amigo Hamistin e a todas as falanges que me acompanharam e seguiram ao meu lado...

ao meu pai, que soube compreender minha necessidade de recolhimento e de afastamento em encontros familiares...

à Capes, pelo apoio financeiro com bolsa de pesquisa ...

ao Felipe, pela parceria e coleguismo na estruturação dos mapas conceituais ...

à Patrícia, por sua presença nas primeiras indagações que constituíram este trabalho e pelas boas sugestões ...

à Cristina, por aceitar o convite para o diálogo ...

ao Bob, pelo carinho e atenção em longas conversas a respeito de questões que permearam a pesquisa e pelas contribuições que a impulsionaram...

ao Bartholo, que com sua presença e abertura ao diálogo, apontou outras possibilidades e novos olhares para esta pesquisa e, para finalizar,

o meu eterno agradecimento a minha amiga e orientadora Beth, que por sua mestria e sabedoria se fez presente em todos os momentos. O nosso encontro é um marco em minha vida. Conviver com ela possibilita sempre um novo aprender. É uma pessoa que vive o sentido das palavras de Arendt (1978b, p.156): "Amo: vollo ut sis". 


\section{RESUMO}

$\mathrm{Na}$ sociedade contemporânea é bastante difundida a ideia de que o conhecimento científico é superior ao conhecimento que se forja nas atividades cotidianas. Para acessar o conhecimento científico, é preciso ingressar na escola, que cumpre a função de controle e tutela social do processo de ensinoaprendizagem. Os conceitos científicos são convertidos em conteúdos curriculares didatizados e relacionados aos conceitos cotidianos para serem compreendidos; assim, eles são transformados em conceitos escolares, que apresentam um caráter híbrido. Para analisar a suposta superioridade dos conceitos científicos sobre os cotidianos tomou-se, como referência, os estudos de Vigotski, que elaborou um trabalho sistemático sobre essa distinção. Para o exame da referida distinção, esclareceu-se o que vem a ser o cotidiano e o conhecimento científico, ou seja, a natureza das atividades cotidianas e científicas. No presente estudo, procede-se a uma descrição e a uma análise dos modos de organização do pensamento conceitual de duas atividades: a do artesão ourives e a do sineiro. Verificou-se que o pensamento deles contém conceitos provenientes da ciência e conceitos provenientes da própria atividade. Com todos os exames realizados, foi possível apontar indícios de que os conhecimentos são híbridos e de que há uma infinidade de modos de conhecer e operar o pensamento por conceito, seja na ciência, seja na atividade escolar ou na artesanal.

Palavras-chave: pensamento conceitual, hibridização do conhecimento, atividades cotidianas. 


\section{Résumé}

Dans notre société contemporaine, il est bien répandu l'idée que la connaissance scientifique est supérieure à celle qui se construit dans les activités quoditiennes. Pour avoir accès à la connaissance scientifique, il faut entrer dans l'école, qui a comme rôle le contrôle et la tutelle sociale de l'apprentissage. Les conceptes scientifiques sont convertis dans des contenus corriculaires didactisés et, au même temps, liés à des conceptes quotidiens pour être bien compris; ainsi, ils sont transformés dans des conceptes scolaires, qui présentent une caractéristique hybride. Afin d'analyser la soi-disante supériorité des connaissances scientifiques face aux connaissances quotidiennes on a pris, comme point de repère, les études de Vygotski, qui a elaboré un travail systématisé sur cette distinction. Tenant pour but examiner cette distinction, on a eclairé ce qui est quotidien et ce qui est connaissance scientifique, cela veut dire, la nature des activités quotidiennes et scientifiques. Dans notre étude, on a fait une description et une analyse de la façon d'organisation de la pensée conceptuelle de deux activités, celle de l'artisan orfèvre et celle du fondeur de cloche. On a vérifié que dans leur pensée il y a des conceptes qui sont issus de la science et des conceptes qui sont issus de leur propre activité. D'après l'analyse des données, il a été possible de voir des índices vers des connaissances hybrides et, encore, qu'il y a une grande quantité de manières de connaître et de mettre en action une pensée par concepte, soit dans la science, soit dans l'activité scolaire ou soit dans l'activité artisanale.

Mots-clés: pensée conceptuelle, hybridation de la connaissance, des activités quotidiennes. 


\begin{abstract}
In contemporary society, the idea that scientific knowledge is superior to the knowledge originated from everyday activities is widespread. Those who wish to have access to scientific knowledge must attend school, which controls and exerts social custody over the teaching-learning process. Scientific concepts are changed into didactic content and related to everyday concepts, so that they can be understood by students; thus, scientific concepts are transformed into school concepts, which are hybrid. In order to analyze the supposed superiority of scientific concepts over everyday concepts, we have used, as a theoretical reference, the works of Vygotsky, who developed a systematic work on that distinction. In order to examine that distinction, we discuss the definitions of everyday knowledge and scientific knowledge, that is, the nature of everyday activities and scientific activities. In this work, the organization of conceptual thinking involved in two activities goldsmithing and bell founding - are described and analyzed. It was observed that their thinking processes involve concepts that originated from science and from their own professional activities. It was possible to identify evidence for the fact that knowledge is hybrid and there are innumerous ways of gaining knowledge and operating conceptual thinking, whether in science, in school activities or in crafting.
\end{abstract}

Keywords: conceptual thinking, knowledge hybridization, everyday activities. 


\section{LISTA DE ILUSTRAÇÕES}

Figura 1- Um exemplar de mapa conceitual sobre as razões da existência das estações do ano.

Figura 2- Peças originais utilizadas por Vigotski em seus experimentos com o método funcional de dupla estimulação. .35

Figura 3- Armas e ferramentas criadas durante a Idade dos Metais. 100

Figura 4- Armas e ferramentas criadas durante a Idade dos Metais......................100

Figura 5- Adorno pré-histórico. Perfil humano com tema animal...........................101

Figura 6- Ornamento em ouro - Idade dos metais............................................101

Figura 7- Parte superior de anel em ouro com selo incrustado..............................101

Figura 8- Vaso cita de ouro (século IV a.C.)...................................................101

Figura 9- Pente cita (século IV a. C.) ……………..........................................102

Figura 10- Pantera que adornava escudo (cita-siberiano)....................................102

Figura 11- Joias de dama da corte Shub-ab (Ur, 2800a.C.)................................103

Figura 12- Arte zoomórfica cita (séculos VII e VI a. C.).........................................103

Figura 13- Braceletes etruscos (século VII a.C.)..............................................104

Figura 14- Bracelete persa (séc. V e IV a.C.)...................................................105

Figura 15- Diademas etruscos em ouro e filigrana ..............................................105

Figura 16- Anel com cravação inglesa - granada, safira e esmeralda

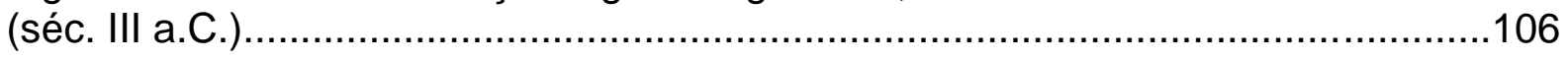

Figura 17- Relicário bizantino (século X)....................................................106

Figura 18- Encadernação esmaltada com pérolas (século IX)................................107

Figura 19- Colar indiano estilo mongol com pedras naturais, translúcidas e polidas em forma de cabochão (século XIV)..................................................107

Figura 20- Broche floral, Espanha (séc. XVIII) ...............................................108

Figura 21- Tritão em pérola e pedras (séc. XVI) ...............................................109 


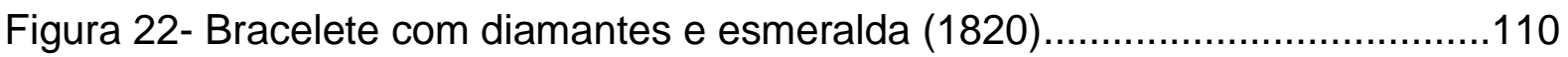

Figura 23- Bancada de trabalho da oficina do Álvaro....................................114

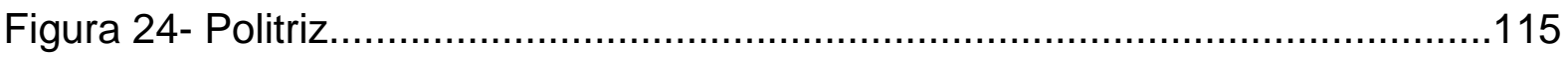

Figura 25- Maçarico ............................................................................ 116

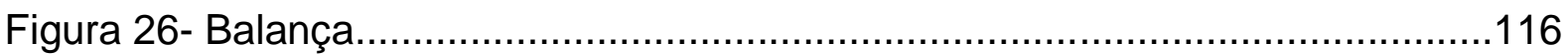

Figura 27- Equipamento para eletrólise ..................................................117

Figura 28- Laminador, paquímetro e o ouro laminado......................................117

Figura 29- Laminador, alargador, caixa de fundição, maçarico, suporte de cadinho, aneleira, martelos, dado de bolas, alargador de aliança....................118

Figura 30- Queijinho de símbolos.......................................................119

Figura 31 - Símbolo do Direito......................................................................119

Figura 32- Alicates, martelos, dados de bolas, fieira, alargador, aneleira,

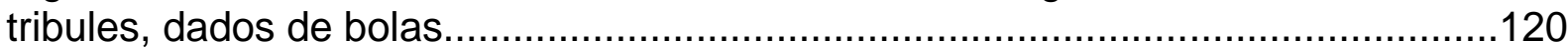

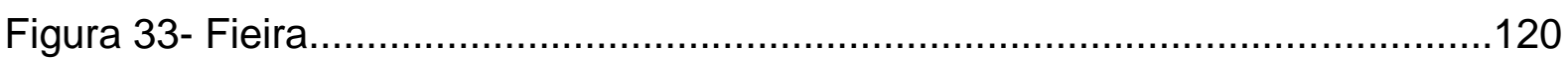

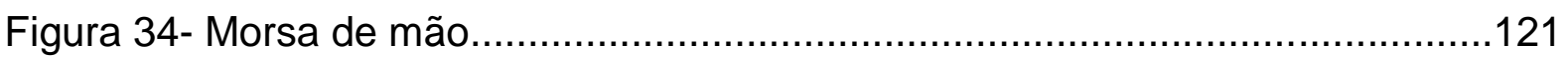

Figura 35- Anel na morsa para cravar a pedra............................................121

Figura 36- Suporte de cadinho, cadinho e releira..............................................122

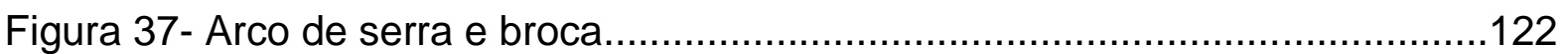

Figura 38- Célula extraída do mapa conceitual do ourives William que retrata os serviços prestados................................................................. 127

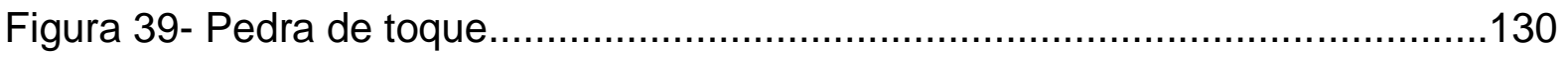

Figura 40- Célula extraída do mapa conceitual dos ourives Álvaro........................131

Figura 41- Célula extraída do mapa conceitual do ourives Álvaro..........................132

Figura 42- Célula extraída dos mapas conceituais dos ourives...........................133

Figura 43- Célula extraída do mapa conceitual do ourives William........................134

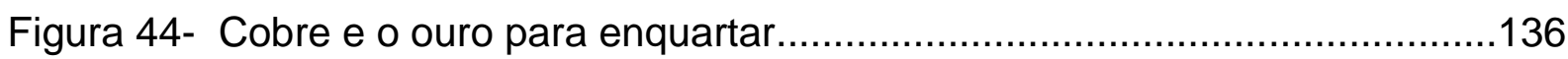


Figura 45- Fusão do ouro enquartado

Figura 46- Ouro enquartado e laminado.

Figura 47- Picar o ouro laminado para reagir rápida com o ácido.

Figuras 48 e 49- O ácido nítrico é depositado em um recipiente juntamente com o ouro enquartado picado. A reação resulta em fumaça avermelhada com a liberação do cobre.

Figura 50- Após 24h de reação, o ouro fica depositado no fundo do recipiente

Figura 51- O ouro é colocado na panela esmaltada e aquecido para secagem.

Figura 52- Ouro puro após secagem.

Figura 53- Antes de fundir o ouro, passa-se o bórax

Figura 54- Ouro purificado

Figura 55- Célula extraída do mapa conceitual do ourives Álvaro

Figura 56- Célula extraída do mapa conceitual do ourives William para

o conceito supraordenado de metais.

Figura 57- Célula extraída do mapa conceitual do ourives Álvaro para o conceito supraordenado de ácidos.

Figura 58- Fachada da Fundição Artística de Sinos Uberaba/FASU.

Figura 59- Sequência das principais etapas

Figura 60- Bases para os braseiros.

Figura 61- Mastro fixado, etapa inicial de fabricação de sinos

Figura 62- Chapelona, linha externa e interna - diferentes tamanhos. 150

Figura 63- Betoneira.

Figura 64- Estágio inicial da fabricação, levantamento da forma de tijolos amarrada com arames.

Figura 65- Formas prontas sendo aquecidas no braseiro.

Figura 66- Usinagem do macho, parte interna do perfil. .156

Figura 67- Macho usinado 
Figura 68- Machos com unto

Figura 69- Sinos usinados após o unto de cinza com água....................................158

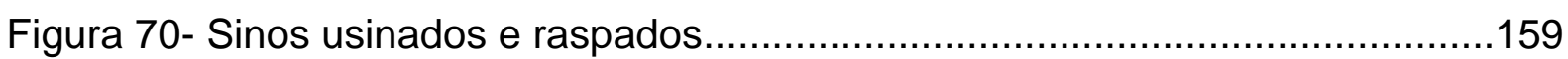

Figura 71- Sino raspado, aplicação do sebo com chapelona.................................159

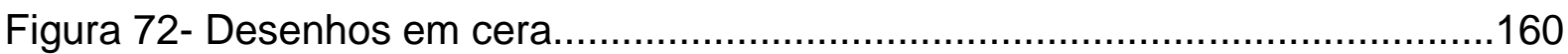

Figura 73- Letras e números em cera..........................................................160

Figura 74- Gravação em cera após aplicação do sebo..........................................161

Figura 75- Finalizada a gravação..................................................................161

Figura 76- Barro copiador - luto, aplicado sobre a gravação.................................162

Figura 77- Visão externa do molde das manilhas em cera....................................164

Figura 78- Visão interna do molde das manilhas em cera....................................164

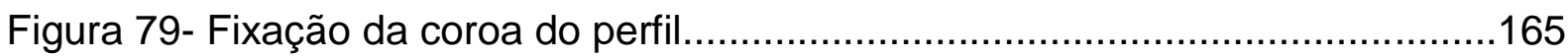

Figura 80- Cobertura do perfil, após o luto, de argila fabricada/ $1^{\text {a }}$ fêmea.................166

Figura 81- Buraco onde são colocados os perfis para fundição............................166

Figura 82- Sisal utilizado nas duas camisas/fêmeas...........................................167

Figura 83- Abertura dos furos nas manilhas..................................................168

Figura 84- Cobertura do perfil para reforço da $1^{\text {a }}$ fêmea, formação da $2^{\text {a }}$

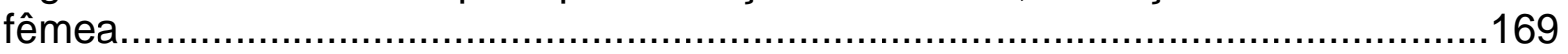

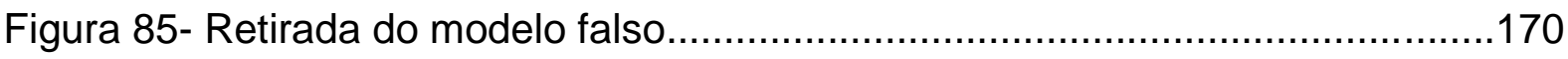

Figura 86- Modelo untado de cinza com leite com grapas.....................................170

Figura 87- Após o leite, a camisa é depositada e o complexo é aquecido..............171

Figura 88- Três orifícios, dois respiros laterais e o central para passagem do bronze.

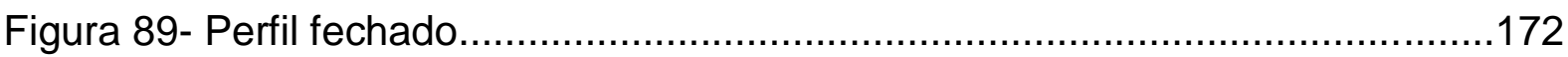

Figura 90- Prensa das formas para serem fundidas.........................................173

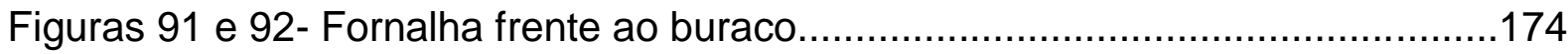


Figura 93- Forno- material quase todo derretido

Figura 94- Ato da fusão, o material escorre pela caneleta....................................176

Figura 95- Etapa de fusão, descida pelas caneletas..........................................177

Figura 96- Canais de escoamento do bronze..................................................177

Figura 97- Sinos fundidos, prontos para serem desenterrados............................179

Figura 98- Sinos fundidos para retirada das fêmeas..........................................179

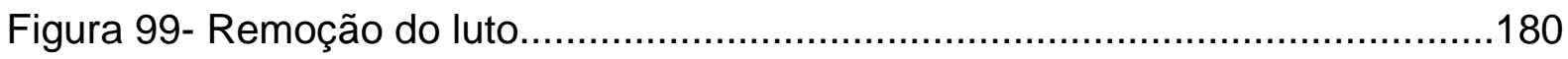

Figura 100- Sino desenformado para retirada do macho......................................180

Figura 101- Desenho do perfil de sino - corte longitudinal..................................181

Figura 102- Sino limpo para polimento- retirada das rebarbas.............................182

Figura 103- Sinos com rebarbas nas manilhas.................................................183

Figura 104- Processo de polimento do sino......................................................183

Figura 105- Polimento do sino em bronze......................................................184

Figura 106- Sinos de $205 \mathrm{~kg}$ (dó), $140 \mathrm{~kg}$ (ré) e $100 \mathrm{~kg}$ (mi) localizadas na Paróquia Imaculada Coração de Maria, em Brasília - DF. 185

Figura 107- Sino de $410 \mathrm{~kg}$ (lá bemol)localizado na Igreja Sagrada Família, em Araranguá - SC 185

Figura 108- Sinos de 85kg (fá) e 60 kg (sol), localizados em Souzas - SP...........186

Figura 109- Sistema de automação para melodias................................................186

Figura 110- Sinos de $85 \mathrm{~kg}$ (fá) e 60 kg (sol), localizados em Souzas - SP...........188

Figura 111- Célula do mapa conceitual do sineiro referente à liga de metais bronze.

Figura 112- Célula de mapa conceitual do sineiro- Luto, barro copiador.................192

Figura 113- Célula de mapa conceitual do sineiro - Argila fabricada......................193

Figura 114- Mapa conceitual geral do ourives William........................................207

Figura 115- Mapa conceitual geral do ourives Álvaro............................................209 


\section{NOTA TÉCNICA}

As citações traduzidas contidas no que diz respeito às obras de Heller (1994); Kozulin (1994); Lefebvre (1947); Leontiev (1983); Marx (1983); Rudniova (2012); Sakharov (1990); Toulmin (1977,1973); Vigotski (2007); Vygotsky (1998) e Vygotski (1997a,1997b,1997c,1997d) são de responsabilidade da autora. Esclareçese, ainda, que o nome de Vigotski foi grafado no texto conforme consta na obra de referência. Ao se referir a ele e não a uma de suas obras, especificamente, adotouse a transliteração correta do russo para o português. 


\section{SUMÁRIO}

APRESENTAÇÃO

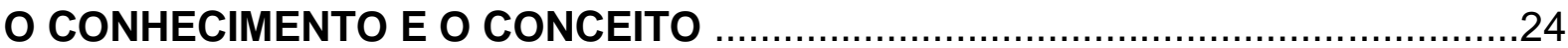

Conhecimento escolar: uma hibridização dos conhecimentos científicos e cotidianos.

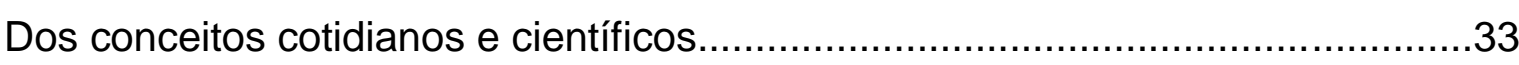

O processo de desenvolvimento do pensamento por conceito.............................42

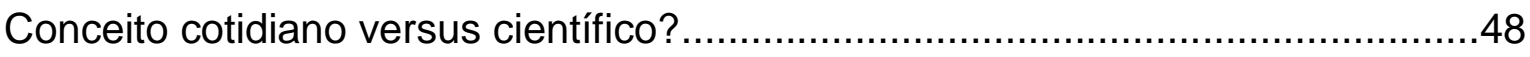

A VIDA COTIDIANA

CIÊNCIA, COTIDIANIDADE E VARIABILIDADE CONCEITUAL...........................76

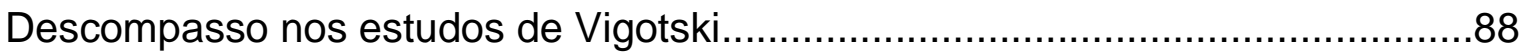

A ATIVIDADE ARTESANAL E O PENSAMENTO CONCEITUAL .........................95

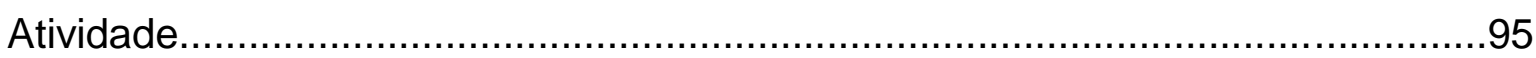

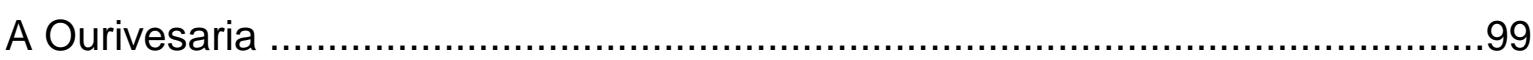

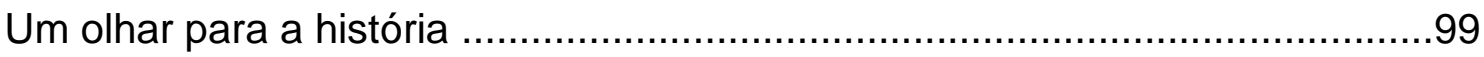

Ourivesaria hoje: informações gerais ....................................................112

A atividade do ourives e o pensamento conceitual ....................................126

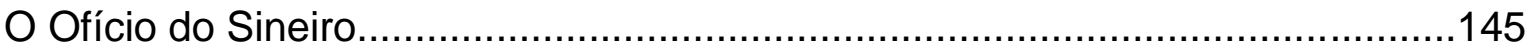

O Sr. José Donizete e seu mestre: um breve relato histórico .........................146

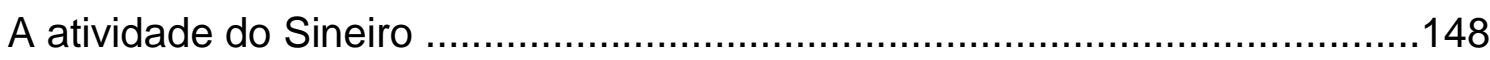

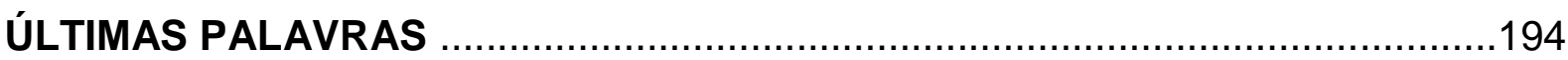

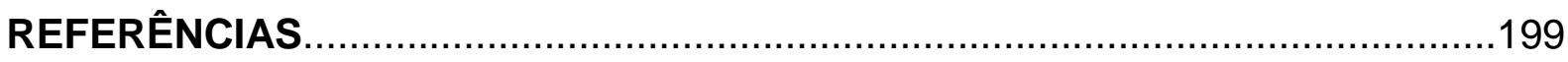

APÊNDICE A - Mapa conceitual geral do ourives William .....................................206

APÊNDICE B - Mapa conceitual geral do ourives Álvaro ....................................208

ANEXO A - Reportagem: Família Lykov......................................................210 


\section{APRESENTAÇÃO}

Durante os anos de exercício profissional como pedagoga, na instituição escolar, tive oportunidade de observar que, no processo de escolarização, a ênfase dada à transmissão de conteúdos e sua repetição pelos estudantes para demonstrar - que aprenderam está desvinculada da atividade de pensar e relacionar logicamente as ideias. Tal prática possibilita apenas o desenvolvimento das funções psíquicas que envolvem principalmente a memorização e a atenção. Ao memorizar o conteúdo, o estudante não pensa por si, fica limitado a repetir o texto sem estabelecer relações entre as ideias e sem refletir criticamente sobre o seu estudo. Aprende a repetir o conteúdo ensinado e, quando muito, a verbalizar a definição de um conceito.

Como uma das instituições a serviço da transmissão do conhecimento científico, a escola sustenta o discurso instituído ideologicamente na estreita relação entre mercado, comunidade científica e política educacional. É com base nessa lógica que o conhecimento científico, para ser ensinado, passa por uma transformação, sendo organizado em conteúdos curriculares por meio de um processo de didatização (LOPES, 1999). Esse conhecimento escolarizado é reverenciado pela comunidade escolar. Ele é apenas repetido com louvor. Como afirma Flusser (2009), quando o texto não é questionado e criticado, ocorre a subserviência.

Concomitantemente, atentei para o fato de que muitas pessoas, apesar de não terem concluído a educação básica, operam de maneira peculiar, correta e, por vezes, sofisticada, com conceitos científicos em suas atividades de ofício. Quando consultadas a respeito da atividade do ofício que exercem, articulam as ideias entre si, bem como apresentam certa sistematização conceitual.

Acrescente-se, ainda, o fato de que, em meu mestrado, fiquei intrigada com os estudos de Vygotski (1997b) a respeito da dinâmica afetiva no trânsito da atividade de pensamento prático para o teórico e vice-versa, caracterizando o movimento da ação no processo de desenvolvimento psíquico. Para ele, inclusive, essa seria a chave para compreender o desenvolvimento atípico. Esses estudos me 
levaram a investigar a respeito do desenvolvimento do pensamento por conceito cotidiano e científico, tratado por Vigotski em sua obra Pensamiento y habla ${ }^{1}$. O conceito cotidiano, segundo ele, origina-se na experiência do dia a dia, de forma assistemática, e o científico desenvolve-se pela instrução formal, estruturando-se em sistemas hierárquicos de generalidade. Ele aponta a superioridade do conceito científico em relação ao cotidiano e diz que ambos se desenvolvem em um processo de contínua interação. A formação dos conceitos científicos estaria ancorada nos cotidianos e seria o uso funcional da palavra o que possibilitaria o desenvolvimento do pensamento por conceito. Como diz,

[...] do ponto de vista psicológico, o significado da palavra [...] não é outra coisa que uma generalização ou um conceito. Generalização e significado da palavra são em essência sinônimos. Toda generalização, toda formação de conceito representa o mais específico, o mais autêntico e o mais indubitável ato de pensamento (2007, p. 426).

Para ele, a formação da consciência reflexiva acontece com o desenvolvimento dos conceitos científicos. À escola caberia a função de propiciar à criança o acesso aos conhecimentos científicos por meio do processo de instrução, de modo a libertá-la das entranhas da cotidianidade. Contudo, os conceitos cotidianos propiciariam as condições necessárias para a vida humana no dia a dia. Vygostki (1997a, 1997b, 1997c) afirma que é no enfrentamento das tensões e conflitos, presentes na vida humana, que se tem as condições para o desenvolvimento da atividade psíquica.

Há aspectos problemáticos no tratamento dado por Vigotski à questão da formação dos conceitos científicos e cotidianos. De um lado, o autor estabelece uma separação entre as duas formas de conceitos, conferindo superioridade ao científico. De outro, faz certa apologia à instrução escolar, o que contradiz sua posição

\footnotetext{
1 Há uma edição dessa obra em português - A Construção do Pensamento e Linguagem, tradução de Paulo Bezerra pela editora Martins Fontes e publicada em 2001. Optou-se pela tradução argentina de Alejandro Ariel González, que, por seu cuidado e respeito ao estilo e originalidade do texto do autor, está mais fiel ao original russo (ver PRESTES, Z. Quando não é quase a mesma coisa: análise de traduções de Lev Semionovitch Vigotski no Brasil, repercussões no campo educacional. Tese de Doutorado. Faculdade de Educação, Universidade de Brasília, 2010).
} 
defendida na obra Psicologia Pedagógica (2003), quando adota uma posição libertária, condenando os modos vigentes de organização escolar.

Para examinar esses dois aspectos indicados é interessante trazer à tona alguns apontamentos de Caruso (2007), apresentados na obra Pensamiento y habla, que permitem apreender alguns aspectos do contexto político, social e cultural vivido por Vigotski, no início do século $\mathrm{XX}$, período pré e pós-Revolução Russa, com a constituição da União Soviética. Na década de 30 do século passado, a situação de Vigotski complicou-se com muitas críticas de outros estudiosos, recebidas por suas ideias consideradas "esquerdistas e trotskistas". Algumas dessas ideias incluíam uma crítica radical à instituição escolar. Para ele, na nova sociedade que se forjava, a tendência seria o desaparecimento dessa instituição, pois a instrução aconteceria imersa na vida concretamente vivida. Essa posição divergia do pensamento oficial do Partido Comunista, que também o criticava. Muitas de suas obras não foram publicadas e outras tantas, censuradas. Segundo Caruso (2007), talvez Vigotski tenha tentado redimir-se de suas posições, apresentando, de algum modo, um exame da importância da instituição escolar para o desenvolvimento do pensamento por conceito científico. Nessa obra, sua posição marxista fica claramente marcada - haja vista a distinção entre conceitos científicos e cotidianos. Daí, talvez, porque tenha encontrado facilidade em publicá-la naquela época.

É exatamente dessa questão que me ocupo no presente trabalho: examinar criticamente a distinção entre conceitos cotidianos e científicos e a supremacia conferida a estes últimos. Pretendo mostrar que o pensamento por conceito desenvolve-se em tipos infinitamente variados de atividades, havendo para cada uma um modo funcional particular de operar com o conceito. Ou seja, pretende-se mostrar que não há um único modo de pensamento por conceito científico que se diferencia de um único modo de pensamento por conceito cotidiano. Ou, em outras palavras, há uma diversidade de modos de pensamento, que não podem ser tratados como duas categorias distintas.

Este trabalho organiza-se em quatro capítulos: no primeiro capítulo, pretendo questionar a separação dos conceitos em científicos e cotidianos, adotada por Vigotski. Para este autor, os conceitos cotidianos originam-se da atividade prática do dia a dia, na relação direta da palavra com o objeto, enquanto que os científicos desenvolvem-se por meio da instrução formal e envolvem a relação semiótica entre palavras. Para proceder à crítica à posição desse autor, analisarei o 
processo de ensino de ciências, bem como a hibridização dos conhecimentos científicos e cotidianos que dá lugar ao aparecimento do conhecimento escolar, com a descontextualização histórica dos conceitos científicos e de sua problemática.

Na sociedade contemporânea, há uma estreita relação entre o Estado, a tecnologia e a prática científica. É atribuído à ciência o poder de reger e de estabelecer os parâmetros desejáveis, ideologicamente, à vida humana. Para ser reconhecido socialmente, o conhecimento necessita da chancela da comunidade científica. Em uma sociedade cientificista, essa prática ideológica traveste os saberes da vida e estabelece que o conhecimento científico deve ser organizado em conteúdos curriculares respaldados pela comunidade científica. Para ser ensinado, ele é extremamente didatizado, isto é, transformado em conteúdos, fragmentados pela regra didática de partir do mais simples para o mais complexo. Ainda, procurase estabelecer uma relação desses conteúdos com o dia a dia do aluno. Trata-se, assim, de um conhecimento escolar, não mais ciência. Cabe destacar que a atividade do escolar é diferente daquela do cientista, assim como ambas são diferentes de outras inúmeras atividades.

Ao distinguir os dois tipos de conceitos, tendo por base a sua gênese (instrução formal, no caso dos científicos e atividade cotidiana, no do outro), essa concepção de Vigotski requer a admissão da ideia de que o conhecimento científico - e também o escolar - estão fora da vida cotidiana. Essa ideia é válida? Para investigá-la, é necessário examinar o que vem a ser conhecimento cotidiano e conhecimento científico.

Assim, o segundo capítulo trata do que vem a ser a vida cotidiana e de algumas de suas acepções e implicações para a ciência moderna e para o estudo do desenvolvimento do pensamento por conceito. Nele, analisarei o cotidiano como espaço de enfrentamento de tensões e conflitos presentes na vida humana, o seu caráter criador e o seu caráter repetitivo em ações do dia a dia, no trabalho e na convivência social.

Para esse exame, focalizarei a concepção helleriana de cotidiano, que compreende a vida do homem em seu pragmatismo e heterogeneidade, e em que 0 pensamento e ação constituem uma unidade imediata. Nessa perspectiva, o pensar cotidiano caracteriza-se por ideias fragmentadas e juízos de orientação social, guiados pela avaliação probabilística e por estereótipos, ressaltando-se a importância da suspensão da cotidianidade por meio da ciência e da arte, para que 
aconteça a passagem do homem particular ao homem genérico. Em contraposição a essas ideias, apresento pontos de vista como os de Lefebvre $(1947,1991)$, que, apesar de admitir o caráter repetitivo nas ações do dia a dia, no trabalho e na convivência social, ressalta o seu caráter criador e afirma que é na vida cotidiana que se encontra o núcleo racional da práxis. Ele argumenta que, em atividades criadoras, sejam da ciência ou da arte, o caráter repetitivo também se faz presente. Acrescenta, ainda, que a atividade criadora do mundo humano é constante e cotidiana e alerta para o fato de que muitas interpretações do cotidiano são distorcidas e devaneadoras, retratos do desenlace com a vida, vãs abstrações de furtos ideológicos. Para ele, na vida não há uma fronteira abissal entre a ação e o pensamento, assim como no conhecimento não há uma demarcação absoluta entre a teoria e a prática.

O terceiro capítulo versa sobre o que vem a ser a ciência e suas implicações com o modo de vida da sociedade contemporânea, guiada por valores econômicos, científicos e tecnológicos. Analisarei a perpetuação da crença na ideia de a ciência tudo poder explicar e justificar conforme seus próprios parâmetros. Para essa discussão, trago o filósofo Toulmin² (1977), que compreende a ciência como uma população histórica de conceitos e teorias logicamente independentes, cada um dos quais com sua história, sua estrutura e suas próprias implicações. Para ele, o desenvolvimento histórico do conhecimento e da compreensão humana acontece na vida cotidiana. Os conceitos são organizados em sistemas e as mudanças históricas influem sobre a autoridade intelectual deles. Segundo o seu pensamento, a prática de categorizar tipos de conhecimentos, classificando alguns como racionais ou científicos e outros como supersticiosos ou tolos está calcada numa autoridade intelectual supostamente legitimada por métodos científicos de investigação. O autor também afirma que a estrutura dos conceitos cotidianos constitui a trama comum da vida e do pensamento ordinário, representando um plano particularmente estável e bem adaptado do desenvolvimento das atividades intelectuais. Ele ressalta que é possível reinterpretar as invariâncias do pensamento e da linguagem, de modo a eliminar a dicotomia tradicional entre conceitos a priori e conceitos empíricos com

\footnotetext{
${ }^{2}$ Stephen Toulmin Edelston nasceu em Londres em 1922, foi educado na Universidade de Cambridge, obteve seu doutorado em filosofia em 1948 e foi discípulo de Wittgenstein.
} 
bases filosóficas e epistemológicas muito diferentes. Segundo suas ideias, a ciência não se desenvolve fora do cotidiano.

Seguindo linha similar de pensamento, apresentado no terceiro capítulo, Flusser (1979) afirma que a ciência é atividade humana, em que o homem engajado está imerso no mundo. Portanto, homem e ciência não são entidades separadas; ambos relacionam-se na realidade concreta. A crença na atitude ética e ideologicamente neutra do cientista, para esse autor, é fruto de alienação do estarno-mundo, pois o homem imerso no mundo e comprometido com a sua realidade não é alguém puro e neutro. Portanto, o conhecimento não é fruto do transcendente, mas um dos aspectos do estar-no-mundo humano.

No quarto capítulo, apresento um estudo de duas atividades artesanais, a do ourives e a do sineiro, com vistas a analisar o modo como eles operam o pensamento por conceito no seu ofício. Escolhi as duas atividades por serem ofícios artesanais não escolarizados, cuja aprendizagem acontece na relação tutorial de um aprendiz com o seu mestre. Acompanhei a atividade diária de dois ourives na produção e no conserto de peças em prata e em ouro, em alguns encontros, totalizando 18 horas e 50 minutos de conversa e observação. Para conhecer a atividade de fabricar sinos, fui até Uberaba, em Minas Gerais, por duas vezes, totalizando 14 horas de observação e entrevistas. Não houve um roteiro de perguntas organizado previamente, posto que, no desenrolar da observação in loco, as perguntas foram apresentadas com o intuito de esclarecer dúvidas, de compreender o ofício e os procedimentos adotados. As entrevistas foram gravadas e transcritas para análise mais detalhada. Foi permitido, tanto pelos ourives como pelo sineiro, fotografar suas oficinas. No caso do sineiro, muitas imagens foram cedidas por ele, pois em nossos encontros pude conhecer apenas algumas das etapas de todo o processo de fabrico dos sinos.

Concluída a etapa de realização de entrevistas e das observações, as informações referentes ao sineiro foram detalhadas em um texto explicativo. Foram também elaborados mapas conceituais com vistas a reconhecer as relações conceituais estabelecidas por ele na realização de sua atividade. Os dados a respeito da atividade dos ourives também foram organizados em mapas conceituais.

O mapa conceitual foi desenvolvido por Novak, em 1972, na Universidade de Cornell, nos Estados Unidos da América, dentro do programa de pesquisa que se 
baseava na psicologia da aprendizagem de Ausubel $^{3}$ e tinha como proposta entender as mudanças ocorridas no modo como as crianças compreendiam a ciência. No processo de acompanhamento dessas crianças, Novak e seus colegas pesquisadores enfrentaram dificuldades em identificar mudanças específicas, ocorridas no processo de compreensão de conceitos científicos por parte delas. Ao examinarem as entrevistas transcritas, elencaram os conceitos apresentados por elas e, diante da necessidade de encontrar uma forma de representar a sua compreensão conceitual, surgiu a ideia de organizar os conceitos e relacioná-los em um diagrama. À medida que foi testado em pesquisas, o mapa conceitual passou por ajustes, com o propósito de ser utilizado, também, por alunos e professores no processo de ensino e aprendizagem (NOVAK e CAÑAS, 2010). Para ilustrar, a Figura 1 mostra um mapa conceitual sobre as razões da existência das estações do ano.

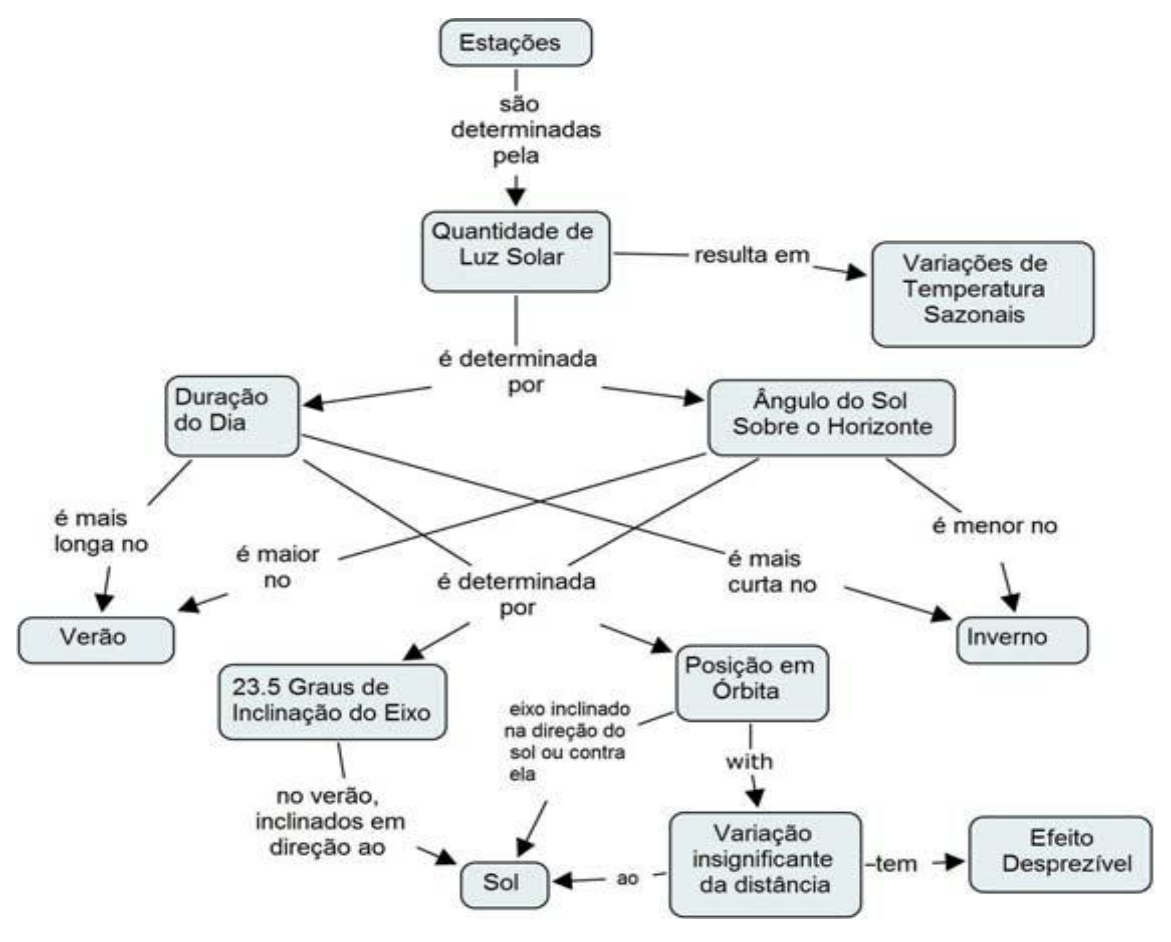

Figura 1. Um exemplar de mapa conceitual sobre as razões da existência das estações do ano.

Fonte: NOVAK,J.D. e CAÑAS,A.J. A teoria subjacente aos mapas conceituais e como elaborá-los e usá-los. Práxis Educativa. Ponta Grossa, v.5, n.1, p. 9-29, jan.-jun. 2010.

\footnotetext{
${ }^{3}$ David Ausubel nasceu em 25 de outubro de 1918. Foi um grande psicólogo da educação norte-americana. Sua teoria da aprendizagem objetiva facilitar a aprendizagem do aluno. Para ele, é no processo da aprendizagem significativa que 0 significado lógico do material de aprendizagem, uma nova informação, se transforma em significado psicológico para 0 aprendiz (MOREIRA,1999).
} 
Trata-se de uma ferramenta gráfica que possibilita organizar e representar o conhecimento em diagramas de significados, de relações entre conceitos. É um instrumento que evidencia os significados atribuídos aos conceitos e as articulações entre eles no contexto de um corpo de conhecimento. Os conceitos mais inclusivos e gerais ficam dispostos no topo e os mais específicos e menos gerais, hierarquicamente abaixo. Os conceitos elencados são dispostos e ligados por frases ou palavras que indicam como eles se relacionam dentro do domínio do conhecimento (NOVAK e CAÑAS, 2010).

Construídas as primeiras versões dos mapas conceituais para cada um dos ourives, contendo todas as informações obtidas, elas foram submetidas à apreciação dos mesmos e corrigidas no que foi necessário. De posse das versões finais, passei a examiná-los, detidamente, buscando identificar indicadores dos modos de pensamento com que os profissionais operam.

Após o primeiro encontro com o sineiro, procurei discorrer e descrever cada etapa do processo de fabricação. Para cada etapa, procurei selecionar imagens que facilitassem a compreensão da complexidade de detalhes que envolvem o fabrico de um sino. Organizadas as informações e descritas todas as etapas, examinei detalhadamente cada uma e marquei um segundo encontro para checagem e esclarecimento de dúvidas. Como a feitura de sinos é uma atividade muito complexa, procurei identificar indicadores que denotassem os modos de operar o pensamento na realização da atividade de fabricação de sinos. Para tal, foram elaborados dois mapas conceituais que, contudo, não foram apresentados a ele, como no caso dos ourives.

Por fim, no quinto capítulo, teço um exame crítico conclusivo a respeito das questões já mencionadas nos capítulos anteriores, as implicações e os desdobramentos deste trabalho para a educação, em especial para o ensino de ciências. 


\section{O CONHECIMENTO E O CONCEITO}

Neste capítulo, pretende-se questionar a separação dos conceitos em científicos e cotidianos, adotada por Vigotski. Em um primeiro momento, examina-se a articulação entre os conhecimentos científico, cotidiano e escolar no processo de ensino, considerando sua relação com os conceitos comumente denominados de científicos e comuns ou cotidianos. Para essa análise, tomou-se como exemplo o ensino de ciências. Em um segundo momento, apresenta-se o estudo realizado por Vigotski, que se destaca dos demais teóricos por sua minuciosa e profunda investigação a respeito do processo de formação e desenvolvimento dos conceitos por ele denominados científicos e cotidianos ou espontâneos.

\section{Conhecimento escolar: uma hibridização dos conhecimentos científicos e cotidianos.}

Em uma sociedade escolarizada e cientificista, a educação é equiparada à quantidade de anos de escola. Esta exerce a incumbência de conduzir as crianças e os jovens a percorrerem o portal do conhecimento e do saber, de forma a torná-los úteis e produtivos socialmente. Vale fazer, aqui, uma pequena digressão com o propósito de esclarecer o que vem a ser uma sociedade escolarizada e cientificista.

A sociedade cientificista moderna está calcada na estreita relação entre a ciência, a tecnologia e a política de Estado. A imagem de uma ciência eticamente neutra é perpetuada no ideário social como algo isento de qualquer influência ideológica e que tudo explica e comprova empiricamente. A crença das pessoas na ideia de que a ciência é capaz de responder e orientar a respeito dos conflitos e dramas da vida promove a submissão às descobertas científicas e às informações 
divulgadas pelas mídias. É conferido à ciência o poder de autoridade suprema na sociedade.

Essa prática social de servir aos padrões estipulados pela ciência não é por acaso. Flusser alerta para o fato de que: "A atitude eticamente $\mathrm{e}$ ideologicamente neutra do cientista puro é pretensão, produto de alienação de o [sic] concreto estar-no-mundo" (1979, p.166). Nas instituições sociais e em programas de governo, é perceptível o enlace ideológico da ciência com as políticas de Estado. Seguindo essa linha de pensamento, Bartholo (1992, p.29) diz:

\begin{abstract}
$\mathrm{Na}$ modernidade industrializada as relações entre a prática científicotecnológica e o Estado sofrem importantes redefinições. Ao Estado moderno não interessa mais o pensador contemplativo e sim a vinculação do pensamento científico à ação política institucionalizada por seus organismos de governo. Engendra-se assim uma relação de tipo novo entre o Estado e o cidadão, onde emerge como mediadora uma prática política cientifizada. Ciência e política amalgamam-se numa nova síntese ordenadora de coesão social, onde a política se baseia na ciência para justificar suas estratégias, e a ciência veicula através da política sua concepção de mundo.
\end{abstract}

Dessa forma, ao fornecer resultados de pesquisas, dados estatísticos e subsídios para o fomento de programas de governo, bem como ao atender às exigências de mercado, a ciência exerce certo poder de controle sobre a vida das pessoas. Essa prática sustenta uma ideologia cientificista que pode ser verificada nos discursos mascarados por termos científicos com o propósito de validar informações e ideias do senso comum, que recebem uma roupagem científica, para adquirirem o status social desejado e inquestionável. Além disso, a ciência é mitificada, por ser interpretada como detentora de uma verdade absoluta. Seu aspecto provisório e relativo como obra humana é desconsiderado (LOPES, 1999).

Uma das instituições sociais que perpetua essa ideologia é a escola, que traz em seu discurso a promessa de preparar a criança e o jovem para a vida e de formá-los cidadãos críticos e adaptados aos padrões sociais. A escola serve a programas governamentais e à lógica de mercado; para tal está regulamentada e amparada por lei. Sob o jugo da lei, as pessoas são obrigadas a cumprir anos de escolarização, tendo como meta a aquisição de certificados como garantia de 
atender às exigências mercadológicas. Assim, ao perpetuar os valores ideológicos da aliança Estado-ciência-mercado, a escola cumpre sua responsabilidade de transmitir o conhecimento científico (ILLICH, 1986). O processo de escolarização, na sociedade contemporânea, assume papel de principal condição para o alcance de um futuro promissor e de uma vida digna. Na sociedade escolarizada, confundem-se anos de escola com boa formação, ensino com aprendizagem, obtenção de graus com educação, diploma com competência e fluência no falar com capacidade de dizer algo novo, como já anunciava Ivan Illich, na década de 1970.

Durante os anos escolares, o conhecimento científico é tratado como verdade incontestável e transformado, didaticamente, para que possa ser ensinável e acessível à compreensão do estudante. Ao ser escolarizado, é organizado e reestruturado em disciplinas. Um currículo mínimo é estabelecido em conformidade a uma política de educação do Estado. É um conhecimento apresentado ao estudante como algo pronto, inquestionável, que deve ser repetido e memorizado, diferentemente da postura investigativa que a ciência requer, ao problematizar e buscar respostas sobre as questões que permeiam a vida humana. Confunde-se 0 pensar por conceito científico com verbalizar e repetir sua definição.

No processo de escolarização dos conhecimentos científicos e cotidianos presentes na cultura, são produzidos textos didatizados, planejados pedagogicamente de modo a facilitar ao máximo a sua leitura e compreensão. Esses textos didáticos são adotados como verdades que devem ser repetidas. Essa prática reflete a postura passiva e de adoração ao texto, que Flusser (2009) denominou de "textolatria", atitude obediente diante do texto, a ponto de não se vislumbrar a possibilidade de criticá-lo. O texto é concebido como algo inquestionável e não passível de contestação, cabendo apenas ao estudante a subserviência plena e a sua reprodução.

É no âmbito da própria ciência que se procuram os critérios para selecionar os conhecimentos que se tornarão acessíveis na escola. Tal triagem está comprometida ideologicamente e visa a intervir na relação indivíduo-cultura, que tem por base objetivos pré-estabelecidos, calcados na relação entre o mercado, a comunidade científica e a política educacional (LOPES, 1999).

Em trabalhos publicados sobre o ensino de diferentes áreas do conhecimento, verifica-se que a questão da contextualização do conhecimento científico está presente na prática pedagógica do professor, que visa a estabelecer a 
relação do conteúdo a ser ensinado com a experiência diária dos estudantes. Silva (1990) defende a ideia de que, no ensino de Química, deve-se partir do conceito concreto para os abstratos, de modo que o estudante realize inicialmente operações intelectuais mais ligadas à experiência prática, para, posteriormente, realizar operações mais abstratas. Assim, um estudante poderá compreender um conceito abstrato pelas ligações que esse apresenta com outros conceitos, que estão mais relacionados à experiência sensorial. Contudo, Silva (1990) alerta que, ao se buscar concretizar conceitos de natureza abstrata sem o estabelecimento de relações conceituais, inadvertidamente, acaba-se por propiciar o aprendizado distorcido da ciência.

No ensino da Geografia escolar, Zanatta (2005) analisa a questão da contextualização do conhecimento com o enfoque no contato direto do estudante com a natureza, quando este observa a paisagem, mediante o trabalho de campo, com olhar crítico para a realidade local. Ela salienta que essa prática pedagógica não é recente. No século $\mathrm{XIX}$, as contribuições do pensamento pestalozziano ${ }^{4}$ marcaram a proposta metodológica de ensino da Geografia no sistema escolar alemão. Conforme a concepção pestalozziana, ensinar requereria gradualismo do conhecimento, isto é, o professor deveria prosseguir, gradualmente, do particular para o geral, do concreto experienciado para o racional, chegando aos conceitos abstratos. Para isso, o professor deveria buscar o material de estudo no contexto da situação de vida do estudante. Essa proposta metodológica para o ensino da Geografia repercutiu, no Brasil, nas demais áreas de ensino.

Do mesmo modo, Pinho Alves (2000) discute a necessidade de relacionar os conteúdos de Física com a cultura e o cotidiano dos estudantes. Segundo ele, o professor precisa estar atento ao fato de que o ensino dos conceitos de Física tem de estar atrelado à resolução de problemas. Para tal, relacionam-se os conceitos

\footnotetext{
4 Johann Heinrich Pestalozzi (1746-1827), educador suíço, nasceu em Zurich. Foi influenciado pelo pensamento de Rousseau e por alguns aspectos do movimento romântico, como o amor pela natureza e a concepção organicista. Suas obras principais são Leonardo e Gertrudes (1781) e Como Gertrudes instrui seus filhos (1801). Para ele, a escola tinha uma função social, a de difundir o saber universal a todas as classes sociais como condição para se alcançar a dignidade humana. Em seu método de ensino, estabeleceu alguns princípios, como: partir do conhecido ao desconhecido; do concreto ao abstrato, ou do particular ao geral; da visão intuitiva à compreensão geral, por meio de uma associação natural com outros elementos e, finalmente, reunir no todo orgânico de cada consciência humana os pontos de vista alcançados. O fundamental, para ele, não era ensinar determinados conhecimentos, mas desenvolver a capacidade de percepção e observação dos alunos. Ou seja, acreditava que os conhecimentos deveriam estar relacionados a atividades práticas, calcados em uma educação moral e religiosa, pois constituem a base da formação do homem. Para ele, a educação intelectual transforma-se em um espectro quando não é vivificada e vinculada ao trabalho (ZANATTA,2005).
} 
científicos com o contexto do dia a dia. Ele destaca, ainda, que decodificar a complexidade conceitual possibilita a compreensão de um conceito da Física.

Esses três autores exemplificam uma preocupação com o ensino da ciência. Um aspecto comum entre eles é a ideia de que é preciso contextualizar o conhecimento científico, prosseguir do conceito cotidiano ao científico, ou seja, aproximar este do conhecimento do dia a dia e torná-lo, assim, entendível. No processo de ensino, os conceitos pertencentes ao mundo das ciências são relacionados aos cotidianos, conceitos estes que são considerados limitados à rotina do dia a dia. Talvez, essa prática se valha da compreensão de que a ciência esteja distante da cotidianidade da vida. Percebe-se, na literatura, um viés valorativo na interpretação dada a essas categorias conceituais, como se o conhecimento cotidiano fosse inferior ao científico. Tal concepção perpetua-se no espaço de sala de aula.

Nas instituições escolares, adotam-se estratégias pedagógicas para estabelecer relações diretas entre o cotidiano e a ciência. Para Lopes (1999), nesse processo de contextualização deve-se considerar que os modos de relações sociais encontram-se na sua cotidianidade. A autora destaca que o conhecimento cotidiano possui caráter pragmático, pois é produzido na rotina diária que propicia as condições de vida e de sobrevivência das pessoas. Ele está atrelado a contextos culturais diferenciados e é passado de geração em geração.

O conhecimento validado pela comunidade científica é traduzido para a cultura escolar, segundo Mortimer (1997), por meio da transposição didática, que consiste em um processo de estruturação e organização dos conteúdos, por meio de mecanismos didáticos, técnicas e estratégias pedagógicas. Trata-se de um conhecimento diferente do de sua origem, isto é, do conhecimento científico, que comporá o currículo da área de conhecimento. Para esse autor, apesar do aprendizado da linguagem científica ser importante, com os nomes e grupos nominais diferenciados, é por meio da linguagem cotidiana que o professor e seus estudantes dão sentido ao processo de aprender ciência. Mortimer (2010, p.204) assim diz: "correspondente a essa apropriação gradual de significados há a possibilidade da construção de hibridizações entre as linguagens científica e cotidiana". Enquanto a linguagem cotidiana é automática, dinâmica e próxima da fala espontânea, a científica se aproxima da linguagem escrita, ou seja, exige estruturação dos termos utilizados. Os acontecimentos são congelados por um 
processo de nominalização, em que grupos nominais são ligados por verbos que exprimem relações entre esses processos. A estrutura conceitual exibe termos carregados de significados interligados (MORTIMER, 2010).

Ele argumenta, ainda, que com a transposição didática procura-se estabelecer uma relação entre os conceitos científicos, o conteúdo e o contexto do dia a dia do estudante. O professor coloca lado a lado as concepções cotidianas a respeito do conteúdo estudado, vinculando a ele os científicos. Origina-se, então, um perfil conceitual com vistas a demonstrar uma forma de ver e representar o mundo, bem como de utilizá-lo em contextos diferenciados. Assim, a realidade pode ser entendida sob outras perspectivas (MORTIMER, 1997, p.184).

Ter consciência de um conceito implica aplicar a idéia científica em contextos em que ela é apropriada, seja em atividade intelectual ou prática, e ao mesmo tempo, preservar modos de pensar e falar distintos do científico nas situações em que se mostrem pragmaticamente apropriados. Trata-se de uma coexistência entre diferentes modos de pensar e falar.

Com a visão de que o conhecimento produzido pela comunidade científica é superior a qualquer outra forma de conhecimento, o professor apoia-se nos conceitos cotidianos a fim de expor os científicos, entendendo que o conhecimento científico deva suplantar o cotidiano. Entretanto, Lopes (1999) destaca que ambos os conhecimentos são históricos, fazem parte da cultura, interagem e são propagados por gerações sucessivas. O científico compreende um modo de conhecimento, dentre outros tantos e, portanto, não há a necessidade de hierarquização.

[...] o conhecimento científico rompe com os princípios e formas de pensar cotidianos, com os quais o conhecimento escolar precisa dialogar, o que nos exige compreender como essas inter-relações [...] podem acontecer (LOPES, 1999, p.20). 
Os conteúdos escolares são ancorados em conceitos cotidianos e organizados didaticamente de forma que o professor possa transmitir um conhecimento que acredita ser científico. A transposição altera a estrutura textual da linguagem científica para torná-la acessível ao estudante, ou seja, transforma-a em um texto didático, com uma linguagem própria em que os conceitos científicos sofrem um rearranjo em seus sistemas (LOPES, 1999). Eles são transformados em produto de conteúdo escolar a ser consumido por meio dos livros didáticos pelos estudantes.

Em sua pesquisa sobre o ensino de conceitos matemáticos no ensino fundamental, Pavanello (2004) aponta que o processo de escolarização do conhecimento científico transformou-se em uma caricatura formalizada e distante da ciência, dificultando, assim, a aproximação do estudante ao conhecimento científico. Ela observou também que, em textos didáticos, muitos dos conceitos que deveriam explicar um fenômeno científico são termos e expressões do dia a dia, que acabam por modificar, simplificar e comprometer a abrangência do conceito científico. Esse fato passa despercebido por muitos professores e autores de livros didáticos e é perpetuado no processo de ensino. Destaca, ainda, que o conhecimento científico e o cotidiano, apesar de possuírem epistemologias distintas e atenderem a finalidades diferenciadas, podem coexistir, atendendo a necessidades e objetivos diversificados. Não precisam, assim, sofrer deformações.

Essas reflexões não são novas. No final da década de 1980, foram realizados estudos a respeito do ensino de conceitos em Química, mais especificamente, sobre o conceito de substância e matéria. Os autores - Silva et al.(1986), Tolentino et al.(1986) e Rocha-Filho,R.C. et al. (1988) - verificaram que são apresentados aos alunos do ensino médio conceitos cotidianos como sendo científicos, fora das relações interconceituais de subordinação, supraordenação e coordenação. Ou seja, são apresentados fora do sistema hierárquico conceitual. Além de confundir e distorcer a compreensão dos conceitos científicos, essa prática docente não possibilita as condições necessárias para o desenvolvimento do pensamento categorial. Nos dias atuais, essa estratégia de ensino perdura e continua despercebida pelos professores em sala de aula.

A didatização exacerbada do conhecimento científico com a adoção de analogias e metáforas equivocadas leva o estudante a crer que haja um continuísmo entre o conhecimento comum e o científico, descaracterizando o propósito da 
ciência e dificultando, assim, a sua compreensão. No ensino de ciências, ao se deslocar um elemento do sistema conceitual, tornando-o conteúdo de estudo, sua natureza conceitual é alterada, ou seja, são retiradas do conceito científico sua problemática e sua história. O sistema conceitual caracteriza-se pelas relações lógicas de coordenação e subordinação entre os conceitos. Ao transformar o conceito em conteúdo, o ensino privilegia o resultado e não o curso de investigação de um fenômeno ou problema que levou à elaboração do sistema conceitual. Por não propiciar o enfrentamento da problemática da ciência, da linguagem formal e do raciocínio formalizado, diante das questões e dos fenômenos implicados no estudo, a escola promove a banalização das relações estabelecidas entre o conhecimento cotidiano e as ciências (LOPES, 1999).

[...] Essa perspectiva termina por se transformar em uma falsa valorização do conhecimento cotidiano. $\mathrm{Na}$ perspectiva descontinuísta não há conhecimentos "melhores" ou "piores", mas conhecimentos diferentes, com racionalidades distintas, aplicadas a instâncias de realidade distintas (LOPES, 1999, p.120).

Uma das características marcantes do conhecimento científico está em sua sistematização, nas relações lógicas entre os conceitos e no seu desenvolvimento por meio de um método de investigação (DOMINGUINI, 2008). Outra particularidade é que "mesmo amparado pela observação e pela experimentação, pode ser contestado a todo momento, perdendo sua suposta veracidade" (SOUSA; ECHEVERRIA; COSTA, 2008, s/n). Não se pode deixar de mencionar que, atualmente, o conhecimento científico pode estar calcado em deduções teóricas, como acontece com a mecânica e a física quântica. Vigotski (2004, p.277) alertava para o fato de que "[...] constitui um grave erro pensar que a ciência só pode estudar o que nos mostra a experiência direta". Já o conhecimento escolar não tem bases epistemológicas próprias. Ele se constitui no encontro entre o conhecimento científico e o cotidiano, e possui outra configuração conceitual. É substancialmente diferente da ciência na qual se baseia.

Se ocorre uma hibridização da linguagem científica com a cotidiana no conhecimento escolar, como propõe Mortimer (1997, 2010), então, o corpo 
conceitual que o constitui também é híbrido. Tal fato ratifica a ideia de que o conhecimento escolar não é ciência.

Lopes (1999) afirma que o conhecimento escolar apresenta um corpo de conceitos relacionados com a vida diária que se aproximam do conhecimento científico, embora parcamente e que, portanto, não é um conhecimento que retrata fielmente a ciência. A transposição do conceito científico para o contexto escolar nem sempre chega a caracterizar um erro conceitual, apesar do distanciamento desse conhecimento em relação ao produzido pela comunidade científica e, de muitas vezes, ser deformado.

Dominguini (2008) alerta para o fato de que o processo de escolarização do conhecimento desloca-o no espaço e no tempo e torna os conceitos objeto de ensino. Os conceitos científicos são transformados em conteúdos desarticulados que o professor, para suprir o hiato com a ciência, procura relacionar com os eventos do dia a dia, atribuindo-Ihes um tom utilitário. Ressalta, ainda, que há o risco de perder o contexto histórico dos trabalhos desenvolvidos pelos cientistas, a dimensão de suas análises, observações e as correlações conceituais estabelecidas nos estudos científicos.

Por trás da prática pedagógica de transposição didática está a lógica utilitarista: tudo deve servir para alguma coisa. Essa lógica é materializada pelo livro didático, que é ainda material de referência para muitos professores e estudantes. É um manual que serve a uma política de educação, atendendo a um currículo pensado e estruturado em conteúdos que apresentam ideias simplistas e reduzidas a respeito de conceitos elaborados pela ciência. Além do fato de o conteúdo escolar ser, muitas vezes, travestido de científico, a questão que merece ser analisada é a diferença entre a atividade do cientista - que em seus estudos procura representar a realidade em conceitos, na busca de respostas diante dos eventos da vida e da própria problematização do conhecimento - e a atividade escolar, que se caracteriza pela repetição do conhecimento entendido como algo pronto e concluído. Isso independe de o conceito científico receber ou não alterações e ter se transformado em conteúdo. Em diferentes atividades, as pessoas se posicionam e se relacionam com o conhecimento de forma variada. 


\section{Dos conceitos cotidianos e científicos}

Em seus estudos sobre o desenvolvimento do pensamento e da fala, Vigotski (2007) estabeleceu uma diferenciação do pensamento verbal em conceitos científicos, ou verdadeiros e conceitos cotidianos.

Ele afirmou que toda palavra é uma generalização e que o conceito é um ato de generalização que se desenvolve. Portanto, os significados das palavras desenvolvem-se no trânsito de uma estrutura de generalização a outra. A formação dos conceitos, tanto cotidianos como científicos, acontece na atividade coletiva, ou seja, nas condições propiciadas pela convivência social e pelo acesso à cultura. $\mathrm{A}$ generalização não se restringiria a ressaltar os traços comuns das realidades inscritas no conceito, mas a revelar os vínculos e as relações estabelecidas entre conceitos, sejam eles da vivência direta da pessoa ou não (VYGOTSKI, 1997b).

Para ele, quando a criança descobre que cada objeto tem um nome, inicia-se o desenvolvimento do significado da palavra, dos conceitos cotidianos, que são formados no curso da atividade prática da vida. Com base em suas pesquisas, Vigotski (2007) afirmou que o desenvolvimento dos conceitos cotidianos acontece em três momentos de vida da pessoa, conforme seu enraizamento cultural: o primeiro, denominado sincrético, caracteriza-se pelo agrupamento desordenado de objetos sem relações internas entre eles; o significado da palavra é difuso.

O segundo momento compreende o pensamento por complexo, no qual predomina a forma de pensamento que estabelece vínculos e relações entre diferentes impressões concretas; os conceitos estão unidos por conexões objetivas dos objetos agrupados. Esse estágio é desmembrado em cinco momentos de desenvolvimento: o complexo associativo, em que, como o próprio nome indica, a criança estabelece alguma relação com atributos que observa no objeto; o complexo coleção, que se caracteriza pelo agrupamento de diferentes objetos com base em algum atributo que os une, apesar das partes serem heterogêneas; o complexo em cadeia, em que a criança elege um princípio que propiciará a associação sequencial dos objetos; o complexo difuso, que é quando a criança une distintos objetos associativamente por um atributo indefinido, não verificável na prática; e o pseudoconceito, que compreende o momento em que o pensamento da criança se 
assemelha superficialmente ao do adulto em atividade intelectual, pois a natureza psicológica do conceito é completamente distinta.

Por fim, o terceiro estágio de desenvolvimento dos conceitos cotidianos consiste na formação dos pré-conceitos. Dentre esses, o principal grupo é o dos conceitos potenciais, que compreende uma formação pré-intelectual. A criança grupa os objetos por um único critério presente em todos eles. Esse agrupamento não se dá por um processo lógico, mas sob critérios de ordem prática.

Pode-se dizer que "o pensamento por complexo desenvolve as estruturas de generalização e o conceito potencial, as de abstração, ambas necessárias para que se atinja [...] o pensamento por conceitos verdadeiros" (TUNES, 2000, p.43).

Para chegar a essa diferenciação, Vigotski (2007) realizou, em parceria com Leonid Sakharov (1990), no Instituto de Psicologia Experimental, experimentos com o método funcional de dupla estimulação:

A essência desse método consiste em observar o desenvolvimento e a atividade das funções psíquicas superiores com ajuda de duas séries de estímulos, cada uma das quais desempenha um papel diferente com respeito ao comportamento da pessoa submetida à prova. Uma delas funciona como objeto ao qual está dirigida a atividade do sujeito e a outra atua como signos com ajuda dos quais esta atividade se organiza (VIGOTSKI, 2007,p.182).

Os dois estímulos compreendem a propriedade física das peças - figuras geométricas de madeira com tamanho, forma e altura variados, nas cores verde, branca, azul, vermelha e amarela, e as quatro palavras sem sentido escritas no verso (bik, tsev, lag, gur) ${ }^{5}$, conforme verifica-se nas peças da Figura 2.

\footnotetext{
${ }^{5}$ As quatro palavras utilizadas por Vigotski no experimento não são mencionadas no texto original em russo. No livro Pensamiento y Habla, traduzido por Alejandro Ariel González e publicado em 2007, há uma nota de rodapé (p.182) que menciona quatro palavras (mur, cev, bik, lag), com base no trabalho publicado por Jakob Kasanin e Eugenia Hanfmann (1942). Com o intuito de checar a informação buscaram-se outras referências. Na obra $A$ Construção do Pensamento e Linguagem, tradução de Paulo Bezerra e publicada em 2001, verifica-se que a descrição do experimento não está em acordo com o original de Vigotski e as palavras não são mencionadas. Na palestra de Sakharov(1990) Methods for investigating concepts, proferida no Congresso Pedológico em Moscou, em 1928, traduzida por Michel Vale, em 1990, são mencionadas outras quatro palavras (bat,dek,rots,mup). Para elucidar a divergência na tradução, contou-se com a colaboração da Profa. Dra. Zoia Prestes, tradutora de russo e estudiosa da Psicologia Soviética, que gentilmente cedeu as imagens do material utilizado por Vigotski, disponível no museu do Instituto de Psicologia Lev Vigotski, fotografado em 2007 quando em visita à Instituição.
} 


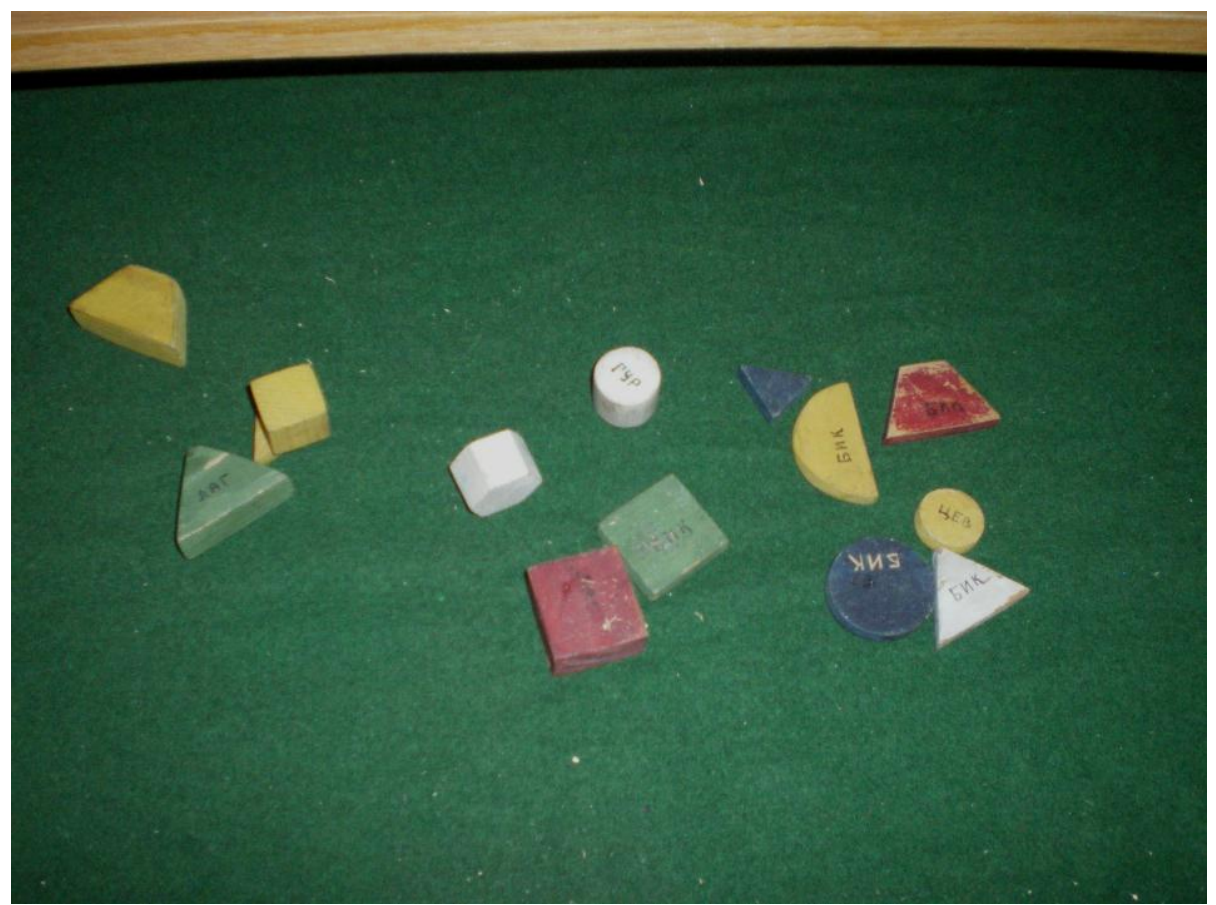

Figura 2. Peças originais utilizadas por Vigotski em seus experimentos com o método funcional de dupla estimulação.

Fonte: Museu Vigotski no Instituto de Psicologia Vigotski. (foto original colorida)

Cada um dos estímulos desempenha um papel diferente no comportamento da pessoa submetida ao experimento, ou seja, um funciona como objeto dirigido à atividade e o outro atua como signo que auxilia na sua organização.

Com base na natureza dos grupos que constrói e nos procedimentos utilizados para tal fim, é possível deduzir se o sujeito usa efetivamente o pensamento conceitual para tentar resolver o problema, dado que cada novo passo nesse raciocínio se reflete na manipulação das peças (Vigotski, 2007, p.184).

É interessante observar que, ao mesmo tempo em que o autor adota um experimento apartado da vida da criança (palavra sem sentido), critica, em sua obra Psicologia Pedagógica, o experimento de ensino que se utiliza de estratégias e situações artificiais sem sentido no processo educativo desenraizado da vida. Conforme diz: "Na própria natureza do processo educativo, em sua essência psicológica, está implícita a exigência de um contato e de uma interação com a vida que sejam o mais estreito possível" (VIGOTSKI, 2003, p.300). Aquele experimento 
traz em si um aspecto que merece reflexão: são utilizadas palavras artificiais que ele afirma serem sem sentido. Mas é possível uma palavra completamente sem sentido?

A palavra "bik" (бик), por exemplo, empregada por ele, pode induzir algum sentido ligado à palavra russa "bik" (бык) que significa "touro", alterando apenas o tipo de "i" e a pronúncia. E a palavra "tsev" ("цев") pode induzir à palavra "tsvetok" ("цветок") que quer dizer "flor", por ter as mesmas letras no início, mesmo que em ordem diferente "tsve" ("цве"). Ou seja, qualquer palavra escrita ou pronunciada, mesmo que não exista no léxico, pode trazer à mente algum sentido. Portanto, o espaço experimental criado por Vigotski não era tão experimental assim, pois a variável sentido não estava sob controle. Ao projetar instrumentos sob as configurações da mente na perspectiva da ciência moderna, submete-se a natureza às condições do experimento científico, criando-se uma ilusão (ARENDT, 2009a).

Por meio do experimento conduzido por Vigotski, é possível perceber como os princípios da ciência moderna estão na base da produção científica da época. Com o novo regime social estabelecido, como afirma Prestes (2010, p.28), "a Rússia socialista apresentou a tarefa de criar os fundamentos da psicologia e da pedagogia soviéticas, que tinham por objetivo a formação do homem novo, o que criava a demanda de novos modos de pensar a ciência". A urgência de formar um homem socialista e de erguer a União Soviética fazia despontar a necessidade de uma nova proposta de educação atrelada à ciência, de modo a atender às necessidades do contexto social e econômico da época. Havia uma estreita relação entre a produção científica e o processo de aceleração do socialismo soviético.

Nos anos 20 do século passado, em sua obra Psicologia Pedagógica, Vigotski (2003) deixa clara sua posição marxista ao enfocar a necessidade de uma pedagogia ativa de base científica, em que o professor teria uma atitude de pesquisador, de cientista, não de transmissor, simplesmente, de conteúdos. Nessa perspectiva, ele criticava radicalmente a escola, que se ocupava simplesmente da transmissão de conteúdos desvinculados da vida. Com a Revolução Russa de 1917, adveio a esperança de uma nova sociedade e, com ela, uma educação pelo trabalho que, por estar tão enraizada na vida concretamente vivida, levaria ao desaparecimento da instituição escolar. Por meio da educação pelo trabalho, a aprendizagem ocorreria em diferentes espaços sociais, ou seja, não haveria uma única instituição responsável pela instrução. 
Contudo, nos anos de 1930, algumas críticas às ideias de Vigotski consistiram no fato de que ele não apontou como sendo a origem da consciência ${ }^{6}$ individual a consciência de classe; assim como, também, criticou severamente a instituição escolar. Nessa mesma época, ele enfrentou dificuldades para publicar seus artigos e textos.

Entretanto, em sua obra Pensamiento y habla (2007), Vigotski ressalta a importância da instituição escolar como possibilitadora das condições necessárias de acesso ao conhecimento e à formação dos conceitos científicos, indicando o caminho para o desenvolvimento da sociedade soviética. De certa forma, ele se concilia com a instituição escolar e atende aos princípios do Partido Comunista, segundo Caruso (2007).

Foi com base na crença da precisão do experimento científico que Vigotski acreditou ter encontrado o procedimento adequado para examinar a formação de conceitos por meio do uso funcional da palavra. Ele estabeleceu dois grupos de conceitos: os cotidianos e os científicos, que se originam em atividades distintas e, por relacionarem-se diferentemente com a experiência de vida da pessoa, desenvolvem-se e funcionam de forma diversa. Os conceitos cotidianos teriam origem em atividades práticas, na relação direta da palavra com o objeto, enquanto que os científicos seriam desenvolvidos por meio da instrução formal, nas relações semióticas entre as palavras, propiciando a consciência do próprio pensar. Esses dois conceitos não estão isolados, mas imersos em um processo de contínua interação (VYGOTSKI, 1997a).

O desenvolvimento dos conceitos cotidianos e científicos seguiria vias diferentes, apesar da interferência mútua. A força dos conceitos científicos consistiria na utilização intencional e consciente das generalizações do significado das palavras e das relações estabelecidas entre elas. E é justamente esse aspecto que Vigotski afirma ser a debilidade dos conceitos cotidianos, os quais teriam como seu aspecto forte a utilização espontânea, situacional-significativa e concreta da palavra na esfera da experiência e do empirismo. A debilidade do conceito científico radicaria-se, por sua vez, em seu verbalismo e na insuficiente saturação do

\footnotetext{
${ }^{6}$ Vigotski (2004) elaborou um modo diferente de compreender a consciência, como unidade estrutural do comportamento humano. Diz ele: "A consciência é tratada como um problema da estrutura do comportamento. A consciência é a experiência das experiências [Perejivanie - vivência], assim como as experiências são simplesmente as experiências de objetos"(p.71-72).
} 
concreto. À medida que o verbalismo deixasse de preponderar, o conceito científico se aproximaria da concretude do conceito cotidiano. O desenvolvimento da consciência dos conceitos requereria a sua sistematização, baseada em determinadas relações de generalidade entre os conceitos e seu emprego voluntário (VIGOTSKI, 2007).

Um aspecto que merece ser realçado é o fato de que, ao criar essas duas categorias de conceitos, Vigotski não rompeu com a separação platônica entre o saber e o fazer. Nessa perspectiva, o conhecimento científico ocupa lugar de comando e de poder social, enquanto que o fazer e o executar ocupam o espaço de obediência, experiência e de materialização do pensado (ARENDT, 2009a). Vigotski adotou uma postura formalista em sua investigação, ao indicar a superioridade do científico sobre o cotidiano. Além disso, seu estudo apresentou um enfoque progressista, ao propor subclassificações que culminam num momento superior, o surgimento dos conceitos potenciais, que possibilitariam o desenvolvimento dos conceitos científicos.

O autor considerava que o desenvolvimento dos conceitos científicos criaria uma zona de possibilidades para o desenvolvimento dos conceitos cotidianos e vice-versa. Destacava, também, que aqueles possibilitariam a formação da consciência reflexiva, o que será discutido mais adiante, estariam apoiados nos conceitos elaborados durante a experiência da criança, de forma análoga ao estudo de uma língua estrangeira, que se ancora na semântica da língua materna. Essa afirmativa foi feita com base no exame comparativo realizado por ele sobre 0 processo de instrução de uma língua estrangeira e o de assimilação da língua materna. Seu estudo demonstrou que a assimilação de uma língua estrangeira possibilita elevar o conhecimento da língua materna, pois, no processo de interferência mútua, a debilidade de uma é influenciada pelo aspecto forte da outra. Ou seja, o aspecto forte da língua materna é a fluência verbal e sua espontaneidade, e o da estrangeira é o conhecimento da estrutura gramatical da fala escrita. Para Vigotski, ambos os processos influenciam-se, pois, ao mesmo tempo em que o ensino de uma língua estrangeira assenta-se no conhecimento da língua materna, propicia melhor entendimento da estrutura linguística desta. Isto é, com o domínio de um idioma estrangeiro, a utilização autônoma da palavra como instrumento do pensamento e como expressão do conceito possibilita a consciência das formas linguísticas da língua materna. Ambos os processos pertencem ao âmbito do 
desenvolvimento da fala oral e da fala escrita, que constitui uma nova variante dentro do mesmo processo de desenvolvimento linguístico. A aquisição de um idioma estrangeiro e, por conseguinte, o melhor domínio da língua materna, seria muito semelhante à dinâmica de influência mútua no desenvolvimento do conceito cotidiano e do científico.

Da mesma forma que a instrução de um idioma estrangeiro exige o domínio do aspecto semântico da língua, o desenvolvimento dos conceitos científicos requer o uso voluntário de conceitos em um sistema, bem como o domínio da linguagem com sua simbologia científica. Enquanto o idioma materno evolve pelo emprego livre e espontâneo da fala para, depois, haver o domínio da estrutura da língua e das formas verbais, o desenvolvimento de um idioma estrangeiro começa pelo domínio voluntário da gramática e de sua estrutura verbal, para depois acontecer a fluência da fala livre e espontânea. $O$ conceito cotidiano apresenta uma natureza espontânea, ligada diretamente ao significado da situação, ou seja, está no limite da experiência direta da pessoa em sua vida diária. Já o conceito científico com seu verbalismo exige o estabelecimento de relações semânticas entre palavras e seu domínio (VIGOTSKI, 2007).

Resta ainda examinar outra distinção feita por Vigotski entre os conceitos científicos e cotidianos: a relação com o concreto. Reiterando o que já se disse, para ele, o conceito cotidiano, diferentemente do cientifico, é saturado de concretude. É inegável a base marxista de sua teoria; daí porque seria esclarecedora da sua posição uma consulta, ainda que rápida, do que Marx considera como concreto.

Em seu exame sobre a economia política, Marx (2011) contrapõe o idealismo hegeliano, que concebe a consciência do mundo real como produto de uma determinação abstrata do pensamento, com o método científico, que se ancora na concretude do real, ou seja, entende que "as determinações abstratas conduzem à reprodução do concreto pela via do pensamento"(p. 248). Para Marx (1983, p.35) ${ }^{7}$,

o concreto é concreto por ser a síntese de diversas determinações, ou seja, ele é Unidade da Diversidade. No pensamento, ele aparece como um processo de síntese, como resultado e não como ponto de partida, embora

\footnotetext{
${ }^{7}$ Agradeço à Edna Carvalho de Azevedo por sua generosa tradução do texto do Marx.
} 
ele seja o verdadeiro ponto de partida e, por isso, também o ponto de partida da ideia e da representação.

Para ilustrar o que afirma Marx, toma-se, como exemplo, o conceito "pedra". O que é "pedra"? São necessárias inúmeras relações semânticas para definir esse conceito saturado de concretude. Logo, os conceitos cotidianos são profundamente complexos, pois compreendem até mesmo a síntese de relações conceituais. Será que o experimento com o emprego do método funcional da dupla estimulação abrange tamanha complexidade?

A descrição de como aconteceu o experimento faz-se necessária para o exame dessa questão. No início do experimento, as peças misturadas são dispostas sobre uma mesa. Elas apresentam variedade em tamanho, cor, forma e altura. Atrás de cada peça é escrita uma das quatro palavras (bik, tsev, lag, gur). Essas palavras não estão visíveis para a pessoa que participa do experimento. Independentemente da forma e da cor, todas as peças altas e grandes têm escrita a palavra lag; as planas e grandes têm em seu verso a palavra bik; as altas e pequenas, a palavra gur, e as planas e pequenas, tsev. O examinador pega uma das peças, mostra e lê a palavra para a pessoa e solicita a ela que selecione da mesa todas as que acredita pertencerem ao mesmo tipo de classificação que ele apontou. Quando a pessoa realiza a tarefa, o examinador escolhe uma das peças erroneamente selecionadas, lê a palavra e mostra que pertence a outra classe. Depois de cada tentativa de classificação, ele incentiva a pessoa a continuar com a atividade. A cada nova tentativa, o experimentador devolve as eleitas erroneamente e repete 0 procedimento. À medida que aumenta a quantidade de peças selecionadas, a pessoa estabelece critérios para descobrir as características das peças que se referem às palavras sem sentido. Quando faz essa descoberta, ela relaciona as palavras às classes de peças selecionadas, ou seja, separa as peças em acordo com as quatro classes indicadas pelas palavras sem sentido.

A observação de como os dois estímulos (propriedade física das peças e as quatro palavras) relacionam-se, um não verbal e outro verbal, possibilitou a Vigotski verificar a formação de um sistema funcional. Observar como aconteceu a manipulação das peças, a reação da pessoa frente às correções e a descoberta da solução apontam indícios de como a pessoa opera o pensamento, se ela tenta 
efetivamente utilizar 0 pensamento conceitual na resolução de problema (GONZÁLEZ, 2007; KOZULIN, 1994).

Kozulin (1994) destaca que a grande contribuição do experimento ao estudo de Vigotski foi explicitar que o momento crucial na formação dos conceitos é o uso da palavra como ferramenta funcional. Vigotski (2007) destaca que o experimento levou-o a concluir que a base psicológica do processo de formação dos conceitos tem suas raízes na tenra infância. $\mathrm{Na}$ adolescência, ocorre o amadurecimento dessa base psicológica. Isto é, antes da adolescência, as formações intelectuais são similares aos verdadeiros conceitos, mas somente na aparência, pois nesse momento de vida da criança há o desenvolvimento dos préconceitos, que se caracterizam em três tipos: sincréticos, por complexo e potenciais, como foi mencionado anteriormente.

A questão da concretude do conceito cotidiano não é explicitada na análise do experimento por Vigotski e nem o desenvolvimento das etapas de formação conceitual na infância elucida tal característica dada por ele ao conceito cotidiano. Na palestra As cadernetas e as anotações de L. S. Vigotski (1912-1934): as novas pesquisas do arquivo familiar, a Profa. Inna Koperanova ${ }^{8}$ relatou que, em sua pesquisa sobre a obra não publicada de Vigotski, encontrou em anotações pessoais dele do período de sua hospitalização, dias antes de seu falecimento, o registro de sua insatisfação a respeito do estudo que realizou sobre a formação de conceitos e do seu desejo de retomar seus escritos a respeito. Vigotski reconhecia que esse tema necessitava ser revisto.

Os estudos realizados por Vigotski demonstram que a análise do uso funcional da palavra no desenvolvimento do pensamento conceitual contribui para o entendimento de que é por meio dos desafios requeridos por uma tarefa, da necessidade do emprego de conceitos para sua resolução, bem como do acesso à vida cultural, profissional e social que as novas exigências suscitam o desenvolvimento do pensamento.

\footnotetext{
8 Palestra proferida na Semana de Psicologia: Psicologia Histórico-cultural, realizada no Centro Universitário de Brasília/UNICEUB, em 1ํ de setembro de 2010 (anotações pessoais).
} 


\section{O processo de desenvolvimento do pensamento por conceito}

Um ponto central no processo de formação de conceitos é o uso funcional do signo ${ }^{9}$, da palavra, como instrumento de domínio das operações psicológicas, conforme diz Vigotski (2007, p.179): "[...] a palavra é esse signo que serve de meio para a formação dos conceitos e logo se converte em seu símbolo". Ela é "a unidade de som e significado que, semelhante a uma célula, contém em si as propriedades fundamentais inerentes ao conjunto do pensamento discursivo em seu aspecto mais simples" (VIGOTSKI, 2007, p.15). O conceito é impossível sem a palavra.

Pelo emprego intencional da palavra, ferramenta cultural, a pessoa dirige sua ação na atividade, com vistas a resolver uma tarefa. Nesse processo, as funções psicológicas superiores são mediadas pelo signo. Elas não se desenvolvem isoladamente, mas estão interrelacionadas, transformam-se e apresentam uma nova combinação, uma nova síntese, adquirindo seu valor funcional. O signo atua como estímulo orientador das funções psíquicas em diferentes atividades da vida.

A passagem do pensamento à palavra é algo complexo, compreende a decomposição dele e sua recriação em palavras. O pensamento e a palavra não coincidem; logo, a comunicação imediata e direta entre consciências é possível pela encarnação do pensamento na palavra (VIGOTSKI, 2007).

Por ser guiada pela palavra, a atividade humana possibilita a transformação dialética das funções psíquicas elementares, de ordem biológica, em funções psíquicas superiores, de ordem cultural (VYGOTSKI, 1997a, 1997b, 1997c, 1997d; VIGOTSKI, 2007, 2009). As funções psíquicas superiores se desenvolvem com o uso do signo como elemento essencial para dirigi-las e dominá-las. Têm uma origem histórica e seu desenvolvimento é condicionado pelo contexto social e cultural da humanidade. Elas aparecem em dois momentos no processo de desenvolvimento da pessoa: inicialmente, no campo interpsicológico, como uma

\footnotetext{
9 Vigotski chamava de signos "aos estímulos-meios artificiais introduzidos pelo homem na situação psicológica, que cumprem a função de auto-estimulação, conferindo a este termo um sentido mais amplo e, ao mesmo tempo, mais exato do que se dá habitualmente a esta palavra. De acordo com nossa definição, todo estímulo condicional criado pelo homem artificialmente e do que se utiliza como meio para dominar a conduta - própria ou alheia - é um signo. Dois momentos, portanto, são essenciais para o conceito de signo: sua origem e função" (VYGOTSKI, 1997c, p.83).
} 
função do comportamento coletivo e colaborativo, como meio da adaptação social; e, posteriormente, no campo intrapsicológico, como um processo interior do comportamento, meio de adaptação $^{10}$ pessoal, individual. No processo de desenvolvimento psicológico, o mais importante é a mudança nas relações interfuncionais e não o desenvolvimento isolado de cada função psíquica. $O$ surgimento de novos arranjos interfuncionais acontece como um sistema psicológico em que os nexos entre as funções psíquicas se modificam de modo dinâmico e singular.

O desenvolvimento das funções psíquicas mantém relação direta com o da fala, que é de origem social e emocional. É no convívio social e no emprego das ferramentas culturais que existem as possibilidades para 0 desenvolvimento psíquico. Quando nasce, a criança está mergulhada na cultura e, desde muito pequena, estabelece contato com as pessoas à sua volta; inicialmente, por meio do choro e do balbucio; depois, com as primeiras palavras, principiando o desenvolvimento da função social da fala (VIGOTSKI, 2007).

A função da fala, primeiramente, é comunicativa e social; a criança estabelece contato com o outro para ter suas necessidades atendidas. Em seu primeiro ano de vida, o pensamento, que tem uma origem histórica e cultural, encontra-se em estado pré-verbal, enquanto que a fala está na fase ${ }^{11}$ pré-intelectual (VIGOTSKI, 2007).

Em seguida, principia o desenvolvimento da fala egocêntrica. Para Vigotski, esse tipo de fala é o ponto de transição da fala externalizada para a interna; isto é, da função interpsíquica à intrapsíquica da fala. Esta é sonora por sua manifestação e interna por sua função e estrutura. A criança começa a exercer, com apoio da fala egocêntrica, fala de transição, o controle interno de sua conduta. Essa fala auxilia a criança a organizar o seu pensamento e a sua ação. Ao expressar suas ideias, seu pensamento, de forma sonora, a criança planeja sua ação vinculada à sua experiência direta. A função da fala de transição é importante para a orientação mental, para a superação das dificuldades e dos obstáculos, para o pensamento (VIGOTSKI, 2007). No enfrentamento de uma situação difícil, a criança resolve seus

\footnotetext{
${ }^{10}$ Para Vigotski $(2007,1997 a)$, a adaptação refere-se à satisfação de necessidades enraizadas na realidade. A necessidade e a adaptação devem ser analisadas em sua unidade.

11 "Fase", para Vigotski, compreende o momento do processo de desenvolvimento em sua relação com o enraizamento social e cultural da pessoa.
} 
problemas com as palavras, delineia e planeja as ações em voz alta, ou seja, pensa com as palavras, ainda que seja de maneira muito incipiente (VYGOTSKI, 1997b, 1997c).

Finalmente, surge a fala interna que exige maior nível de abstração do que a externalizada e possui uma sintaxe particular. Ela é predicativa, constitui-se quase sem palavras, opera com a semântica e não com a fonética da fala oral e tampouco com a estrutura linguística da fala escrita: "[...] a fala interna é dinâmica, instável, variável e oscila entre os dois polos extremos [...] mais formados e estáveis, do pensamento verbal: entre a palavra e o pensamento"(VIGOTSKI, 2007, p.503-504). Entretanto, não deve ser considerada como uma fala sem som, mas uma fala com uma função particular e singular por sua estrutura e função. Vigotski ressalta que a fala interna apresenta um dialeto próprio. Conforme a situação vivida, são desenvolvidos matizes semânticos que convertem os significados das palavras em "significados individuais, compreensíveis apenas no plano da fala interna" (p.500, 501).

Em seu texto Sobre a análise pedológica do processo pedagógico, Vigotski (2010) afirma que a passagem da fala interna para a escrita é um processo complexo, pois, de uma dinâmica predicativa, com uma sintaxe muito singular, passa para uma fala que exige, para ser compreensível, uma estruturação de ideias, em conformidade com as normas gramaticais da língua. Enquanto a fala interna é uma fala para si, a escrita é uma fala para o outro, que está ausente. Na fala escrita, a criança precisa ter consciência do processo de expressão das ideias em palavras; ao mesmo tempo, precisa ter consciência das próprias palavras para uma estruturação textual.

Para Vigotski (2007), a fala tem um papel central no desenvolvimento do pensamento. No início da vida da criança, pensamento e fala encontram-se separados. Todavia, à medida que a criança cresce, o convívio social se amplia e ela percebe que cada coisa à sua volta tem um nome. Seu vocabulário aumenta e ela sente a necessidade da palavra para denominar os objetos. Nesse momento, as duas funções que se encontravam separadas unem-se, formando uma unidade dialética, de modo que o pensamento torna-se verbal e a fala intelectual. Ou seja, tem início o processo de desenvolvimento que Vigotski denomina pensamento verbal. O pensamento verbal não é uma forma natural e espontânea de 
comportamento, mas uma forma sócio-emocional-histórico-cultural, isto é, unidade entre pensamento e fala; generalização e comunicação (VIGOTSKI, 2007).

Assim, o pensamento realiza-se na palavra, que é unidade da fala. "[...] a fala (a palavra) nem produz, nem expressa o pensamento: ela o mediatiza; nós pensamos com a palavra" (TUNES, 2000, p.38). Para Vigotski (2007), o significado da palavra, que é uma generalização e se desenvolve, é a unidade de análise do pensamento verbal. O significado da palavra não é nem fala, nem pensamento. É pensamento e fala.

Uma palavra privada de significado não é uma palavra, senão um som vazio. [...] do ponto de vista psicológico, o significado da palavra não é outra coisa que uma generalização ou um conceito (VIGOTSKI, 2007, p.426).

O desenvolvimento do conceito acontece em um sistema que compreende um conjunto de traços gerais do objeto e de conexões estabelecidas entre outros conceitos (VYGOTSKI, 1997d). O significado da palavra é um fenômeno verbal e intelectual e, apesar de apresentar um aspecto relativamente estável, não é constante, altera-se durante todo o processo de desenvolvimento. Está sujeito à influência do sentido da palavra, que é dinâmico e instável, que o transforma nas experiências da vida (VIGOTSKI, 2007).

Vigotski (2007) aponta que, em diferentes atividades e vivências ${ }^{12}$, as palavras podem mudar seu sentido e significado e adquirir um sentido específico, próprio das condições do momento. Há certa ascendência do sentido sobre o significado; logo, uma variedade de modos de relação entre pensamento e fala, uma enorme possibilidade de relações conceituais que se estabelecem em diferentes atividades.

\footnotetext{
12 Conforme define Vygotsky (1998, p.294), "vivência da criança é o tipo de unidade muito simples sobre a qual é impossível dizer que represente a influência do ambiente sobre a criança ou a individualidade da própria criança; a vivência é uma unidade da personalidade e ambiente tal como representada no desenvolvimento. A vivência deve ser compreendida como a relação externa da criança como pessoa com um ou outro fator da realidade. Mas toda vivência é minha vivência. Na teoria moderna, a vivência é introduzida como uma unidade da consciência, isto é, uma unidade em que as propriedades básicas da consciência são dadas como tais [...] a vivência é a dinâmica real da unidade da consciência, isto é, o todo que contém a consciência".
} 
[...] o sentido da palavra é inesgotável. A palavra adquire seu sentido só na frase, mas a própria frase adquire sentido só no contexto do parágrafo, o parágrafo no contexto do livro, o livro no contexto de toda a obra do autor. $\mathrm{O}$ verdadeiro sentido de cada palavra se define, em última instância, por toda a abundância de aspectos existentes na consciência relativos ao expressado pela palavra. (p.494 e 495)[...] o predomínio do sentido sobre o significado, da frase sobre a palavra, de todo o contexto sobre a frase não constitui uma exceção senão uma regra permanente (VIGOTSKI, 2007, p.496).

Em seus estudos, Luria (1979) reafirma a influência do sentido, que se altera conforme a situação vivida, mudando, assim, o significado da palavra. Dessa forma, um sistema de relações de significados surge como alternativa para o emprego da palavra: "O sentido da palavra, que depende da tarefa concreta [...] e da situação concreta em que se emprega a palavra, pode ser totalmente diferente embora exteriormente permaneça o mesmo" (p.22). Acrescenta, ainda, o fator da entonação da palavra pronunciada que, paralelamente à situação do momento, tem a propriedade de alterar o seu sentido. Um exemplo apresentado por ele consiste na pronúncia da palavra besta que, verbalizada sem entonação especial, significa uma espécie de animal, mas quando pronunciada com tom de voz alto, áspero e irritado, adquire o sentido de pessoa tola, simplória e pedante.

\footnotetext{
O processo de emprego real da palavra é a escolha do sentido adequado entre todos os possíveis significados da palavra e somente existindo um sistema de escolha que funcione com precisão, com o realce do sentido adequado e a inibição de todas as outras alternativas, o processo de uso das palavras pode desenvolver-se com êxito para a expressão do sentido e a comunicação (LURIA, 1979, p.23).
}

Por sua vez, a atividade do pensamento é dinâmica e diversa, envolvendo a interrelação das palavras, formadas e desenvolvidas nas atividades da vida, por meio de conexões conceituais em sua relação com a realidade (VYGOTSKI, 1997a).

Em seus estudos a respeito do desenvolvimento da consciência, Vigotski (2004) afirma que esta compreende a capacidade humana de perceber os próprios reflexos como novos excitantes ou estímulos. Portanto, a consciência é por ele entendida como propriedade estrutural do comportamento. A palavra escutada funciona como um excitante, reflexo reversível, pois "o excitante pode se transformar 
em reação e vice-versa. Esses reflexos reversíveis, que criam a base do comportamento social, servem de coordenação coletiva do comportamento" (p.81). Ou seja, por meio da fala, "a palavra pronunciada é um reflexo que, por sua vez, cria um estímulo; a palavra-estímulo a mim dirigida por outros, posso pronunciá-la, também, como estímulo, a mim mesmo" (TUNES; BARTHOLO, 2004, p. 48). Vejase um exemplo: a pessoa movimenta o braço, estendendo-o para trás e, mesmo que esteja fora do seu campo de visão, ela sabe que ele está estendido. Essa mesma pessoa pode estender o braço ao ouvir um comando. E pode ocorrer também de pronunciar para si o comando. Nesse instante, a palavra pronunciada pode tornar-se um novo excitante para ela e também para o outro.

A consciência se desenvolve em um sistema semântico, havendo mudanças nas relações entre as diversas funções. Com o desenvolvimento do pensamento por conceito científico, com sua estrutura e natureza semiótica, a consciência passa por modificações estruturais e funcionais. Modificam-se as relações lógicas entre as palavras, seus significados se desenvolvem, os nexos interfuncionais se modificam. Isso acontece porque a pessoa está ciente do seu próprio ato de pensar, da relação que ela estabelece entre diversos conceitos (VIGOTSKI, 2004). Desenvolve-se, assim, a consciência reflexiva, que consiste na "capacidade de utilizar, voluntariamente, as palavras como 'instrumento' do pensamento e como meio de expressão de ideias" (TUNES, 2000). Desenvolver a consciência reflexiva, o pensar voluntário, possibilita passar do plano do pensamento para o plano da fala e vice-versa. Como diz Vygotski (1997b, p.269): "Tomar consciência significa em certa medida dominar".

A consciência representa uma orientação da atividade psíquica enraizada na realidade e está baseada na generalização dos processos psíquicos e no seu domínio. Como diz Vigotski (2007, p.311), “[...] a mudança da estrutura funcional da consciência constitui o elemento central e fundamental de todo o processo de desenvolvimento psíquico".

Para Vygotski (1997b), toda atividade intelectual, seja ela de ordem teórica ou prática, tem sua própria dinâmica. Ele afirma não haver dois tipos de dinâmicas independentes do caráter das funções que são postas em movimento, nem dois tipos de atividade independentes dos sistemas dinâmicos que estão em sua base, mas sim duas unidades de funções dinâmicas: o pensamento teórico e o pensamento prático, cada um com sua dinâmica particular. Ambos não 
caracterizam dois campos desvinculados um do outro, porquanto é notória, no cotidiano, a transformação do pensamento em ação e da ação em pensamento. Entre o sistema dinâmico de atividade do pensamento prático e o do pensamento teórico há uma relação dialética, que constitui uma propriedade estrutural do comportamento humano. No trânsito do sistema de atividade do pensamento prático para o teórico e vice-versa, existem três momentos fundamentais na transformação da dinâmica do campo psicológico: a transformação do pensamento prático em pensamento teórico, o desdobramento dos processos dinâmicos do pensamento teórico e a transformação deste em ação. Tais momentos estão na base da ação que se transforma em outra ação plena de sentido, voluntária e apenas indiretamente atrelada à situação real.

Para Vigotski, toda atividade é movida por uma necessidade ${ }^{13}$. Conforme já foi dito, as funções psíquicas superiores aparecem em dois momentos, no processo de desenvolvimento: seja como meio de adaptação social, seja como meio de adaptação pessoal, individual. Ora, se a adaptação e a satisfação da necessidade compõem, segundo ele, uma unidade, é forçoso concluir que toda atividade humana contém estruturalmente a possibilidade de promover o trânsito do pensamento à ação e vice-versa. Em síntese, toda atividade pode possibilitar o desenvolvimento da consciência reflexiva. Isso dependerá da natureza da unidade adaptação-necessidade com que a pessoa se engaja na atividade, mais do que do fato de esta ser ou não cotidiana.

\section{Conceito cotidiano versus científico?}

O ingresso da criança na escola constitui um marco social em sua vida, momento em que se inicia o processo formal de instrução dos conhecimentos reconhecidos por uma sociedade escolarizada cientificista. Mas não há como negar que o processo de instrução está presente na vida da criança desde a tenra idade.

\footnotetext{
13 Se o leitor desejar esclarecimentos sobre a relação entre atividade e necessidade, sugere-se a seguinte leitura: VIGOTSKI,L.S. A Brincadeira e o seu papel no desenvolvimento psíquico da criança. Tradução Zoia Prestes. Revista Virtual de Gestão de Iniciativas Sociais. Universidade Federal do Rio de Janeiro. Rio de Janeiro, №11, 2008.
} 
Antes de ingressar na escola, ela já teve acesso a informações, conhecimentos e valores, em suas relações sociais. Hoje, devido aos meios de comunicação, esse acesso pode até mesmo acontecer segundo o modo formal escolar, mas, ainda assim, pode-se dizer, sem medo de errar, que grande parte dele é realizada, informalmente, nas atividades cotidianas (TUNES; CARNEIRO, 2002).

Vigotski (2010) analisa a relação entre os processos de instrução e de desenvolvimento, presentes no espaço escolar. Ele afirma que a boa instrução é aquela que antecede o desenvolvimento. Não se trata de instrução como técnica e treino de funções já desenvolvidas, mas de possibilitar as condições para o desenvolvimento de funções psíquicas. A instrução é uma atividade cujo sentido não se encontraria no resultado, mas nela mesma. Nesta atividade, certamente, há condições estruturais que possibilitam a passagem da adaptação social para a individual.

$\mathrm{Na}$ atividade de instrução, estão presentes intencionalidades daquele que deseja ensinar e do outro que quer aprender. Ou seja, há uma disposição autônoma de vulnerabilidade de ambas as partes. Não se pode deixar de mencionar que um livro pode fazer o papel desse outro, pois o que move a pessoa é a necessidade de instruir-se.

\begin{abstract}
Parece que os processos de instrução despertam na criança uma série de processos de desenvolvimento interno, despertam no sentido de que os incitam à vida, os põem em movimento, dão partida a esses processos. No entanto, entre a marcha desses processos de desenvolvimento interno despertados pela instrução e a marcha dos processos da instrução escolar, isto é, entre a dinâmica de ambos, não existe paralelismo (VIGOTSKI, 2010, p.280-281).
\end{abstract}

O desenvolvimento apresenta uma lógica e um ritmo próprios não atrelados ao programa escolar. A marcha desses dois processos, a instrução e o desenvolvimento, é dinâmica e não se dá paralelamente. Trata-se de dois processos que têm relações internas complexas (VYGOTSKI, 1997a). Preocupado com a instrução escolar, Vigotski (2010) destacou que a instrução, para ser autêntica, deve incitar o desenvolvimento, criando as possibilidades de neoformações psíquicas. 
Se a instrução utiliza apenas as funções já desenvolvidas, então, temos diante de nós um processo semelhante de instrução do escrever à máquina. Vamos esclarecer bem a diferença entre ensinar a escrever à máquina e ensinar a escrita à criança. A diferença é que, se começo a escrever à máquina, não ascendo a um estágio superior da fala escrita, apesar de poder receber uma qualificação profissional. A criança, por sua vez, adquire um saber e toda a estrutura de suas relações e da fala altera-se: de inconsciente torna-se consciente, de um mero saber transforma-se em saber para si. Somente é boa a instrução que ultrapassa o desenvolvimento da criança. [...] Existem fundamentos para supor que o papel da instrução no desenvolvimento da criança consiste em criar a zona de desenvolvimento iminente. ${ }^{14}$ (VIGOTSKI, 2010, p.283).

O autor critica severamente a escola que segue os moldes escolásticos, nos quais o conhecimento das ciências está desvinculado das questões pertinentes à vida e fragmentado em disciplinas. Além do mais, nessa perspectiva, o conhecimento científico é tomado como verdade, valorizado por ser fruto de uma atividade de pura abstração mental. Como forma de vencer a fragmentação e o isolamento dos conhecimentos, Vigotski, na época, defendia a ideia da educação pelo trabalho, sob a alegação de que esta possibilitaria a síntese e a unificação dos conhecimentos relacionados com a atividade prática e social, propiciando, assim, a busca da descoberta da verdade e o retorno da educação à atividade do trabalho. Cabe esclarecer que, para a visão marxista, é por meio do trabalho que o homem constitui-se humano, em um processo dialético entre ele e a natureza, pois, ao mesmo tempo em que o homem, por sua própria ação, controla e intervém na natureza para atender a suas necessidades imperativas, é modificado por ela. Conforme diz:

Nessa escola puramente voltada ao trabalho, o trabalho não se incorpora como tema de ensino nem como método ou meio de ensino, mas como matéria-prima da educação (p.189).[...] a experiência pedagógica revelou que a disciplina formal das matérias costuma ser sumamente insignificante.[...] os processos gerais de memorização não manifestam de forma alguma nenhuma melhora [...] portanto, a disciplina formal de cada

\footnotetext{
14 No texto Sobre a análise pedológica do processo pedagógico, Vigotski define o conceito zona de desenvolvimento iminente: "Pesquisas permitiram aos pedólogos pensar que, no mínimo, deve-se verificar o duplo nível do desenvolvimento infantil, ou seja: primeiramente, o nível de desenvolvimento atual da criança, isto é, o que, hoje, já está amadurecido e, em segundo lugar, a zona de seu desenvolvimento iminente, ou seja, os processos que, no curso do desenvolvimento das mesmas funções, ainda não estão amadurecidos, mas já se encontram a caminho, já começam a brotar; amanhã, trarão frutos; amanhã, passarão para o nível de desenvolvimento atual. Pesquisas mostram que o nível de desenvolvimento da criança define-se, pelo menos, por essas duas grandezas e que o indicador da zona de desenvolvimento iminente é a diferença entre esta zona e o nível de desenvolvimento atual" (VIGOTSKI, 2010, p.267).
} 
matéria está ligada apenas a melhoramentos imperceptíveis no terreno da acumulação de hábitos. (p.191-192) [...] o pecado psicológico de todo o sistema escolástico e clássico de educação foi o caráter absolutamente abstrato e inerte dos conhecimentos. [...] Nenhuma noção psicológica sobre a verdade é mais falsa que aquela que nossos alunos extraíam dos manuais escolares. [...] a verdade sempre era apresentada sob a forma de uma regra teórica abstrata, que não era obtida através de um processo de busca e trabalho, mas através de um labor puramente mental (VIGOTSKI, 2003, p.194).

Nessa perspectiva, a instrução não está restrita ao espaço escolar. Tratase de um processo amplo que promove o desenvolvimento psíquico. Por meio da palavra, fonte do comportamento social, o processo psíquico se modifica e se reorganiza. A atividade humana é um processo mediado por essa ferramenta cultural, na produção e apropriação da cultura, condicionante do desenvolvimento humano.

Ao diferenciar os conceitos em sua estrutura, gênese e função, Vigotski (2007) afirma que os cotidianos são constituídos na experiência diária e estão estruturados de forma assistemática, possibilitando o enraizamento da pessoa na vida do dia a dia, enquanto que os científicos estruturam-se em sistemas hierárquicos de coordenação e subordinação lógicas, desenvolvidos pela instrução formal escolar, possibilitando o desenvolvimento da consciência reflexiva, o pensar sobre o próprio pensar.

Ao fazer essa distinção, ele dicotomiza a atividade do pensar e a do fazer e desconsidera que a escola faz parte da cotidianidade. Ele releva a diversidade e complexidade do cotidiano com suas possibilidades desenvolvimentais, mas supervaloriza o conhecimento científico, admitindo, de certo modo, que a atividade científica estaria fora da vida cotidiana.

Ainda, a presunção de que a diferença estrutural entre esses tipos de conceitos encontra-se na presença ou ausência de sistematização parece não se sustentar, conforme se ilustra a seguir:

Imagine, por exemplo, que uma criança de, aproximadamente, três anos de idade esteja se arrumando, com a ajuda da mãe, para ir ao aniversário de um amigo. A uma certa altura, a mãe pergunta-Ihe: - Que roupa você quer vestir? Repare que a palavra roupa não se refere a uma em particular, mas a todas aquelas que se encontram no armário do quarto da criança. Assim, 
essa palavra já é uma categoria com algum grau de abstração (TUNES; CARNEIRO, 2002, p.38).

Quando a mãe pergunta à criança que roupa esta irá vestir, estabelece uma relação entre conceitos: sapato, meia, calça, blusa. Eles estão no mesmo plano de generalidade, ou seja, são coordenados. Mas relacionam-se com o conceito "roupa", que está em outro plano de generalidade, de forma supraordenada. Frente ao seu armário, certamente, a criança pensou nos objetos e, operando com conceitos forjados no cotidiano, estruturou-os em um sistema conceitual, mesmo que incipiente, para responder à sua mãe. Esse é um dos tantos exemplos de relações sistêmicas que estão presentes no dia a dia da vida das pessoas, em atividades do dia a dia. Portanto, afirmar que não ocorre sistematização na cotidianidade parece não proceder.

No momento em que Vigotski concebe a origem dos dois conceitos como sendo a instrução formal escolar ou a atividade cotidiana, há que se presumir que o conhecimento científico e o escolar não fazem parte da vida cotidiana. Essa presunção é procedente? Para a análise dessa ideia é preciso examinar o que vem a ser a vida cotidiana, o que será realizado no próximo capítulo. 


\section{A VIDA COTIDIANA}

A caracterização do que vem a ser a vida cotidiana é feita de maneira distinta e, às vezes, antagônica por diversos autores. Entre os de inspiração marxista destaca-se Agnes Heller, filósofa e integrante da Escola de Budapeste ${ }^{15}$, aluna e, posteriormente, colaboradora intelectual de Georg Lukács ${ }^{16}$. Ao tratar teoricamente do que vem a ser o cotidiano, ela aponta como suas características a mecanização e a automação, o pragmatismo, o preconceito e a alienação. Cada uma dessas características será tratada a seguir.

O modo de vida cotidiano, para Heller (2004 e 1994), caracteriza-se por sua mecanização e automação (regularidade, ritmo fixo e rígido) e, por isso, o pensamento, no cotidiano, enraíza-se na experiência empírica e ultrageneralizadora. As ideias fragmentadas, os juízos de orientação social, próprios do pensar cotidiano, referem-se ao ambiente imediato. Sendo assim, as objetivações ${ }^{17}$ dizem respeito à particularidade; portanto, não são teóricas e nem a atividade cotidiana é práxis. Dessa forma, as ações do homem cotidiano baseiam-se em estereótipos e em analogias elaboradas mediante a possibilidade de consequências avaliadas previamente em sua vida diária pelo grupo social. Em outras palavras, o homem cotidiano faz avaliações probabilísticas em que o conhecimento proveniente de uma nova situação não tem importância, posto que apenas é considerado correto o que tem reconhecimento social porque se repete como possibilidade de ação.

Ao mesmo tempo em que Heller (2004) ressalta as características do cotidiano - a regularidade de ações do dia a dia, o ritmo padronizado de organização da vida diária e a atividade mecânica repetitiva -, argumenta que há atividades que não são realizadas todos os dias, mas pertencem à cotidianidade por exemplo, arrumar as malas para uma viagem a passeio à Europa -, assim como,

\footnotetext{
${ }^{15}$ Foi o nome dado ao grupo de pesquisadores filósofos de base marxistas cujos principais membros foram Luckács, Mészáros e Bhaskar.

${ }^{16}$ Filósofo húngaro e dedicado marxista de grande importância no cenário intelectual do século XX.

${ }^{17}$ São formas de objetivações: o trabalho, o comportamento, a atividade. Eles objetivam-se sempre, ou seja, transformam-se em ação, em atos. As objetivações podem ser particulares (exteriorizadas, voltadas para a adaptação e reprodução do particular) ou genéricas (direcionadas para os fenômenos sociais, ações que constituem estruturas de integração social) (HELLER, 1994).
} 
também, há atividades que são realizadas diariamente, mas que não pertencem à vida cotidiana - tais como a atividade científica e artística.

Todavia, ao afirmar que a vida cotidiana caracteriza-se pela repetição e rigorosa regularidade, Heller (2004) desconsidera a imprevisibilidade e a incerteza que estão presentes no cotidiano das pessoas, como aponta contrariamente Bakhtin (2008), em seu estudo sobre a cultura cômica popular na ldade Média e no Renascimento. Para o autor, o cotidiano compreende o mundo dos ideais, do espírito e das ideias, dos fins superiores da existência humana, do tempo presente, da ressurreição e da renovação, condições indispensáveis à plenitude da vida.

O cotidiano, na Idade Média, era vivificado em festejos do povo, em carnavais, festas dos tolos, do templo e festas agrícolas. Os festejos eram livres de qualquer dogmatismo e aconteciam nas praças públicas, onde as pessoas interpretavam de forma cômica os ritos que faziam parte da cotidianidade como ponto central das festividades. As representações nas praças públicas, apesar de não pertencerem ao domínio da arte, continham elementos artísticos, consistiam em uma forma concreta de interpretação da vida plenamente vivida, não havendo, para isso, uma fronteira espacial entre atores e espectadores, nem entre o palco e a vida. O desfecho era imprevisível, pois a cada apresentação, as pessoas participavam de modo diferenciado. Logo, as representações não se repetiam, uma vez que o desenrolar da trama era sempre diferente.

Com o propósito de contextualizar o ponto de vista de Bakhtin a respeito do cotidiano, é pertinente abordar outros aspectos que constituíam a cotidianidade na Idade Média. Havia dois mundos: um oficial, sob os olhares e o controle da lgreja e do Estado feudal; e um não oficial, o do povo. Nas praças públicas, espaço de convivência e de plena liberdade, o riso estava sempre presente com seu caráter libertador e universal, propiciando o renascimento e a renovação da cotidianidade. $O$ riso da Idade Média tinha um caráter bem diferente do riso dos dias atuais, como esclarece Bakhtin (2008, p.80):

O riso da Idade Média, que venceu o medo do mistério, do mundo e do poder, temerariamente desvendou a verdade sobre o mundo e o poder. Ele opôs-se à mentira, à adulação e à hipocrisia. A verdade do riso degradou 0 poder, fez-se acompanhar de injúrias e blasfêmias, e o bufão foi o seu porta-voz. 
Nada escapava à visão carnavalesca do mundo, a qual possibilitava o riso festivo de caráter ambivalente, que atingia a todas as pessoas. Os elementos que $o$ caracterizavam - universalidade, liberdade, igualdade e abundância - propiciavam uma vivência livre do regime vigente, das relações hierárquicas, dos privilégios, das regras e da verdade dominante. Enquanto durassem os festejos, era possível a convivência livre e familiar entre as pessoas, não mais separadas por diferentes condições sociais. $O$ contato familiar era irrestrito e a comunicação entre as pessoas era autêntica e sem barreiras.

O Estado feudal, em conformidade com a Igreja, reconhecia a autenticidade das festividades do povo com seu caráter humano. Como era de interesse de ambos, medidas de tolerância eram adotadas para realização das festas populares, como estratégia de manutenção das normas estabelecidas e de manter o povo sob controle. As medidas adotadas pelo Estado promoviam a manipulação das formas de expressão da vida autêntica e a alienação do cotidiano por meio de padrões estipulados. A verdade, expressada de forma libertária por meio de brincadeiras, paródias, grosserias e obscenidades, promovia a fé no riso festivo e desconfiança na seriedade. O riso não forjava dogmas e nem representava medo, apenas indicava renascimento, fecundidade, o futuro e o novo.

Outras formas de expressão da cotidianidade na cultura popular eram a literatura e a dramaturgia cômica medieval, com sua linguagem própria, as quais estavam imbuídas da concepção carnavalesca do mundo, em que o riso era o elemento fundante. A forma festiva de conceber o mundo era expressa também nas imagens cômicas que retratavam a vida cotidiana. Nelas, eram ressaltados o corpo e suas necessidades naturais em articulação com o mundo espiritual e divino. A ambivalência e a incompletude da vida eram expressas em sua totalidade; o corporal, o social e o espiritual eram retratados de modo entrelaçado. Isso pode ser verificado no realismo grotesco na obra de François Rabelais, Gargântua e Pantagruel. Com base em Rabelais, Bakhtin (2008, p.18-19) assim caracteriza o grotesco:

No realismo grotesco, a degradação do sublime não tem um caráter formal ou relativo. [...] Degradar significa entrar em comunhão com a vida da parte inferior do corpo, a do ventre e dos órgãos genitais, e, portanto, com atos 
como o coito, a concepção, a gravidez, o parto, a absorção de alimentos e a satisfação das necessidades naturais. A degradação cava o túmulo corporal para dar lugar a um novo nascimento. [...] é ambivalente, ao mesmo tempo negação e afirmação.

No final da Idade Média, inicia-se o enfraquecimento das fronteiras entre a cultura cômica e a literatura reconhecida de valor. Durante o Renascimento, o riso permanece como forma de expressão da verdade em sua totalidade sobre a história e o homem. A partir do século XVII e nos seguintes, o tom sério é o adequado, cabendo ao riso o lugar do gênero literário menor, de divertimento ligeiro. "Progressivamente, o universalismo cômico de tipo carnavalesco torna-se incompreensível" (BAKHTIN, 2008, p.98). O processo de reorganização do modelo de mundo tem início nesse período. A generalização, a abstração empírica e a tipificação são valores preponderantes na descrição do mundo. O racionalismo e a concepção mecanicista da matéria dão as bases para a compreensão da realidade. O caráter universal das festividades perde gradativamente sua preponderância com a prevalência das festas restritas ao mundo privado e a estatização das festas populares. O processo de decomposição do riso universal e libertário foi reduzido ao humor, ironia e sarcasmo, dando início à literatura recreativa, cômica e satírica.

Entretanto, o grotesco ressurge no Romantismo, nas obras artísticas e literárias da época que, diferentemente da Idade Média e do Renascimento, relacionam-se com a cultura popular na linguagem do pensamento filosófico idealista. As imagens da vida material e corporal, que retratavam a satisfação das necessidades naturais, nascimento e morte, perdem sua significação regeneradora para serem vistas como algo inferior, sob o princípio do temor, visão sombria do mundo.

Com base no estudo de Bakhtin, pode-se verificar que, com o advento do iluminismo, por meio do racionalismo científico, a concepção do cotidiano é transformada; a vida cotidiana é organizada e programada com vistas a atender a outras necessidades criadas pelas novas condições econômicas e sociais. Ao afirmar que o cotidiano é espaço de enfrentamento de tensões, conflitos, e que apresenta um tempo, um ritmo próprio demarcado pelo modo de produção e organização social, Kosik (2002) salienta que a regularidade da cotidianidade é dada pelas relações de produção. Bosi (2003, p.53) compartilha dessa ideia e diz: "[...] 
nossos ritmos temporais foram subjugados pela sociedade industrial, que dobrou 0 tempo a seu ritmo, 'racionalizando' as horas de vida. É o tempo da mercadoria na consciência humana".

A questão a ser destacada é que há diferentes cotidianidades, vividas em diferentes momentos históricos em conformidade com a sociedade, a cultura e as condições materiais. Além disso, há diferentes modos de viver a cotidianidade. $\mathrm{Na}$ escola, na fábrica, na repartição pública, no comércio, no campo, no presídio, no hospital, nos quartéis e no campo de concentração, o dia a dia caracteriza-se de forma singular, tanto de modo coletivo como individual.

Bosi (2003) analisa a cotidianidade de um campo de concentração nazista, durante a Segunda Guerra Mundial: o Campo de Theresienstadt, também chamado de Campo de Terezin por aqueles que lá viveram.

Theresienstadt, antiga cidade fundada em 1780, foi transformada em um campo de concentração, travestida como local de moradia de judeus renomados: artistas de fama internacional, cientistas, heróis de guerra e velhos. Contudo, era um local de trânsito, de onde partiam comboios para outros campos de concentração. Além da lista de deportação de prisioneiros para o leste, havia tentativas de fuga e mortes decorrentes da fome. O Campo de Terezin era administrado por líderes judeus sob a supervisão de oficiais nazistas. Ele serviu de propaganda nazista, foi inspecionado várias vezes pela Cruz Vermelha e nada que pudesse apontar maus tratos aos prisioneiros foi detectado (BOSI, 2003). Em um campo de concentração, por mais que o dia a dia seja rotineiro e repetitivo, a vida cotidiana não é só repetição e rotina mecanizada. A incerteza do amanhã está presente na vida das pessoas. A experiência do Campo de Terezin é um exemplo de como o cotidiano não é automatizado e repetitivo.

Os artistas organizavam apresentações, representações teatrais e concertos musicais, vivendo intensamente aqueles momentos. Como comenta Bosi (2003, p. 102): "Tocavam, dançavam e cantavam para um público que continuamente ia desaparecendo, sendo que eles próprios não podiam prever se estariam ali na próxima representação". Não havia garantias, ninguém poderia prever se amanhã estariam todos juntos. A pergunta para a qual não se tinha resposta, como cita Bosi (2003, p.89), era: "Quem irá desta vez?"

As atividades e o modo de viver na cotidianidade constituem um mecanismo de ação e de vida em que as ações, os objetos circundantes e o mundo 
não são examinados em sua originalidade, sendo simplesmente aceitos. A mecanização pode estar presente no cotidiano e a margem que separa o que é ou não passível de automação constitui um processo histórico. Na cotidianidade, o homem estabelece relações entre as atividades desenvolvidas por ele e a sua experiência com os acontecimentos da vida diária, tomando essa realidade como seu próprio mundo. A vida cotidiana é um mundo de intimidade, da familiaridade e, também, das ações banais (KOSIK, 2002).

Outra característica do cotidiano, salientada por Heller (2004), é o seu pragmatismo absoluto, sua heterogeneidade. A unidade imediata entre pensamento e ação implicaria a inexistência de diferença entre o correto e o verdadeiro - no sentido de que o correto é também verdadeiro -, e levaria também às ultrageneralizações. O saber cotidiano seria uma categoria objetiva, ao mesmo tempo normativa, teria sua origem na experiência, sendo transmitido de geração em geração e não constituiria uma esfera autônoma, pois possuiria propriedade heterogênea. Ou seja, ele seria sempre e somente opinião - doxa -, como comenta Heller (1994, p.343):

[...] uma verdade cotidiana é sempre doxa, ainda que se mostre constantemente verdadeira, enquanto que a verdade científica é episteme, mesmo que na manhã seguinte seja substituída por uma verdade de nível mais elevado.

O saber cotidiano acolheria certas aquisições científicas, mas não o saber científico como tal, pois, no cotidiano, não seria preciso conhecer a gênese de todas as aquisições, como afirma Heller (1994). O pensamento cotidiano seria destinado a resolver problemas do dia a dia. Por seu caráter pragmático, os processos de pensamento desenvolveriam-se em função de determinados objetivos práticos, dirigidos aos problemas do particular ou do ambiente. O conhecimento cotidiano assimilaria e englobaria em sua própria estrutura o conhecimento científico impregnado de pragmatismo, servindo, assim, de guia para a ação cotidiana, que passa a ser intelectualizada.

Ao mesmo tempo, Heller $(1994,2004)$ afirma que o emprego dos conhecimentos científicos na vida cotidiana não alteraria a estrutura do saber 
cotidiano. Esse modo de pensar da autora caracteriza um paradoxo, uma vez que a ação cotidiana é intelectualizada, como ela mesma apregoa. Sendo assim, o pensamento cotidiano receberia influência do pensamento científico, modificando o seu caráter provisório. Essa visão dicotômica do fazer cotidiano e do científico está baseada em critérios de provisoriedade e generalização.

Arendt (2009a) afirma que a "separação platônica entre o saber e o fazer" (p.237) perdura na modernidade, tanto na filosofia como na ciência. Ela salienta que a moderna divisão do trabalho em produtivo e improdutivo, em qualificado e não qualificado e, posteriormente, em intelectual e manual está calcada na visão dicotômica entre o saber e o fazer, como dois desempenhos que não estão em estreita relação. Entre o pensamento e a ação é estabelecida uma linha divisória, relacionando o conhecimento com o governo e comando e o fazer com a execução obediente. A autora (2009b) destaca que, com o advento da era moderna, o homem deixou de considerar a sua experiência cotidiana como uma verdade confiável. Apenas é veraz o que ele é capaz de conhecer e compreender. Ou seja, para ele, conhecer algo é compreender como esse algo veio a existir.

O modo helleriano de ver o cotidiano constitui uma questão problemática. A percepção que se tem da cotidianidade foi alterada após a generalização de dois fatores ocorridos no século XIX, como aponta Lefebvre (1991): o estabelecimento do capitalismo com sua economia mercantil e monetária e os estudos realizados pelas ciências que procuraram aproximar a realidade empírica e prática dos fatos da vida e da consciência. O primeiro fator suscitou o crescimento da prosa no mundo, a qual invadiu os textos e as obras, dissociando-os e classificando-os por um sistema de significação, afastando a poesia da especificidade da vida cotidiana. E o segundo fator promoveu a dicotomização entre razão e realidade, conhecimento filosófico e não-filosófico, conhecimento teórico e prático, espiritual e material. A administração e a organização do modo de vida, orientados pela economia e pela razão científica, fragmentaram o cotidiano, concedendo um atestado de cientificidade à ideologia disfarçada de racionalidade e de ciência.

Diferentemente de Heller, Lefebvre (1991) não vê a ciência em oposição ao cotidiano e nem como ferramenta libertadora do homem enraizado na vida do dia a dia. Assim, a sociedade tecnocrata, cientificista, seria a responsável pela fragmentação da vida cotidiana, o que geraria, por sua vez, a sua banalização. $\mathrm{Na}$ sociedade contemporânea, programada e "espetacularizada", a vida cotidiana é 
fragmentada em diferentes cotidianidades. Esses fragmentos, cotidianidades programadas, acomodam-se como peças de um jogo. Cada uma delas pressupõe uma soma de organizações e de instituições, exploradas de maneira racional. Por meio de uma racionalidade ideológica, as questões políticas e econômicas influenciam a dinâmica da cotidianidade na sociedade contemporânea. Ou seja, segundo o autor, uma sociedade industrial tecnocrata, que privilegia o crescimento econômico com a supervalorização da técnica racionalizada pelo discurso cientificista, transforma a vida cotidiana em diferentes cotidianidades. Nesse sentido, a cotidianidade se caracterizaria por sua irreflexão diante da ordem social instituída.

A sociedade capitalista contemporânea divide e organiza a produção de bens materiais de consumo e as relações de propriedade determinam o emprego do tempo diário, sendo tudo legitimado por uma cientificidade. Como afirma Lefebvre (1991), o conhecimento científico racionaliza as condições sociais e materiais para existência na vida cotidiana. A administração do cotidiano dispõe os mecanismos de produção da existência social de forma racionalizada. Um exemplo dessa administração está no emprego coerente e lógico do tempo produtivo. No estudo da vida cotidiana, é possível vislumbrar o ponto de intersecção entre a ciência e o cotidiano, em que a ideologia muitas vezes mascara a racionalidade. As condições dadas para a vida cotidiana pela ciência encobrem questões ideológicas que a legitimam.

Ao encontro das ideias de Lefebvre, apresenta-se a posição de Kosik (2002), segundo o qual o conhecimento científico é produzido na busca por respostas para os problemas e fatos que estão presentes na vida cotidiana e não fora dela. Uma questão teórica pode nascer de práticas que formam a realidade do dia a dia, fora das fronteiras das disciplinas científicas, como indica Certeau (2008). Este aponta que, a partir do século XVIII, em nome do progresso, fortaleceu-se a separação entre as artes do fazer e as ciências esboçadas com uma nova configuração do saber. Ele destaca, ainda, que não se trata somente do binômio tradicional teoria e prática, mas de duas operações distintas, uma não discursiva e outra discursiva. Eis a oposição da ciência: práticas articuladas pelo discurso e práticas que constituem o saber-fazer não discursivo.

A semente da cientificidade moderna está em introduzir os variados tipos de saber-fazer no campo da escritura científica, isto é, por meio de uma inversão linguística "impõe-se o esquema fundamental de um discurso que organiza a 
maneira de pensar em maneira de fazer, em gestão racional de uma produção e em operação regulada sobre campos apropriados" (CERTEAU, 2008, p.136). Ao prevalecer e conquistar todos os espaços sociais, a ciência fortalece o poder da técnica em detrimento das práticas sociais que, para serem legitimadas, são cientificizadas. Por meio do emprego indiscriminado de termos científicos, é criada uma língua artificial, com base em jogos táticos entre os poderes econômicos e políticos. Dessa forma, a linguagem prosaica que se torna presente no cotidiano prevalece sobre a poética.

O encontro entre as ciências, lugar dos conflitos onde se formulam problemas concretos da existência social dos seres humanos, se dá no cotidiano. As ciências embaraçadas com seu coeficiente ideológico procuram racionalizar o cotidiano para apreendê-lo e fragmentá-lo. Cada uma delas racionaliza um aspecto, seja o econômico, o histórico, o sociológico, o antropológico ou o psicológico, de um lugar em que são formulados os problemas concretos da produção da existência social humana, dando uma feição científica à cotidianidade. Os fatos cotidianos são recortados e classificados pelos especialistas, conforme padrões e critérios, empíricos ou abstratos, estipulados pelas ciências (LEFEBVRE,1991).

\begin{abstract}
A análise crítica do cotidiano revelará analogias, ao passo que o conhecimento do cotidiano compreenderá uma crítica ideológica e, bem entendida, uma autocrítica perpétua. [...] Além do mais, enquanto reflexão sobre uma realidade parcial da vida social - a cotidianidade [...] a análise não poderá dispensar teses nem hipóteses sobre o conjunto da sociedade (LEFEBVRE, 1991, p.34).
\end{abstract}

Ao valorizar a mensuração e o controle experimental na produção do conhecimento, a ciência moderna estabelece a objetividade como fundamento das proposições científicas e adota o princípio da validade universal, o que leva a pessoa a se abstrair de sua atividade singular de pensar, concebendo a forma científica do conhecimento como um dado a priori. Dessa maneira, para que o conhecimento seja significativo, ele deve atender à forma e ao grau de abstração universal estipulados pela comunidade científica, o que caracteriza um comportamento a-histórico e impessoal. 
A análise que Lefebvre faz sobre o cotidiano indica que não há na vida uma demarcação absoluta entre a ação e o pensamento, a prática e a teoria. $\mathrm{O}$ homem é inapreensível; nenhuma teoria consegue defini-lo plenamente. Esse homem, enfim humano, realiza-se pela ação e na prática, isto é, na vida cotidiana. Ou seja, o homem afirma-se homem na vida de cada dia, na cotidianidade.

Assim, considerar que o cotidiano está restrito ao pragmatismo absoluto e à sua heterogeneidade é concebê-lo como uma categoria universal, imutável, independentemente da cultura e do momento histórico. Ou seja, é como se a vida cotidiana fosse a mesma para o homem que vive em culturas e em épocas distintas, sem considerar os modos históricos de organização social.

Em uma sociedade estruturada em classes sociais, que exige cada vez mais conhecimentos especializados e titulação, o trabalho prático é visto como uma tarefa inferior, enquanto que o intelectual, além de ser reconhecido e valorizado socialmente, é destinado a alguns privilegiados. Entretanto, tanto o pensamento prático quanto o teórico estão presentes nos dois modos de trabalho. Segundo Leontiev (1983), a crença na relação antagônica entre atividades práticas supostamente cotidianas - e teóricas - supostamente científicas - está calcada na divisão social do trabalho.

A sociedade centrada no poder econômico de mercado, definida como monocrônica por Guerreiro Ramos (1981), não possibilita o agir responsável e independente das pessoas. Ela é o local do tempo linear e serial, onde os acontecimentos da vida são analisados por regras de causalidade eficiente e o passado é causa do presente e este causa do futuro. O trabalho toma uma nova forma, na qual a pessoa, reduzida a detentora do emprego, obedece rigidamente a regras de comportamento impessoal no cumprimento de normas administrativas. Não cabe ao detentor do emprego agir e deliberar em conformidade com o seu pensar crítico, responsabilizando-se por suas escolhas. Ao priorizar a economia, essa forma de sociedade não enseja a vigência de outros modos de organização social (TUNES; BARTHOLO; TUNES, 2006).

Entretanto, para Guerreiro Ramos (1981), é possível a existência de uma sociedade policrônica, onde as condições de realização da vida e das capacidades humanas se dariam com a vigência de três modos de organização da sociedade econômica, isonômica e fenonômica - e da experiência de três tipos de tempo serial, convivial e de salto. Ou seja, seriam espaços que privilegiariam os vínculos 
pessoais e o compromisso com a vida em comunidade, em que as pessoas exerceriam atividades que visassem a objetivos intrínsecos à própria atividade, diferentemente do que acontece com a sociedade monocrônica, que atende a critérios de eficiência instrumental. Na organização isonômica, o tempo é o convivial, o da primazia do presente, que possibilita o enraizamento do homem em sua vida, de maneira a conduzi-la com autonomia, responsabilidade e compromisso com a comunidade. Já nos espaços fenonômicos, o tempo experienciado é o do salto, de ruptura, característica do desenvolvimento, em que se faz presente a imprevisibilidade e a criação. É a possibilidade de a pessoa conduzir sua vida em conformidade à sua opção pessoal e não ao cumprimento de regras preditivas (TUNES, BARTHOLO; TUNES, 2006).

É possível supor, então, que a vivência em uma sociedade policrônica tenha sido possível em um momento anterior à divisão social do trabalho, da transformação da vida comunitária em sociedade estruturada por princípios econômicos e normatizada pela primazia da razão. Houve um tempo em que o cotidiano exerceu um papel constitutivo preponderante na vida das pessoas, quando a atividade de pensamento era vista em sua unidade, coesão das formas de trabalho intelectual e prático.

É no cotidiano, pelo trabalho, que as transformações no curso da História acontecem, no conjunto dos fatos cotidianos, na ideia mais complexa e mais rica do pensamento à ação. Com a divisão do trabalho em parcelas e funções, funde-se o individualismo, a valorização da técnica e da especialização. Nesse modo de produção, os indivíduos desenvolvem uma individualidade privada, vazia e abstrata, desvinculada de sua relação singular e universal com a vida cotidiana. Torna-se uma vida privada da realidade, dos laços com o mundo concreto, em que os indivíduos dividem-se em tendências individualistas. Dessa forma, o indivíduo compreende os elementos constitutivos da vida como contraditórios: o trabalho e o repouso, a vida pública e a privada, a intimidade e as circunstâncias externas, as chances e a fatalidade, o ideal e o real e o maravilhoso e o cotidiano (LEFEBVRE, 1947).

A relação econômica, científica e tecnológica na modernidade promoveu a desarticulação entre o produto do trabalho e o próprio trabalhador, o conhecimento necessário à produção e o tempo e modo de vida. O trabalhador viu-se reduzido a uma força de trabalho mercantilizada e sua existência foi trocada pelas condições de assalariamento (BARTHOLO, 1986). 
[...] os trabalhadores atomizados são "aquartelados" em unidades produtivas com fins de potencializar sua disponibilidade e exploração. [...] todos os tempos e movimentos envolvidos nas ações executivas das tarefas produtivas passam a ser objeto de decomposição analítica, de normatização e padronização [...] (BARTHOLO, 1986,p.40).

Em parceria com essa nova forma de organização produtiva, que privilegia a economia monetária, está a ciência comprometida ideologicamente com o mercado que se perpetua por meio de instituições sociais em concordância com os princípios mercantis. "O pensamento conceitual-abstrato da ciência moderna é um produto de suas condições de formulação" (BARTHOLO, 1986, p.49). Ou seja, o conhecimento teórico é figurado como fruto exclusivo da razão, do trabalho intelectual desvinculado do trabalho prático, configurando o universalismo e a generalidade abstrata. Por sua vez, o conhecimento cotidiano é concebido como espaço empírico e de prática experimental, que necessita ser abstraído para elaboração de juízos objetivamente verdadeiros, formulações teórico-científicas.

Certeau (2008, p. 65) assim complementa:

Desde que a cientificidade se atribuiu lugares próprios e apropriáveis por projetos racionais capazes de colocar zombeteiramente os seus modos de proceder, os seus objetos formais e as condições de sua falsificação, desde que ela se fundou como uma pluralidade de campos limitados e distintos, em suma, desde que não é mais do tipo teológico, a ciência constituiu o todo como o seu resto, e este resto se tornou o que agora denominamos cultura.

Outra característica apontada por Heller a respeito do cotidiano é o preconceito. Para a autora, o homem absorvido inteiramente pela vida cotidiana não se desenvolve plenamente; aprende apenas os elementos da cotidianidade $\mathrm{e}$ não transita autonomamente ${ }^{18}$ em diferentes ambientes da sociedade, isto é, para

\footnotetext{
${ }^{18}$ O conceito de autonomia adotado por Agnes Heller consiste na escolha e na opção, dentre muitas alternativas, marcadas pela individualidade da pessoa. Ou seja, por ter consciência de si e das circunstâncias, o indivíduo faz sua escolha (HELLER,1994).
} 
além da dimensão de seu mundo. No cotidiano, afirma Heller (2004), predominam atividades voltadas para a reprodução do humano particular. As ideias fragmentadas e os juízos de orientação social subsidiam as atitudes no cotidiano. Os afetos fé e confiança desempenham papel de mediação; o afeto confiança baseia-se no saber e na experiência do humano-genérico e a fé, afeto do preconceito, nasce da particularidade individual, das necessidades e motivações atendidas.

A ultrageneralização, para a autora, é inevitável na vida cotidiana, dada a heterogeneidade de atividades que esta impõe, exigindo uma prontidão para um agir que seria impossível, se dependesse apenas de conceitos fundados cientificamente. Toda ultrageneralização é um juízo provisório ou uma regra provisória de comportamento porque é antecipação da ação e pode não se confirmar na prática. Ou seja, todos os juízos são provisórios, dado o caráter de opinião próprio do saber cotidiano.

Heller (1994, 2004) afirma ainda que a ação prática, presente na vida cotidiana, está calcada no senso comum, no conhecimento não fundamentado pela ciência. Para a autora, o senso comum não possibilita o desenvolvimento do humano genérico, uma vez que o homem, preso ao cotidiano e guiado por esse modo de conhecimento, tende ao pré-julgamento. Como critério para ação, que pode ou não ser confirmado, os juízos provisórios podem se modificar em decorrência da atividade. Portanto, a ultrageneralização pode ou não ser confirmada pela prática e pode também se constituir como preconceito. Se a ele aderir o afeto confiança, não se trata mais de preconceito. Mas, se a ele aderir a fé que, para Heller, em relação à confiança, é menos permeável à experiência, à moral e à teoria, significa, então, preconceito: "os juízos provisórios que se enraízam na particularidade e, por conseguinte, se baseiam na fé são pré-juízos ou preconceitos"(2004,p.35).

Diferentemente do que Heller afirma ser o senso comum, que constitui o conhecimento cotidiano, Arendt (2009a, 2009b) argumenta que o senso comum é o espaço de atividades em que a pessoa tem sua permanência na mundanidade. Ele compreende o que é comum a todo homem, propicia o exame da condição de expressão da existência humana, qualidade política, que possibilita a convivência em sociedade. A autora alerta para 0 fato de que o agravante está no recrudescimento da superstição e da credulidade que fortalecem ideias préconcebidas. Isso nos leva a pensar que o preconceito não está atrelado simplesmente à presença ou não de conhecimento, como sugere Heller. 
Os preconceitos, para Agnes Heller (2004), servem a certos interesses que visam a consolidar e manter a estabilidade e a coesão social. Em sua maioria, são produtos da classe dominante que objetivam a manutenção da estrutura social como forma de garantir a realização de seus interesses e benefícios. Ou seja, os preconceitos são úteis à ideologia hegemônica que, em função do conservadorismo, comodismo e do conformismo presentes no cotidiano, afastam o humano-particular da atividade práxis, própria do homem-genérico. O homem propenso ao preconceito tende a guiar-se em conformidade com a estereotipia de grupo, posto que ele tem dificuldade para corrigir um juízo provisório com base em nova experiência e no pensar a respeito da concepção adotada. Ao encontro das ideias de Heller (2004), Guimarães (2000) argumenta que a fé está relacionada com o sentimento de certeza sem uma explicação racional a respeito da ação a ser realizada, justificada por uma intuição que a certifica.

Heller (2004) admite a possibilidade da existência do preconceito fora do âmbito do cotidiano, por exemplo, na ciência e na arte, mas entende que ele não procede dessas esferas. Isso porque tanto a ciência como a arte rompem com a espontaneidade do pensamento cotidiano: a primeira, pelo seu caráter desantropomorfizador, e a segunda por ser autoconsciência e memória da humanidade. Arte e ciência são, para a autora, formas de elevação acima da vida cotidiana que produzem objetivações duradouras e genéricas. Na ciência, os juízos são provisórios até o momento em que uma hipótese é confirmada como verdade, diferentemente da vida cotidiana, que concebe uma hipótese ou uma opinião como um saber.

Contudo, Heller (1994, 2004) desconsidera o fato de que, em diferentes momentos da História é possível encontrar, no desenvolvimento da ciência, o preconceito. Em seus estudos, Gould (2003) ressalta que a ciência é produzida por seres humanos e, por isso, está sujeita ao contexto político, uma vez que é uma atividade de cunho social. A ideia de que a ciência é isenta de questões ideológicas e de que os cientistas estão livres das convenções culturais é uma falácia. Um exemplo disso é a crença na ideia de que "os papéis sociais e econômicos refletem fielmente a constituição inata das pessoas" (GOULD, 2003, p.4). Ou seja, o determinismo biológico explicaria a convicção de que a capacidade humana é inata e justificaria, assim, o fato de que algumas pessoas ocupem lugar de destaque social e de poder sobre outras, como, também, a convicção de que existem raças 
superiores e inferiores, que foi respaldada por pesquisas científicas comprometidas ideologicamente. Teorias foram desenvolvidas com base no uso de instrumentos de medida de inteligência e por meio de pesquisas genéticas para afirmação do poder dos genes. A prática científica vem justificando atitudes preconceituosas a respeito da superioridade de algumas etnias sobre outras, como o movimento eugenista, que começou no século XIX.

Perdura atualmente a busca por atender aos padrões de desenvolvimento humano, de homem e mulher, e de modo de vida estabelecidos pela ciência. A pessoa que apresenta uma constituição psicofisiológica não convencional é vista como ser de falta, um deficiente, por exemplo. Tunes (2007) afirma que, por meio da razão médica, o diagnóstico instaura um rótulo na pessoa, que deixa de ser identificada por seu nome próprio. Assim diz: "o nome próprio não é conceitual, [...] o rótulo é palavra-ato, já preconceito" (p.54). Esse aspecto é complementado por Bartholo (2007, p.44-45):

\begin{abstract}
Os desafios éticos contemporâneos referem-se a um contexto em que se afirmam duas grandes pretensões. De um lado, a de identificar o ato de conhecer com o empenho por ordenar uma totalidade como um sistema, fruto da captura conceitual da verdade, como só sabido por obra dos saberes do sujeito. [...] o preconceito é por definição o já sabido por mim por um saber prévio e independente a qualquer escuta interpessoal.
\end{abstract}

Em seu exame sobre o preconceito, Cavalcante (2004) propõe uma análise ética. Para ela, "o preconceito refere-se à vida na qual ele está imbricado concretamente. Assim, sua análise não pode se distanciar da realidade, que é viva, dinâmica e contraditória" (p.25). Não se trata de presença ou ausência do conhecimento em si, mas de informações equivocadas, estruturadas nos moldes da razão científica, que originam prejulgamentos. Na perspectiva da ética inter-humana, o preconceito surge quando a condição humana é submetida aos imperativos da razão científica.

Em sua análise sobre a cotidianidade, Heller (2004) aponta, também, a alienação como uma de suas características. Para ela, a alienação dá-se pela dogmatização das formas de pensamento cotidiano, pelo predomínio de atividades voltadas para a reprodução do humano-particular, impossibilitando a pessoa de se 
apropriar das objetivações genéricas e das estruturas de pensamento e ação. $O$ homem e o mundo se afastam na medida em que os interesses pessoais imperam sobre as questões do coletivo social. Ou seja, o homem volta-se apenas à satisfação de suas necessidades pessoais em detrimento das atividades, de caráter genérico, socialmente necessárias. Além disso, a autora assevera que a confluência de fatores como a divisão social do trabalho, a propriedade privada e o nascimento das sociedades de classe principiam o processo de alienação do homem-particular.

Lefebvre (1947) tem uma visão diferenciada do processo de alienação. Para ele, ela se desenvolve quando a atividade humana está desvinculada da realidade concreta da vida. Como ele diz: "A alienação se descobre na vida de cada dia, na do proletário e mesmo na do pequeno burguês ou capitalista (com a diferença de que esses últimos se tornam os cúmplices do poder que os desumaniza)" (p.108-109).

À luz do pensamento helleriano, Duarte (2007) afirma que, quando o desenvolvimento humano-genérico não acontece, a vida da pessoa é regida pela cotidianidade do humano-particular. Na opinião de Heller (2004), o cotidiano, que aponta para o sentido do humano-particular, encontra-se em um polo distinto ao da ciência e da arte, as quais desenvolvem o humano-genérico. Heller relaciona a heterogeneidade à cotidianidade, objetivação particular, e a homogeneidade à ciência e arte, objetivação genérica. Ela não nega a particularidade individual de artistas e cientistas, entretanto, admite a possibilidade de sua suspensão durante a produção. Vale conferir o que diz com suas próprias palavras, no trecho transcrito a seguir:

A homogeneização em direção ao humano-genérico, a completa suspensão do particular-individual, a transformação em "homem inteiramente", é algo excepcional na maioria dos seres humanos. Nem sequer nas épocas ricas em grandes comoções sociais existem muitos pontos críticos desse tipo na vida do homem médio. A vida de muitos homens chega ao fim sem que se tenha produzido nem um só ponto crítico semelhante. A homogeneização em direção ao humano-genérico só deixa de ser excepcional, um caso singular, naqueles indivíduos cuja paixão dominante se orienta para 0 humano-genérico e, ademais, quando têm a capacidade de realizar tal paixão. Esse é o caso dos grandes e exemplares moralistas, dos estadistas (revolucionários), dos artistas e dos cientistas. De resto, a respeito do grande estadista, do revolucionário profissional, do grande artista, do grande cientista, deve-se afirmar que não apenas sua paixão principal, mas também seu trabalho principal, sua atividade básica promovem a elevação ao humano-genérico e a implicam em si mesmos. Por isso, para tais 
pessoas, a homogeneização em "homem inteiramente" é elemento necessário de sua essência, da atividade básica de suas vidas. Mas não se deve esquecer que 0 artista, o cientista, o estadista não vivem constantemente nessa tensão. Possuem também, como todos os outros homens, uma vida cotidiana; o particular-individual manifesta-se neles, tal como nos demais homens. Tão-somente durante as fases produtivas essa particularidade é suspensa; e, quando isso ocorre, tais indivíduos se convertem, através da mediação de suas individualidades, em representantes do gênero humano, aparecendo como protagonistas do processo histórico global (p.28-29 - Itálicos da autora).

Com isso, Heller aponta diferenças radicais entre atividades cotidianas e não cotidianas, ressalta a importância da suspensão da cotidianidade por meio da arte e da ciência e destaca que a moral e o trabalho contribuem para a passagem do singular ao humano genérico. Ela afirma que a ciência, a arte e a filosofia são "objetivamente genéricas do conhecimento e autoconhecimento humanos" (HELLER,1994, p.188), ou seja, constituem partes integrantes da práxis humana, visão teórica da realidade. Tanto a ciência como a arte e a filosofia nasceram das necessidades da vida cotidiana e, posteriormente, se fizeram autônomas, como esferas de objetivações específicas e genéricas.

Ao encontro das ideias hellerianas, Netto, em seu texto Para a crítica da vida cotidiana, afirma que, ao suspender a cotidianidade, o homem a ela retorna transformado, percebendo-a como espaço para humanização. "A dialética cotidianidade/suspensão é a dialética da processualidade da constituição e do desenvolvimento do ser social" (CARVALHO; NETTO, 2010, p.71).

Diferentemente de Heller, Martins (2010) adota o argumento de que o desenvolvimento do humano-genérico está relacionado com o tempo forjado no plano da vida material e cultural, ou melhor, no limite da compreensão racional e objetiva, que traz em si as contradições do processo histórico que a reproduz. Sua afirmativa contrapõe-se à ideia de que a ciência e o cotidiano são dicotômicos. Para o autor, a História é vivida e decifrada no cotidiano, que não pode ser retratado apenas como rotinas e banalidades de todos os dias. Carvalho, em seu texto $O$ conhecimento da vida cotidiana: base necessária à prática social (CARVALHO; NETTO, 2010) complementa essa ideia, ao destacar que o homem da vida cotidiana é, ao mesmo tempo, singular e genérico e que o enfoque da análise deve estar na 
passagem da particularidade e genericidade à unidade consciente do particular e do genérico.

Na visão de Lopes (1999), a suspensão da vida cotidiana não passa de um limite absoluto forjado entre a arte e a ciência e o pensamento cotidiano. A autora argumenta, ainda, que os artistas e os cientistas vivem a cotidianidade e, portanto, suas obras partem do cotidiano e a ele retornam.

[...] nenhum homem consegue identificar-se com a atividade humanogenérica de forma a alcançar um desligamento absoluto da cotidianidade, assim como não há nenhum homem que viva tão somente na cotidianidade, mesmo quando ela o absorve preponderantemente.[...] não é possível traçar uma linha divisória rigorosa e rígida entre o comportamento cotidiano e o não-cotidiano. $O$ indivíduo é sempre unidade vital de particularidade e genericidade. A extensão e a proporção entre o particular e o genérico variam de indivíduo para indivíduo, em função das relações sociais, das quais é parte integrante e atuante (LOPES, 1999, p.140).

O processo de mudança de relação da pessoa com o mundo, da particularidade à genericidade, implica um novo modo de se relacionar com o próprio cotidiano. O fato de a pessoa desenvolver uma atividade humano-genérica não significa que o pensamento cotidiano esteja ausente; implica, sim, o aprofundamento e o enriquecimento do conhecimento da esfera cotidiana. O homem é uma unidade e, como tal, se relaciona com diferentes esferas da vida. Não se pode esquecer que as atividades da vida - intelectuais, científicas, técnicas, práticas e de sobrevivência - constituem o cotidiano. São as relações sociais e o enraizamento cultural que caracterizam diferentes cotidianidades de acordo com o modo de vida da pessoa, na vivência diária, enfrentando conflitos e desafios, tomando decisões diante das adversidades e imprevistos que surgem no dia a dia. Ou seja, o trânsito do homemparticular ao homem-genérico caracterizará a cotidianidade (LOPES, 1999).

A cotidianidade capturada pela lógica da acumulação, mensuração e mediada pelo valor de troca é invadida pelo tempo linear, tempo do homem desencontrado consigo mesmo, que se torna produto de seu produto, transfigurado em objeto, em contradição com as características próprias da vida privada. Dessa forma, o cotidiano pode gerir uma cotidianidade de vida sem estilo, uma vez que a finalidade do trabalho na sociedade contemporânea vem sendo gradativamente 
descaracterizada. O consumo de mercadorias com fins de atender a necessidades forjadas pelo sistema econômico está ligado às estruturas sociais, públicas e privadas (MARTINS, 2010).

Atrelado à lógica de mercado, o Estado reconhece na vida cotidiana o espaço de controle e manipulação do homem comum, de maneira a não só aliená-lo pelo consumismo, como também deixá-lo dócil, produtivo e abdicado de sua condição humana. "[...] não são as relações de produção, mas sim as relações sociais de dominação e poder que têm sua primazia na modernidade" (CARVALHO; NETTO, 2010, p.22).

Até o capitalismo de concorrência e seu desdobramento para um mundo de mercadorias, a cotidianidade não estava reduzida à atividade diária no que tange à produção de objetos de consumo. A criação de produtos vem ocupando o processo de criação na sociedade mercadológica. Lefebvre (1991) alerta para o fato de que o homem moderno que exalta a modernidade não passa de um homem de transição de homo faber para homo quotidianus, um homem autômato que segue a programação instituída pela sociedade de mercado. Ou seja, o homem perde "até sua qualidade de homo" (p.204) e aliena-se. Nesse processo, a qualidade libertária do homem se esvai na cientificidade dinâmica do cotidiano regulado e programado pela ideologia mercantil.

A produção industrial e a tecnicidade dão as condições de uma produtividade sem limites com a automatização das atividades produtoras. Uma consequência decorrente é a abundância produzindo novas carências, ou seja, o excesso e a variedade de novos bens de consumo geram necessidades antes inexistentes. Na sociedade da abundância, o lazer, assim como já foi o trabalho, é visto como uma necessidade; entretanto, por ser programado, perde sua espontaneidade. O emprego do tempo, com sua fragmentação em tempo de lazer, tempo do trabalho profissional e o tempo das exigências impostas, é outro fator que intervém na organização da vida cotidiana (LEFEBVRE, 1991).

A tecnocracia tem como álibi as aplicações da técnica à vida social; ela própria é um álibi, ou seja, o álibi dos verdadeiros dirigentes da economia e da política. A sociedade [...] se transformaria sob nossos olhos em sociedade científica: aplicação racional do mais alto saber, conhecimento da matéria e conhecimento da realidade humana. Essa "cientificidade" justifica 
a racionalidade burocrática, estabelece (ilusoriamente) a competência dos tecnocratas. Tecnicidade e "cientificidade", tanto uma quanto a outra transformadas em entidades autônomas, remetem uma à outra, se justificam reciprocamente, servindo cada qual de álibi para a outra (LEFEBVRE,1991,p.58).

A perda das condições materiais de expressão das tradições culturais e a ausência de "participação real, ativa e natural na existência de uma coletividade que conserva vivos certos tesouros do passado e certos pressentimentos do futuro" (WEIL, 2001, p.43) propiciam o desenraizamento da vida humana. O cotidiano, em sua práxis coletiva e familiar, é o espaço de criação, de resistência e de revolução. O enraizamento do homem é no cotidiano. Como afirma Bosi (2003, p.187), "esvaziando o trabalho de significação humana, ele esvazia o sentido das lembranças e aspirações". Tal esvaziamento com os seus modos de produção industrial em sua cultura repetitiva e confinada promovem as condições de formas de adaptação desenraizadas.

Portanto, pode-se afirmar que a vida em sociedade constitui o cotidiano, espaço de enfrentamento de tensões e conflitos que apresenta um tempo e um ritmo próprios, demarcados pelo modo de produção e pela organização social. Para Kosik (2002), em diferentes momentos da história, a vida cotidiana estrutura-se de maneira singular, em que todos participam independentemente do status social. A história da humanidade é construída no desenrolar das atividades desenvolvidas pelo homem no cotidiano, conforme ele diz: "A cotidianidade é o pedestal e o material da História: ela suporta a História e a nutre, mas em si mesma não tem história" (p.82).

Kosik (2002) propõe entender o cotidiano de forma articulada com a variabilidade e a ação histórica. Tratá-lo apenas pelo aspecto da automatização e da mecanização poderia conduzir ao seu esvaziamento, à sua banalidade, à religiosidade da produtividade e à mistificação da História. A margem que separa o que é ou não passível de automatização constitui um processo histórico. $\mathrm{Na}$ cotidianidade, o homem estabelece relações entre as atividades que desenvolve. Sua experiência com os acontecimentos da vida diária torna sua realidade seu próprio mundo.

Certeau et al. (1996) compartilham do pensamento de Kosik (2002) e afirmam que o cotidiano compreende o viver a cada dia, dia após dia, do amanhecer, com os encargos e afazeres que a vida traz consigo, ao anoitecer com a 
fadiga e com a história íntima de cada um guardada na memória. Para cada época histórica e em diferentes sociedades, complementa Lefebvre (1991), a vida cotidiana apresenta-se de uma determinada maneira, em diferentes estilos e culturas.

\begin{abstract}
O cotidiano é aquilo que nos é dado cada dia (ou que nos cabe em partilha), nos pressiona dia após dia, nos oprime, pois existe uma opressão do presente. Todo dia, pela manhã, aquilo que assumimos, ao despertar, é o peso da vida, a dificuldade de viver, ou de viver nesta ou noutra condição, com esta fadiga, com este desejo. O cotidiano é aquilo que nos prende intimamente, a partir do interior. É uma história a meio-caminho de nós mesmos, quase em retirada, às vezes velada (CERTEAU et al., 1996, p. 31).
\end{abstract}

Como já foi mencionado, sob a necessidade do controle, a vida é concebida de forma restrita à rotina de um cotidiano planejado e organizado conforme as normas e os padrões ideológicos de uma sociedade moderna cientificista. A convicção de que a ciência está acima da trivialidade e isenta de qualquer parcialidade ideológica ratifica a crença na ideia de que tudo ela é capaz de elucidar, explicar e justificar e de que o cotidiano é simplesmente a rotina do dia a dia, com seus dramas e conflitos, a sobrevivência.

A concepção de que o pensar está separado do fazer e de que o trabalho prático está desarticulado do intelectual promove o entendimento de que a atividade prática é empobrecida e apenas mecânica e que a intelectual é a superação da banalidade.

O inesperado, a surpresa e a imprevisibilidade constituem a vida cotidiana. Ela compreende a riqueza do desconhecido, que escapa à consciência plena. Portanto, ela é inapreensível, pois está em constante criação e recriação. É na vida cotidiana que o homem se enraíza e se realiza. Como afirma Arendt (2009a), cada pessoa é única e "o fato de que o homem é capaz de agir significa que se pode esperar dele o inesperado, que ele é capaz de realizar o infinitamente improvável" (p.191).

O estudo de Lefebvre $(1947,1991)$, em contraposição às ideias hellerianas, aponta para o fato de que a vida cotidiana se compõe de começos, recomeços, renascimentos e surpresas. $O$ cotidiano apresenta caráter repetitivo em 
ações do dia a dia, oculta o misterioso e o admirável, compreende um conjunto de atividades em aparência modestas, de produtos e de obras, um campo de renovação simultânea, composto de momentos, necessidades, trabalho, diversão, passividade e criação. Ele se constitui no domínio de atividade produtora e criadora, que se desenvolve em um processo dialético de produção, reprodução e de retomada de seus elos constitutivos. É na vida cotidiana que se situa o núcleo racional, o centro real da práxis. Como Lefebvre (1991, p.47) diz: "O homem será cotidiano ou não será".

Os fatos humanos estão no cotidiano e é nele que a ciência busca seu material de estudo. Lefebvre (1947, p.52-53) afirma que "em vários domínios da ciência, as descobertas importantes são realizadas pelo estudo de objetos humildes, banais, cotidianos, insignificantes (na aparência)". O cotidiano possibilita, assim, as condições para o desenvolvimento da consciência do homem.

[...] o pensamento verdadeiro passa, metodicamente, da escala individual à escala social [...]. Assim, ele chega a uma noção científica do trabalho social. A ferramenta, o gesto do trabalhador - camponês, artesão, operário - aparece, então, como um elemento, como um momento do trabalho total; e desse trabalho total nós sabemos que ele modificou, transformou a face do mundo (LEFEBVRE,1947, p.57). O que faz de um homem um ser social e humano - e não apenas um ser biológico, que nasce, cresce e morre imerso na vida natural é seu trabalho, sua atividade social, seu lugar, sua situação no conjunto social, ao mesmo tempo o limite e a margem em nossa organização atual do trabalho ( p.79).

Destarte, a ideia de que a vida cotidiana está restrita à rotina do dia a dia não se sustenta. Afirmar que há dois grupos de conceitos, cotidianos e científicos, supõe que o conhecimento científico esteja fora da vida cotidiana, o que é questionável. Conforme já foi dito, Vigotski afirma que os conceitos cotidianos têm sua origem no dia a dia da vida e que os científicos originam-se na instrução formal escolar. A atividade do cientista, seja no laboratório, ou em outros espaços de pesquisa, caracteriza uma cotidianidade, assim como a instrução formal e o frequentar a escola fazem parte do cotidiano das crianças e jovens da sociedade contemporânea. Diferentes cotidianidades constituem a vida cotidiana. A vida cotidiana é o estar no mundo em toda sua diversidade. O cotidiano não é imutável, 
tem um caráter histórico. Há uma infinidade de atividades que constituem a vida humana; consequentemente, infinitos cotidianos.

Assim, os conceitos denominados de científicos têm origem numa atividade do cotidiano. Então, quanto à sua gênese, ele não se diferencia dos demais conceitos. Quando Vigotski afirma que os conceitos científicos surgem e se formam no processo de instrução escolar, ele pretende identificar a atividade em que esse tipo de pensamento por conceito se desenvolve. Ele desconsidera que na atividade do cientista é que se originam os conceitos científicos, pois tal atividade está orientada por um problema e pela indagação a respeito desse problema, com postura investigativa.

$\mathrm{Na}$ transposição didática, que acontece na instrução escolar, são considerados o saber sábio, fruto da atividade científica; o saber a ensinar, que compreende as propostas curriculares; e o saber ensinado, que envolve a comunidade escolar. Assim, o sistema didático não atende à complexidade da organicidade de uma estrutura teórica (NEHRING et al., 2002).

Quando Vigotski trata dos conceitos cotidianos, ele afirma que esses se originam nas atividades do dia a dia, como se o cotidiano fosse homogêneo, o que não é verdadeiro. Se o conceito chamado científico é também cotidiano, que razões existem para ele ser destacado dos demais, como fez Vigotski? Essa questão será examinada no próximo capítulo. 


\section{CIÊNCIA, COTIDIANIDADE E VARIABILIDADE CONCEITUAL}

Neste capítulo, são examinados alguns aspectos filosóficos, epistemológicos e psicológicos da ciência, suas implicações no modo de vida contemporâneo e algumas razões que sustentam o lugar de destaque dos conceitos científicos.

Em seus estudos epistemológicos a respeito da razão, das causas e dos processos de mudança conceitual, Stephen Toulmin $(1973,1977)$ defende a ideia de que o desenvolvimento histórico do conhecimento e da compreensão humana acontece na vida cotidiana. A ciência é para ele um empreendimento social e coletivo enraizado na cotidianidade e consiste em uma população histórica de conceitos e teorias logicamente independentes, cada um dos quais com sua história, sua estrutura e suas próprias implicações. Toulmin (1973, p.113) adverte que a "ciência não funciona como um ordenador intelectual. É uma fatia da vida". De forma similar, Flusser (1979) entende que, se o mundo é realidade humana, homem e mundo não podem ser compreendidos como entidades separadas e desvinculadas. Assim, a ciência - empreendimento humano - articula-se, necessariamente, com o concreto estar no mundo, que é arte e engajamento político.

Ao encontro dessa visão de ciência, Vigotski (2004) assevera que o conhecimento científico é apenas um dos aspectos da realidade. Ou seja, a verdade científica não é a verdade da realidade. Por ser uma construção viva, a ciência enfrenta as contradições e as mudanças presentes na história. Portanto, ela não constitui um processo único que transcende o tempo e o espaço. Ele ressalta que a realidade constitui o objeto da ciência e alerta para o fato de que é impossível estudar os conceitos sem considerar as realidades representadas por eles. Entende que "o estudo científico é trabalho metódico sobre a própria ciência, na medida em que essa avança" (p.316, 317). As mudanças e o desenvolvimento das ideias, as categorizações e as deduções estão atreladas às particularidades dos fatos estudados pela ciência, levadas aos limites lógicos e à sua máxima generalização. As tendências sociais, as causas sociais e os interesses ideológicos presentes no estudo científico são elucidados pelos princípios filosóficos. O fato científico surge na vida social e a ela deve retornar transformado (VIGOTSKI, 2004). 
Toulmin (1973) compartilha com Vigotski a ideia da articulação entre filosofia e ciência e afirma que esse modo de ver não é novo; já existia em Platão e Aristóteles, ainda que cada um a seu modo. Para Toulmin (1977, p.20), ambos os filósofos viam harmonia entre ciência e filosofia e eles "não se referiam à natureza, senão à natureza inteligível, não a um mundo que o homem pudesse ou não compreender, senão a este mundo como objeto da compreensão do homem".

Contudo, com o advento da ciência moderna, ocorreu o distanciamento entre esta e a filosofia, que se ampliou cada vez mais no decorrer dos séculos. Tal fato foi agravado com a fragmentação da ciência em várias disciplinas. Com essa fragmentação, o reconhecimento da autoridade intelectual ficou restrito a cada disciplina isolada com sua própria lógica, imparcialidade e verdade. Como diz Toulmin (1977, p. 58)

\begin{abstract}
A medida filosófica da racionalidade de um homem converteu-se na faculdade para reconhecer a validade dos axiomas, as implicações formais e as necessidades lógicas das quais dependem as afirmações do sistema autorizado. Nessa perspectiva [...] limitava-se o debate filosófico. Definiu-se o fórum imparcial da razão como um sistema imutável de axiomas ou princípios.
\end{abstract}

Com o distanciamento entre filosofia e ciência, o pensar científico passou a ser um meio para um fim, o cognitivo. Ou seja, a ciência incumbiu-se de determinar o que vale a pena ser conhecido. Dessa forma, o conhecimento é o fim almejado e, uma vez considerado verdade, é admitido como constituinte do mundo. Como afirma Arendt (1978a), a ciência moderna dividiu a vida em dois mundos: o mundo dos leigos, onde prevalece a linguagem cotidiana e o senso comum, que possibilita aos homens comuns se orientarem e compreenderem a realidade; e o dos cientistas, que transitam no mundo da cognição validada. Para a ciência, as questões e os problemas da vida são causados pela ignorância dos leigos. Contudo, Arendt (2009b, p.330) ressalta que os leigos "que levantam questões pré-científicas por ignorância" são os que alimentam a ciência.

A autora alerta para o fato de que, sob o prisma da ciência moderna, as questões do dia a dia perdem sua expressão de sentido. Segundo ela, após a dúvida instalada por Descartes, o homem não pôde mais confiar "na evidência dos 
sentidos, nem na 'verdade inata' na mente, tampouco na 'luz interior da razão'” (ARENDT, 2009b, p.84, 85), mas apenas naquilo que pode ser recriado artificialmente por meio do experimento organizado pelo cientista. Acredita-se que esses experimentos sejam um meio para alcançar o progresso científico, já que eles ensejam a busca pela verdade. Todavia, eles alcançam apenas a veracidade, que é provisória e poderá ser substituída por outra mais precisa à medida que a ciência prospera. Arendt (1978a) enfatiza que a busca pelo conhecimento transita no mundo do senso comum. Consequentemente, a ciência

não é mais do que um prolongamento imensamente refinado do raciocínio do senso comum no qual as ilusões dos sentidos são constantemente dissipadas à medida que os erros da ciência são corrigidos.[...] A transformação da verdade em simples veracidade resulta primariamente do facto que o cientista continua limitado pelo senso comum por meio do qual encontramos a nossa orientação num mundo de aparências. [...] o raciocínio do senso comum [...] se aventura no reino da pura especulação nas teorias dos cientistas (1978, p.65 e 66).

Toulmin (1977) concorda com Arendt e afirma que o século XX ficou marcado pela busca incansável por distinguir proposições genuinamente científicas de outras. Assim, algumas proposições foram consideradas expressões vazias ou demonstrações de uma atitude religiosa ou ideológica.

A ciência moderna almeja o domínio de um elemento fundante da vida, que é a imprevisibilidade. Tudo deve estar sob controle e tudo deve ser conhecido. Acaba-se, assim, com a possibilidade de o homem de espantar-se e de admirar-se com as questões que constituem a vida humana. O espanto é um acontecimento não produzido, é algo

para ser sofrido, e não para ser feito [...]. O espanto é o ponto de partida do pensar não é nem enigma nem surpresa nem perplexidade; é um espanto admirativo (p.161). É o espanto que impele o cientista para sua tarefa de "dissipar a ignorância"[...]. Daqui que todo o subsequente "desenvolvimento" de teorias que se harmonizam com a compreensibilidade do universo "é num certo sentido uma fuga contínua ao "espanto" (ARENDT, 1978a,p.155). 
Para ela, o cientista não deixou para trás de si apenas o leigo, com sua suposta compreensão limitada, linguagem simples e laica, mas, também, parte de si mesmo, ao valorizar a comunicação em linguagem matemática e desconsiderar outros modos de compreender o mundo. A despeito da linguagem científica e dos experimentos produzidos em laboratórios, na busca da causa das aparências, o cientista não está livre das ilusões e do senso comum, dado que sua atividade está na vida cotidiana.

Com a instituição da autoridade intelectual na ciência, foram dadas as possibilidades para considerar apenas certos argumentos racionais e apenas alguns métodos de investigação como válidos. Os não legitimados são vistos como supersticiosos ou tolos. Entretanto, destaca Toulmin (1977), esses mesmos tidos como tolos, em outros tempos da história, podem ter inspirado convicção e autoridade. O reconhecimento da autoridade intelectual apenas na ciência é criticado pelo filósofo. O autor alega não ser aceitável um argumento baseado na ideia de que haja conceitos e teorias fixos, dado que há mudanças conceituais e que, com base nelas, os cientistas alteram seus repertórios de conceitos explicativos, acrescentando às suas disciplinas novas variantes conceituais. Toulmin adverte que uma demarcação conceitual estrita é incompatível com os objetivos intelectuais das disciplinas, uma vez que estas estão em desenvolvimento, juntamente com todas suas teorias e conceitos específicos, ou seja, a ciência é historicamente situada. Nas palavras de Toulmin (1977, p. 65):

\footnotetext{
Em todas as esferas, o reconhecimento da diversidade conceitual confere ao problema da racionalidade e da autoridade uma embaraçosa sutileza. A exigência racional de um ponto de vista imparcial segue sendo estimulante e legítimo. A opção se mostra ainda entre o exercício de um poder superior ou o respeito pela discussão equânime, entre a imposição autoritária de opiniões ou a autoridade intrínseca de argumentos bem fundados.
}

Para reconhecimento da autoridade intelectual, Toulmin (1977) comenta que foram criados fóruns profissionais de discussão, espaços, também, de ambições intelectuais, que legitimam um conhecimento ou uma novidade conceitual, certificando o seu valor. Na história da ciência, verifica-se que as questões culturais 
e as instituições sociais intervêm no desenvolvimento intelectual, seja provendo incentivos e oportunidades, ou criando obstáculos para o desenvolvimento da heterodoxia intelectual. Entretanto, para o filósofo, a ideia de um fórum de efetivo debate a respeito das questões que permeiam a ciência poderia contribuir para o seu desenvolvimento.

A ciência, para Toulmin, compreende um compêndio de ideias e argumentos, uma população de cientistas e um sistema de instituições em constante relação. Entretanto, as ambições intelectuais filtram muitas ideias e interesses não convencionais, que poderiam contribuir para o desenvolvimento coletivo da ciência, aprovando apenas algumas ideias de interesse de determinado grupo. Ele alerta que os problemas teóricos de uma ciência podem não oferecer perspectiva alguma de inovação se ficarem limitados às linhas de investigação instituídas e legitimadas. Por não se enquadrarem nessas tais linhas, muitos problemas teóricos são considerados imaturos. O juízo científico, afirma ele, deveria estar focado nas possibilidades que uma investigação tem em apontar novas visões conceituais. Como ele diz (1977, p. 311,312), a "história intelectual de uma disciplina científica, a história institucional de uma profissão científica e as biografias individuais dos cientistas, evidentemente, se tocam, interagem e se fundem".

No desenrolar da história da ciência, verifica-se que em cada época é considerado científico o que um grupo distinto assim o determina. A ciência não é um empreendimento absolutamente consensual. Há tensão na comunidade científica, pelas ideias inovadoras e pelo jogo de interesses que está presente no julgamento dos empreendimentos. Os cientistas que não participam dos fóruns de discussão estão na periferia e, portanto, impossibilitados de terem suas propostas de mudanças conceituais reconhecidas pela comunidade científica. Os que trabalham de forma díspar e independente não têm seu trabalho valorizado. Assim, é possível supor que o juízo científico possa estar comprometido.

A questão fundante da ciência, para Toulmin (1977), é o argumento, que pode variar de uma disciplina para outra, assim como a verdade, que apresenta uma qualidade relativa, conforme os contextos históricos e culturais. Argumento, para ele, compreende uma reivindicação, uma posição a ser defendida, estruturada com as razões que a reforçam, com um raciocínio encadeado que articula os motivos à sua justificativa, com suas exceções e com os seus limites. 
A racionalidade de uma ciência não estaria calcada somente em sistemas teóricos correntes em determinados momentos, mas em seus procedimentos que desvelam descobertas e mudanças intelectuais através do tempo. Portanto, ela está articulada, também, com as condições em que as doutrinas se dispõem à crítica e às modificações no passar do tempo. Para Toulmin (1973), a racionalidade científica deveria ir além do interesse doutrinário individual ou de grupos profissionais específicos. Além disso, ressalta, conceber os princípios científicos como verdade de referência absoluta é um equívoco, pois eles são, muitas vezes, irrelevantes para situações reais da vida cotidiana das pessoas. Os aspectos de ordem intelectual $\mathrm{e}$ institucional que constituem a ciência complementam-se no empreendimento racional.

Para análise dos modos filosóficos de reconhecer a diversidade conceitual e a autoridade intelectual, Toulmin (1977) examina o modo absolutista, que nega a história, e o modo relativista, que considera o contexto histórico e cultural de cada época. Segundo ele, esses dois modos estiveram muito presentes no século XIX e, de certa maneira, perduram nos dias atuais. Ele critica a visão absolutista, ao afirmar que nenhum modo formal pode por si só provar sua aplicabilidade. Essa visão desconsidera que a diversidade de conceitos esteja atrelada às complexidades históricas, por entender que os princípios de racionalidade são imutáveis, perduram no tempo e no espaço, refletindo, assim, formas puras de ideias conceituais. Faz também uma crítica à visão relativista generalizada, pois esta abandona a busca por procedimentos racionais que possibilitam comparar conceitos em diferentes épocas históricas, limitando-se a discutir a respeito do desenvolvimento conceitual em termos de causa e efeito.

Toulmin defende a ideia de que a verdade pode apresentar variedade histórico-cultural, no sentido de os conceitos formarem sistemas de pressuposições, estabelecendo relações de significado e não axiomas. Ressalta que o problema da mudança conceitual não foi abordado pelo absolutismo e nem pelo relativismo; ambos igualaram a racionalidade à lógica em sua universalidade e imparcialidade, acreditando que os conceitos devam formar sistemas lógicos não passíveis de crítica racional. Para ele, portanto, o problema persiste independentemente do modo de sistematização das proposições conceituais adotado. Destarte, o caminho a ser seguido deveria ser um intermediário, evitando-se a condução da análise, seja pelo absolutismo, seja pelo relativismo. Em suma, a questão central da análise, para ele, 
está no exame da autoridade intelectual, pois, caso contrário, o enfoque permaneceria na aparência da formalização dos sistemas. O argumento é que daria suporte à autoridade intelectual.

Sendo assim, Toulmin (1977) considera que o conteúdo intelectual da ciência compreende uma população de conceitos organizada em agrupamentos de sistematização lógica, que se modificam no desenvolvimento da ciência, podendo ocorrer substituição de conceitos e métodos explicativos. O exame aprofundado da argumentação e da racionalidade dos procedimentos científicos requer considerar que ocorrem relações não formais entre os conceitos, procedimentos explicativos e métodos de representação ao mesmo tempo. Nas atividades intelectuais científicas estão presentes tanto a impessoalidade dos termos descritos como o caráter humano no exame dos dados.

Como afirma Flusser (1979), a crença na atitude ética e ideologicamente neutra do cientista, sem preconceito e valores, é desumana. Homem e ciência não são entidades separadas; ambos relacionam-se na realidade concreta. A ciência é uma atividade humana em que o indivíduo está comprometido e imerso no mundo. Conforme diz,

\begin{abstract}
O pressuposto da ciência moderna, segundo o qual o cientista é sujeito que transcende o mundo, leva à ideia de um 'cientista ideal', de um sujeito puro que se inclina sobre o seu objeto sem preconceitos e sem valores [...]. Se for reconhecido que o homem está sempre implicado no mundo, e que a sua realidade é exatamente tal implicação, então o cientista puro não é gente, mas espectro ideologicamente invocado. Porque conhecimento não é visão a partir do transcendente, mas um dos aspectos do estar-no-mundo humano (FLUSSER,1979, p.166).
\end{abstract}

Com perspectiva similar, Toulmin (1977) examina como se constituem as disciplinas científicas. Ele destaca que elas se formam pela articulação entre as técnicas explicativas, os conceitos, os problemas teóricos e os aplicativos empíricos. Ao organizarem suas teorias, os cientistas apoiam-se em conceitos que atendem aos fins coletivos da sua disciplina, definidos pelos procedimentos e técnicas adotadas na mesma. Nenhum conjunto de conceitos esgota uma disciplina, apenas representa um corte histórico de um empreendimento em desenvolvimento. Ele 
argumenta, também, que, para compreender historicamente uma disciplina científica, é necessário considerar como se estruturam as relações entre as instituições, as teorias e os procedimentos adotados para as modificações propostas. Além disso, destaca que a transmissão coletiva de um conjunto de conceitos regidos por regras científicas deve considerar os modos diversos de constituição conceitual presentes em espaços sociais. Uma vez aceito o desenvolvimento histórico dos conceitos, é preciso considerar os modos possíveis segundo os quais esses conceitos se modificam nas atividades dos homens. Os conceitos são definidos em termos verbais e suas consequências são institucionais. Ou seja,

a verdadeira medida do pensamento social e político dos homens não reside nas definições formais de seus termos políticos, senão na significação que adquirem como elementos institucionalizados na prática social ou política. As relações entre o pensamento e a prática, na ciência e na política, são muito similares. Em ambos os casos, a aparição de um novo conceito importante é precedida pelo reconhecimento de novos problemas e está associada à introdução de novos procedimentos para abordar esses problemas. [...], os conceitos adquirem significado servindo a fins humanos relevantes nos casos práticos reais (TOULMIN, 1977, p.176,177).

Examinar os problemas da compreensão humana e da racionalidade é considerar dois contextos ao mesmo tempo: o da experiência prática das obras concretas que podem sugerir modos de melhorar a análise filosófica e o da própria análise filosófica, para aprimorar a compreensão prática dos problemas reais. A prática precede e possibilita a teoria, e esta contribui para a análise da experiência direta. Mesmo considerando-se a relatividade dos padrões racionais de conceitos e juízos em relação aos problemas da compreensão humana e da racionalidade, isso não significa cair no relativismo e rechaçar os juízos comparativos a respeito de diferentes contextos (TOULMIN, 1977).

A análise do desenvolvimento conceitual deve centrar-se nas relações entre os conceitos coletivos dos homens e as situações de mudança em que esses conceitos são operados pelo pensamento, postos em prática. Assim, é possível identificar e caracterizar os processos pelos quais as populações conceituais se 
desenvolvem historicamente, como são estabelecidos os critérios práticos de juízos em diferentes empreendimentos e como tais critérios adquirem um caráter obrigatório do qual depende sua autoridade (TOULMIN,1977).

Em seu estudo sobre a variabilidade conceitual, sobre as mudanças e desenvolvimento das disciplinas científicas, Toulmin (1977) salienta a necessidade de se compreender o modo como a racionalidade se aplica ao uso coletivo de conceitos, tendo em vista as atividades e os empreendimentos humanos que podem ser de natureza disciplinar ou de uso coletivo de maior generalidade. Para ele, o que caracterizaria uma disciplina coletiva em seu elemento fundamental seria o reconhecimento de um objetivo ou ideal, de modo que fosse possível identificar os problemas comuns.

O problema da ciência se encontraria nas fronteiras das diferentes disciplinas científicas em articulação com as populações conceituais relacionadas às atividades intelectuais e práticas. Toulmin (1977) salienta, também, o alcance do empenho interdisciplinar para o desenvolvimento da ciência e afirma que os limites rígidos entre as disciplinas da ciência comprometem a autoridade intelectual. Tais limites podem corroborar uma das problemáticas conceituais, que é a falta de integração entre conceitos e procedimentos explicativos dos diferentes campos, contribuindo para a fragmentação da ciência. O êxito na integração permitiria desmantelar as barreiras entre as disciplinas consideradas de modo separado e independente e contribuiria, assim, para o estudo das mudanças conceituais que ocorrem em uma mesma disciplina, bem como possibilitaria novas proposições conceituais.

Toulmin (1977) propõe eliminar a dicotomização entre conceitos científicos e cotidianos; destaca a necessidade de considerar ambos no âmbito de uma só teoria, em que os princípios subjacentes seriam aplicados a todos os conceitos. Os conceitos intelectuais de ordem prática constituem a trama comum do pensamento ordinário e são considerados simples e autoexplicativos. Entretanto, afirma o teórico, são, na verdade, mais complexos e necessitados de explicação.

Ainda segundo Toulmin (1977), é o empreendimento ou a atividade racional que requererá determinados conceitos e procedimentos para o exame da questão. É preciso compreender como os empreendimentos racionais articulam-se aos sistemas conceituais relacionados às atividades intelectuais e práticas. Não cabe considerá-los como conceitos opostos, mas como produto de um 
desenvolvimento histórico-cultural, isto é, resultado do enfrentamento de sucessivas respostas do homem aos problemas que envolvem procedimentos aritméticos, lógicos e linguísticos. Por enfrentarem exigências contextuais distintas, os conceitos se desenvolveriam em ritmos diferentes; haveria, assim, uma variabilidade conceitual.

Em síntese, a visão de Toulmin sugere que a população conceitual não é homogênea. Ou seja, a ciência não é fruto do transcendente, mas é um empreendimento histórico-cultural que se desenvolve no cotidiano. E a fronteira entre as referidas disciplinas seria ilusória. Um corpo conceitual de uma teoria se inspira e dialoga com diferentes campos da ciência. Além de compartilhar conceitos de diferentes disciplinas científicas, há dentro de uma mesma disciplina modos diversos de relações conceituais. Portanto, em uma mesma teoria pode haver sistemas conceituais organizados logicamente, seja com conceitos teóricos, que requerem relações semânticas, seja com conceitos operacionais, que estão ligados à experiência direta sensível. Portanto, pode-se pensar que a ciência não é algo puro em si, mas uma forma de hibridização de variados conceitos de naturezas diversas e de diferentes conhecimentos na constituição de uma teoria e entre diferentes disciplinas da ciência.

Para a presente análise, entende-se que o conceito de hibridização rompe com a concepção de pureza absoluta e com concepções unívocas. Por conseguinte, a hibridização compreende a articulação de conceitos de naturezas diversas Destarte, não há um único modo de hibridização. Na vida cotidiana, há uma variedade de atividades que envolvem modos diferenciados de operar o pensamento. O que diferencia uma atividade de outra é a relação estabelecida entre a necessidade, que move as ações da pessoa, o objetivo e o modo como a pessoa executa a própria atividade, ou seja, o modo como estrutura e opera o pensamento.

Um exemplo de hibridização é o conhecimento escolar. Trata-se de uma atividade que apresenta necessidades e situações que requerem um modo particular de operar o pensamento por conceito. A atividade escolar caracteriza-se por ser um modo de conhecer, que se constitui da relação entre afirmativas concebidas como verdades e o conhecimento advindo da experiência direta. Ou seja, o enfoque está em tornar o conhecimento passível de ensino, o que implica a aceitação tácita da validade plena do conhecimento científico, sem questionamentos. Quando muito, o estudante é capaz apenas de enunciar um conceito científico. 
Do ponto de vista empírico, a pesquisa realizada por Araújo (1992) sobre a apreensão de conceitos de Química por estudantes do ensino médio corrobora a ideia de que o conhecimento escolar é híbrido. Para realizar sua investigação, a pesquisadora elegeu os conceitos de substância, material, mistura e solução com vistas a identificar sistemas conceituais apresentados por 374 estudantes pesquisados. Para isso, identificou como os estudantes coordenavam, supraordenavam e subordinavam os conceitos, quando respondiam às perguntas a eles dirigidas. Assim procedendo, ela identificou 34 sistemas conceituais diferentes para os conceitos de substância e de material e 24 para os de mistura e solução, entre outras formulações dos estudantes que não cabe, aqui, discutir. A pesquisadora verificou, também, que a maior parte dos estudantes organizou os enunciados dos conceitos de substância e material com alguma sistematização, ainda que rudimentar, tratando-os, de variados modos, sob a forma de conceitos científicos. Entre as diversas possibilidades que aponta a pesquisadora para a compreensão de seus resultados, encontra-se a ideia de que, na atividade escolar, ocorre uma articulação da linguagem científica com a cotidiana, o que poderia explicar a grande variedade de sistemas conceituais identificados.

Ou seja, tal experimento permite afirmar que a escola ensina um modo de conhecimento, o escolar, que é distinto do científico em sua estrutura e função, ainda que possa se originar deste último. Os conceitos escolares seriam, na verdade, uma forma híbrida de conhecimento, resultante do encontro de outras duas maneiras de operar o pensamento por conceitos: uma é a percepção sensível, juntamente com a experiência direta; a outra é o conhecimento proveniente da ciência, do qual não se deve duvidar. Sendo assim, não seria procedente, pois, atribuir à atividade escolar o papel de atividade propiciadora do desenvolvimento do pensamento por conceitos científicos. Quando muito, se o for, ela tão somente exerceria uma função preparatória para a iniciação científica do estudante.

$\mathrm{Na}$ ciência Química, é possível, também, encontrar hibridização conceitual em alguns de seus sistemas, ou seja, conceitos teóricos, que se caracterizam por relações semânticas, e também conceitos operacionais, que têm relação com a percepção sensível e com a experiência direta. Os sistemas conceituais teóricos, na Química, são estruturados com conceitos que ressaltam a natureza do objeto de estudo. Já os sistemas de enfoque experimental relacionam 
conceitos estritamente operacionais, modo de apresentação e propriedade física do mesmo objeto de estudo. Ou seja, por sua definição:

Matéria: tudo aquilo que, no universo, ocupa lugar no espaço. Substância: porção de matéria que tem um e somente um tipo de constituinte (TOLENTINO, M. et al., 1986, p.1723). [...] Material: porção de matéria que tem mais de uma substância. Material Homogêneo: tipo de material cujo aspecto é uniforme de ponto a ponto. Material Heterogêneo: tipo de material cujo aspecto é multiforme de ponto a ponto (SILVA,R. et al.,1986, p. 2029).

Os conceitos de substância e material evidenciam uma relação de natureza semântica, enquanto que os conceitos de material homogêneo e heterogêneo, uma relação operacional. Ou seja, por meio da percepção dos sentidos, verifica-se o aspecto da matéria. Os conceitos científicos - teóricos e operacionais - apresentam inter-relações de generalidade, podem estar supraordenados, estruturados em ligações de coordenação e subordinação.

Outros exemplos de hibridização são encontrados na articulação conceitual entre as ciências: é o caso do conceito de átomo, que transita tanto na Física como na Química. Em cada uma das ciências esse conceito se relaciona com o arcabouço teórico de uma determinada forma. Na Química Orgânica, por exemplo, o átomo é considerado como constituinte de moléculas que, por sua vez, explicam propriedades de substâncias, tais como ponto de fusão, ponto de ebulição e reatividade. Já na Física, os objetos de estudo que envolvem o conceito de átomo são outros. Procura-se descrever, por exemplo, os movimentos dos elétrons, as forças que atuam nos núcleos atômicos, etc, com um enfoque maior às partículas subatômicas.

A Psicologia é mais um caso exemplar de hibridismo na ciência. Verificam-se, em sua população conceitual, conceitos teóricos - desenvolvimento, consciência - e operacionais - reforço, instrução. Além disso, há conceitos oriundos de diferentes ciências, como a medicina - diagnóstico - e a biologia - adaptação.

Pode-se afirmar, portanto, que não cabe adotar duas categorias conceituais - cotidianos e científicos -, como fez Vigotski em seus estudos. O teórico afirma que ambos os conceitos apresentam gênese, estrutura e função 
diferentes. Realmente, os conceitos apresentam estruturas e funções diferenciadas conforme a atividade em que se desenvolvem. Entretanto, a gênese é a mesma para qualquer conceito, ou seja, a cotidianidade.

$\mathrm{Na}$ vida cotidiana, há uma variedade de atividades, que requerem um modo particular de operar o pensamento por conceito, assim como há uma multiplicidade de conceitos que se desenvolvem. Logo, há uma infinidade de conhecimentos. Ou seja, os conceitos científicos desenvolvem-se na atividade científica; o conceito escolar, na atividade escolar. Assim, há tantos tipos de conceitos quantas atividades são desenvolvidas.

\section{Descompasso nos estudos de Vigotski}

Estudar a teoria de Vigotski significa despir-se de ideias preconcebidas, conhecer o momento histórico e debruçar-se em seus textos de modo a aceitar o convite para seguir seu pensamento e os caminhos que o levaram à teoria históricocultural. Nessa caminhada verificou-se certo descompasso em relação à sua concepção de escola e ciência em momentos diferentes de sua vida.

Em sua obra Psicologia Pedagógica (2003), publicada em 1926, Vigotski expressa seu pensamento libertário ao fazer severas críticas ao modo de organização escolar vigente ${ }^{19}$. Ele entende a educação e a ciência como empreendimentos humanos enraizados na vida. Assim ele diz:

Na própria natureza do processo educativo, em sua essência psicológica, está implícita a exigência de um contato e de uma interação com a vida que sejam o mais estrito possível. Em suma, só a vida educa e, quanto mais amplamente a vida penetrar na escola, tanto mais forte e dinâmico será o processo educativo.[...] Na cidade do futuro certamente não haverá nenhum edifício com a placa de "escola", porque a escola, que significa - no sentido exato da palavra - "ócio" e que destinava pessoas especiais e um prédio especial para as tarefas "ociosas", passará a pertencer por completo ao

\footnotetext{
${ }^{19}$ Vigotski, ao explanar a respeito da importância do conhecimento científico na transformação do processo pedagógico e do conceito de educação, cita Trotski em dois momentos na obra Psicologia Pedagógica (2004). No primeiro deles, afirma que "Não se trata apenas da educação, mas da 'refundição do homem', conforme expressão de Trotski" (p.301); o segundo momento é ao concluir seu livro (p. 304) com uma longa citação da obra de Trotski Literatura e Revolução, de 1923. Em outras edições, foram retiradas as aspas para evitar a menção a seu autor. Tais citações contribuíram para que essa obra fosse proibida na URSS.
} 
âmbito do trabalho e da vida, e estará na fábrica e na praça e no museu, e estará no hospital e no cemitério (VIGOTSKI,p.300, 301).

Ao mesmo tempo, em seu trabalho $O$ significado histórico da crise na Psicologia (VIGOTSKI, 2004; VYGOTSKI, 1997d), escrito em 1927, Vigotski defende uma ciência enraizada na vida cotidiana, sobre bases filosóficas que constituem o método. Concordando com Ivanovski $(1923)^{20}$, cita literalmente um trecho de obra desse autor:

A ciência tem uma estrutura variada e a compreensão desse fato tem um significado importantíssimo para a cultura científica do indivíduo. Cada tese científica particular possui seu grau de autenticidade próprio, inerente apenas a ela e dependente do procedimento e grau de sua fundamentação metodológica, e a ciência - enfocada metodologicamente - não constitui uma superfície homogênea contínua, mas um mosaico de teses de diferentes graus de autenticidade (IVANOVSKI, 1923, apud VIGOTSKI, 2004, p.264).

Para Vigotski, é um equívoco "a reunião de toda a heterogênea estrutura do sistema científico num plano, numa 'superfície homogênea contínua"' (VIGOTSKI, 2004, p.264).

Contudo, em sua obra Pensamento e Fala (2007) de 1934, o autor apresenta uma posição teórica dissonante. Nessa obra, conforme já foi dito anteriormente, o autor afirma que na escola, a criança tem oportunidade de acesso ao conhecimento científico que proporciona o desenvolvimento de sua consciência reflexiva. Assim, para ele, a origem do pensamento por conceito científico encontrase na atividade escolar (ou instrucional). Além, disso, admite que esse tipo de pensamento apoia-se no pensamento por conceitos cotidianos, cuja gênese encontra-se na atividade cotidiana. Logo, ele reconhece que há, no plano genético, funcional e estrutural, uma diferenciação dos dois tipos de conceito. Ao mesmo tempo, enfatiza que os dois tipos de pensamento interagem:

${ }^{20}$ Infelizmente, não foi possível acesso a esse trabalho. 
Por outro lado, temos de supor que o surgimento dos conceitos de tipo superior, como são os conceitos científicos, não pode deixar de estar sob a influência dos conceitos espontâneos, formados anteriormente, pela simples razão de que nem um nem outro conceito estão encapsulados na consciência da criança ou separados por uma barreira intransponível, tampouco correm por dois canais isolados, mas que se encontram em um processo de contínua interação que inevitavelmente conduz a que as generalizações mais elevadas por sua estrutura, próprias dos conceitos científicos, provoquem mudanças nas estruturas dos conceitos espontâneos (VIGOTSKI, 2004, p.286).

Ora, se os dois tipos de pensamento interagem, é forçoso admitir-se que o conhecimento científico que chega à criança e ao jovem, na escola, já tem, assim, um caráter híbrido, isto é, não é puramente científico, como ele quer fazer acreditar quando o distingue do cotidiano. Do mesmo modo e pelas mesmas razões, tampouco é puramente cotidiano o pensamento por conceito desenvolvido na cotidianidade. Vê-se, assim, que a distinção entre conceitos cotidianos e conceitos científicos, por ele admitida, é puramente formalista e parece ter um caráter meramente retórico, dada a contradição apontada.

Teria o autor mudado seu ponto de vista a respeito do papel da instrução escolar e, ao tentar valorizá-la, enredou-se nessa contradição, conforme já se apontou no início do presente trabalho? Não se tem informação disponível para saber o que o deixara insatisfeito com suas proposições a esse respeito quando, próximo a sua morte, declarou ver a necessidade de reformulá-las. Teria ele consciência dessa contradição? O que poderia ter acontecido?

Caruso (2007) teria razão, ao indicar que na obra Pensamiento y habla, de 1934, Vigotski tentara redimir-se perante o regime que se instalara na União Soviética? Por que Vigotski teria se preocupado em fazer isso? Apresenta-se no quadro a seguir a descrição de alguns acontecimentos, de alguma forma ligados a Vigotski, descritos na obra de Volkogonov (2004), publicada na Rússia em 1991.

O modo de pensar de Stalin era esquemático. Como vimos, ele gostava de ter tudo no devido "escaninho" e era levado a reduzir as idéias à sua forma mais simples e a popularizá-las quase ao ponto de pastiches primitivos. Se os oponentes divulgavam suas proposições de forma diferente, ele os ofendia pela "abordagem não-marxista", pela "demonstração de tendências pequeno-burgueses" ou pelo "escolasticismo anárquico". Seus relatórios e discursos eram sempre estruturados dentro de uma moldura rigorosa de enumerações, particularidades, características, níveis, direções, tarefas.

continua 
É provável que Stalin não tenha pensado, como Nero, que o estudo da filosofia "era um estorvo para o futuro governante", contudo, parece que ele foi intelectualmente incapaz de conseguir o menor domínio sobre o assunto. O ponto mais fraco de seu intelecto era a impossibilidade de entender a dialética. Ele tinha consciência disso, já que devotou muito tempo e esforço na tentativa de enriquecer seu conhecimento filosófico. Por recomendação dos diretores do Instituto dos professores Vermelhos, convidou, em 1925, Jan Sten, filósofo de renome entre os Velhos Bolcheviques, para ministrar-lhe aulas particulares sobre dialética. Sten, que era subdiretor do Instituto Marx-Engels e foi, mais tarde, executivo do aparato do comitê central, fora delegado em diversos congressos do partido, era membro da CCC, e homem de opinião independente. Nomeado tutor filósofo de Stalin, Sten planejou um programa especial que incluía o estudo de Hegel, Kant, Feuerbach, Fichte e Schelling, bem como de Plekhanov, Kautsky e Bradley. Duas vezes por semana, numa hora determinada, ia ao apartamento de Stalin e tentava elucidar seu pupilo nos conceitos hegelianos da substanciação, da alienação, da identidade entre realidade e razão. Tentava, em outras palavras, passar-lhe um entendimento do mundo real como manifestação de uma idéia. A abstração irritava Stalin, mas ele se controlava, sentava-se e ouvia a voz monótona de Sten, perdendo por vezes a paciência e o interrompendo com perguntas tais como "o que tudo isto tem a ver com a luta de classes?" ou "Quem emprega toda essa bobagem na prática?"

Lembrando a seu aluno que a filosofia de Hegel, como a de outros pensadores germânicos, se tornara uma das fontes do marxismo, Sten prosseguia imperturbável. "A filosofia de Hegel", afirmava ele, "é, com efeito, uma enciclopédia de idealismo. O método dialético é desenvolvido em seu sistema metafísico com alto grau de genialidade. Marx disse que Hegel pusera a dialética de cabeça para baixo, e que era hora de pô-la em pé, para que fosse vista racionalmente". Visivelmente agastado, Stalin interrompia: "Mas o que tudo isso tem a ver com a teoria do marxismo?"

Sten, pacientemente, tentava resumir e explicar a sutileza da filosofia de Hegel ao seu pupilo pouco perceptivo, porém, apesar de seus melhores esforços, Stalin não se mostrava capaz de captar as noções básicas daquela filosofia, como testemunharam seus próprios "trabalhos filosóficos". Parece que tudo o que restou daquelas lições foi a hostilidade ao professor. Juntamente com N. Karev, I.K.Luppol e com outros filósofos que eram discípulos do acadêmico A.M.Deborin, Sten foi declarado um teórico "adulador de Trosky" e, em 1937, acabou preso e executado. A mesma sorte parecia destinada a Deborin, que fora muito ligado a Bukharin no fim dos anos 20 e que, em 1930, foi rotulado por Stalin como "idealista militante menchevique". No entanto, ele foi poupado, se bem que proibido de desenvolver qualquer trabalho científico ou público.

Um encontro da Academia Comunista teve lugar em outubro de 1930 para debater "as diferenças no front filosófico". Na realidade, foi uma longa condenação de Deborin por sua "subestimação do estágio leninista no desenvolvimento da filosofia marxista". Deborin apresentou uma valente defesa, mas Milyutin, Mitin, melonov e Yaroslavsky "firmaram" sua culpa, juntamente com as de Sten, Kaven e Luppol, por subestimação da dialética materialista". As paixões no mundo acadêmico continuaram a fervilhar depois daquele encontro. Os acadêmicos não podiam aceitar o emprego de métodos policiais em seu trabalho. A filosofia foi, provavelmente, a primeira vítima da "pesquisa científica" stalinista. O Secretário-Geral deixou bem claro que só deveria haver um líder nas ciências sociais e que este era o papel do líder político, quer dizer, dele mesmo. Esta foi uma das razões pelas quais seus trabalhos eram populares, uma vez que acessíveis pela simplicidade, podiam ser captados pelo povo. Todavia, ao mesmo tempo em que tal modo de pensar talvez pudesse ter facilitado a popularização das ideias de Stalin, ele algemou severamente a capacidade criativa do povo, pois não demandava análise profunda ou entendimento da complexidade e interdependência do mundo. 
Dois meses mais tarde, em dezembro de 1930, ele falou sobre "o front filosófico" no birô do partido do Instituto de Professores de Professores vermelhos, cujo diretor era Abram Deborin. O discurso é exemplo eloquente de seu pensamento filosófico, do nível de sua racionalidade e, simplesmente, de sua falta de tato. De acordo com a ata da reunião, ele disse:

Temos que virar de pernas para o ar revolver o monte de estrume que se acumulou na filosofia e nas ciências sociais. Tudo o que foi escrito pelo grupo de Deborin precisa ser destruído. Sten e Karev podem ir às favas. Sten jacta-se bastante, mas é apenas um pupilo de Karev. Sten é um rematado preguiçoso. Só o que sabe fazer é falar. Karev tem uma cabeça enorme e pavoneia-se por aí como uma bexiga inflada. Na minha opinião, Deborin é caso perdido, mas deve permanecer como editor do periódico* para que tenhamos alguém para derrotar. O conselho editorial ficará com dois fronts, mas teremos a maioria.

As perguntas começaram a chover tão logo parou de falar: “ pode-se comparar a batalha sobre a teoria com o desvio político?"

Stalin respondeu: "Não só pode, deve, sem dúvida."

"E que dizer dos 'esquerdistas'? Você lidou com os 'direitistas'."

*Pod znamenem marksiazma ("Sob a bandeira do marxismo").

"O formalismo vem surgindo sob a camuflagem esquerdista," replicou Stalin.

"Anda servindo seus pratos com tempero esquerdista. Os jovens têm um fraco pelo esquerdismo. E estes senhores são bons cozinheiros."

"Em que o instituto deve se concentrar na área da filosofia?"

"Em derrotar, esta é a questão principal”, replicou Stalin. "Derrotar em todos os lados, e onde não tenha havido derrota antes. Os deborinitas encaram Hegel como um ícone. Plekhanov tem que ser desmascarado. Ele sempre olhou com certo desdém para Lênin. Até Engels não está correto em tudo. Existe um lugar neste comentário sobre o Programa Erfurt a respeito do crescimento dentro do socialismo. Bukharin tentou utilizá-lo. Não seria mau se pudéssemos implicar Engels em algum lugar dos escritos de Bukharin."

Dessa forma, Stalin, que não sabia praticamente nada de filosofia, "instruía” os filósofos. A questão principal era “derrotar”. Quanto à filosofia marxista, explicou o que deveria constar numa seção especial do Curso resumido: uma série de frases curtas incisivas dividindo a filosofia em Diversas características básicas, como muitos soldados cobertos e alinhados. Talvez esse "ABC filosófico", mais algumas outras fontes,ajudassem na campanha contra o desconhecimento, mas depois que os trabalhos de Stalin, a filosofia murchou, pois ninguém mais teve coragem de escrever coisa alguma sobre o assunto. Não se passara um mês e o comitê central já aprovava uma resolução sobre o periódico Pod zanamenem marksizma. Os adeptos de Deborin, que estavam congregados em torno do editor do periódico, foram alcunhados "grupo de mencheviques idealistas." (VOLKOGONOV, 2004, p.229-232).

Conforme Prestes (2010), a proximidade de Vigotski ao grupo de Deborin foi filosófica. O referido grupo estava envolvido no trabalho de elaboração do método dialético de estudo da natureza e da sociedade, pensamento, este, contrário à lógica formal. Deborin e seu grupo foram acusados de idealistas, antimarxistas e antileninistas. 
Assim, vê-se que a perseguição ao grupo de Deborin iniciou-se em 1925 e perdurou pelo menos até 1937, com a execução de Jan Sten. É possível que, se não tivesse falecido em 1934 de tuberculose, Vigotski teria tido a mesma sorte de Sten, pois a perseguição a ele continuou após a sua morte.

O texto Sobre as deturpações pedológicas de Vigotski, de autoria de E. I. Rudniova (2012), foi publicado com a tiragem de 10.000 exemplares, um ano e meio depois da Resolução do Comitê Central do Partido Comunista Russo (dos bolcheviques), de 4 de julho de $1936^{21}$. Trata-se de um livro de que se pode afirmar ter sido encomendado, o que era comum no regime stalinista, dado o seu teor ideológico e doutrinário, repleto de acusações sem uma devida argumentação, com ideias desconexas e incoerências. A autora procura mostrar, por meio de um exame superficial dos estudos de Vigotski a respeito da pedologia, do desenvolvimento psíquico, da consciência, da formação e desenvolvimento dos conceitos, da visão de educação e da crítica que ele faz à escola, o viés idealista e antileninista presente em seus trabalhos.

Uma das críticas apresentadas pela autora diz respeito à divisão dos conceitos feita por Vigotski em cotidianos e científicos. Ela afirma que o autor demonstra uma visão formalista, idealista e antileninista, mas não apresenta as razões que a levam a essa afirmação. Seja ou não antileninista - fato que não cabe, aqui, discutir, pois, naquela época, antileninista era o que Stalin julgava sê-lo (Volkogonov, 2004) -, o fato é que essa posição de Vigotski parece mais coadunarse com o pensamento marxista do que negá-lo. Heller (1994, 2004), indiscutivelmente uma pensadora de inspiração marxista contemporânea, faz a mesma distinção. Sorte a dela não ter vivido na União Soviética daqueles tempos.

Que ele procurava afirmar publicamente suas bases marxistas fica demonstrado na pesquisa realizada, na década de 1930, nas regiões remotas do Uzbequistão e Kirghizia, nas "kishlaks" (vilarejos) e "dzahailaus" (terras de pastoreio nas montanhas) por ele e seus colaboradores e relatada por Lúria (1990). Nela, fica notória a supervalorização do conhecimento científico sobre outras formas de conhecimento, desconsiderando outros modos de organização do pensamento e a

\footnotetext{
${ }^{21}$ Para conhecimento da referida Resolução sugere-se a leitura do texto traduzido na íntegra na seguinte obra: PRESTES, Z. Quando não é quase a mesma coisa: traduções de Lev Semionovitch Vigotski no Brasil. Campinas: Autores Associados, 2012.
} 
diversidade cultural. A pesquisa tinha como proposta de investigação a análise das "mudanças na estrutura dos processos mentais subjacentes à atividade mental ao longo dos diferentes estágios do desenvolvimento e desvendar as mudanças até agora desconhecidas nas 'relações interfuncionais' entre os processos" (p.26), em camponeses. A hipótese consistia no fato de que "pessoas cujo processo de reflexão da realidade fosse primariamente gráfico funcional mostrariam um sistema de processos mentais distinto daquele encontrado em pessoas cuja abordagem da realidade fosse predominantemente abstrata, verbal e lógica" (p.33). Cabe ressaltar que a população pesquisada não tivera acesso ao conhecimento escolar, ao passo que todo material da pesquisa fora pensado sob o olhar do escolarizado. O modo de vida daquele povo $e$ as atividades que realizavam cotidianamente não foram examinados; não se considerava, portanto, a cultura e o contexto histórico daquele povo. Sob o olhar da ciência, os resultados demonstraram a importância do conhecimento científico e do processo de escolarização.

Não há como afirmar com certeza as razões que conduziram Vigotski a esse descompasso entre suas ideias. Mas pode-se ter em mente o fato de que, por necessidade de sobreviver e de proteger sua família, tenha procurado atenuar algumas de suas ideias que contrariariam o Regime. Sabe-se que, naquela época, esposa e descendentes de pessoas condenadas pelo regime eram também perseguidos e, muitas vezes, até executados (o medo de isso acontecer era intenso, profundo, justificado e difundido - veja-se fac-simile de uma reportagem recente no Anexo A).

Ao que tudo indica, o fato de ter explicitado, por meio de suas publicações, suas bases marxistas não foi o suficiente, pois, mesmo após a sua morte, continuou sendo criticado, censurado e depreciado em meios acadêmicos. Pelo menos ficaram vivos descendentes seus, que, hoje, ajudam a desvendar tão intrincada história. 


\section{A ATIVIDADE ARTESANAL E O PENSAMENTO CONCEITUAL}

Neste capítulo, são examinadas duas atividades artesanais, buscando-se verificar os modos de pensamento conceitual dos artesãos. Em um primeiro momento, é tratado o conceito de atividade, segundo a perspectiva de Vigotski, e suas implicações para o desenvolvimento do pensamento. Num segundo momento, são descritas duas atividades: a de ourivesaria, que existe há mais de cinco mil anos, aproximadamente, para a confecção de objetos utilitários, armas e ornamentos; e a do sineiro, que existe desde o século IV d.C., aproximadamente, para o fabrico artesanal de sinos, em sua forma convencional. A descrição feita tem por base, essencialmente, os relatos dos artesãos, dos quais também foram extraídas as informações para se configurar suas constelações conceituais.

\section{Atividade}

Em suas investigações a respeito do desenvolvimento humano, Vigotski centrou suas atenções na variedade de modos de desenvolvimento das funções psíquicas superiores pelo uso funcional da palavra no enfrentamento das tensões presentes na vida. Segundo ele, o processo de desenvolvimento psíquico acontece em atividades histórica e culturalmente formadas.

Ainda que Vigotski não tenha elaborado, estritamente falando, uma teoria da atividade, conforme salienta Prestes (2010), dedicou-se, aqui e ali, ao exame teórico de alguns fatos importantes a esse respeito. Por exemplo, é bastante conhecido o exame teórico que empreendeu da atividade de brincar de faz de conta e de seu papel no desenvolvimento psicológico da criança. Dedicou-se, também, bastante à investigação da atividade de instrução e sua importância para o desenvolvimento psíquico.

Não foi um mero capricho a escolha dessas duas atividades por ele. Segundo o seu pensamento, em cada fase de vida, fase esta culturalmente definida 
e demarcada, há um tipo especial de atividade que guia o desenvolvimento psíquico do indivíduo. Assim, por volta dos 3 ou 4 anos de idade, a atividade-guia é a brincadeira de faz de conta; na idade escolar é a instrução, assim como na adolescência é o convívio em grupos sociais. Seguindo a lógica do seu raciocínio, pode-se dizer que, na vida adulta, a atividade-guia é o trabalho. Não se pode, contudo, perder de vista que, diferentemente da atividade-guia brincadeira de faz de conta, a atividade-guia trabalho aparece numa diversidade estrutural infinitamente maior que aquela. A atividade-guia "carrega fatores valiosos e que contêm elementos estruturais que impulsionam o desenvolvimento, ou seja, guia o desenvolvimento psíquico" (PRESTES, 2010, p.163). Ela propicia a formação e a reestruturação dos processos psicológicos.

$O$ ato de arrostar as tensões presentes na atividade possibilitaria, segundo Vigotski, o desenvolvimento das funções psíquicas, que se relacionam em um sistema de conversões e movimentos interfuncionais, na unidade afeto-intelecto. Com o emprego funcional da palavra, na intrincada relação pensamento e ação, são dadas as possibilidades de domínio dos processos psíquicos pelo enfrentamento de conflitos e crises que constituem o próprio viver.

Conforme já comentado neste trabalho, a unidade dialética afeto-intelecto está na base de cada atividade, seja ela prática ou intelectual, e funda um sistema semântico-dinâmico, nas relações entre o pensamento e a ação. No processo de desenvolvimento das funções psicológicas superiores, o essencial é a unidade do sistema dinâmico-semântico, como afirma Vygotski (1997b):

[...] os processos afetivos e intelectuais representam uma unidade, mas esta não é uma unidade imóvel e constante. [...] o mais essencial para todo o desenvolvimento psicológico [...] é precisamente a mudança das relações entre afeto e intelecto. [...] no curso do desenvolvimento, se modificam não tanto as propriedades e a estrutura do intelecto e do afeto, mas as relações entre os mesmos. Mais ainda, [...] estão em dependência direta com a mudança de seus nexos e relações interfuncionais, com o lugar que estes ocupam na consciência, nas diferentes etapas do desenvolvimento (VYGOTSKI, 1997, p.271, 272). 
Na atividade, a dinâmica do pensamento está ligada à da ação; ambas se modificam na situação real. Esse movimento acontece na vida vivida, determinando a consciência, que surge da vida. Como Vygotski (1997b, p.269, 271, 272) diz:

[...] o próprio pensamento determina a vida ou, mais exatamente, a vida pensante se determina a si mesma através da consciência. [...] no curso do desenvolvimento, se modificam não tanto as propriedades e estrutura do intelecto e do afeto, quanto as relações entre os mesmos. Mais ainda, as mudanças do afeto e do intelecto estão em dependência direta da mudança dos nexos e relações interfuncionais, do lugar que estes ocupam na consciência nas diferentes etapas do desenvolvimento.

Enfim, o desenvolvimento das funções psíquicas superiores está atrelado à unidade dos sistemas dinâmico-semânticos, posto que ter consciência de algo significa ter controle sobre o pensar. Uma função consciente adquire também distintas possibilidades de ação.

$\mathrm{Na}$ vida do homem há diferentes atividades, que requerem modos diversos de operar o pensamento por conceito. Contudo, o que irá caracterizá-las é a relação estabelecida entre a necessidade, que move as ações da pessoa, o objetivo e o modo como ela executa a atividade, ou seja, o modo como estrutura e opera o pensamento. Diante de uma dificuldade, afirma Vygotski (1997b), surge a reação do intelecto, em que a necessidade do pensamento prevalece sobre as reações instintivas e automáticas de conduta, com vistas a adaptar-se às condições das novas circunstâncias.

$\mathrm{Na}$ base da atividade, há uma unidade de funções dinâmicas, o pensamento e a ação real, que apresentam propriedades diferentes e estão em constante movimento. Entretanto, não constituem duas dinâmicas, pois como afirma Vigotski (1997b, p.266), "na realidade a dinâmica não existe à margem da função que põe em movimento". A atividade do pensamento, fluida, e a da ação, menos móvel, não constituem dois campos isolados, mas estão inter-relacionadas, de modo que há a transformação do pensamento em ação e da ação em pensamento.

Assim como nossas ações não nascem sem causa, senão que são movidas por determinados processos dinâmicos, necessidade e estímulos afetivos, 
também nosso pensamento sempre é motivado, sempre está psicologicamente condicionado, sempre deriva de algum estímulo afetivo pelo qual é posto em movimento e orientado. O pensamento não motivado dinamicamente é tão impossível como uma ação sem causa. Nesse sentido, já Spinoza definia o afeto como algo que aumenta ou diminui a capacidade de nosso corpo para a ação e obriga o pensamento a mover-se em uma direção determinada (VYGOTSKI,1997b, p.266).

Entende-se, assim, que há uma unidade entre o pensamento e a ação, ou seja, não há uma ação que não tenha sido pensada e um pensamento que não venha refratar a ação. Vygotski (1997b) esclarece que a ação refratada pelo pensamento se transforma em uma ação plena de sentido, portanto, consciente e voluntária.

Na resolução de problemas que surgem na atividade, diante do desafio de buscar soluções ou modos diferenciados para se chegar ao objetivo, seja pela própria experiência ou a de outros, juntamente com as necessidades que se expressam no desenrolar da ação, está presente a imaginação. No processo de desenvolvimento do pensamento, essa função psíquica encontra-se desde a mais tenra generalização até a formulação conceitual e, também, em diferentes campos da vida cultural, materializando-se na criação artística, científica e técnica. Atrelada à imaginação está o criar. Como ressalta Vigotski (2009), a vivência possibilita a criação, pois amplia a quantidade de elementos da realidade de que a pessoa pode dispor.

A nossa ideia cotidiana de criação não corresponde plenamente à compreensão científica dessa palavra. [...] é corriqueiro pensarmos que na vida de uma pessoa comum não haja criação. No entanto, como já foi dito, esse ponto de vista é incorreto. [...] Da mesma forma, a criação, na verdade, não existe apenas quando se criam grandes obras históricas, mas por toda parte em que o homem imagina, combina, modifica e cria algo novo, mesmo que esse novo se pareça a um grãozinho, se comparado às criações dos gênios. [...] $\mathrm{Na}$ vida cotidiana que nos cerca, a criação é condição necessária da existência, e tudo que ultrapassa os limites da rotina, mesmo que contenha um iota do novo, deve sua origem ao processo de criação do homem. [...] Quanto mais rica a experiência da pessoa, mais material está disponível para imaginação dela. [...] A imaginação origina-se exatamente desse acúmulo de experiência (VIGOTSKI, 2009, P.15,16, 22). 
O relato da experiência do outro possibilita a ampliação da experiência da pessoa, pois, por meio da descrição de outrem, a pessoa pode imaginar o que não vivenciou diretamente. A imaginação possibilita experienciar o não vivido e contribui para a atividade mental humana (VIGOTSKI, 2009). É na vivência de diversas atividades que a pessoa cria as condições de estruturação do próprio comportamento e estabelece relações com o mundo por meio da apropriação das ferramentas histórico-culturais.

Portanto, pode acontecer de a mesma atividade se realizar de modos diferenciados. Não há um padrão de atividade, pois ela está relacionada às necessidades e ao sistema dinâmico-semântico, próprio de cada pessoa. Para afirmar que uma atividade propicia ou não o desenvolvimento é necessário o estudo do papel que ela exerce na vida da pessoa que a realiza. Uma mesma atividade pode se estruturar com modos diferentes de operar o pensamento, seja com conceitos operacionais ou com conceitos teóricos, ou ainda, com ambos os conceitos relacionados, caracterizando uma forma híbrida, muito presente na atividade escolar, na atividade do cientista, assim como na atividade do ourives e na do sineiro.

\section{A Ourivesaria}

\section{Um olhar para a história}

Artefatos arqueológicos indicam que no período neolítico já havia o fabrico de armas, de utensílios e adornos com materiais mais resistentes como o cobre e o ouro. A idade dos metais caracteriza-se pela fabricação de ferramentas e armas de metal (GOLA, 2008). Com o domínio da técnica de fundição, mesmo que rudimentar, foi possível criar instrumentos para o cultivo agrícola, para a caça e para o fabrico de armas. Inicialmente, as matérias primas foram o cobre e o estanho; posteriormente, o bronze (liga de cobre com estanho). As Figuras 3 a 8, mostradas a seguir, ilustram alguns utensílios e ferramentas. 


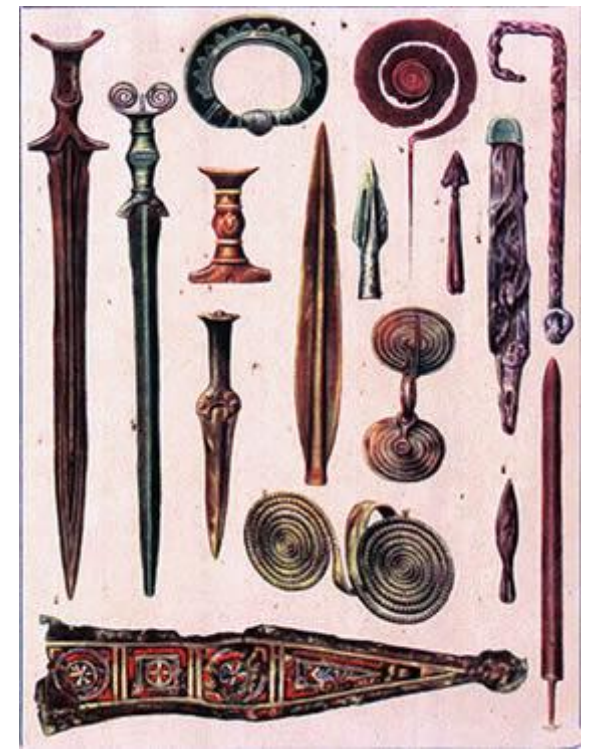

Figuras 3. Armas e ferramentas criadas durante a ldade dos Metais.

Fonte: Disponível em:< http://www.historiadetudo.com/idade-metais.html >. Acesso em 07 abr. 2013.

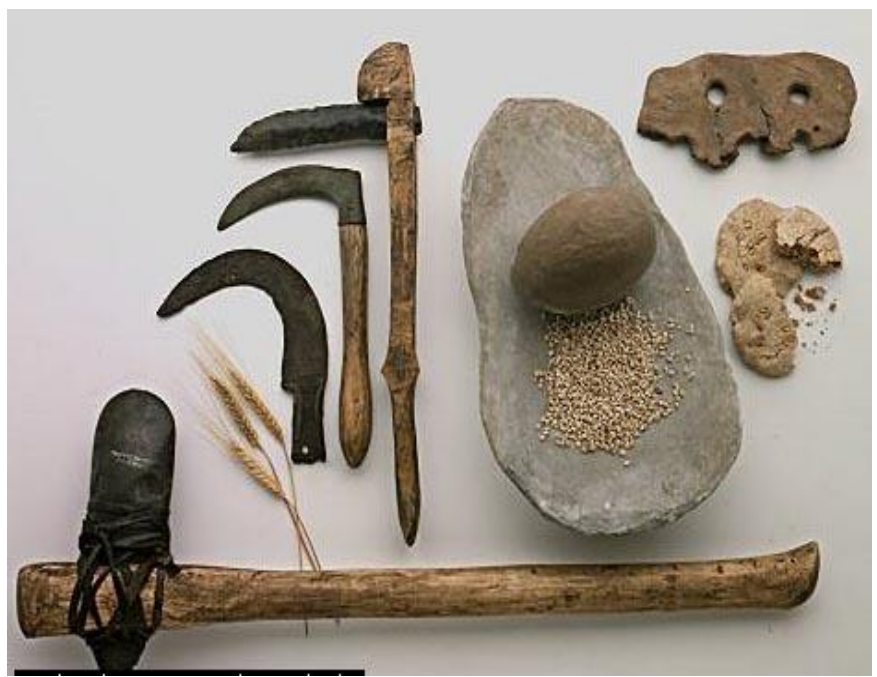

Figura 4. Armas e ferramentas criadas durante a Idade dos Metais.

Fonte: Disponível em:< http://www.historiadetudo.com/idade-metais.html >. Acesso em 07 abr. 2013. 

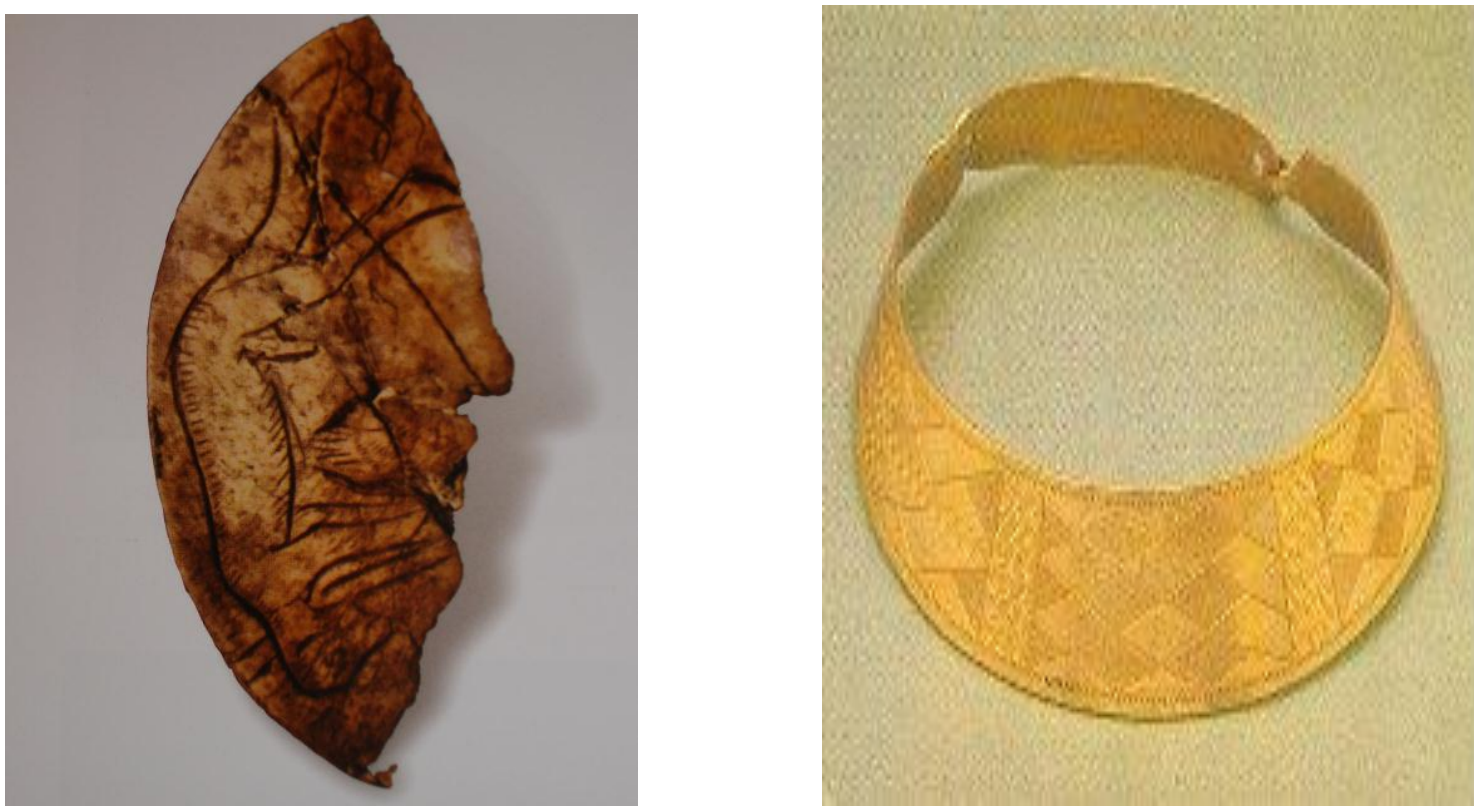

Figura 5. Adorno pré-histórico. Perfil humano com tema animal. Figura 6. Ornamento em ouro - Idade dos metais Fonte:Disponível em:http://www.historiadetudo.com/idade-metais.html. Acesso em 07 abr.2013.

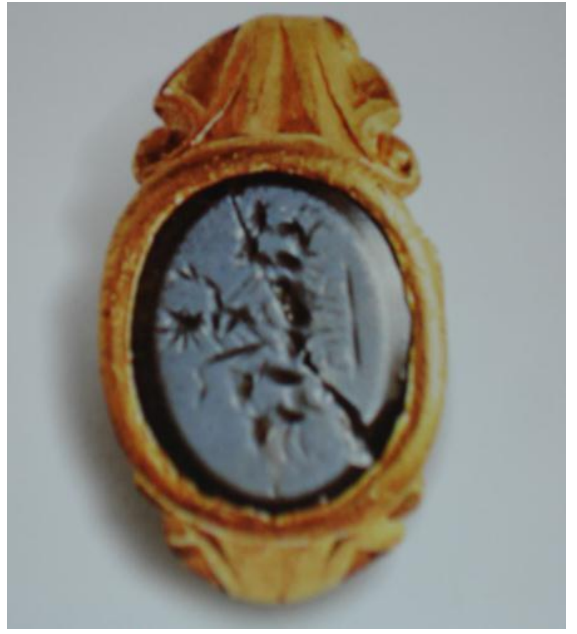

Figura 7. Parte superior de anel em ouro com selo incrustado. Fonte: GOLA (2008)

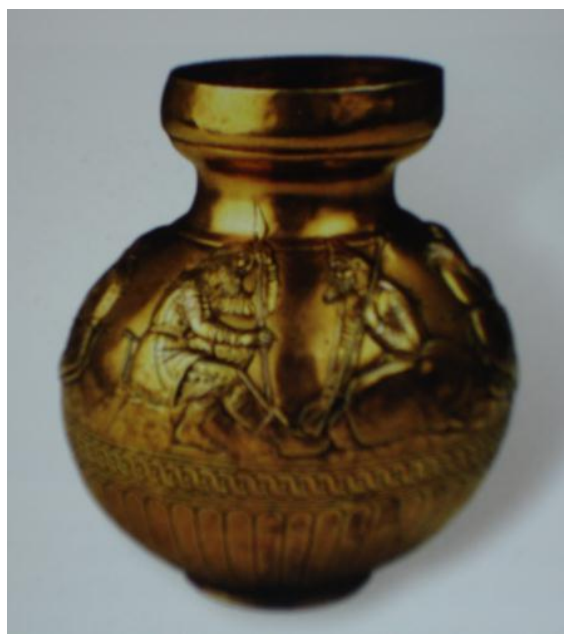

Figura 8. Vaso cita de ouro (séc.IV a.C.). Fonte: GOLA (2008)

Em várias civilizações, como a mesopotâmica, egípcia, etrusca, persa, cita, grega e romana, o ouro era associado ao Sol e valorizado por sua cor e brilho e pelo fato de não se oxidar (ver Figuras 9 a 12). Por sua maleabilidade e suavidade, foi muito utilizado na criação de ornamentos com e sem pedras preciosas associadas (GOLA, 2008). 


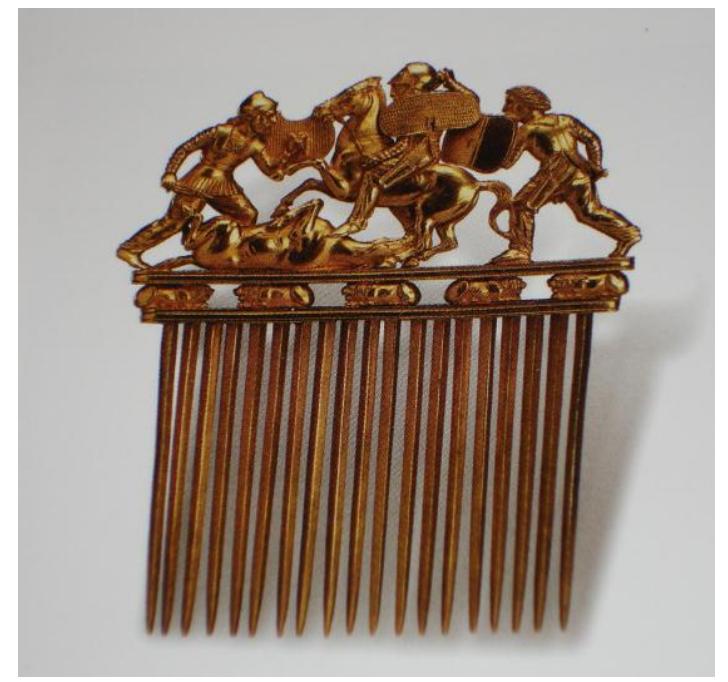

Figura 9. Pente cita (século IV a. C.). Fonte: GOLA (2008)

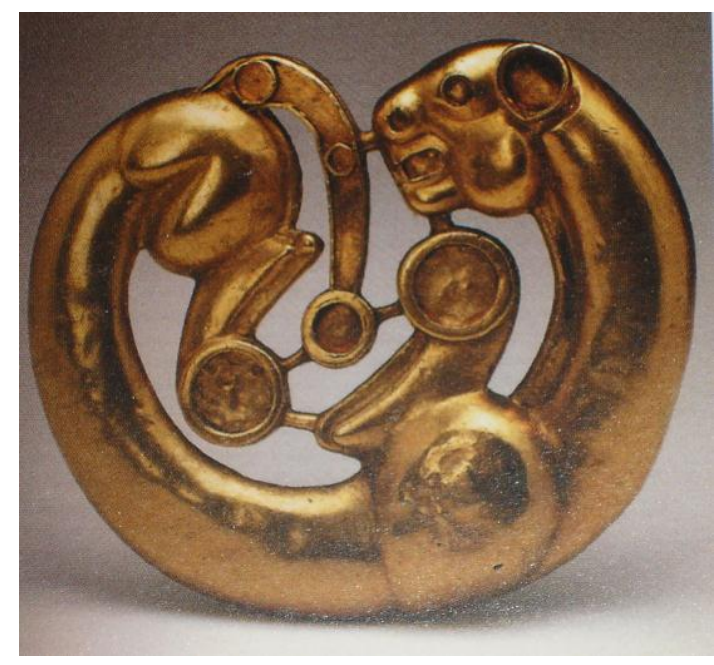

Figura10. Pantera que adornava escudo(cita-siberiano). Fonte: GOLA (2008)

Por volta de 2.000 a.C., os ourives desenvolveram as habilidades e técnicas para modelar o ouro, como a técnica de granulação, que consistia em formar um desenho com minúsculas esferas de metal. Essa técnica expandiu-se pelo oriente (GOLA, 2008).

No antigo Egito, o ouro era utilizado na fabricação de mobiliários, utensílios e armas, sendo que, por volta de 1200 a.C., aparecem taças e punhais com incrustações em ouro (METAMIG, 1981). 
diademas, colares, anéis, braceletes [...]. na Grécia Antiga, o estilo de suas peças deriva dos fenícios (METAMIG, 1981,p.164).

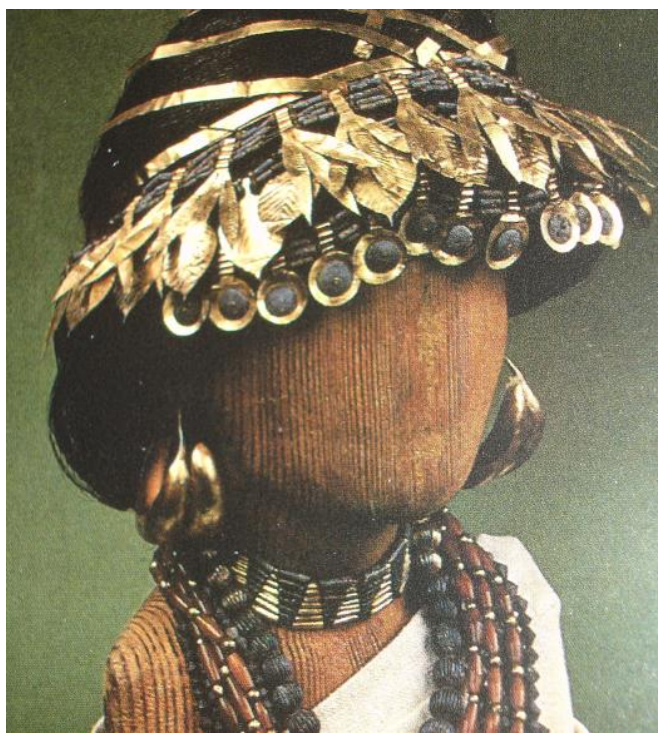

Figura 11. Joias de dama da corte Shub-ab (Ur, 2800a.C.) Fonte: GOLA (2008)

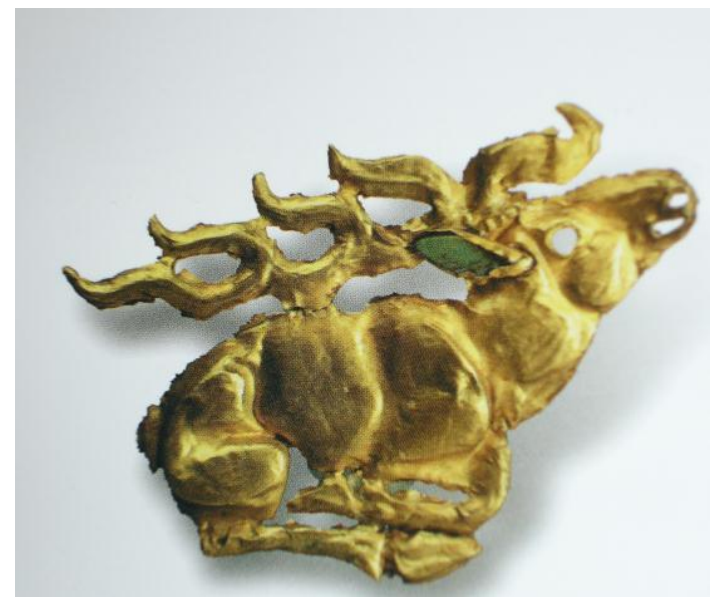

Figura 12. Arte zoomórfica cita (séculos VII e VI a. C.). Fonte: GOLA (2008)

A combinação de pedra de cor com ouro tornou-se popular no Egito e na Mesopotâmia. [...] O estilo fenício punha em evidência a granulação somada a outras técnicas decorativas, e espalhou-se pelo Mediterrâneo, do que hoje é a Síria até a Espanha. A soberba joalheria dos etruscos, mais conhecida pelo trabalho minucioso e perfeito da granulação, deve muito aos fenícios, que difundiram e agregaram outras influências com as quais entraram em 
contato em suas viagens. Entre essas influências, devemos mencionar os motivos de animais das estepes russas (para onde migraram os Citas), da Turquia e da Pérsia, os ornamentos, como pulseiras com motivos florais, ou, ainda, o estilo céltico para o qual o Art Nouveau olharia como fonte de inspiração mais de 2 mil anos depois (GOLA, 2008, p.32 e 33).

A ourivesaria envolve a fabricação de objetos utilitários e de armas, a criação de peças ornamentais e a confecção de joias propriamente ditas, utilizando o cobre, o bronze, o ouro e a prata, associados a pedras preciosas, conforme a cultura e a época. Contudo, a joalheria surgiu com a ourivesaria no decorrer da história, pelo próprio manuseio de metais preciosos e de pedras, restringindo-se à criação de joias. No decorrer dos séculos, as peças ornamentais e joias foram cada vez mais elaboradas, aperfeiçoando-se técnicas de filigrana, de cravações de pedras coloridas, especialmente lápis-lazúli, turquesa, cornalina, esmeraldas, safiras e pérolas. São anéis, brincos, tiaras, colares, broches, diademas, braceletes, vasos e jarras (GOLA, 2008), conforme mostram as Figuras 13 a 16.

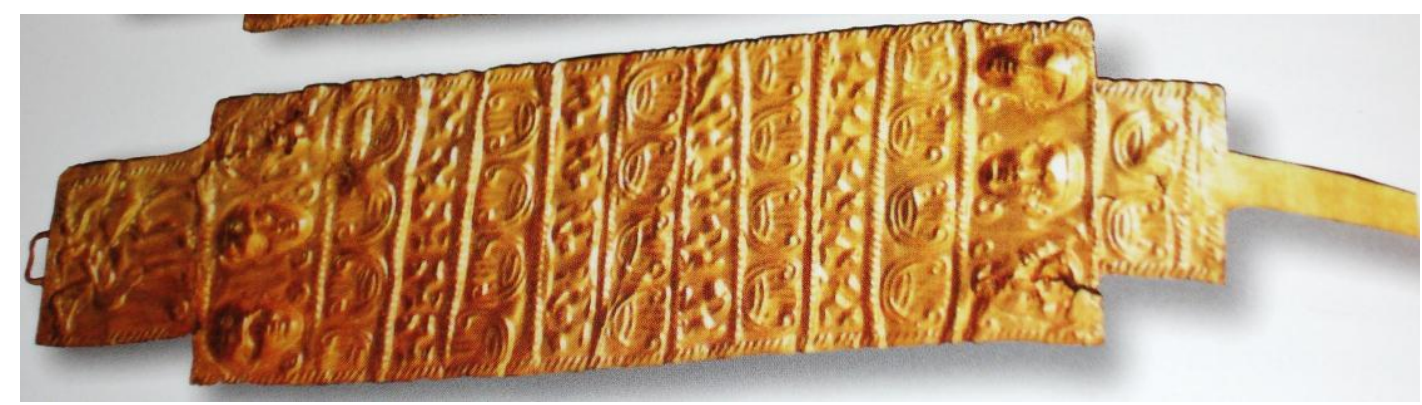

Figura 13. Braceletes etruscos - século VII a.C..

Fonte: GOLA (2008) 


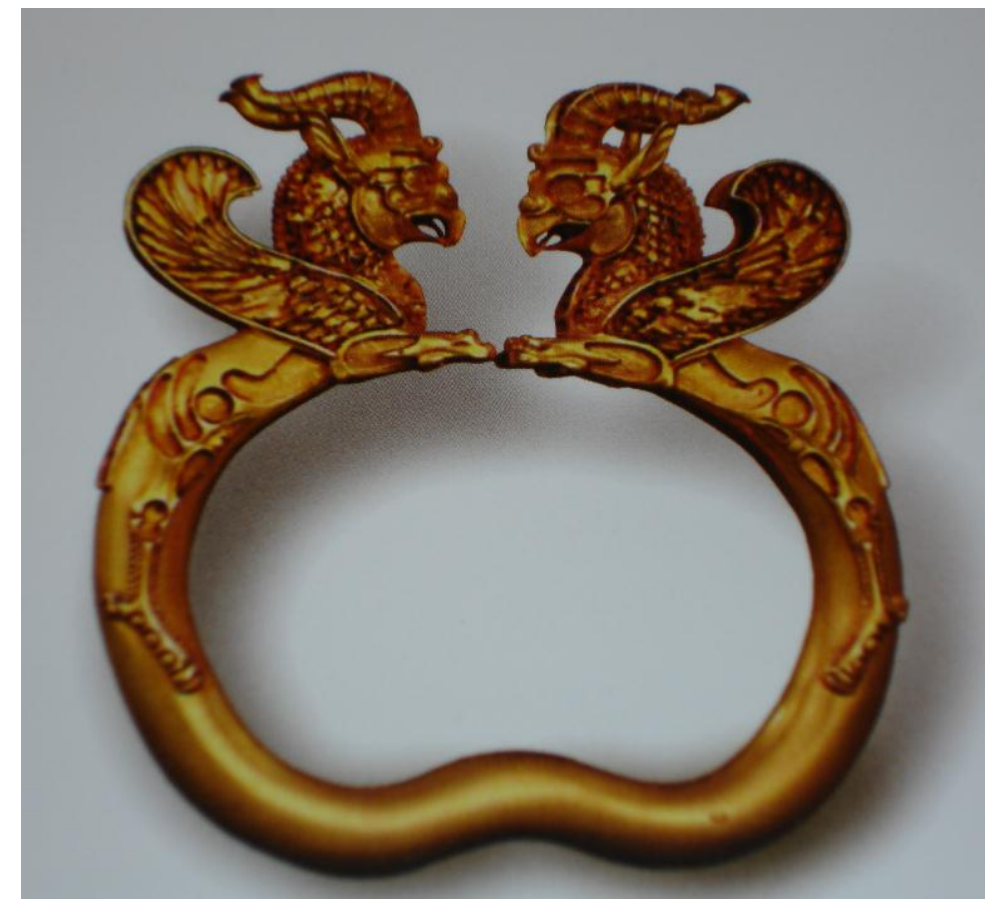

Figura14. Bracelete persa (séc. V e IV a.C.). Fonte: GOLA (2008)

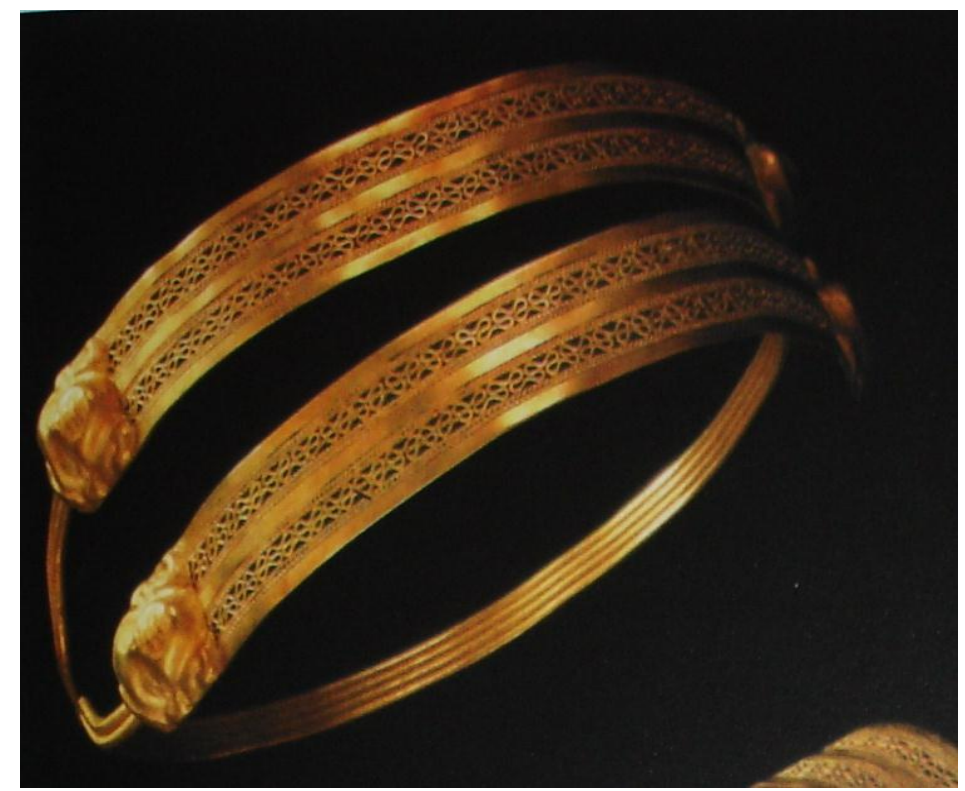

Figura15. Diademas etruscos em ouro e filigrana. Fonte: GOLA (2008) 


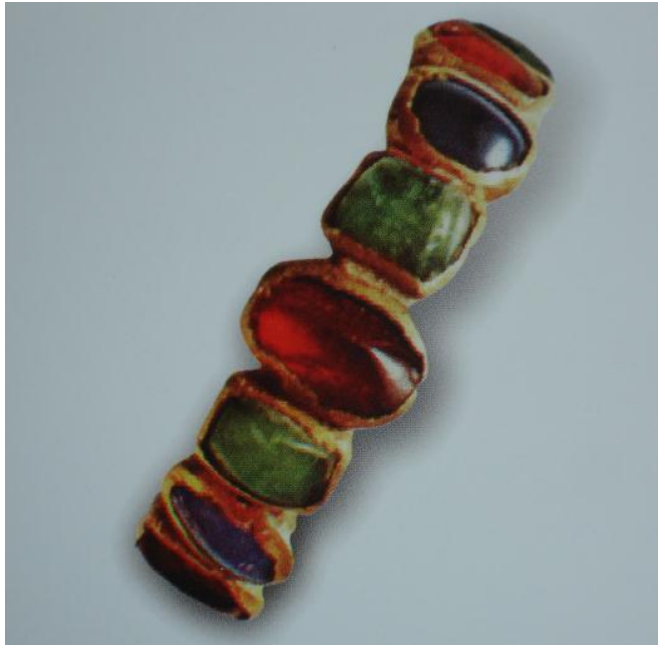

Figura16. Anel com cravação inglesa - granada, safira e esmeralda (séc. III a.C.). Fonte: GOLA (2008)

Entre os séculos VII e XII, grande parte da produção de objetos pela ourivesaria destinou-se a ornamentar e enriquecer igrejas e catedrais por toda a Europa. Os objetos eram de culto religioso, cálices, relicários e mobiliário. Os temas mais explorados eram florais, estampas de animais e rostos. Uma característica dos objetos fabricados é que eles eram mais decorativos do que utilitários (METAMIG, 1981), conforme se observa nas Figuras 17 e 18.

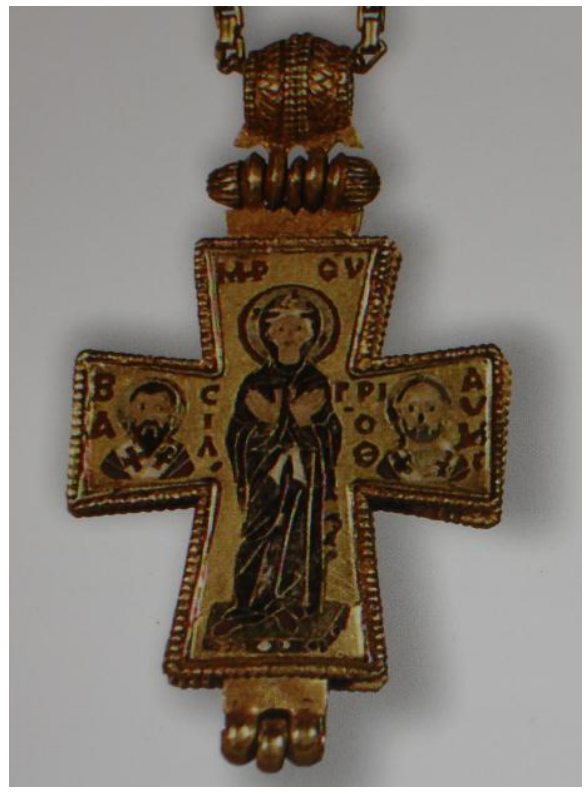

Figura 17. Relicário bizantino (séc $X)$. Fonte: GOLA (2008) 


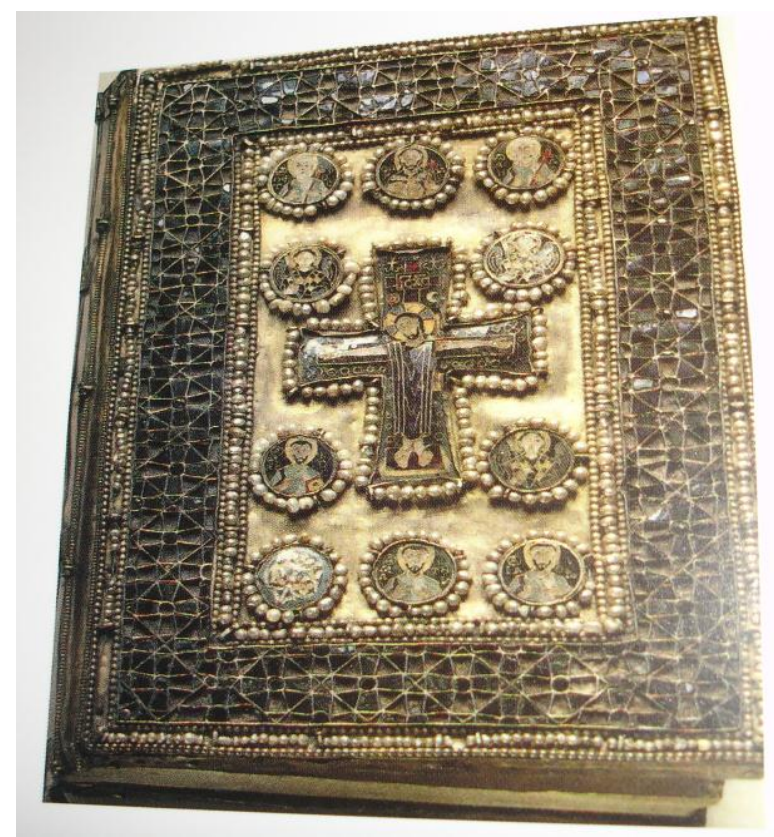

Figura18. Encadernação esmaltada com pérolas (séc. IX). Fonte: GOLA (2008)

O trabalho da ourivesaria europeia, afirma Gola (2008), sofreu grande influência oriental. Foi esculpindo e polindo que se desenvolveu a técnica da lapidação. Inicialmente as pedras opacas recebiam polimento em forma de cabochão. A técnica da lapidação passa por transformações no decorrer dos séculos, substituindo-se o método de gemas esculpidas pela técnica em facetas nas pedras (ver Figura 19).

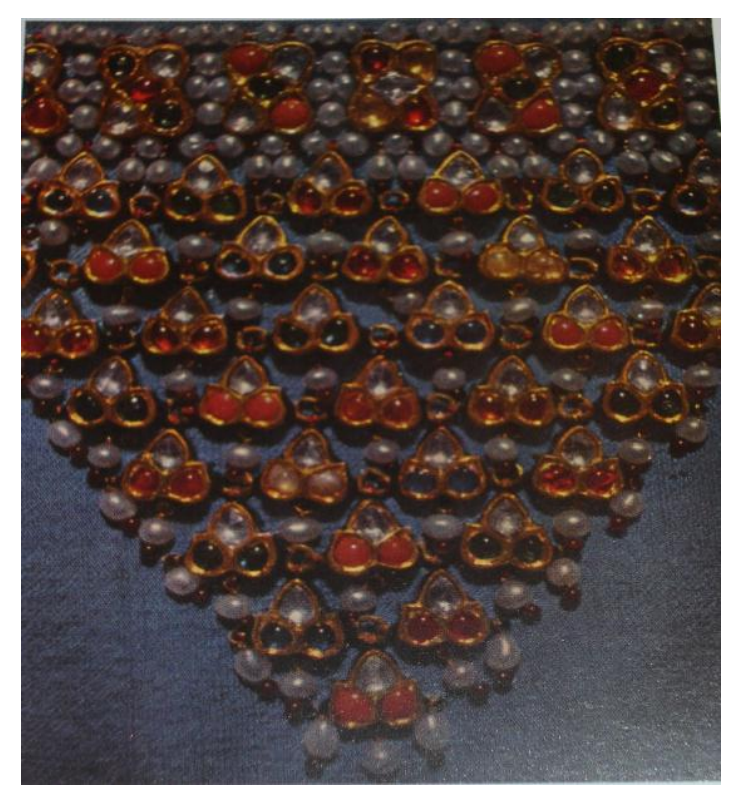

Figura 19. Colar indiano estilo mongol com pedras naturais, translúcidas e polidas em forma de cabochão (séc.XIV). Fonte: GOLA (2008) 
Dos séculos XI ao XIII o ouro foi cunhado no mundo mulçumano e talvez tenha sido em decorrência da ocupação árabe que a Espanha medieval produziu também algum ouro. É interessante observar que o ouro europeu fluía para o oriente, na Idade Média, pela via comercial, em troca de produtos como seda e especiarias. Esse metal voltou à Europa com os mulçumanos, como instrumento do comércio geral. A partir do século XI o ouro mulçumano circulava na Espanha, cujos reinados independentes refundiam as moedas auríferas árabes transformando-as em "moedas cristãs". Posteriormente, no século XIII, Florença, Gênova e Veneza passaram a cunhar moedas de ouro. Enfim, no século XIV, França e Inglaterra também conseguiram cunhar o ouro e 0 uso de moedas de ouro se popularizou no mundo ocidental (METAMIG, 1981,p.15 e 16).

Na Idade Média, as pedras preferidas na Europa eram a safira, o rubi, a esmeralda e o diamante. Na Renascença, os motivos das peças eram religiosos e elas eram cravadas com diamantes (GOLA, 2008). O século XVI apresentou uma inovação na técnica-estética das joias: o talhe das pedras e novos temas das criações - a botânica, a floricultura, as divindades e os heróis -, conforme mostram as Figura 20 e 21.

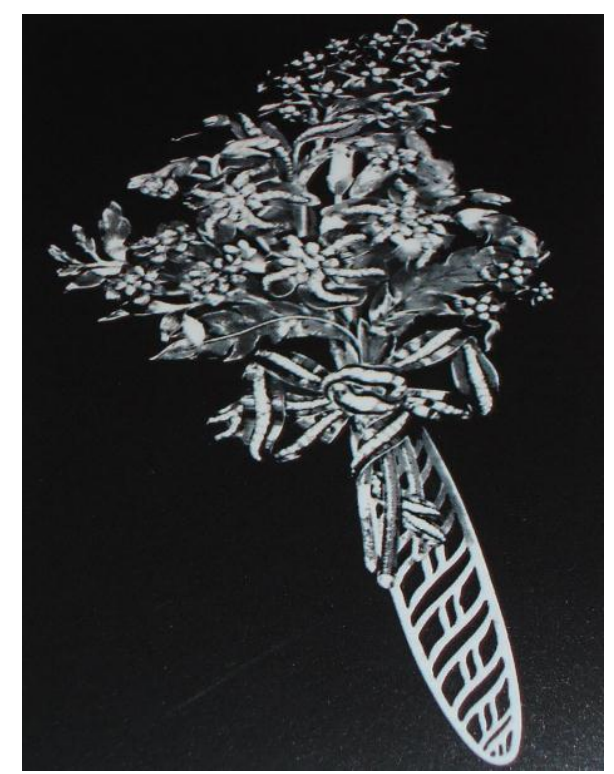

Figura 20. Broche floral, Espanha (séc. XVIII). Fonte: GOLA (2008) 


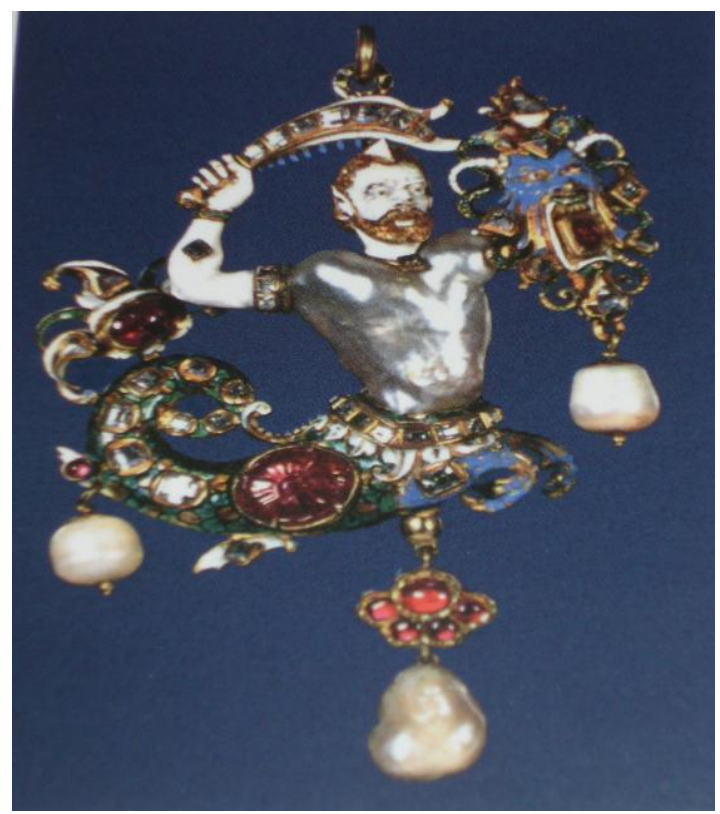

Figura 21. Tritão em pérola e pedras (séc. XVI). Fonte: GOLA (2008)

Já no século XVII, a feitura de joias estava voltada para o aprimoramento de técnicas, buscando-se mostrar as pedras com uma lapidação que propiciasse a refração da luz. Nos séculos seguintes, o panorama na Europa foi diverso, seguindo as tendências intelectuais, culturais, religiosas e da moda (GOLA, 2008).

\begin{abstract}
A descoberta da América permitiu verificar que os Astecas e Incas, notadamente, utilizavam desde séculos o metal extraído de suas minas juntamente com a prata. Os espanhóis rapidamente iniciaram sua exploração no Novo Continente. O fluxo de ouro que então se encaminhou para a Europa, procedente da América, quer o resultante dos saques espanhóis, quer o produto das minas exploradas pelo trabalho escravo, constitui inegável marco na evolução da história do metal (METAMIG, 1981, p.15 e 16).[...] a história da descoberta do ouro no Brasil está em íntima relação com as primeiras entradas dos habitantes do litoral no interior do País.[..] só cinquenta anos depois da descoberta é que se começou a informar mais intensamente a respeito da existência de ouro no território brasileiro (p. 24).
\end{abstract}

Com a revolução industrial e o consequente desenvolvimento de maquinários para a produção em massa e de técnicas para banhos de ouro em peças decorativas e em semijoias, o processo de produção em série fez com que a singularidade das joias ficasse em um segundo plano. Então, o ofício de ourives 
tomou outros rumos; mas, ainda assim, como atividade artesanal, resistiu ao modelo industrial, pois certas técnicas e habilidades inerentes ao ofício são insubstituíveis pela máquina (ver Figura 22). Além de confeccionar joias exclusivas e réplicas por encomendas ou de realizar consertos em peças em geral, o ourives encontrou espaço de atuação na atividade industrial pela terceirização de serviços (ANDRADE, 2008). Vale, aqui, destacar que no Brasil o ourives realiza todas as etapas de confecção de uma peça, o que não é típico de um processo industrial em que cada etapa é realizada por diferentes profissionais. $O$ fato de o ourives estar atento a todas as fases de produção de uma peça diminui os riscos de erros provenientes da fragmentação do trabalho.

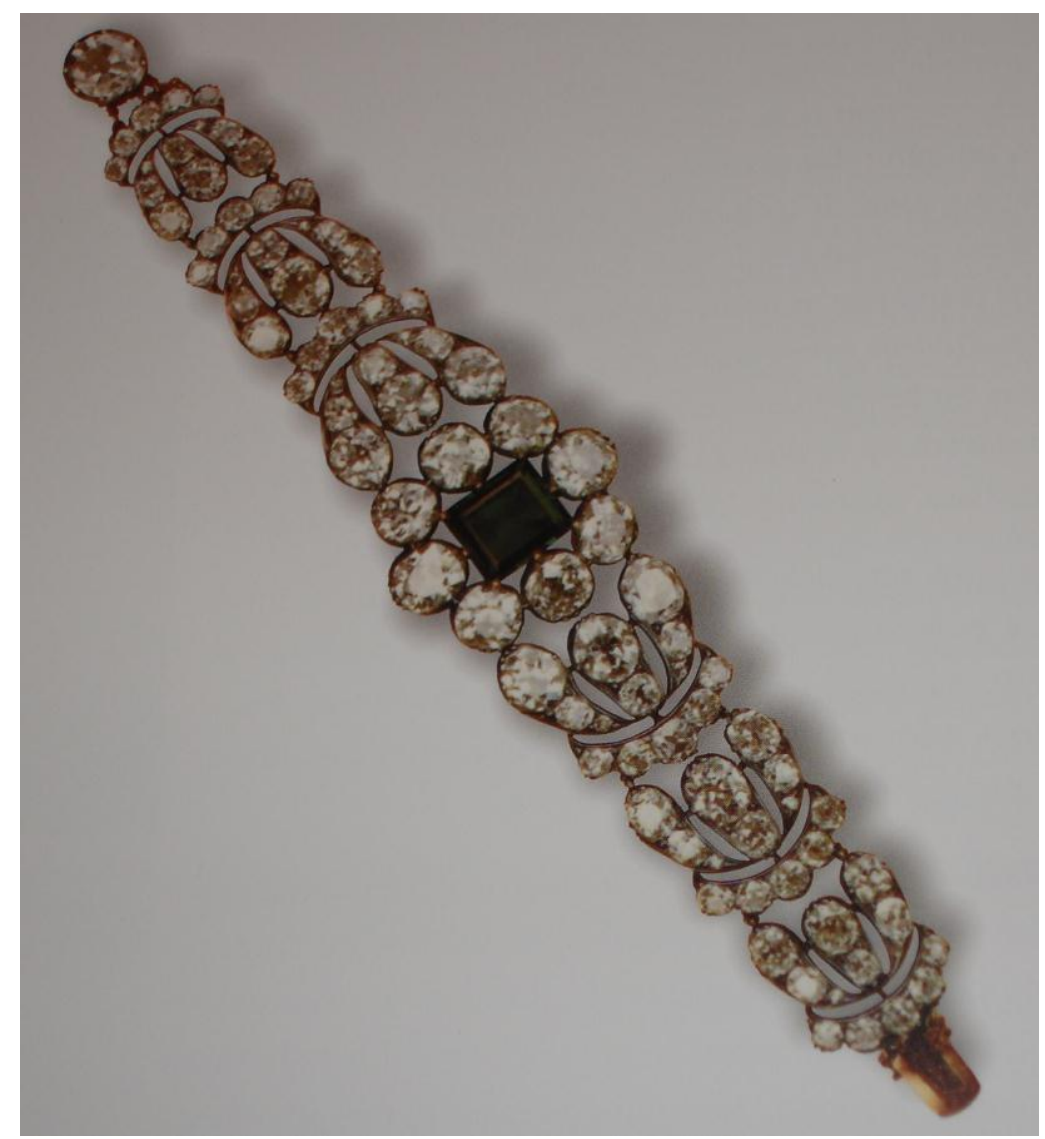

Figura 22. Bracelete com diamantes e esmeralda (1820). Fonte: GOLA (2008)

Junto com a revolução industrial, a atividade de joalheria foi escolarizada, surgindo no mercado o designer de joias, que atende às necessidades de disputas do ramo. Esse novo profissional tem a responsabilidade de projetar e criar peças 
artísticas, joias inovadoras, que se diferenciem e atendam às demandas mercadológicas. Para que esse ramo continuasse a crescer, foram criadas escolas especializadas para formação rápida de profissionais com noções básicas de técnicas e de matérias primas que envolvem a atividade de ourives (NOGUCHI, 2003).

Entretanto, o designer de joias necessita desenvolver certas técnicas e habilidades para materializar o seu projeto, mas que somente a vivência da ourivesaria propicia. Saber manusear matérias-primas, metais e pedras e dominar as técnicas em todas as etapas de fabricação influi na materialização do projeto que o designer idealizou. Para que o projeto de uma joia seja considerado de qualidade é preciso que a sua idealização seja executável. Noguchi (2003) alerta para o fato de que muitos projetos premiados e aparentemente bem elaborados mostram-se inviáveis, pois não são pensados em unidade com a sua execução, necessitando, para isso, de adaptações. Diante disso, estudantes de design costumam procurar mestres do ofício.

A história da ourivesaria retrata que, para se tornar um oficial, o aprendiz de ourives convivia com seu mestre por muitos anos de sua vida. Ele acompanhava seu mestre e seguia seus ensinamentos, passando por todos os processos de produção, da concepção à execução. Durante os anos que se seguiam, o aprendiz deveria desenvolver os conhecimentos e habilidades necessárias para o domínio das técnicas e para ser considerado um bom profissional.

Como afirma Sennet (2009), a casa do artífice, mestre do ofício, era a própria oficina. Na Idade Média, os dois espaços misturavam-se e a relação pessoal era bastante estreita. O mestre medieval tinha autoridade a ponto de ser tratado como substituto do pai dos jovens que recebia, tendo, inclusive, "o direito de punir o mau comportamento com violência física" (p.77). Também tinha a incumbência de educá-los e de desenvolver neles as habilidades necessárias do ofício. Um contrato era efetivado entre o mestre e os pais do aprendiz. Nele, constava o tempo de duração do aprendizado, geralmente de sete anos, e os custos que ficavam a cargo dos pais. Para isso, o mestre fazia um juramento religioso e sua autoridade se constituía por ele ser cristão, pois o cristianismo primitivo protegia a dignidade do artífice. O comportamento ético fazia parte de seu trabalho técnico. Cabia, também, ao aprendiz jurar preservar os segredos de seu mestre. 
A instrução centrava-se no princípio da imitação, em que o aprendiz deveria seguir as orientações do mestre na realização de uma tarefa e compreender de forma ampla todo o processo do ofício da ourivesaria. O veredito do mestre era definitivo e se o aprendiz pudesse substituí-lo, então, ele poderia ser transferido "de cidade em cidade como jornaleiro (competência gerencial e demonstrar merecer confiança como um futuro líder)" (SENNET, 2009,p.73). Nos dias de hoje, conservou-se muito da tradição medieval, conforme será visto nos relatos dos dois ourives que participaram do presente trabalho.

\section{Ourivesaria hoje: informações gerais}

Foram entrevistados dois mestres do ofício, aqui denominados William e Álvaro - nomes fictícios, pois suas identidades foram preservadas -, a respeito do trabalho que realizam e observada a sua atividade in loco, na confecção de peças, consertos, banhos, soldagem, fundição e purificação do ouro. Apesar da purificação do ouro não fazer parte da profissão, conforme afirmou o ourives William, tem que fazer né, se não tem ouro bom.

Segundo informaram os ourives William e Álvaro, eles não concluíram o ensino fundamental; aprenderam o ofício com um ourives experiente, ainda adolescentes. William, natural do estado da Bahia, após aprender o ofício veio trabalhar em parceria com seu mestre durante muitos anos, até montar sua própria oficina. Exerce a profissão há trinta e oito anos e, quando necessário, atende à solicitação do seu mestre e colega de ofício para auxiliá-lo em algum trabalho. Álvaro, natural do estado de Goiás, exerce a profissão há trinta e quatro anos; trabalhou em três oficinas de ourivesaria e empresa de joalheria até montar sua própria oficina. Ambos os ourives relataram que aprenderam as técnicas no exercício do ofício e salientaram a necessidade de estudar o serviço a ser realizado para o emprego correto da técnica e da matéria-prima, como dizem a seguir: 
[...] a profissão de ourives é uma profissão que você nunca aprende ela, você está sempre aprendendo uma novidade. Você está sempre aprendendo porque vai modernizando as joias antigas, que a gente nem fabrica mais. Hoje em dia, tem peca que você otha pra ela e nem sabe por onde comecar. Tem que estudar $\sigma$ servico, ver como é que é que vaí fazer [...]., Othando o modelo, o mostruário, descobrindo a forma e aprendendo de novo a manha de como fazer. [...] Todo dia tem uma coisa diferente pra você fazer. (William)

[...] é na atividade fazendo, no dia a dia, vaí aprendendo um pouquinho de um, um pouquinho de outro, observando e desenvolvendo técnicas pra facititar... ébem artesanal. (Álvaro).

Álvaro ressaltou a necessidade de estudar formas e modos de realizar uma técnica e de desenvolver tecnologias para adaptar ferramentas, para que o trabalho ocorra com mais precisão e rapidez.

Foram realizadas várias observações e entrevistas com cada um, separadamente, perfazendo cerca de um total de 18 horas e 50 minutos de conversa e observação (10 horas e 40 minutos para William e 8 horas e 10 minutos para Álvaro). As entrevistas foram realizadas na própria oficina em que trabalham. Não havia um roteiro de perguntas organizado previamente. Eles trabalham em oficinas distintas e a pesquisadora procurou cada um deles, apresentou-se, informou sobre 0 que desejava realizar e perguntou-Ihes se aceitavam colaborar. Tendo o consentimento, agendou com cada ourives, previamente, por telefone, uma sessão de conversa e, ao chegar ao local, propôs questões que qualquer pessoa interessada na atividade do ourives faria, procurando sempre manter o diálogo, orientando-o no sentido do maior detalhamento possível das informações que eram apresentadas no desenrolar do trabalho.

A oficina de William localiza-se em área comercial do Plano Piloto de Brasília. É uma sala pequena com um banheiro, dividida por um balcão, separando a saleta de espera e o espaço de trabalho. Há uma janela que dá para um vão entre salas. A porta de entrada que é protegida por uma grade com tranca automática. $O$ ambiente é arejado e a iluminação natural é pouca, o que requer o uso de 
luminárias. No balcão, há espaço para guardar matéria-prima, ferramentas, material de uso para estoque e o cofre. A pia do banheiro é utilizada para limpeza das peças. Apesar de o ambiente ser arejado, o ar não circula muito, para não interferir nos processos da fabricação e nem ocasionar a perda de matéria-prima, como o pó de metais nobres e outros resíduos, que ficam sobre a bancada e são depositados na sua gaveta. No espaço de trabalho há duas bancadas com luminárias, plataforma e gavetas.

A oficina de Álvaro localiza-se em centro comercial do Plano Piloto de Brasília. É um espaço amplo com vitrine para exposição das peças e duas salas divididas por uma parede de vidro que não possibilita a visualização do interior da segunda sala. A sala de espera é maior, com sofás e uma mesa para a recepcionista. Uma parede de vidro com bloqueador de visão separa um ambiente de outro. No espaço de trabalho, há janelas que abrem para o estacionamento do centro comercial, com uma bela vista e um exaustor. O ambiente é arejado e a iluminação natural é boa; mesmo assim, são utilizadas luminárias. Há armário sob a janela para guardar matéria-prima, ferramentas, material de uso para estoque, uma pia para limpeza das peças, um fogareiro elétrico. No lado oposto da janela estão as quatro bancadas com luminárias, plataformas e gavetas (ver Figura 23). Assim como a oficina de William, a oficina de Álvaro é arejada e ventilada, mas o ar não circula muito para não interferir nos processos da fabricação e nem ocasionar a perda de matéria-prima, tais como o pó de metais nobres e outros resíduos.

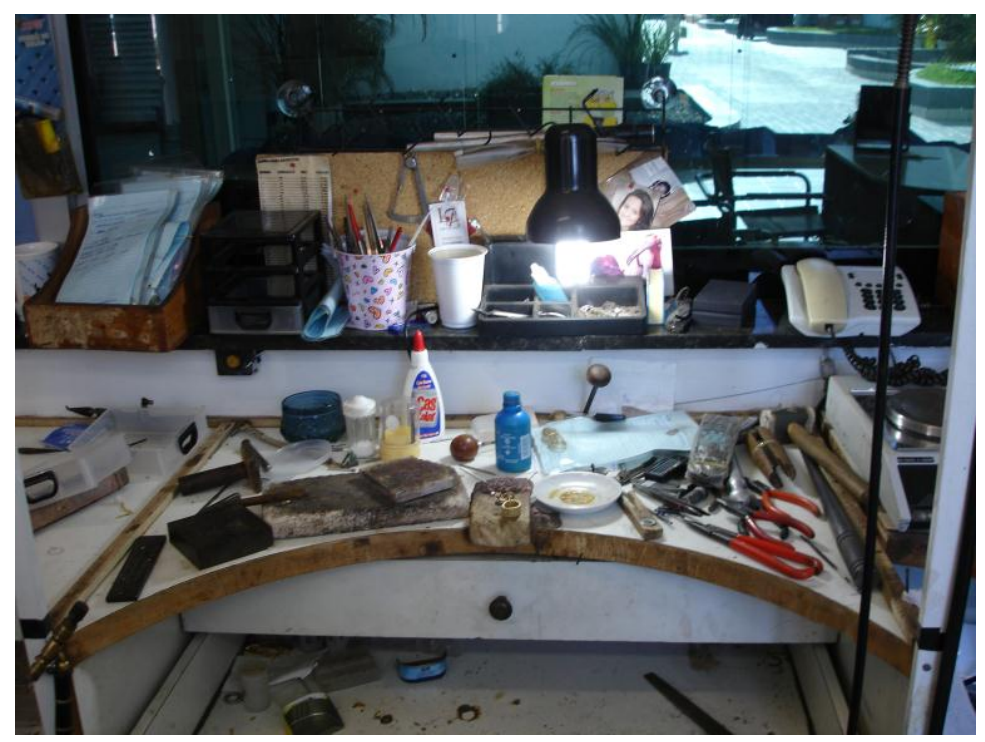

Figura 23. Bancada de trabalho da oficina de Álvaro. Fonte: fotografado em 26/07/2012 
O maquinário utilizado pelos dois ourives compreende laminador, politriz (máquina de dar polimento), balança de precisão, maçarico, alargador, máquina de aumentar alianças, ultrassom, fonte (para banho e eletrólise) e uma mesa de apoio com a caixa de fundição (ver Figuras 24 a 29). O que diferencia as duas oficinas é a quantidade de bancadas, pois na do Álvaro há quatro bancadas, todas equipadas para o trabalho de seus aprendizes.

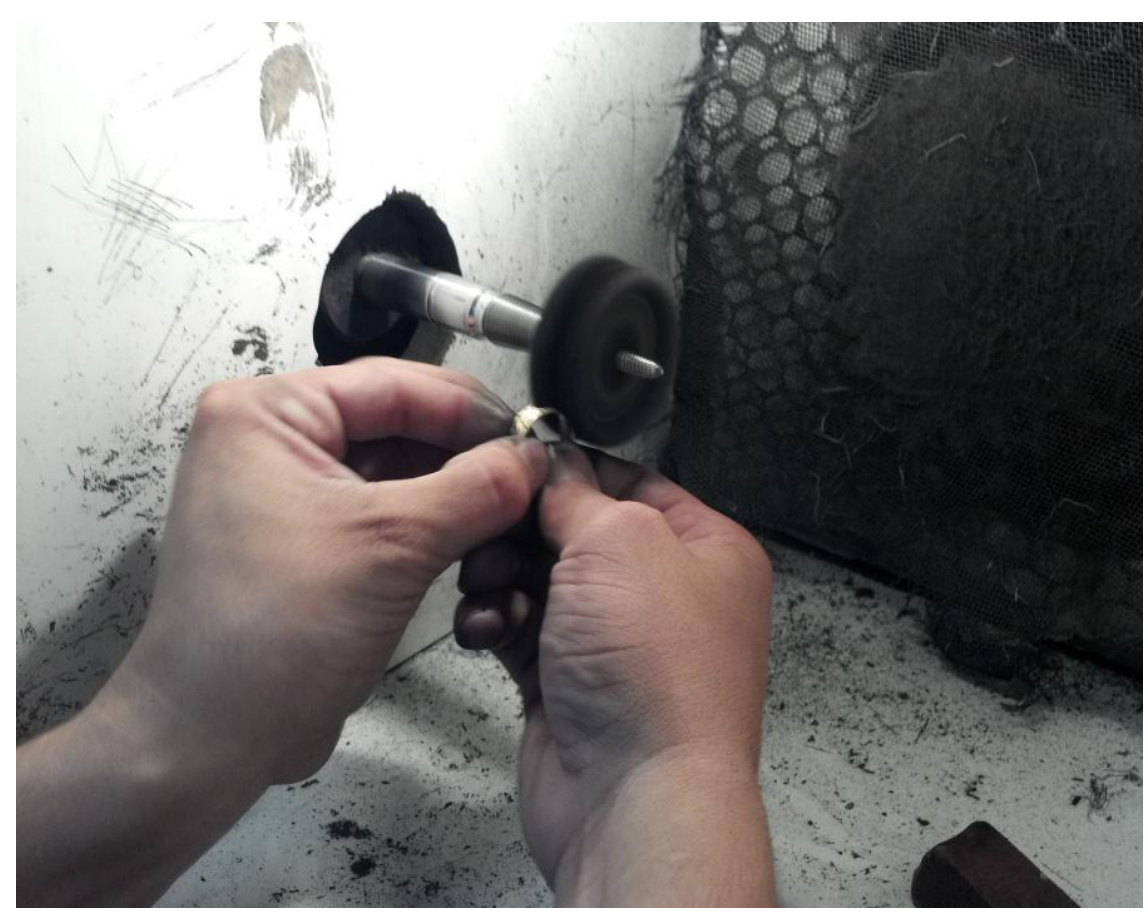




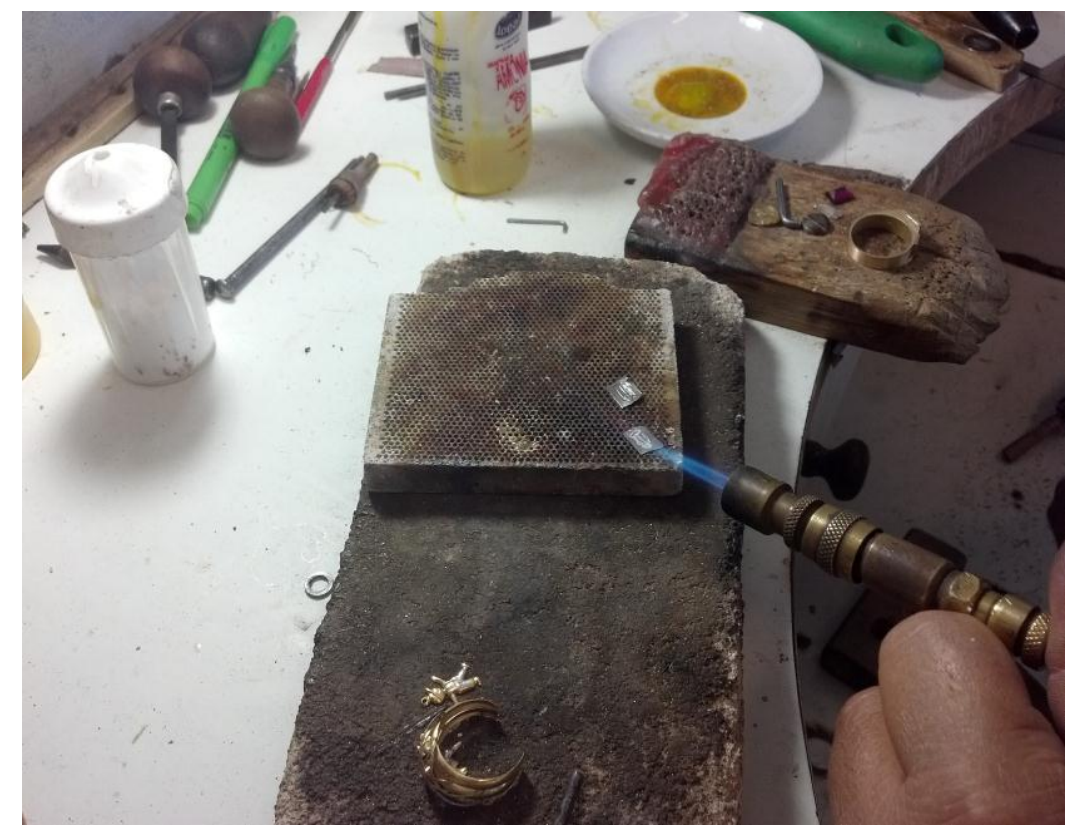

Figura 25. Maçarico.

Fonte: fotografado em 26/07/2012

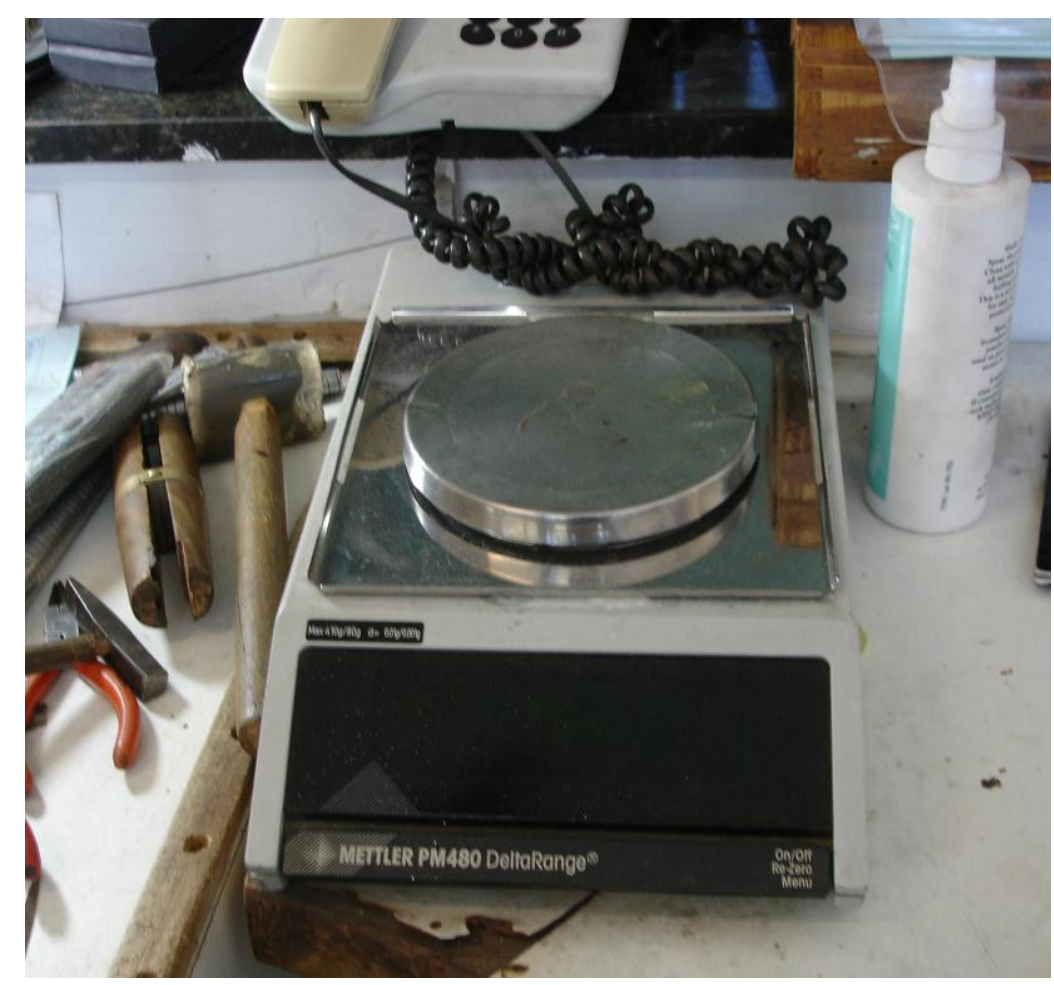

Figura 26. Balança .

Fonte: fotografado em 26/07/2012 


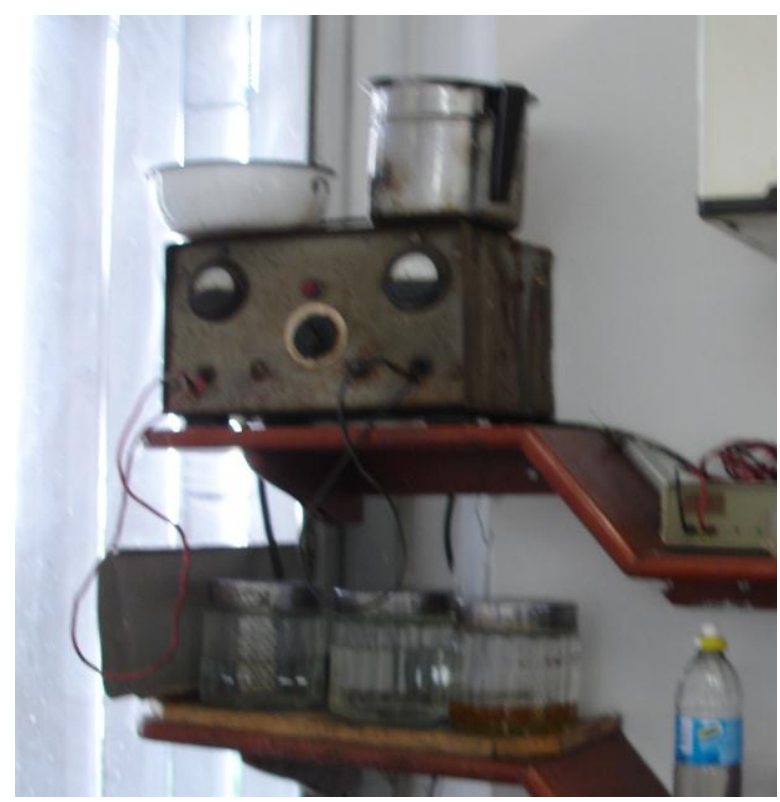

Figura-27. Equipamento para eletrólise.

Fonte: fotografado em 26/07/2012

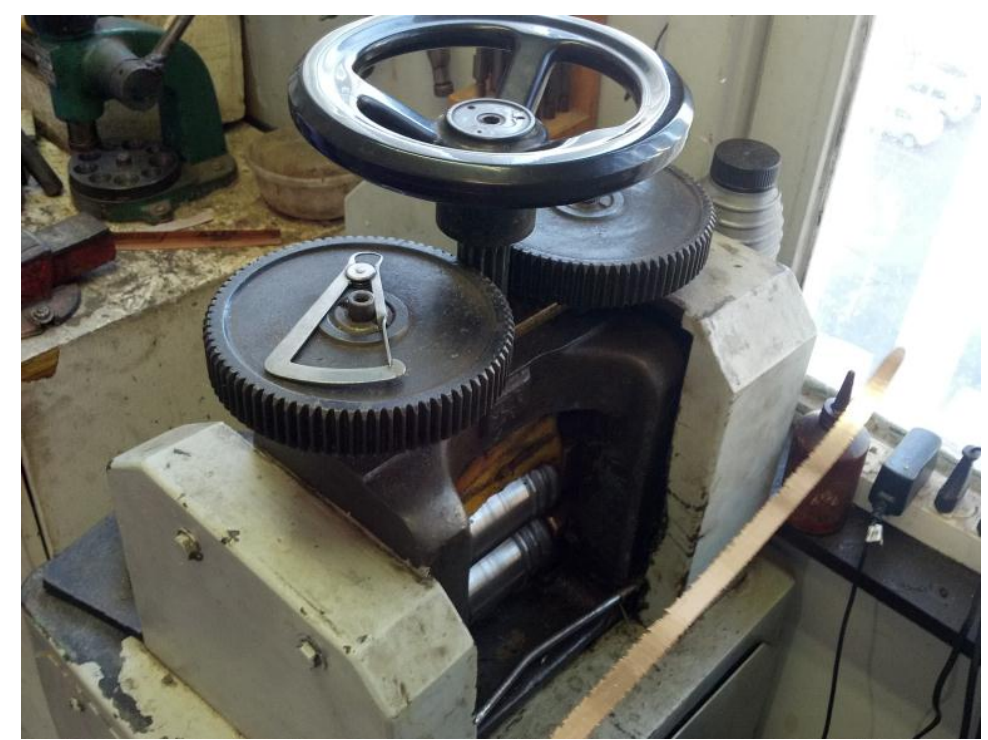

Figura 28 Laminador, paquímetro e o ouro laminado. Fonte: fotografado em 26/07/2012 


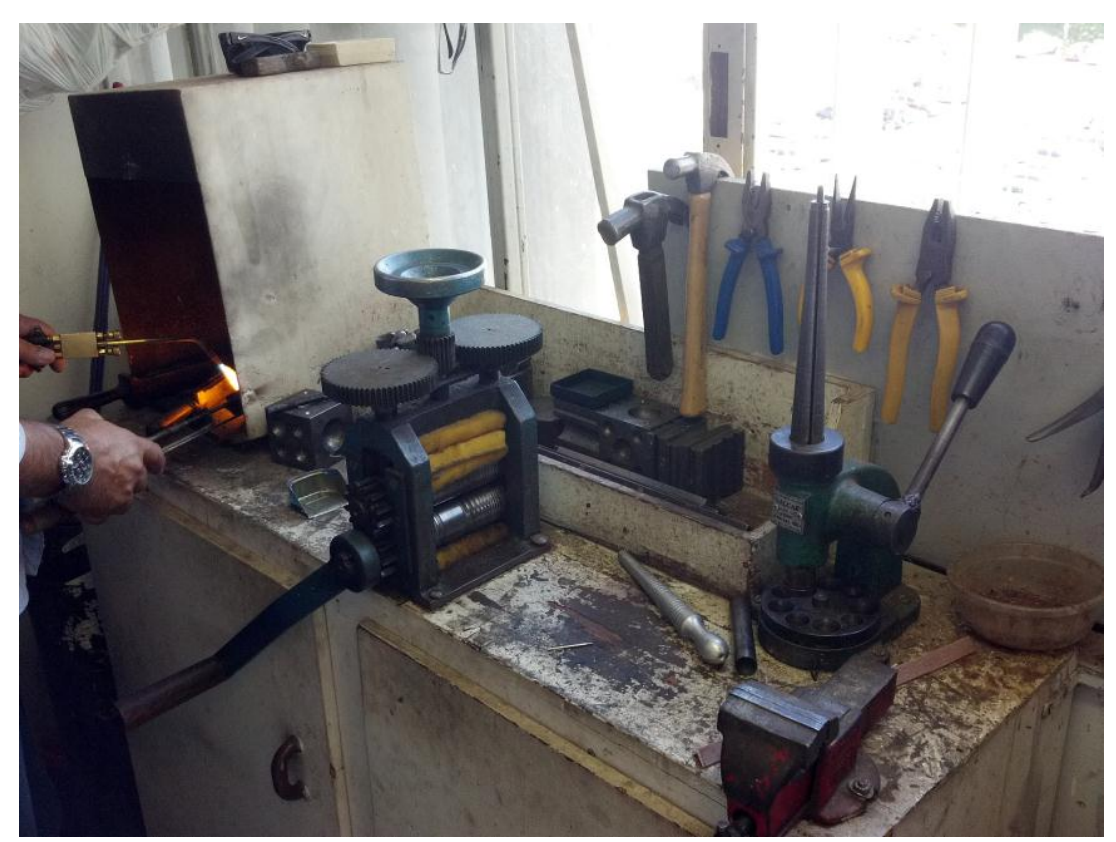

Figura 29. Laminador, alargador, caixa de fundição, maçarico, suporte de cadinho, aneleira, martelos, dado de bolas, alargador de aliança.

Fonte: fotografado em 26/07/2012

As ferramentas mais utilizadas são: lupa, alicates, martelos, limas, lixas, tesouras, bigorna, paquímetros, compassos, arco de serra modulado, serras, escovas; as utilizadas por dentistas, como pinças e brocas; espátulas, tribulé, buril, grifador, fieira, cadinho, suporte para o cadinho, releira, morsa de mão, toco de madeira para cravação, queijinho de símbolos, aneleira, dado de bolas, pedra de toque, bastão de medidas de anéis e outras que são criadas pelo ourives devido à necessidade que a peça requer para sua feitura (ver Figuras 30 a 37). $O$ trabalho singular do ourives, na confecção de uma peça, traz desafios que exigem dele a criação de ferramentas adequadas. 


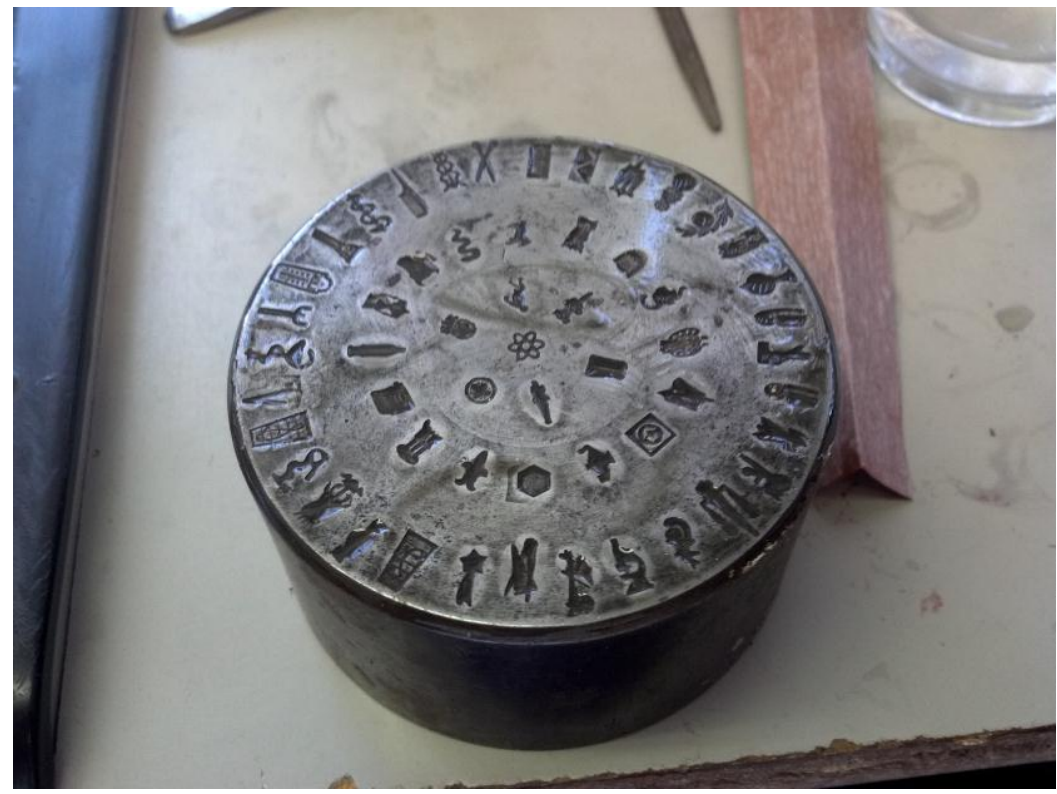

Figura 30: queijinho de símbolos.

Fonte: fotografado em 26/07/2012

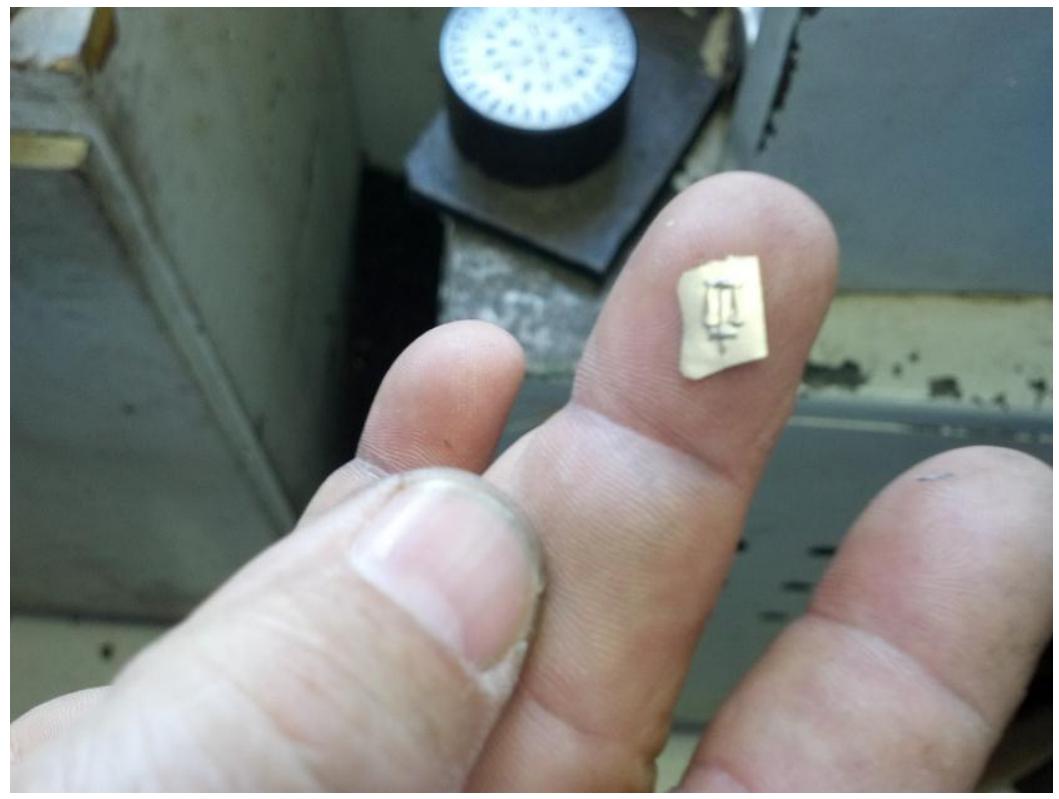

Figura 31. Símbolo do Direito.

Fonte: fotografado em 26/07/2012 


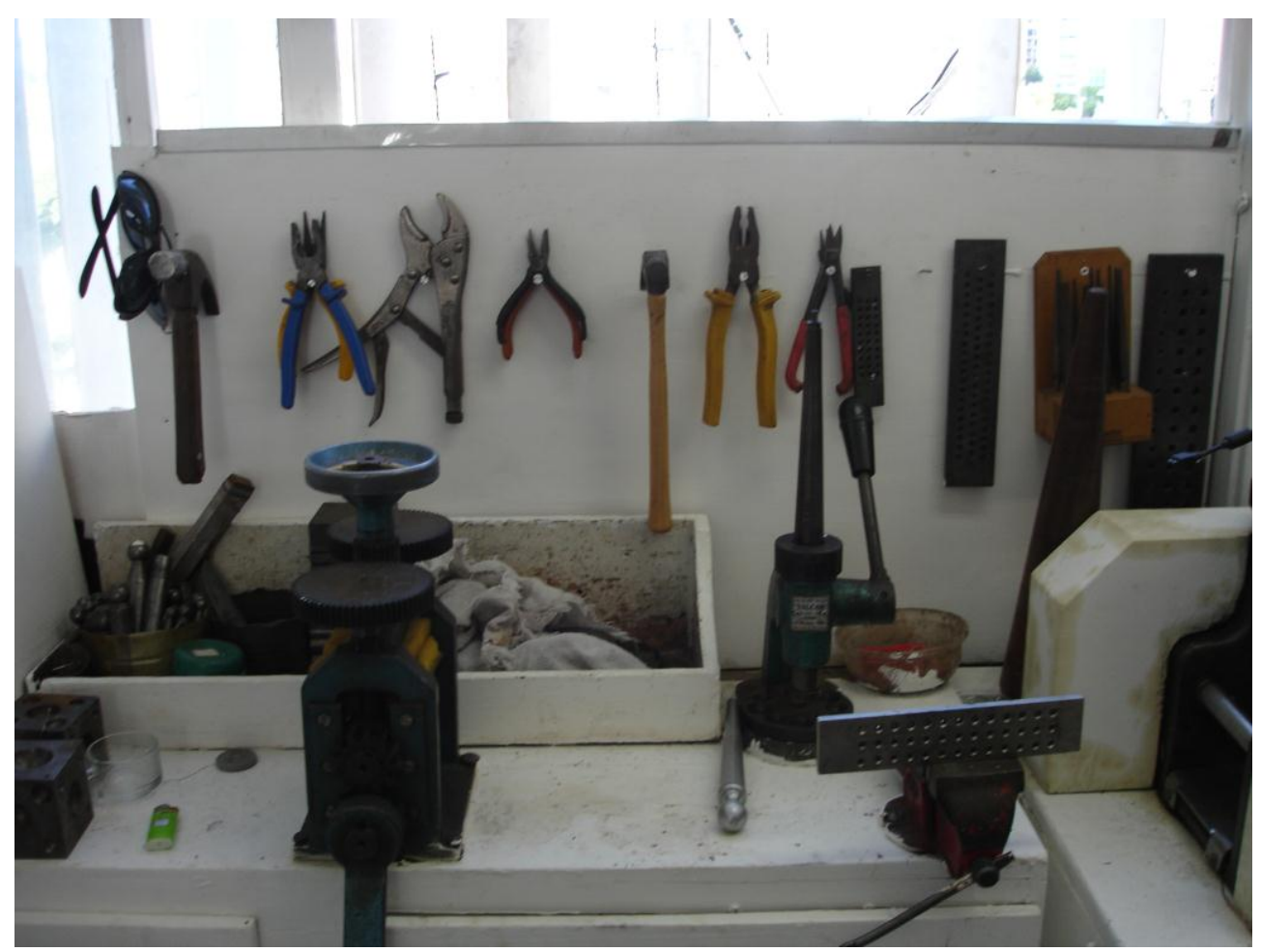

Figura 32. Alicates, martelos, dados de bolas, fieira, alargador, aneleira, tribules, dados de bolas. Fonte: fotografado em 26/07/2012

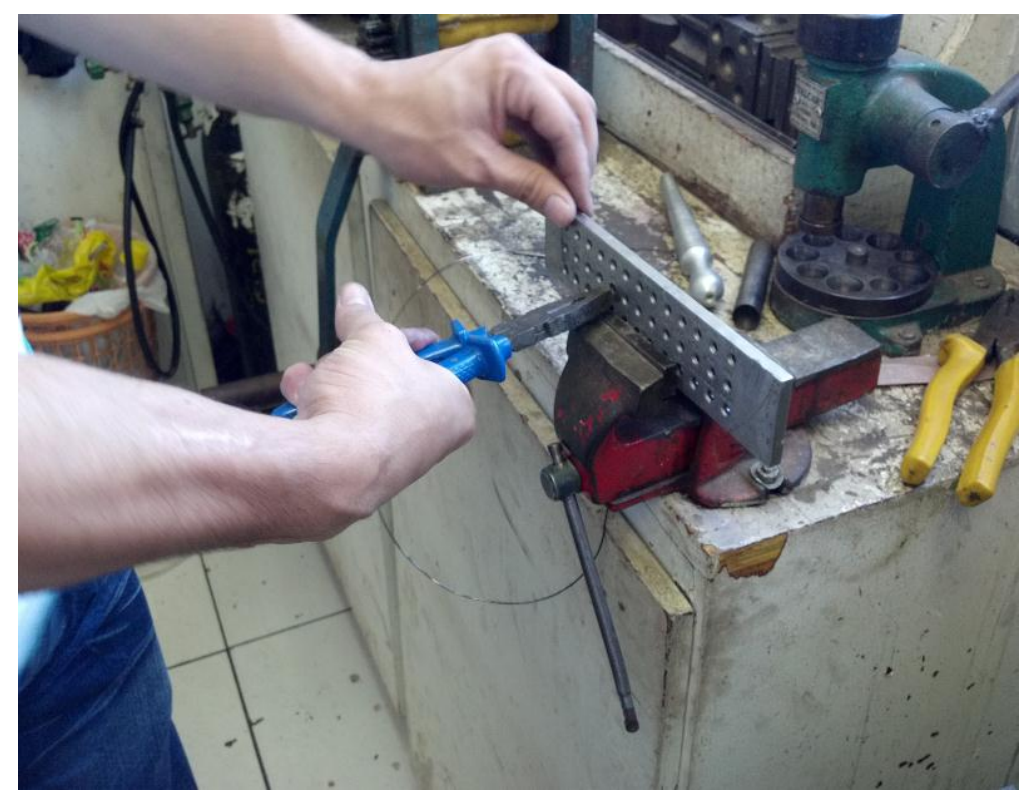

Figura 33. Fieira.

Fonte: fotografado em 26/07/2012 


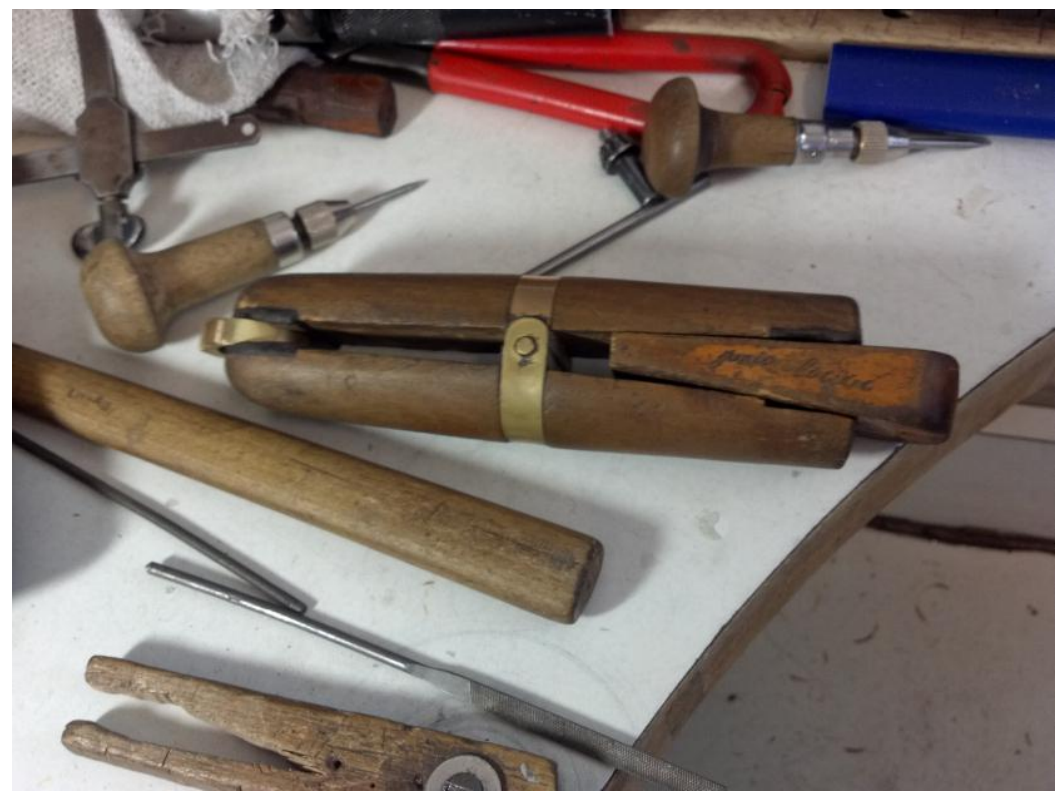

Figura 34. Morsa de mão.

Fonte: fotografado em 26/07/2012

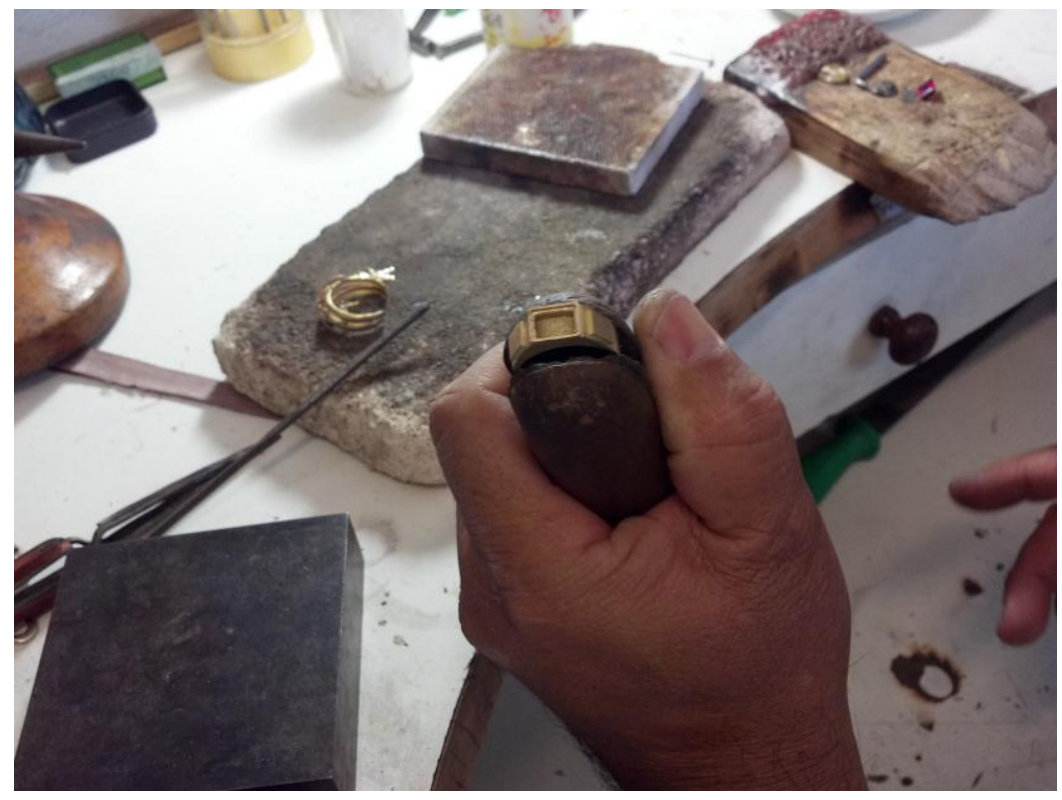

Figura 35. Anel na morsa para cravar a pedra. Fonte: fotografado em 26/07/2012 


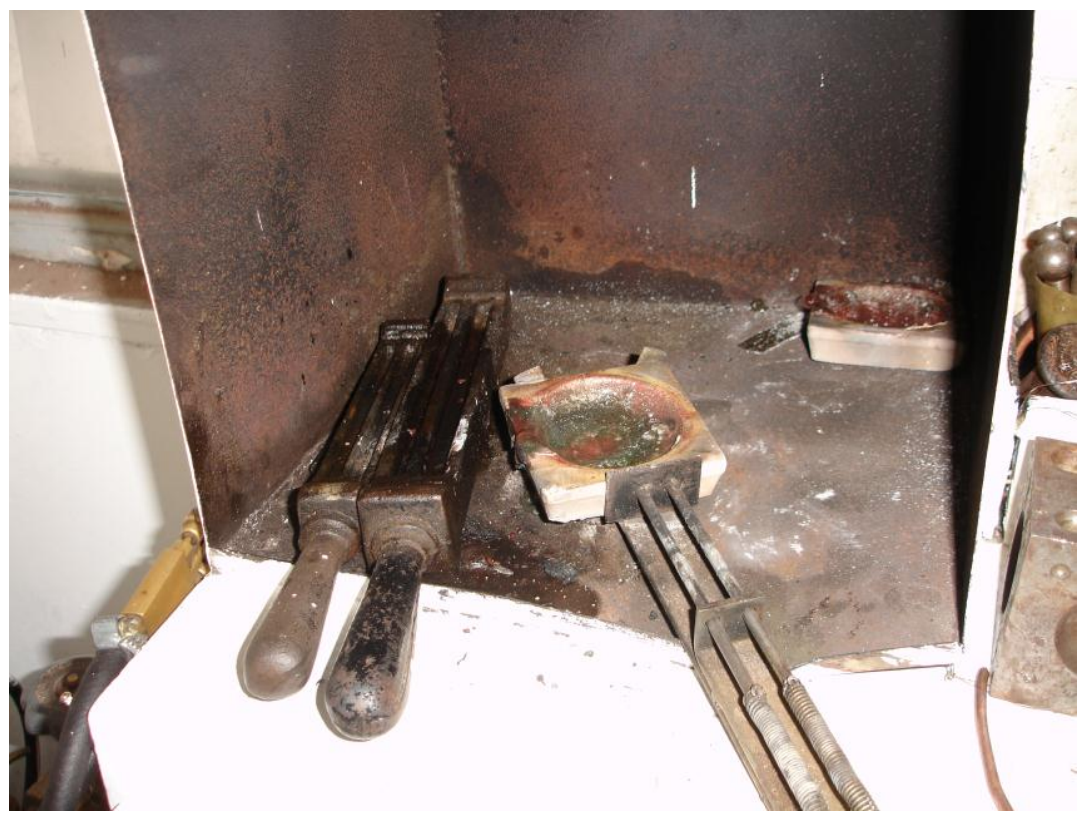

Figura 36. Suporte de cadinho, cadinho e releira. Fonte: fotografado em 26/07/2012

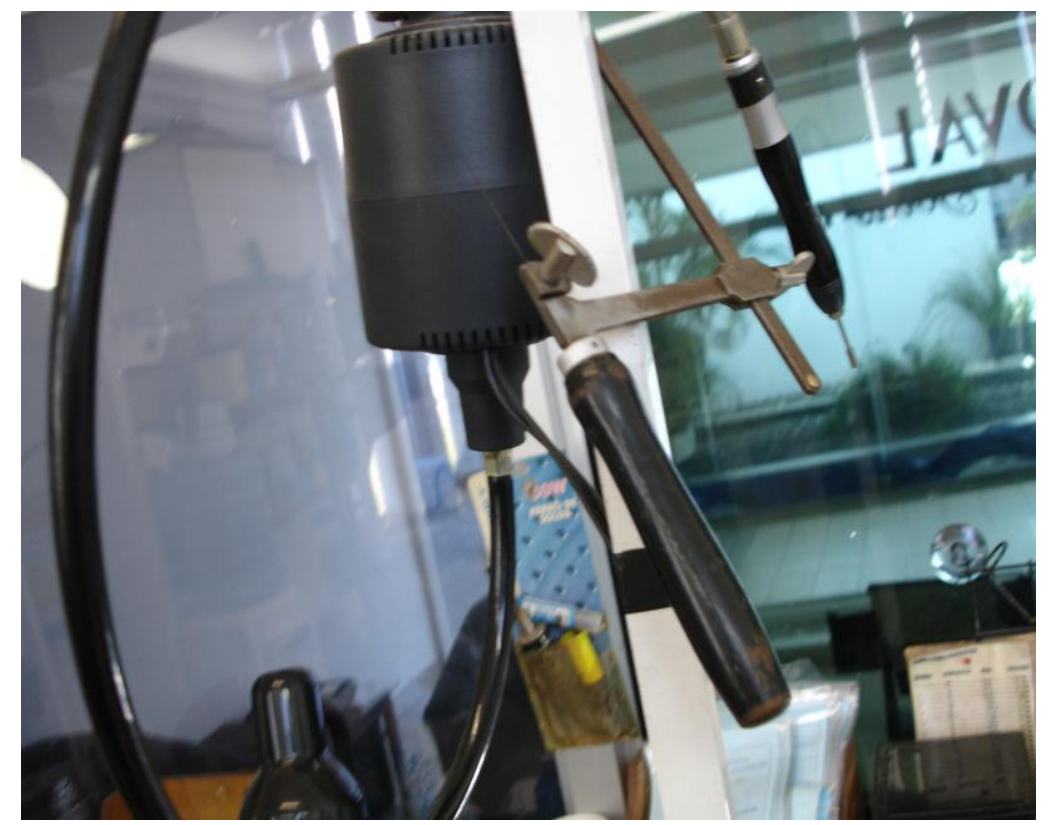

Figura 37. Arco de serra e broca. Fonte: fotografado em 26/07/2012 
Os problemas do ofício apontados por William são: queimaduras, intoxicação, enfraquecimento da visão pelo uso constante dos óculos de lente de aumento, ardis e trapaças de clientes e assalto. Álvaro relatou que sofreu intoxicação por duas vezes, sendo que é comum a alergia e a visão comprometida pelo uso constante dos óculos de lente de aumento. Ele acrescentou que orienta e insiste para que seus aprendizes usem o jaleco fornecido por ele e as máscaras. Apesar dos riscos à saúde, ambos os ourives confessaram não utilizar luvas e máscaras.

A formação de um ourives, conforme relato de ambos, acontece em uma relação direta do aprendiz com seu mestre, no próprio exercício do ofício. Não há exigências prévias para o início e nem um tempo estipulado, antecipadamente, para determinar se o aprendiz está apto ou não para exercer o ofício autonomamente.

Álvaro, atualmente, possui cinco aprendizes: três adolescentes, uma designer de joias e o seu sobrinho, que havia trabalhado com ele quatro anos antes. Informou que incentiva experiências extras em outros locais e o desenvolvimento da independência profissional. Acrescentou ainda:

Depois de um ano, fateí pra ele [o sobrinho] dar uma andada pra ver como tá sua capacidade. E ele voltow agora, tem dois meses. Fícow três anos fora. Já volta em outro padrão, já volta na montagem, seguindo... Eu falo pra eles: - Se não gostar, não adianta. Tem muito oquerer da pessoa.

Quando perguntado a respeito da avaliação do aprendiz, respondeu:

Tenho um teste comigo mesmo. É a solda, técnica que ew aprendi. Porque na época o que ew achava mais dificit era soldar ... pega um fio de cabelo, uma correntinha pra soldar, tem que soldar pra ficar perfeito. Então, a gente pega uns fios de cobre pra poder soldar; ele passa de um fio 0,80 até 0,10, que é a grossura de um 
fío de cabelo. A gente vê a possibitidade da pessoa soldar. Vamos treinar essa solda aqui. Então, você vai, começa a fazer alguns pequenos consertos, você vaí vendo o visual, a linha, vaí observando.

Em um dos encontros, William contou que ensinou o ofício para diferentes pessoas, sendo uma delas a embaixatriz do Japão, que desejava fazer suas próprias joias. Atualmente, ele está sem aprendiz, apenas com um de seus filhos que $o$ auxilia no serviço de polimento.

Em linhas gerais, segundo informaram, a relação mestre-aprendiz ocorre do seguinte modo: ao receber uma encomenda, o mestre chama o aprendiz para acompanhar o trabalho e, na oficina, juntos avaliam cada etapa da confecção da peça. À medida que o aprendiz se desenvolve, o mestre atribui-lhe as tarefas relacionadas ao projeto da joia que, aos poucos, se materializa. São tarefas realizadas "para valer", na própria execução do projeto: soldagem, banho, purificação do ouro, limpeza, polimento, reparos e modificações. Se acontecer algo fora do previsto e do desejado, isto é, se um deles errar - fato que, evidentemente, é mais esperado acontecer da parte do aprendiz - o trabalho é desfeito e a etapa, refeita. Ou seja, pelo que se pode apreender, o mestre não teme o erro a ponto de tornar artificial com simulações a tarefa de aprendizagem. $O$ erro do aprendiz é tratado como um acontecimento próprio da atividade e que pode ser corrigido.

A relação mestre-aprendiz no ofício de ourives é bastante interessante. Apresenta desdobramentos importantes no processo de instrução e formação e na relação do aprendiz com a sua atividade profissional. No enfrentamento de problemas que venham a surgir no desenrolar da fabricação da peça, o aprendiz tem a possibilidade de avaliar todo o processo, rever as estratégias adotadas, identificar os erros e constatar que deve recomeçar, ou seja, desmanchar a peça e começar tudo de novo. Lidar com o erro como uma possibilidade de instrução rompe com a ideia do erro vinculado ao fracasso, como costumeiramente acontece no espaço escolar. Cada peça é um novo desafio a ser alcançado. 
O ourives Álvaro tem o desejo de se dedicar ao ensino do ofício para jovens carentes, mantendo a sua metodologia de trabalho. Sua intenção é transmitir conhecimento da ourivesaria para que jovens possam ter uma profissão e "ganhar a vida", como diz. Entretanto, necessita de estrutura física e de recursos para tal. Assim ele comenta:

Eu quero, como diz o outro, final da vída, só ensinar. Ensinar é diferente, você ensina alguma coisa, você aprende, é só falando. Pegar uma turma de 10, 15 alunos por ano [...] uma oficina dessa aqui, bem montada, com essa estrutura toda... é como se fosse pegar essa loja aqui, desativasse ela e montasse várias bancadas. Dá certinho! Já fiz o projeto, dá certinho. Por enquanto, não posso mexer com isso não. O cara do SEBRAE queria que en fosse dar aula lá. Tó preocupado com isso ainda não; tenho meus compromissos ainda. Falei que ainda não. [...] $\mathcal{O}$ que precisa fazer é ajudar criancas da comunidade carente, é profissionatizar. Mas, hoje, para você ter um negócio legatizado, você precisa do apoio do Governo. É uma burocracia muito grande. Com certeza, vai ter criancas carentes, que realmente precisa mesmo, é uma coisa que muda totalmente o futuro. [...] Eu tenho isso para mim. Inclusive, ew tenho um sonho... se ew tivesse recurso pegava um lote desses, fazia um galpão e dividia ele, até sair profissional lá de dentro. Hoje não anda [...] se não tiver apoí, não adianta. (Álvaro)

A profissionalização e a vivência do ofício pelo aprendiz possibilitam: o desenvolvimento do conhecimento das matérias-primas (o ouro, a prata, o cobre, o latão, a platina); a identificação das suas características para as ligas necessárias na fabricação de joias; o conhecimento das pedras preciosas e semipreciosas e de 
suas características para melhor trabalhar com elas; o conhecimento das funções e propriedades de ácidos, soluções e fluxos usados na fabricação de joias.

O trabalho diário na oficina exige do ourives muita concentração, pois uma pequena distração pode ocasionar alguma falha na concepção da peça ou mesmo um dano físico. Devido à larga experiência, ambos os ourives dominam as técnicas, esclarecem a respeito de cada serviço com tranquilidade e com domínio do conhecimento, e demonstram muita boa vontade em ensinar.

\section{A atividade do ourives e o pensamento conceitual}

Concluída a etapa do acompanhamento da rotina de trabalho dos ourives e da realização de entrevistas, as informações obtidas foram organizadas em mapas conceituais. Foi elaborado um mapa geral de cada ourives (APÊNDICES A e B). Construída essa primeira versão contendo todas as informações obtidas, cada mapa conceitual foi submetido à apreciação do ourives e corrigido no que fosse necessário.

O que se evidencia, em primeiro lugar, nos mapas conceituais dos dois ourives é quão complexa é a sua atividade. Ao realizá-la, eles precisam articular, de modos diferenciados e por diferentes critérios, inúmeros procedimentos, operações, conceitos e resultados. Em segundo lugar, os dois mapas conceituais, ainda que singulares, não mostram discrepâncias de vulto, nem contradições, quando comparados. Ao contrário, as semelhanças são notáveis, o que pode ser tomado como indicativo da precisão das descrições dos dois ourives.

No dia a dia, os ourives realizam vários serviços como modificações em peças, banhos, soldagem, polimentos, limpeza e purificação do ouro, como pode ser verificado na Figura 38, extraída do mapa conceitual geral de William. 


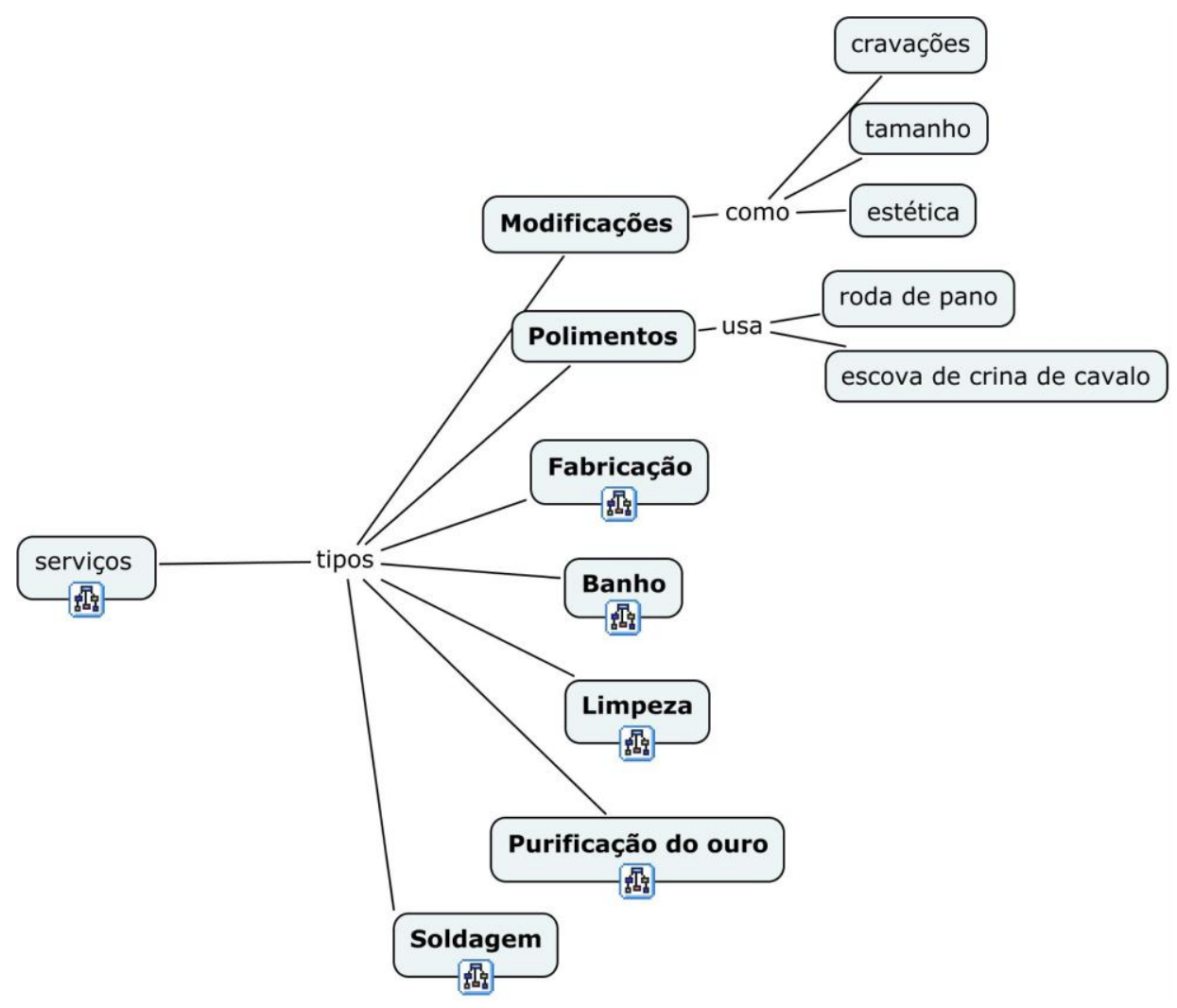

Figura 38. Célula extraída do mapa conceitual do ourives William que retrata os serviços prestados.

Conforme disseram os dois ourives, para cada peça a ser criada e materializada, eles estudam e planejam as estratégias de trabalho, pois não há uma padronização e automação do ofício. O que orienta o fazer é o projeto da peça e não propriamente a técnica em si. Eles precisam pensar qual a liga de metal será mais condizente, conforme a tonalidade do ouro, para o fabrico da joia pretendida.

Em sua atividade, manipulam materiais e substâncias químicas, cujas propriedades são deles conhecidas. Alguns provocam risco à saúde, seja pelo contato direto com a pele ou por inalação. Os ácidos sulfúrico e o clorídrico ou muriático são utilizados na limpeza das peças e manuseados diariamente. $O$ ácido nítrico é utilizado na purificação do ouro. Há, também, o fluxo soldaron, utilizado na solda, e o composto bórax ${ }^{22}$, na fundição. $\mathrm{O}$ cianeto de potássio ou cianureto de potássio é utilizado para o banho de ouro e para o eletropolimento, juntamente com o peróxido.

\footnotetext{
${ }^{22}$ Bóraxé outro fluxo de usar no ouro para fundir, conforme disse William.
} 
Ao acompanhar os ourives em seu trabalho, foi possível verificar o volume de detalhes e pormenores que constituem o seu fazer. São muitas informações articuladas e conceitos que ancoram o saber da ourivesaria. Se a peça produzida não estiver a contento, pois eles são bastante minuciosos, desmancham e fazem tudo de novo. Como eles mesmos afirmaram, a qualidade do serviço está atrelada à peça idealizada e ao sorriso do cliente.

Trata-se de um trabalho meticuloso que realizam com muita tranquilidade. Ambos demonstraram mais facilidade em explicar cada procedimento na atividade, enquanto a realizavam. Foi possível perceber que, na atividade, o projeto da peça, o planejamento do serviço e a sua execução constituem uma unidade, ou seja, não há uma separação entre o pensar e o fazer.

Outro fato que merece destaque é o cuidado que William e Álvaro têm para não haver desperdício de material, seja em relação aos ácidos e fluxos, seja com os metais manuseados. O pó dos metais que foram trabalhados e guardados, geralmente, na gaveta da bancada, é depositado no cadinho ${ }^{23}$. Sobre os metais depositados é colocado o bórax e passado fogo com o maçarico para unir o metal. Como esclareceu Álvaro:

Isso é bórax. Tem que ter ele, señ̃o o metal não funde. [...] quando comeca a dar fogo, ele forma uma liga, ele une o pó, para o pó não voar também. Oh!, tem pó aqui. Se eu colocar diretamente o maçarico aqui, o macarico é pressão, então, ele vaí voar.

Os restos dos líquidos utilizados no processo de purificação, limpeza e banho de peças são guardados para posterior decantação, processo que transforma o ouro líquido em pó que, depois, é fundido e purificado.

Os ourives explanaram, assim, a respeito dos metais preciosos:

\footnotetext{
${ }^{23}$ Cadinho é um recipiente de cerâmica utilizado para fundir metais e aguenta de 2 mil a 3 mit graus, conforme disse Álvaro.
} 
$\mathcal{O}$ ouro é classificado em 14,16,18,22 e 24 [quilates]. $O 18$ é o que a gente usa pra joia. Agora, o ouro inferior a isso [18] não é comercial. Quanto mais liga, mais baixo o ouro fica. $O$ ouro 22 quase não tem liga. $\mathcal{O}$ ouro 24 é puro, não serve pra peça. Tem que ligar ele pra 18, que é o 750. Pode fazer liga com cobre, prata, metal latão, dependendo da cor que quiser. Com metal latão fica mais esverdeado; o cobre fica mais avermelhado e $\sigma$ cobre com prata fica amaretinho, aquela cor de ouro itatiano. Para ouro 18, 25\% de liga cobre e prata e 75\% de ouro. Mas 750, para as fábricas é 33\% de cobre e prata e 67\% de ouro. Eu uso 30\% de prata e cobre que dá of 750. O ouro branco é fabricado com tiga do metal paládio, 20\% de paládio e 80\% de ouro. Para ficar bem branco, ew uso 3 pra 1, pra ficar um ouro bem methor, bem branquinho. (Wittiam)

É tabelado, controlado mundialmente. No Brasit, se trabalha com 18; o americano é 14; Portugal é 22 e na China só o 22. (Álvaro)

Para dar brilho com tom mais branco ainda, costuma-se dar banho de ródio, o que geralmente as joalherias fazem. Como o custo do aparelho próprio e do preparado é alto, pois eles são importados, na maioria das vezes, os ourives preferem não rodinar, isto é, não fazer banho de ródio. Outro metal muito utilizado na ourivesaria é a prata 925. Ambos os ourives comentaram não confeccionarem frequentemente peças em prata, pois ela dá mais trabalho que o ouro, não aguenta potimento igual ao ouro. Quando você aperta, ela escurece; se ela esquentar, escurece(Álvaro). Afirmaram, ainda, que o tempo para realizar o 
serviço em prata demora muito. Os acabamentos, o polimento tem que ser feitos lentamente à mão, detalhe por detalhe, apresentando, na maioria das vezes irregularidades. A prata não aceita o eletropolimento(William). Além disso, a margem de lucro é pequena. Há, ainda, a platina, que é utilizada pelo Álvaro em peças encomendadas por uma joalheria. Ele esclarece:

É o metal mais nobre que tem. Platina é maleável, não muda de cor. Quanto mais você dá fogo nela, mais ela britha. [...] é o metal mais puroque tem. (Álvaro)

Quando Álvaro foi perguntado sobre qual o metal que faz liga com a platina, respondeu que não sabia ainda, pois havia começado a trabalhar com esse metal recentemente, a pedido de uma joalheria.

Apesar da singularidade de cada joia, há procedimentos que se repetem, como verificar rapidamente a qualidade do ouro, fazendo um risco na pedra de toque e sobre o risco pingar-se o ácido de toque. Se o risco ficar amarelo forte, a liga é boa. Quanto mais fraco e sem cor for o risco, menor a qualidade da liga do ouro, conforme a Figura 39.

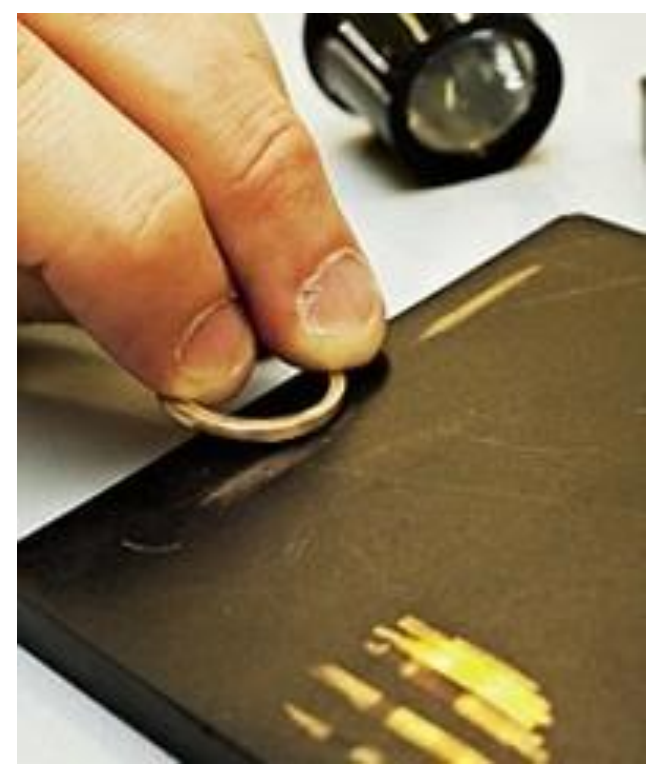

Figura 39. Pedra de toque

Fonte: Disponível em: <http://www.arlloufill.com>. Acesso em: 07abr. 2013. 
Tendo planejado as etapas de execução, o ourives inicia o serviço. Uma prática que é repetida em diferentes momentos, durante a produção da peça, para facilitar o trabalho, é o recozer, isto é, aquecer o metal por meio do maçarico. O recozer possibilita alterar a maleabilidade do metal de modo a facilitar o manuseio. É interessante destacar que, tanto para endurecer o metal (temperar) como para amolecê-lo (recozer), ele é aquecido; a diferença é que, se colocado no óleo, ele endurece e, se colocado na água, ele amolece.

Além de testar a qualidade da liga do metal com a pedra de toque, de atentar para a maleabilidade e recozer em diferentes momentos, há, ainda, as etapas de fundição, laminação, solda, cravação e montagem da peça, para posterior limpeza, e o polimento, última etapa de finalização do trabalho, conforme relato de William e Álvaro (ver Figura 40).

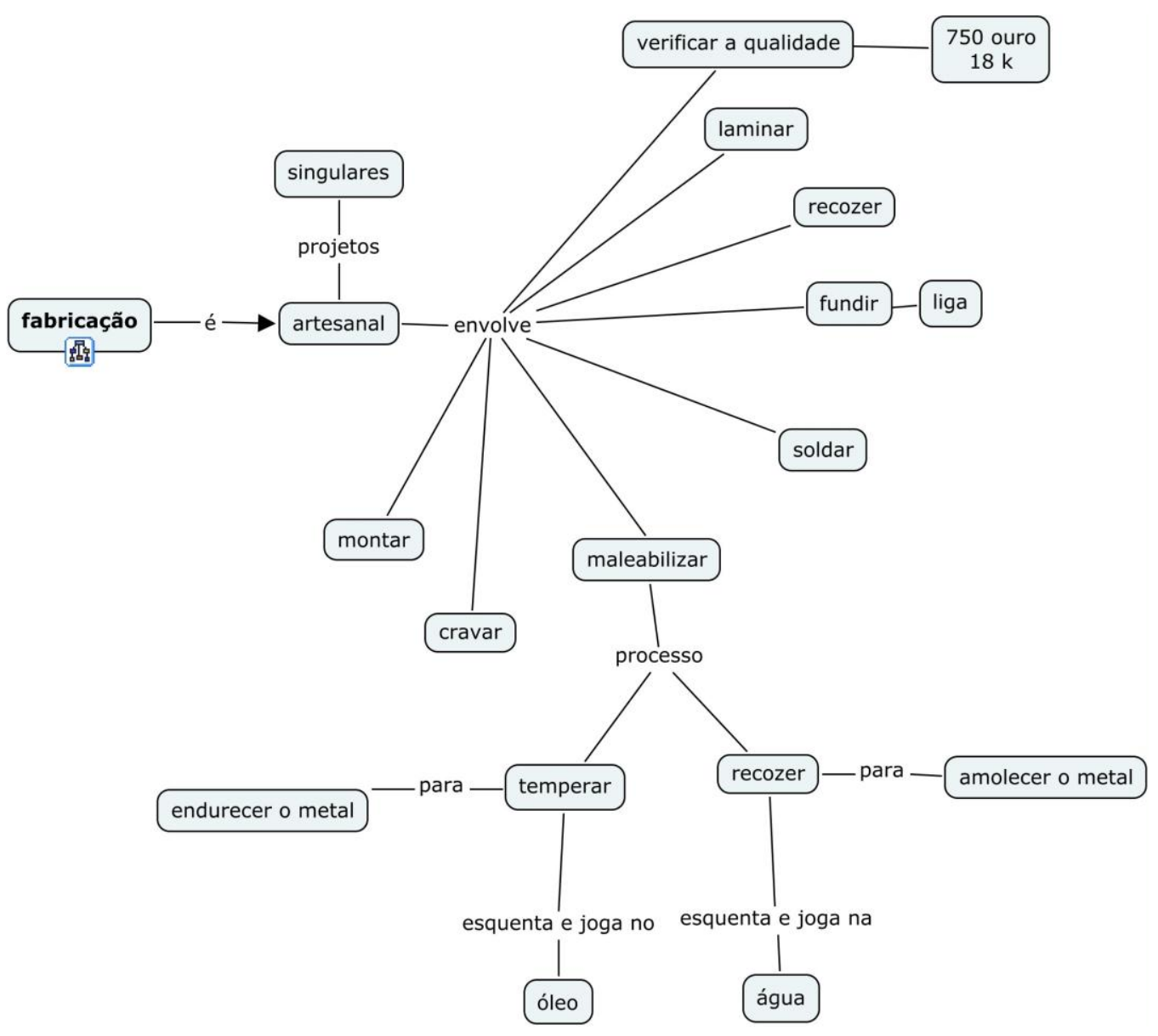

Figura 40. Célula extraída do mapa conceitual dos ourives Álvaro. 
Um serviço muito solicitado pelos clientes é o banho da peça em ouro. São bijuterias folheadas que descascaram e que o cliente deseja recuperar. Os ourives realizam o que denominam de banho simples, por meio do processo eletrolítico, com cianeto de potássio, água destilada e ouro líquido, que foi dissolvido em água régia ${ }^{24}$. Mergulha-se a pesca no liquido presa a um dos jacarezinhos para passar corrente elétrica; o outro jacarezinho [tem preso nele] uma linguinha de ouro, conforme relato de ambos os ourives, para o $1^{\circ}$ tipo de banho, conforme mostra a Figura 41. Álvaro emprega o termo jacarezinho e William, eletrodo.

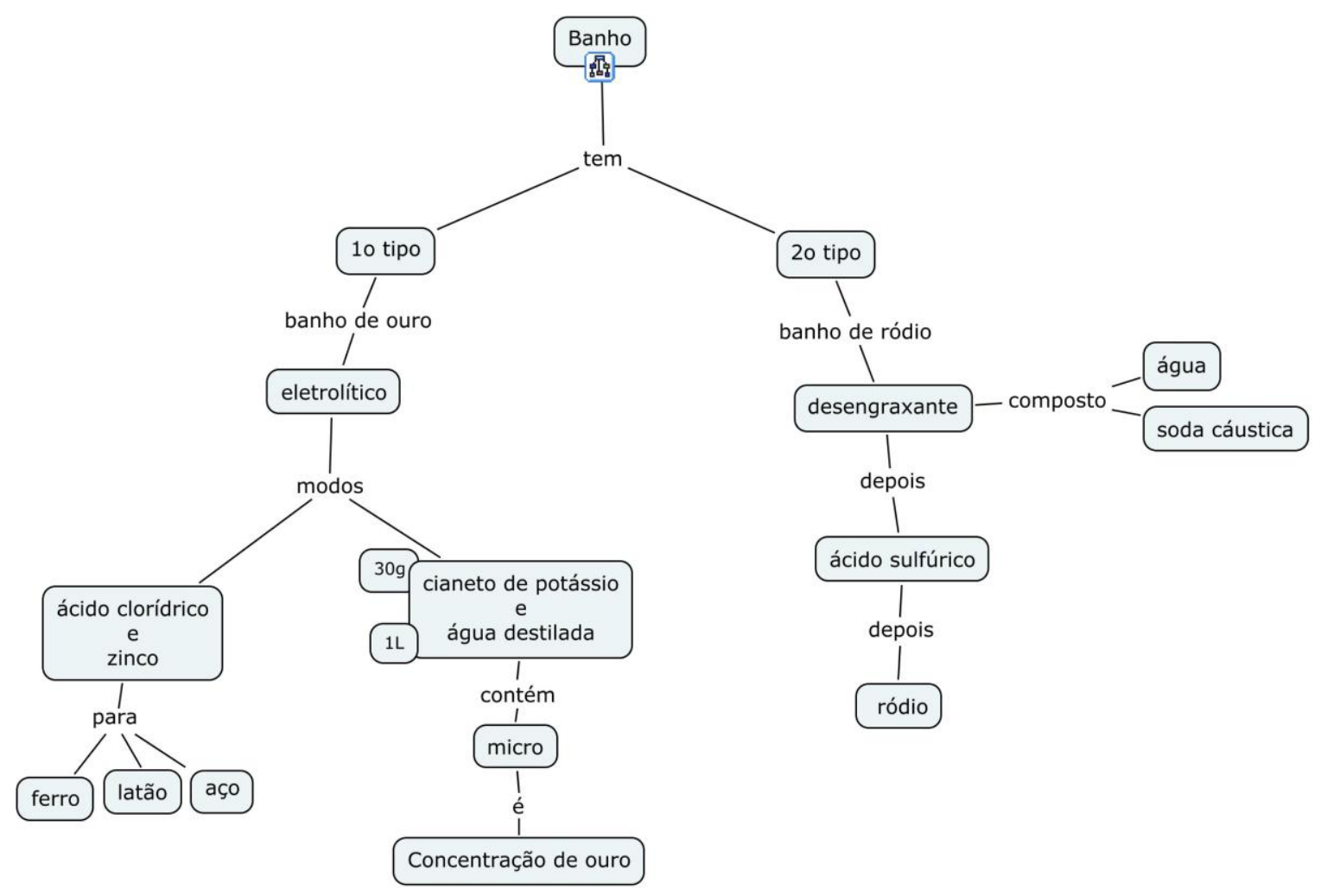

Figura 41. Célula extraída do mapa conceitual do ourives Álvaro.

\footnotetext{
${ }^{24}$ Água régia é uma mistura de ácido clorídrico e ácido nítrico, na proporção 1:3.
} 
William faz, ele próprio, o preparado (ácido clorídrico e zinco; cianeto de potássio e água destilada), mas Álvaro compra os banhos e somente os aplica. O ㄴo tipo de banho é realizado, ocasionalmente, por Álvaro, que tende na maioria das vezes, a terceirizar esse tipo de serviço.

Outro serviço muito requisitado compreende o processo de limpeza, que pode ser realizado de três modos, conforme mostra a Figura 42. O tipo a é realizado apenas por William, que utiliza o ultrassom. Esse tipo de limpeza é bom para peças com pedras que soltam a sujeira com a vibração. $O$ tipo b, em pregado por Álvaro, é feito por meio de um pequeno fogareiro com uma panelinha esmaltada e um pano envolvendo a peça que, quando é delicada, é muito sensível e apresenta detalhes que não podem atritar nem com a panelinha e nem com a escova. O tipo c é a forma que ambos os ourives utilizam para a limpeza de peças que não requerem muitos cuidados, isto é, não são tão delicadas. Esse modo é o mais simples e rápido.

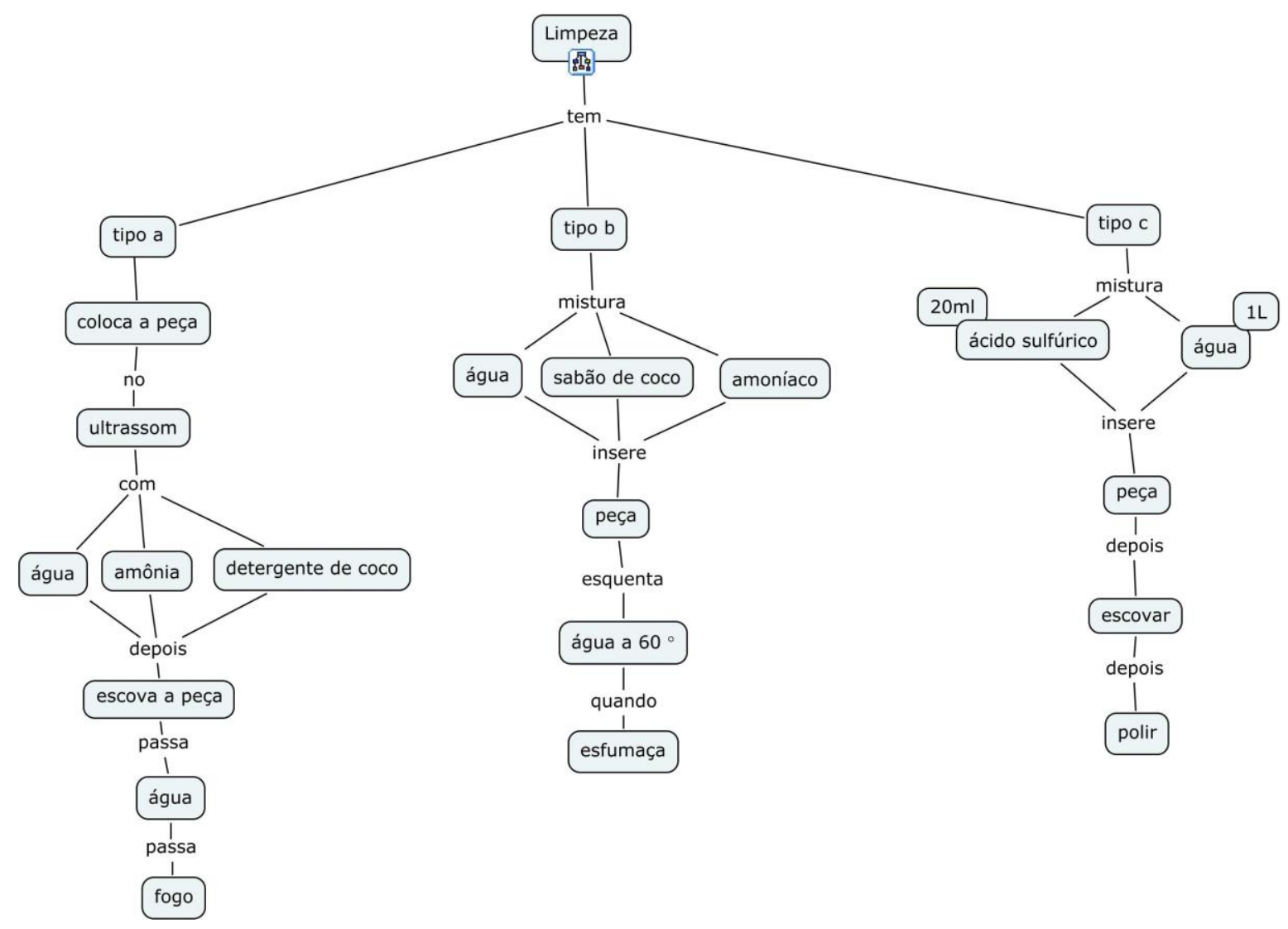

Figura 42. Célula extraída dos mapas conceituais dos ourives. 
A solda é outro serviço muito requisitado nas oficinas, que exige muita técnica e precisão, pois o intuito é que ela não seja perceptível aos olhos. Aparentemente, é algo simples, mas, antes de realizar a solda, o ourives deve verificar a liga da peça e o tipo do ouro. Quando uma peça está quebrada, o ourives tem o desafio de encontrar o ponto e a tonalidade certa para que a solda fique invisível. Para isso, a experiência da profissão, o conhecimento dos metais e do ponto de fusão de cada um é fundamental para que o serviço fique a contento (ver Figura 43).

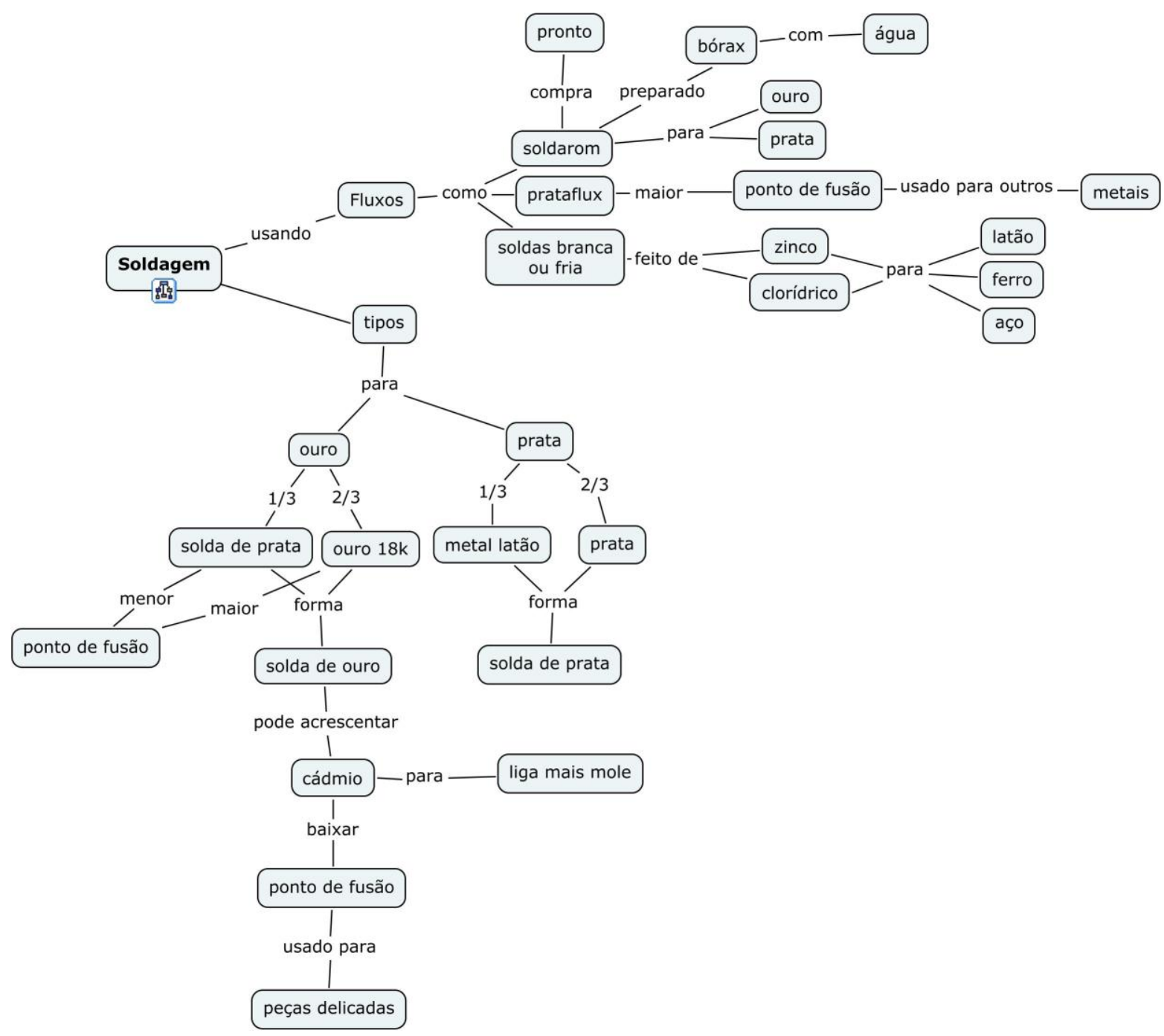

Figura 43. Célula extraída do mapa conceitual do ourives William. 
A solda de uma peça em ouro não pode ser com ouro porque ela derrete. São necessários pontos de fusão diferentes na solda de uma peça, seja ela em ouro, prata ou metal latão. No caso do ouro, é preciso que a solda tenha um ponto de fusão mais baixo que ele. Como diz William: o mesmo ouro não solda $\sigma$ mesmo ouro, derretem os dois juntos. Por isso, tem que ter uma mais fraca que a outra. Para ouro, utiliza-se solda de prata com ouro e para peças em prata, é usado solda de prata (prata com metal latão), conforme a Figura 51. O fluxo utilizado na soldagem é o soldaron para o ouro e a prata. Para os demais metais, usa-se o prataflux. Os fluxos auxiliam na soldagem, escorrendo a solda. A solda branca é usada para outros metais, como o latão, o ferro e o aço. O titânio não pega solda. Além disso, a quantidade de solda, a leveza e a rapidez dos movimentos interferem no resultado. Não foi percebida diferença no modo de realizar a soldagem entre os ourives.

Uma prática que tanto William como Álvaro realizam é a purificação do ouro, ou seja, levantar o seu grau. Para isso, é preciso enquartar, ou seja, selecionar quantidades de ouro e cobre para reagir com ácido, na proporção $1: 3$ (1g de ouro para $3 \mathrm{~g}$ de cobre). Álvaro mantém essa medida, mas o William descobriu que, utilizando $2 \mathrm{~g}$ de cobre, a eficiência é a mesma, ou seja, é suficiente para reagir com ácido.

[...] lamina no laminador, corta e põe no ácido nítríco de um dia para outro. Vai tirar o cobre todinho e vai ficar só o ouro. A quantidade de cobre faz o ácido reagir rápido, queima o cobre, ele vira fumaça e fíca só o ouro. (William)

Tem um processo que não faço na oficina, só faço em casa, a reação quimica é muito forte. A mistura de ácido nitrico com o muríático transforma o cobre em fumaca. Esse ácido é tão forte que víra [o ouro] liquido e fíca tão fino que fica imperceptivel para se ver a otho nu. Então, tem o processo de decantaçã, pra 
voltar o ouro a ficar sólido. Tem um processo mais simples que é com ácido nitrico, que pode ser feito na oficina. Vou fazer o processo mais simples. Vocês me acompanhem. Esse processo aqui é rápido. Tenho aqui um ouro baixo, um ouro que baixou. Não serve para trabalhar. Temos de trabalhar com a tabela mundial, que é o ouro 18 quilates. Se ele baixou para 14, tenho de purificar, não tem saida. Aqui, tem 8 gramas vezes 3; dá 24. Tería de colocar 24 gramas de cobre. Geralmente, se purifica [0 ouro] quando está quebrando. [Há] algum outro elemento que o ouro não aceita. Então, a gente costuma puríficar. (Álvaro)

As Figuras 44 a 54 mostram o processo de purificação do ouro.

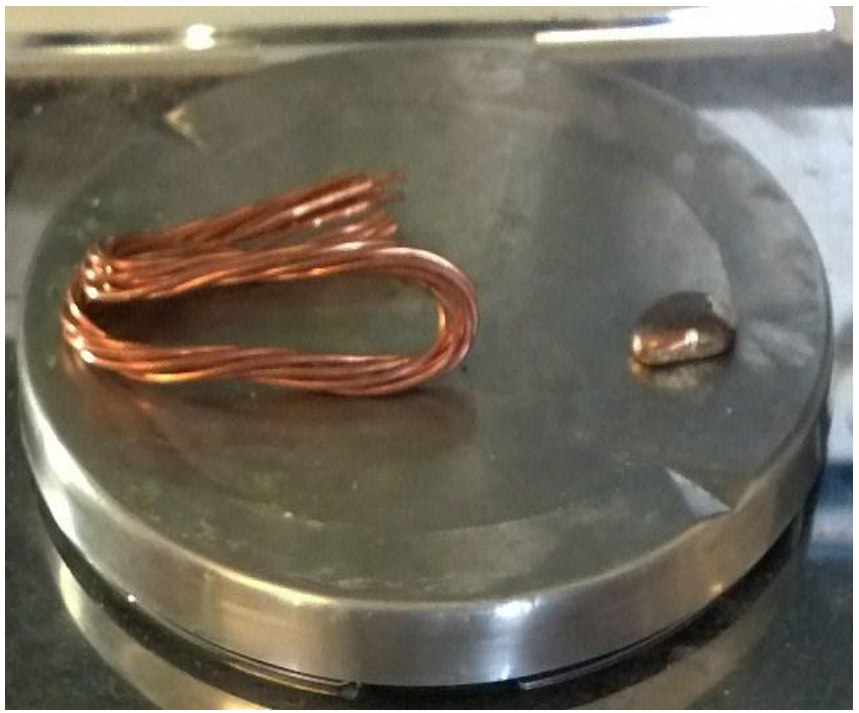

Figura 44. Cobre e ouro para enquartar. Fonte: fotografado em 25/07/2012 


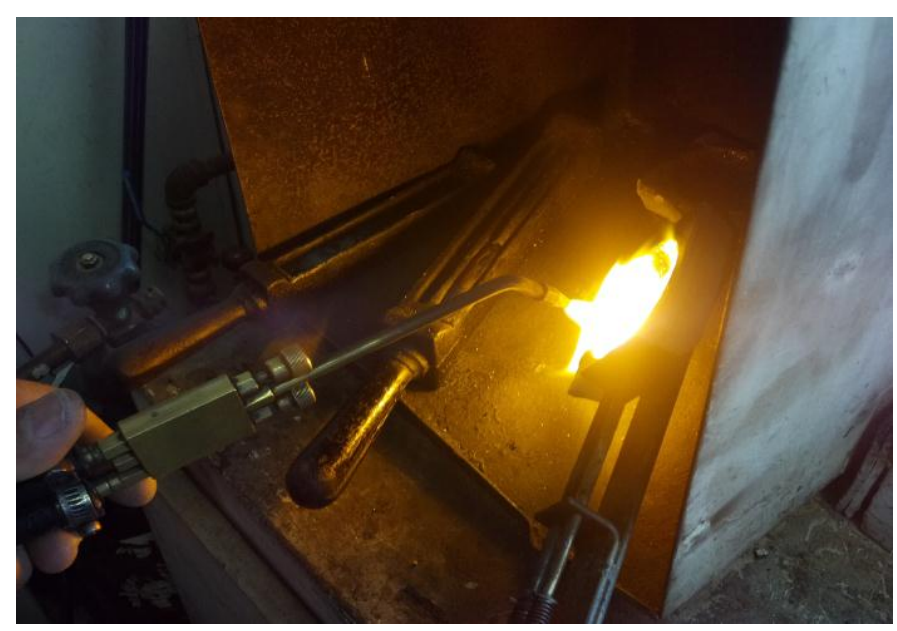

Figura 45: Fusão do ouro enquartado.

Fonte: fotografado em 25/07/2012

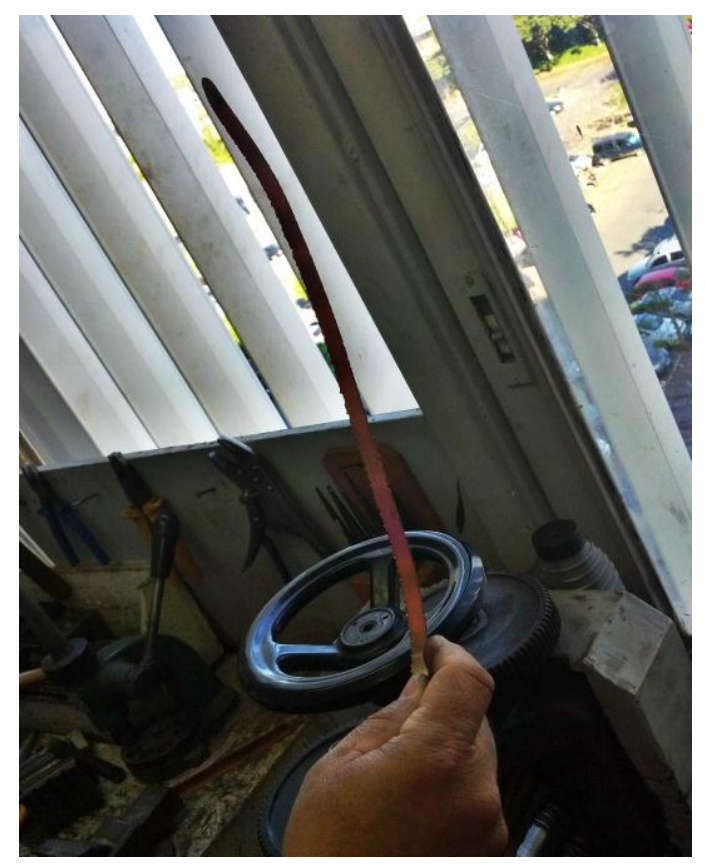

Figura 46. Ouro enquartado e laminado Fonte: fotografado em 25/07/2012 


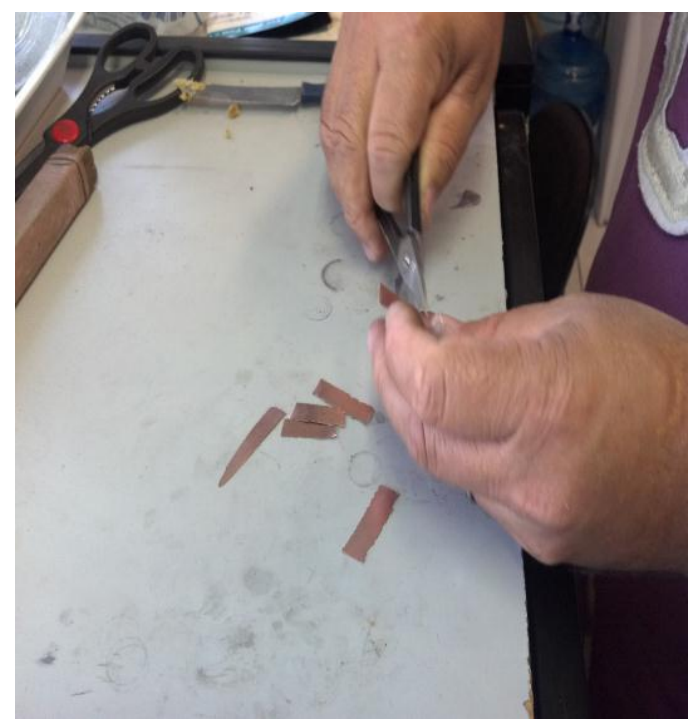

Figura 47. Picar o ouro laminado para reagir rápida com o ácido. Fonte: fotografado em 25/07/2012
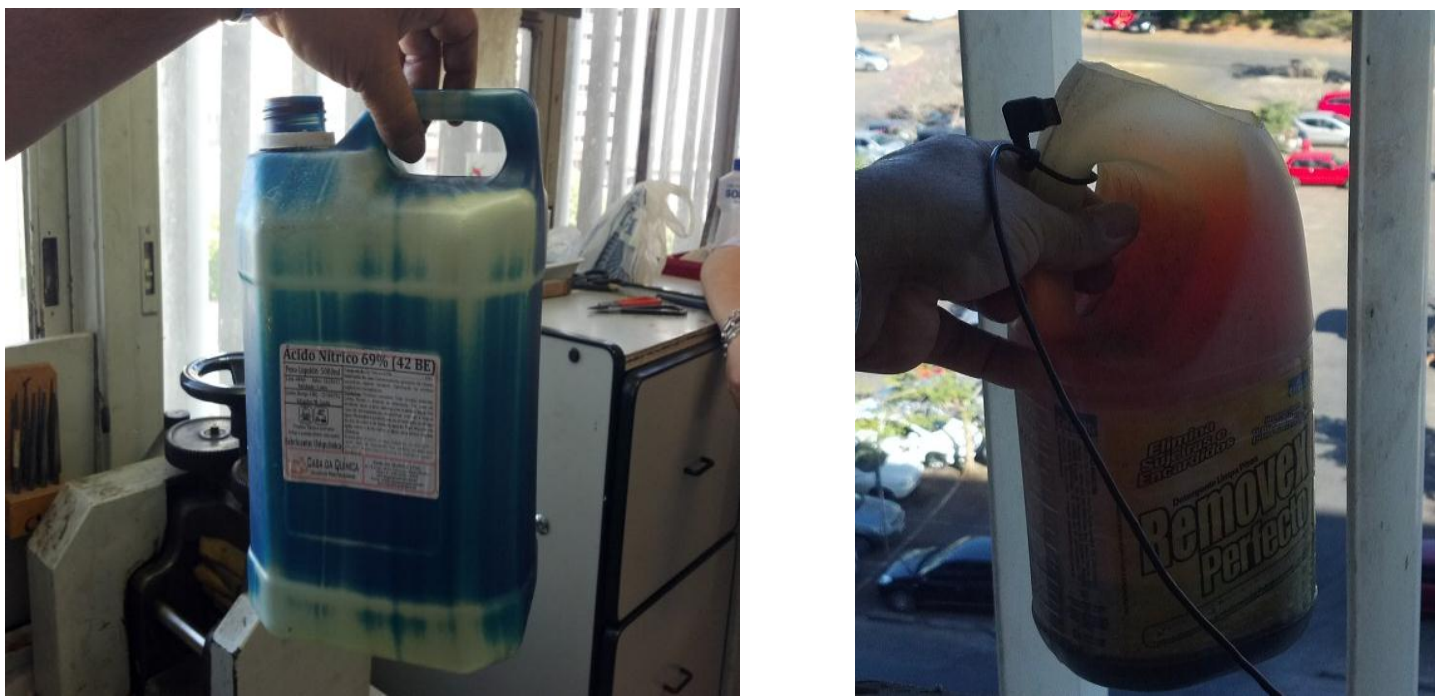

Figuras 48 e 49. O ácido nítrico é depositado em um recipiente juntamente com o ouro enquartado picado. A reação resulta em fumaça avermelhada com a liberação do cobre.

Fonte: fotografado em 25/07/2012 


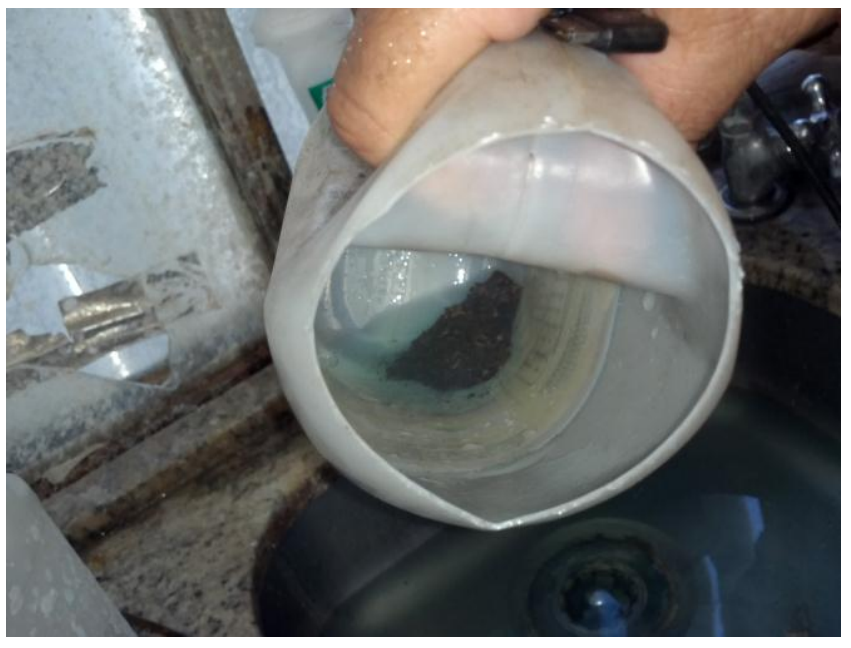

Figuras 50. Após 24h de reação, o ouro fica depositado no fundo do recipiente. Fonte: fotografado em 26/07/2012

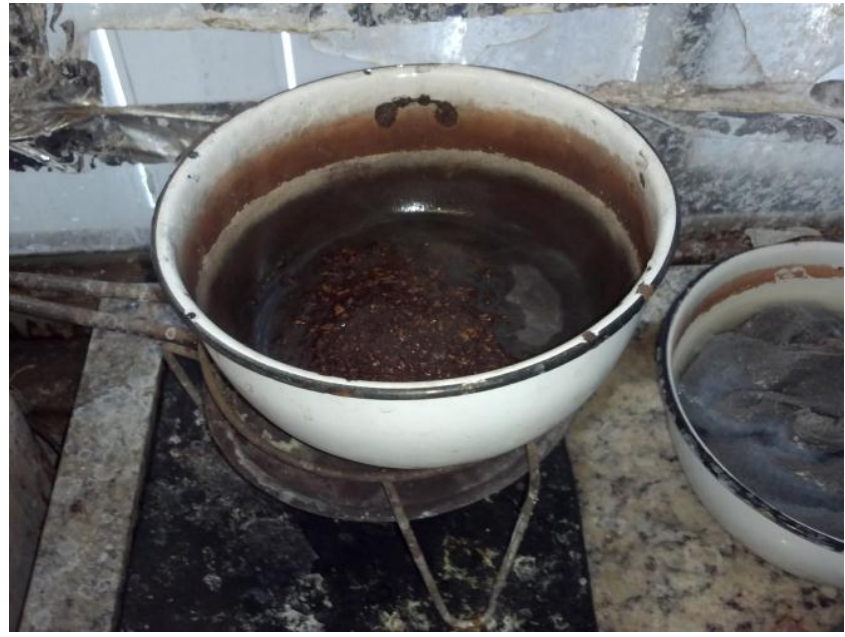

Figura 51. O ouro é colocado na panela esmaltada e aquecido para secagem.

Fonte: fotografado em 26/07/2012 


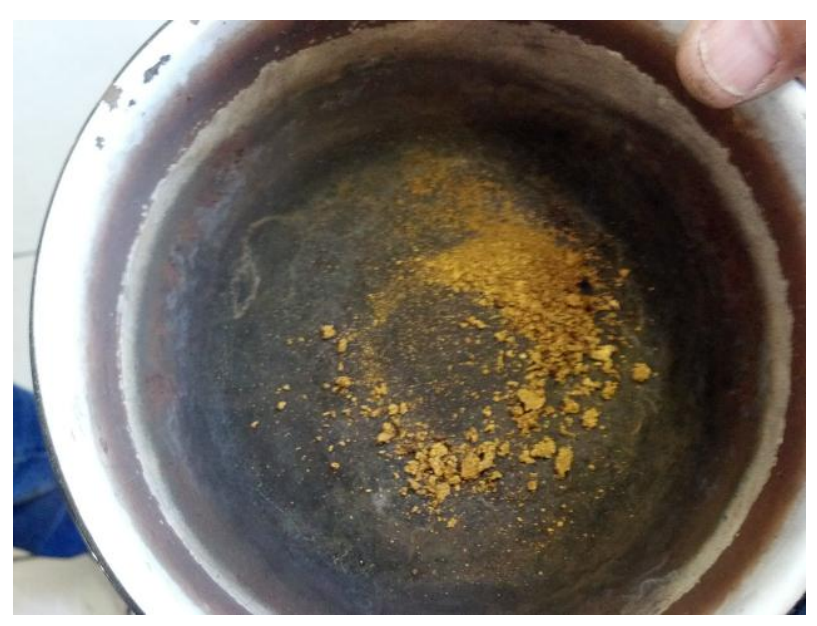

Figura 52. Ouro puro após secagem.

Fonte: fotografado em 26/07/2012

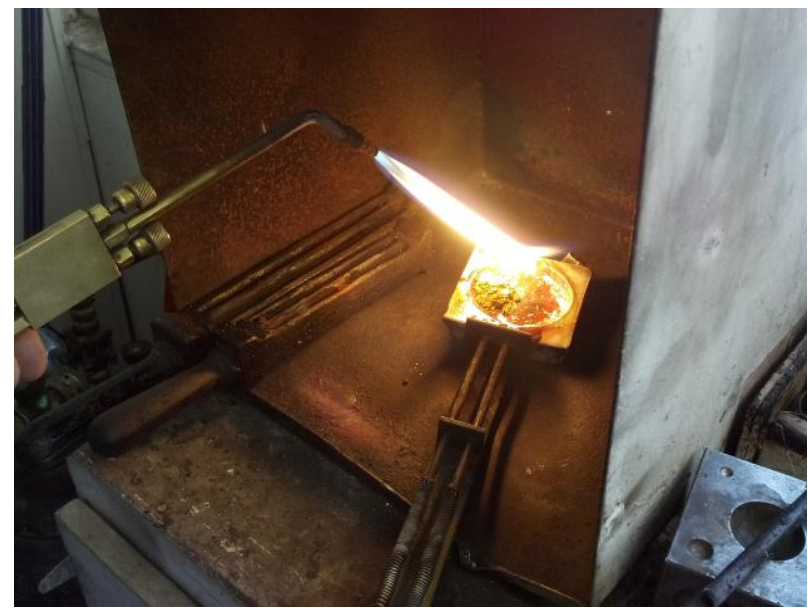

Figura 53. Antes de fundir o ouro, passa-se o bórax. Fonte: fotografado em 26/07/2012

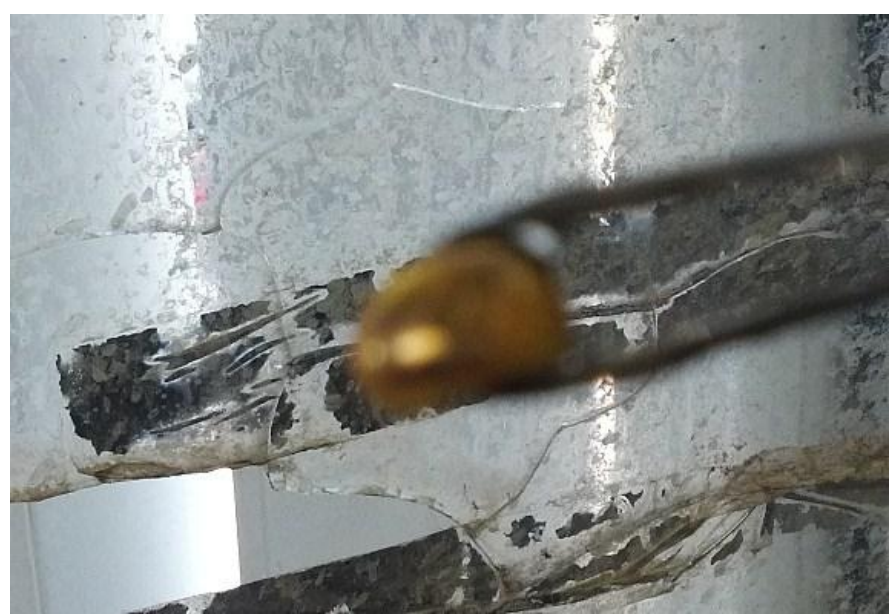

Figura 54. Ouro purificado.

Fonte: fotografado em 26/07/2012 


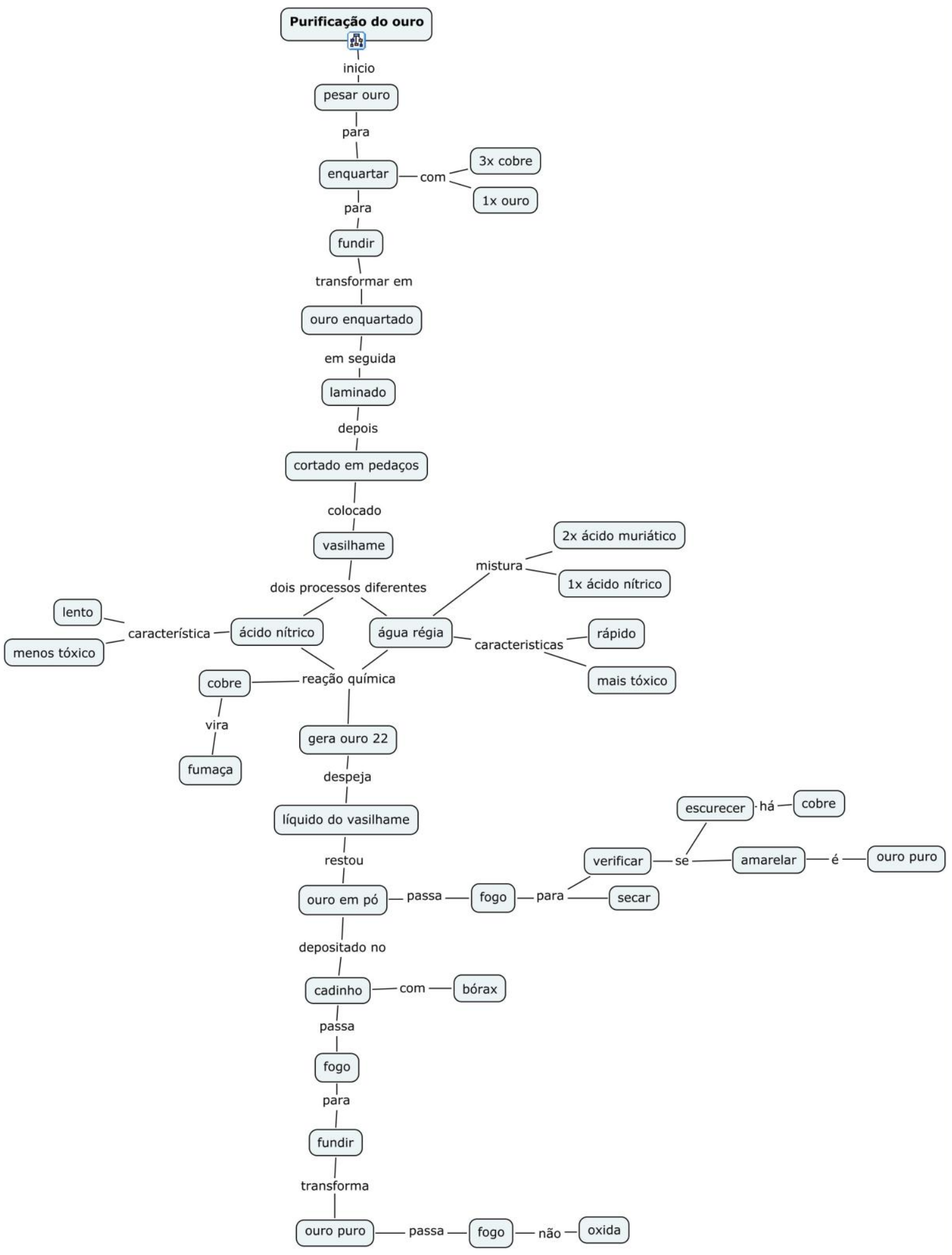

Figura 55. Célula extraída do mapa conceitual do ourives Álvaro. 
Quanto ao pensamento conceitual propriamente dito, procurou-se identificar, no mapa conceitual de cada ourives, os enlaces entre conceitos, estritamente falando. Assim procedendo, foram identificadas células de sistemas de organização conceitual com conceitos logicamente coordenados, subordinados e supraordenados, ainda que os atributos dos critérios para tanto sejam especificados pelo ourives em relação ao seu ofício e não em relação ao sistema teórico da ciência a que pertencem os conceitos.

Esse é o caso das células extraídas dos mapas conceituais dos ourives William e Álvaro, mostrados na Figura 56 e na 57, respectivamente. Na Figura 56, nota-se que há a especificação da prata, do ouro e do titânio como tipos de metais, sem que seja identificado o atributo de critério para tanto. Em seguida, o ourives particulariza o tipo de substância (prata, cobre ou paládio) ou material (latão), sem distingui-los, com que aqueles metais se ligam. Para isso, o que é levado em conta, como atributo de critério, é a propriedade observável resultante de sua mistura com outras substâncias (ouro, prata ou titânio), o que é importante para o ofício.

Ou seja, a pergunta Trata-se de um sistema conceitual? deve ser respondida afirmativamente, pois podem ser identificadas relações lógicas de coordenação e subordinação entre os conceitos. Todavia, a pergunta Trata-se de um sistema conceitual da ciência Química? deve ser respondida negativamente, embora o sistema contenha conceitos advindos desta ciência e sobre eles o ourives nada falou de incorreto. Por que ele não é um sistema conceitual científico? Porque, na especificação dos atributos de critério, ele não demonstra a pretensão da universalidade própria da ciência Química. Em síntese, é um sistema conceitual corretamente elaborado, que não contem erros do ponto de vista científico, mas que, se demonstrasse a pretensão da universalidade da Química, de nada serviria para a atividade de ourivesaria. 


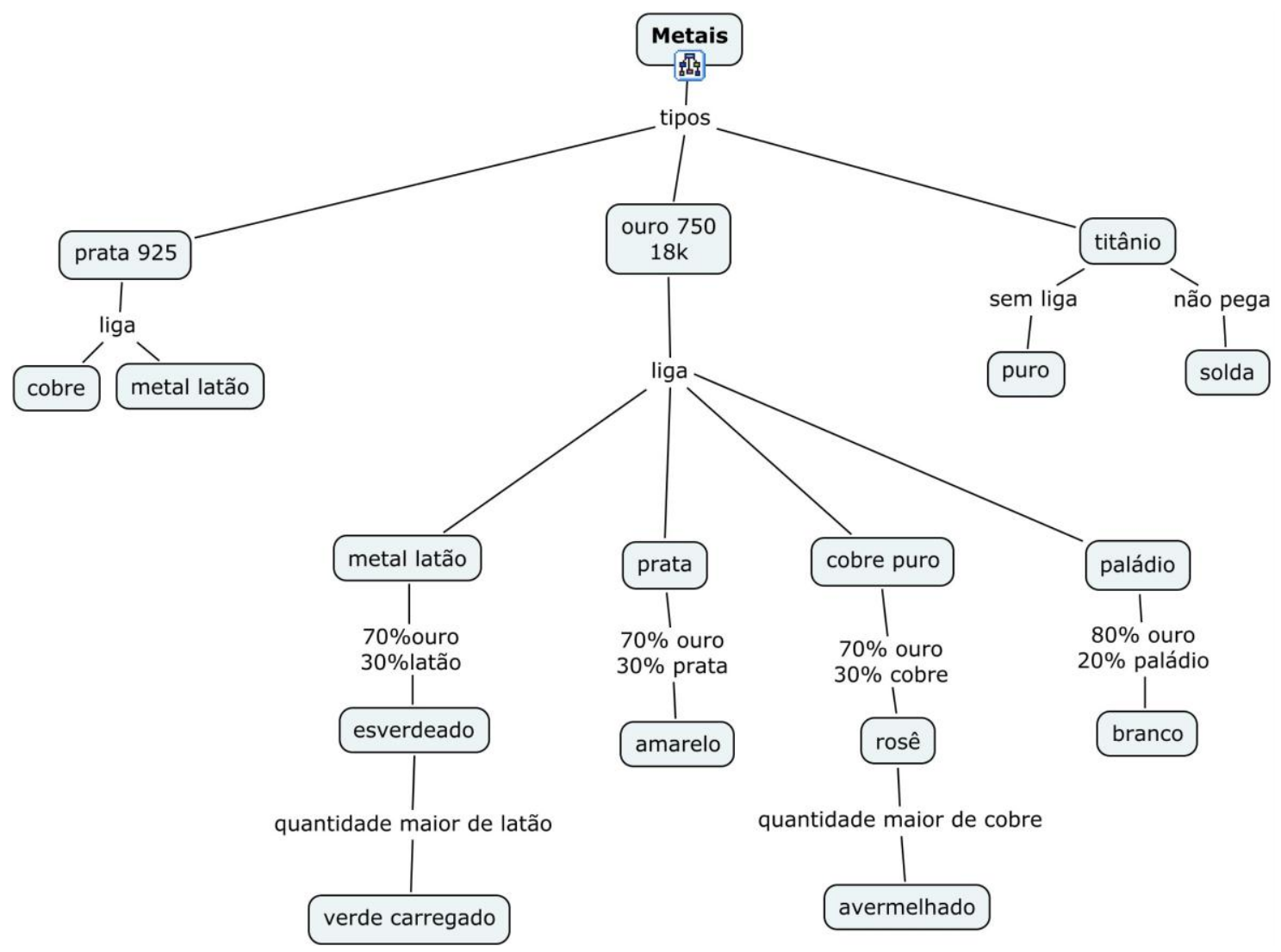

Figura 56. Célula extraída do mapa conceitual do ourives William para o conceito supraordenado de metais.

A Figura 57 é ilustrativa de outra célula de sistema conceitual, extraída do mapa do ourives Álvaro. Ela contém, no topo, o conceito de ácido a que se subordinam, imediatamente, alguns de seus tipos. Estes, por sua vez, são distinguidos pela função que têm no trabalho da ourivesaria. A diferença desta para a célula anteriormente mostrada encontra-se nesse terceiro nível de generalidade. Na primeira, o atributo do critério é uma propriedade diretamente observável, e não a função. Aplicam-se para essa célula da Figura 57 os mesmos comentários já feitos. 


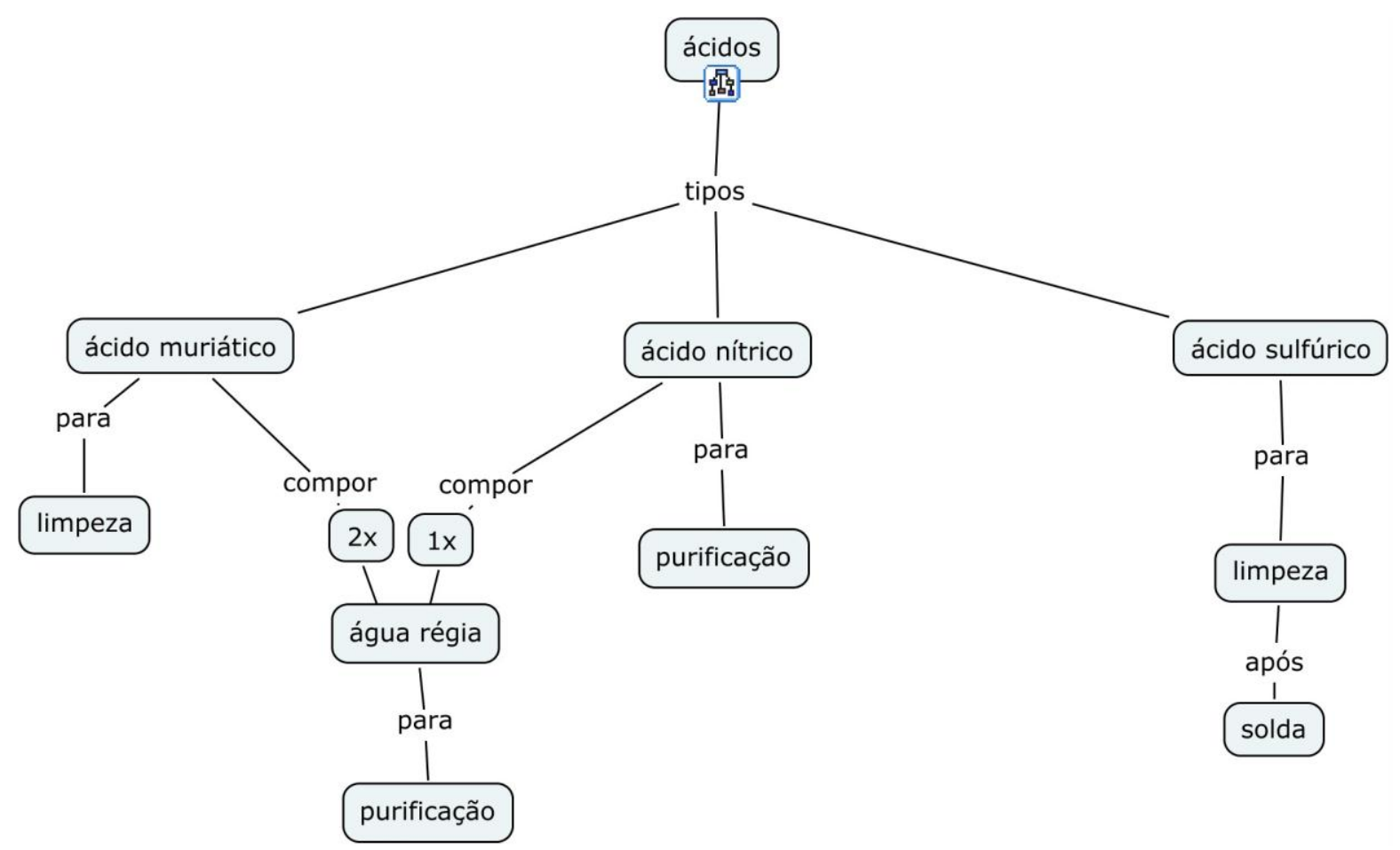

Figura 57. Célula extraída do mapa conceitual do ourives Álvaro para o conceito supraordenado de ácidos.

A atividade de ourivesaria - e, além dela, certamente, existem inúmeras outras - promove algo bastante similar ao que faz a escola, criando as condições de possibilidade para a emergência de um conhecimento híbrido, resultante do apoderamento do conhecimento científico e sua amalgamação com o que é proveniente da própria atividade de ourives. 


\section{O Ofício de Sineiro}

Como instrumento de som, o sino aparece em relatos no decorrer da história. Na Grécia, as campainhas eram utilizadas para eventos civis e religiosos. Há indícios de que o sino com sua forma atual tenha sido criado pelos frades. Ele aparece em relatos ligados à Igreja por volta do século $V$ d.C.. A Igreja utiliza esse instrumento para comunicação e alerta aos fiéis de algum perigo. Nas comunidades da Idade Média o sino era um importante instrumento de alerta para invasões e de perigo.

A fabricação de sinos é uma atividade artesanal, não escolarizada e aprendida com o mestre do ofício. É um ofício que atravessou os séculos, resistiu à revolução industrial e perdura até hoje, apesar dos avanços tecnológicos.

No Brasil, foram encontradas duas casas de fundição de sinos, a Angeli \& Ferreira, em São Paulo, e a Fundição Artística de Sinos Uberaba (FASU).

Para conhecer o ofício de fabricar sinos, foi contatado o fundador da FASU, Sr. José Donizete ${ }^{25}$, a quem se explicou o propósito da pesquisa e o interesse em conhecer o ofício in loco. Prontamente, o Sr. Donizete colocou-se à disposição e foi agendada uma primeira visita. Quando a pesquisadora chegou à FASU, gentilmente o Sr. Donizete mostrou o espaço físico e explanou sobre o processo de fabricação de sinos: etapas, materiais utilizados, ferramentas e locais onde acontece cada etapa do processo. Em duas entrevistas relatou sua história de vida e como aprendeu o ofício, como ele diz: a arte de fazer sino.

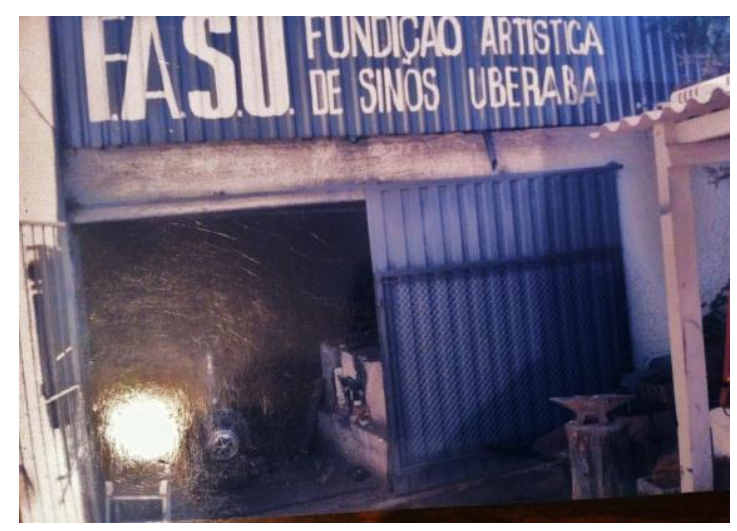

Figura 58. Fachada da Fundição Artística de Sinos Uberaba/FASU. Fonte: foto cedida pelo Sr. Donizete do acervo da FASU

\footnotetext{
${ }^{25}$ Com o intuito de divulgar o trabalho que realiza, o Sr. Donizete autorizou que seu nome fosse mantido.
} 


\section{O Sr. José Donizete e seu Mestre: breve relato histórico}

Aos doze anos de idade, José Donizete prestou exame para a Escola da Força Aérea de Pirassununga, onde permaneceu por um ano e oito meses e, posteriormente, foi à escola de Guaratinguetá. Como recebia uma ajuda de custo pequena e necessitava de dinheiro para mandar para casa, procurou trabalho na fundição de sino do Sr. Giácomo Crespi. Aos treze anos, frequentava a escola da Força Aérea e trabalhava na fundição. Com catorze, desistiu da Força Aérea e dedicou-se ao ofício de sineiro e a ajudar o mestre Giácomo. Lá, permaneceu por dezessete anos; trabalhou e aprendeu a respeito da técnica medieval de fabricação de sinos, conforme relatou.

Dom Evaristo Arns, na época Arcebispo de São Paulo, prontificou-se a recolher documentos que reconheceriam sua prática como a da técnica medieval. Para isso, encaminhou para a Itália os documentos com a descrição dos modos de proceder do Sr. Donizete. Em Roma, foi pesquisada a história da técnica medieval, seus documentos foram aprovados e o seu conhecimento sobre fundição de sinos foi reconhecido. O Sr. Donizete recebeu do Vaticano um documento que o certifica como sineiro. Conforme informou, o Sr. Crespi foi um segundo pai, o pai da profissão.

Segundo informou o Sr. Donizete, tudo o que aprendeu foi observando o velho mestre em seu ofício. Este desejava que um de seus netos continuasse seu trabalho e fosse seu herdeiro de sua profissão. Mas nos últimos anos de vida, dedicou-se mais ao $\mathrm{Sr}$. Donizete e afirmava que este iria dar continuidade ao trabalho. A convivência do Sr. Donizete com o Sr. Crespi foi de onze anos, de 1969 a 1980. Em 1980 este veio a falecer e, em 1982 e parte de 1983, o Sr. Donizete deu continuidade aos serviços contratados.

Retornando a Uberaba/MG em 1983, o Sr. Donizete organizou a sua casa de fundição e ia a São Paulo, esporadicamente, para conclusão de compromissos assumidos pela família Crespi.

Giácomo Crespi, italiano de Crema, seguiu a tradição familiar de fabricar sinos por toda sua vida. Veio para o Brasil na década de 1950, após ter participado 
das duas Grandes Guerras. Na Primeira, participou porque fora obrigado pelo pai e, na Segunda, porque fundia canhões a partir dos sinos derretidos. Durante a $2^{\underline{a}}$ Guerra, foi professor de fundição, chegando a fundir urnas funerárias. Ao chegar ao Brasil, escolheu o Estado de São Paulo para fincar raízes. O site da família Crespi apresenta um pouco da história, como segue abaixo.

A Fundição Crespi foi fundada em 1498, anterior à descoberta do Brasil, 7 vezes premiada com medalhas de ouro em exposições internacionais, fornecedora da cidade do Vaticano e do governo italiano. A caminhada dos Crespi, suas realizações e documentos autênticos são comprovados desde 1498, em Crema - Itália, em dois livros escritos e editados na Itália, pelo Exmo. e Revmo. Dom Gino Cavaletti, no ano de 1985. Roberto Crespi Marenco, neto e sucessor do grande mestre e artífice, Giácomo Crespi, acredita que os Crespi tenham mais de 1000 anos, devido às histórias que seus antepassados contavam. Roberto não consegue mais definir quantos sinos foram fabricados pela Fundição Crespi, pois desde a época das grandes navegações, já se ouviam (sic) o som dos sinos por eles fabricados. Pelo mundo a fora, ( $\mathrm{sic}$ ) ouvem-se os sinos fabricados pelos Crespi, principalmente, na Europa, Estados Unidos, África, lugoslávia, Egito (no Cairo) e América do Sul. Um fato curioso está registrado em crônicas do século XVIII. Conta-se que Napoleão Bonaparte ao passar pela praça II Duomo, na cidade italiana de Crema, mandou parar sua carruagem somente para ouvir o som melodioso dos sinos, de fabricação Crespi, que tocavam. Naquele tempo Domenico Crespi foi considerado um gênio por ter inventado o Relógio Monástico, que possuía no disco central, aspectos astrológicos e as fases lunares, em 1750 e, também por ter criado no mesmo ano, as escalas musicais para os sinos. Giácomo Crespi, que nasceu em 21 de maio de 1887 em Milão/Itália, participou das duas grandes Guerras Mundiais. Veio para o Brasil em 1959, e só parou de fabricar sinos quando faleceu no dia 26 de julho de 1980. O grande mestre dos sinos recebeu como homenagem e reconhecimento à sua nobre arte, uma Rua na Vila Mirante/Pirituba. (Disponível em: <HTTP://www.sinoscrespi.com.br/casos.html>. Acesso em: 12 jul.2012. 


\section{A atividade do Sineiro}

Toda narrativa feita a seguir está baseada nas informações prestadas pelo Sr. Donizete. Segundo ele, o processo de fabricação de um sino contém as etapas mostradas na Figura 59:

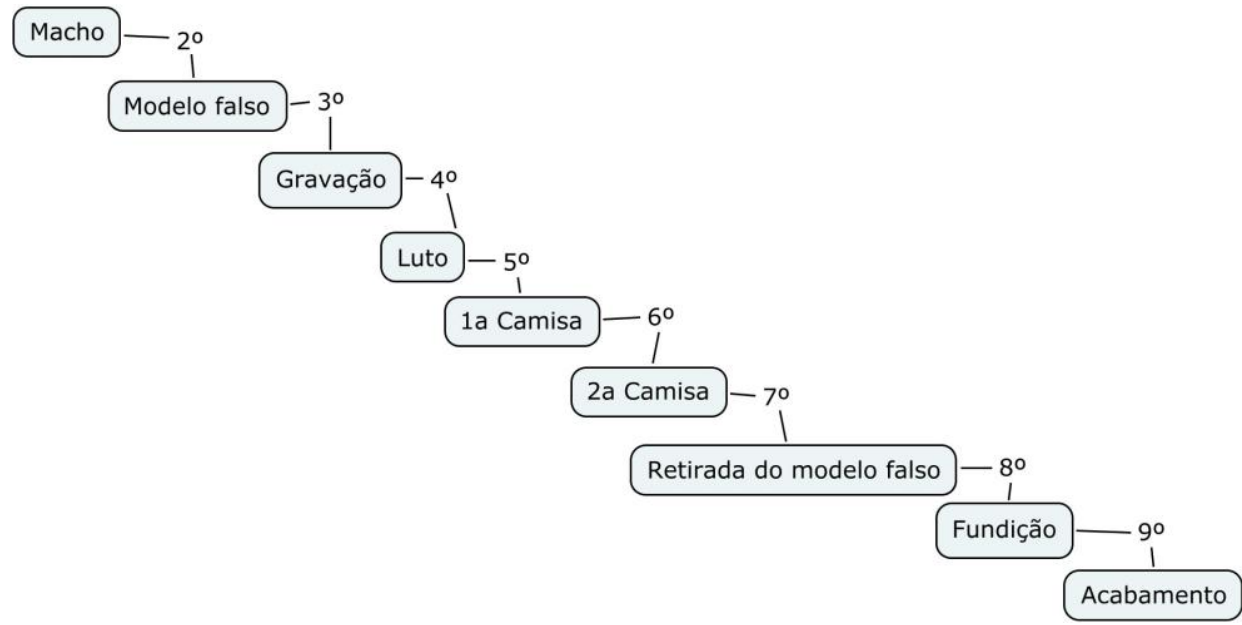

Figura 59. Sequência das principais etapas.

o processo de fabrícação do sino leva 30 dias, conforme relatou. Para começar a fabricação, constrói-se com tijolos e argila a parte de dentro do chamado "perfil", que é montado sobre uma base de tijolos já em forma de braseiro, conforme mostra a Figura 60. Esses tijolos são provenientes de casarões velhos e comprados de demolições. No centro da base de tijolos, é fixado um mastro de ferro com marcações de possíveis tamanhos, que corresponde ao ponto central da circunferência da boca do futuro sino (ver Figura 61). 


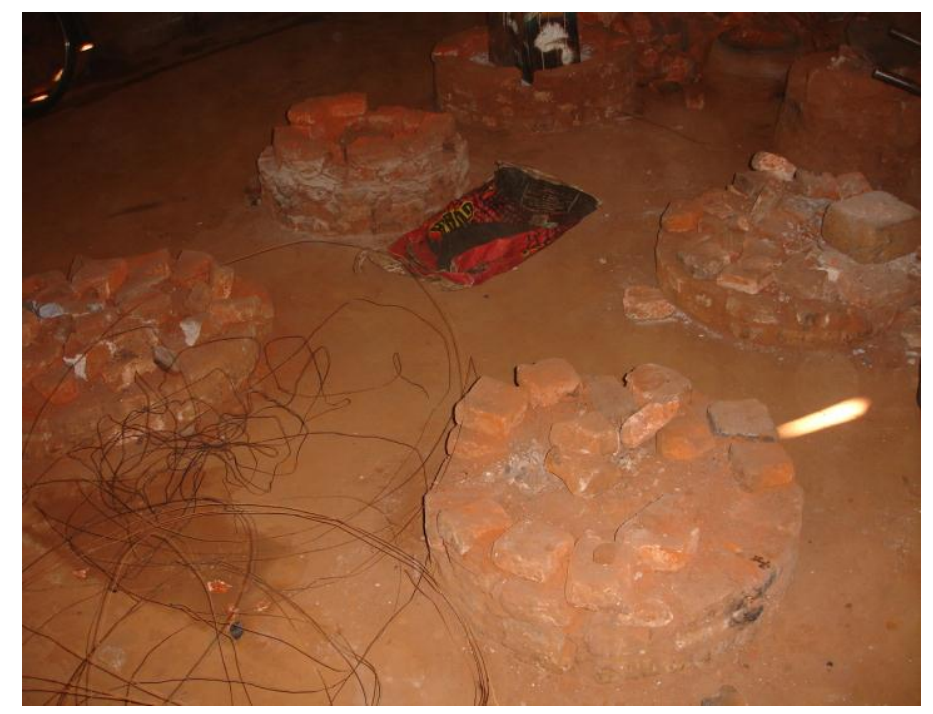

Figuras 60. Bases para os braseiros .

Fonte: fotografado na visita de 20/07/2012

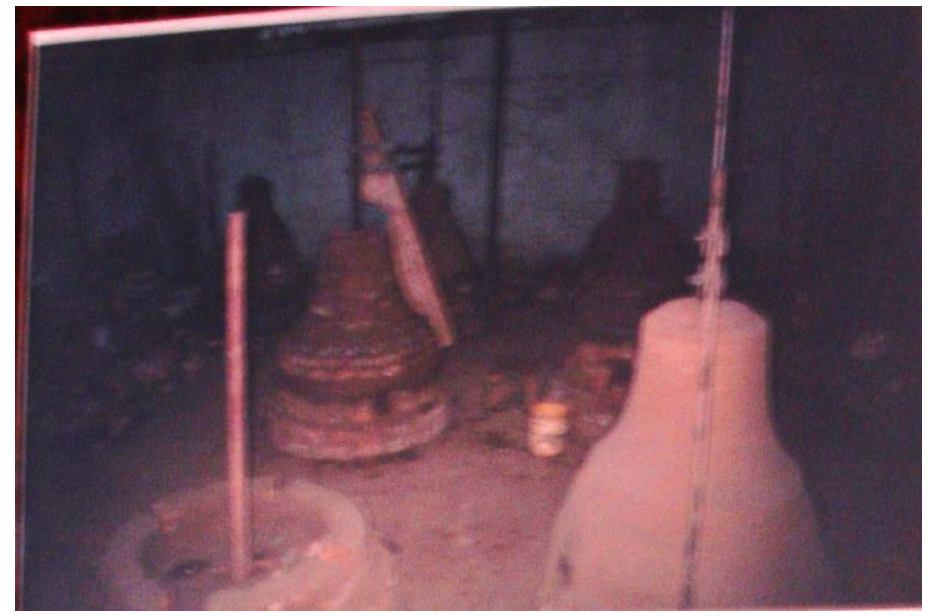

Figuras 61. Mastro fixado, etapa inicial de fabricação de sinos. Fonte: cedida do acervo da FASU

Para dar a forma ao sino, conforme o tamanho e peso desejado, utiliza-se uma ferramenta de madeira, que indica o traçado do desenho do sino, denominada chapelona, conforme mostra a Figura 62. Essa ferramenta foi criada pelo mestre Sr. Crespi, com base em cálculos matemáticos que indicam as medidas da parte interna e externa do perfil, e é chamada pelo Sr. Donizete de macho. 


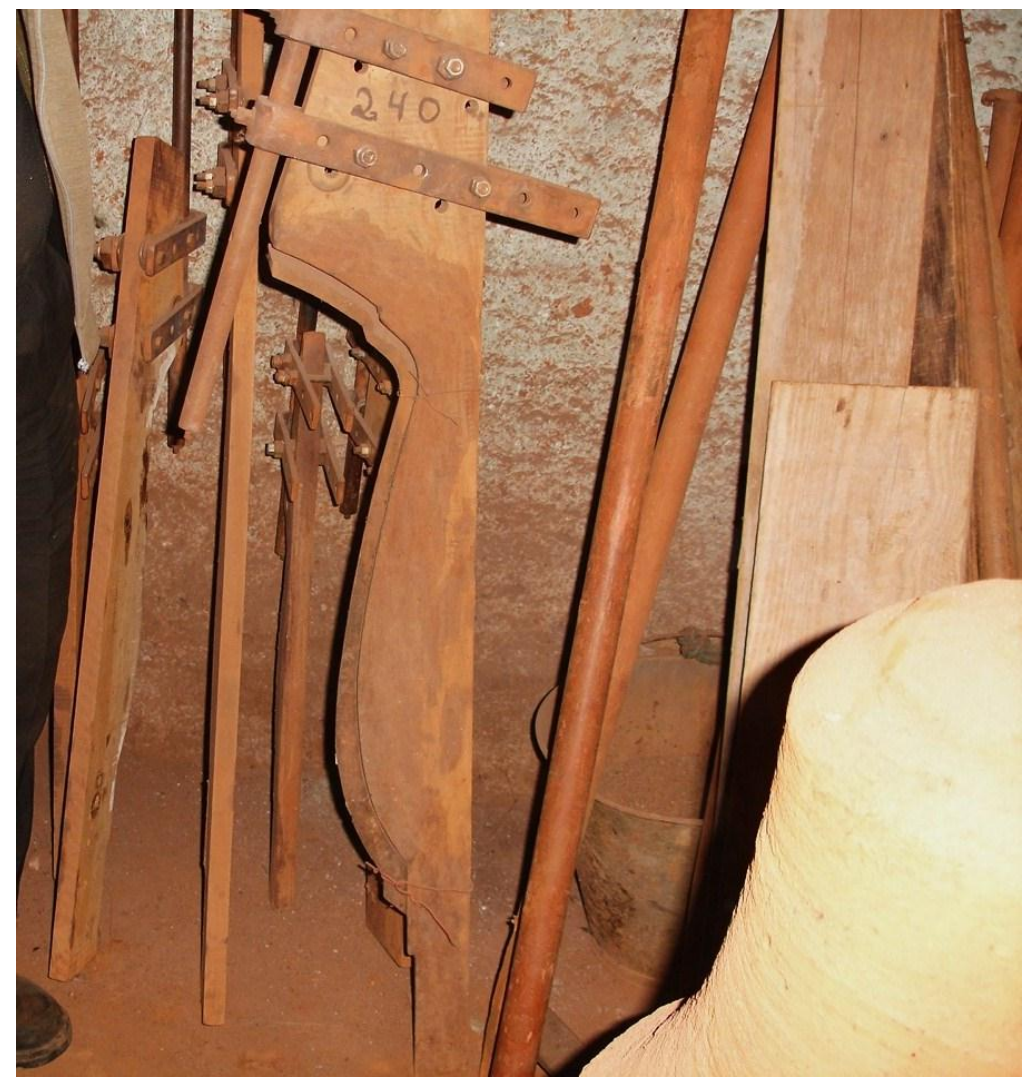

Figura 62. Chapelona, linha externa e interna - diferentes tamanhos. Fonte: fotografado na visita realizada em 20/07/2012

A linha de desenho interno da chapelona dá a forma interna do perfil e a linha maior dá o desenho externo. Há uma chapelona para cada tamanho e peso de sino. O diâmetro da boca do sino, sendo igual à altura e o peso [relação entre essas medidas], dá a nota musical. Cada sino tem a sua respectiva nota musical com sua medida e desenho. Se o desenho for muito grosso ou muito grande influi na nota musical. Essa relação é mostrada na Tabela 1.

$\mathrm{Na}$ construção da parte de dentro do perfil, são utilizados tijolos com argila fabricada pelo Sr. Donizete, um refratário natural, sem produto quimico [industrializado] e não prejudicial à saude. A argila é refratáría porque consegue ter tolerância ao calor, fogo, porque, se ela não for refratária, na hora que for jogar o metal derretido a 1100 graus, ele [0 perfil do futuro sino] desmancha, desfaz. 
Tabela 1. Relação entre notas musicais, diâmetro e peso do sino

\begin{tabular}{|c|c|c|}
\hline NOTAS & DIÄMETRO EM m & PESO APR. kg \\
\hline LA bemol & 1.810 & 3.300 \\
\hline LA & 1.710 & 2.800 \\
\hline SI bemol & 1.605 & 2.360 \\
\hline SI & 1.515 & 1.950 \\
\hline $\mathrm{DO}$ & 1.435 & 1.650 \\
\hline RE bemol & 1.342 & 1.370 \\
\hline RE & 1.265 & 1.140 \\
\hline MI bemol & 1.200 & 970 \\
\hline MI & 1.132 & 800 \\
\hline FA & 1.070 & 680 \\
\hline SOL bemol & 1.010 & 575 \\
\hline SOL & 0.953 & 485 \\
\hline LA bemol & 0.905 & 410 \\
\hline LA & 0.850 & 340 \\
\hline SI bemol & 0.800 & 295 \\
\hline SI & 0.755 & 240 \\
\hline DO & 0.715 & 205 \\
\hline RE bemol & 0.670 & 170 \\
\hline RE & 0.632 & 140 \\
\hline MI bemol & 0.600 & 120 \\
\hline MI & 0.566 & 100 \\
\hline FA & 0.535 & 85 \\
\hline SOL bemol & 0.505 & 72 \\
\hline SOL & 0.476 & 60 \\
\hline LA bemol & 0.452 & 50 \\
\hline LA & 0.425 & 43 \\
\hline SI bemol & 0.400 & 37 \\
\hline SI & 0.377 & 31 \\
\hline $\mathrm{DO}$ & 0.357 & 27 \\
\hline RE bemol & 0.335 & 22 \\
\hline
\end{tabular}

A argila fabricada é composta de terra vermelha com caracteristicas de massapé e esterco de cavalo. 60\% de terra vermelha massapé, que é grudenta e pegajosa, permite uma boa modelagem e $40 \%$ de esterco dão a liga. Outra possibitidade é a terra preta do brejo com o esterco seco. Quando a terra é mothada, usa-se o esterco seco; quando a terra é seca, usa-se o esterco mothado, na mesma proporcão. $\mathcal{O}$ esterco de cabrito não serve porque é extremamente seco; nem na máquina ele desmancha. Perguntado a respeito da terra vermelha, o Sr. Donizete esclareceu: 
Nem toda terra vermelha presta. Tem uma que é chamada de sangue de boi. Aquela, apesar de ser vermelha, ela possui pra mais de 30\% de areia; não presta porque ela vai dar muita resistência ao calor e a modelar; porque ela se desfaz muito por causa da areia, nés! Encontra em aterro; escavação sempre sai essa terra aqui, quase no Brasit inteiro encontra... a gente tem que saber, tem uma vermelha no Paraná, lado de Londrina, que se estende até Foz do Iguacu e Paraguai. É a mesma terra. É terra vermelha que não é massapé. Ela tem areia demais. Quando a gente vaí fazer un servico, a primeira coisa que eu fico de otho é o que pode me ajudar. Igual região que faz muita olaria, faz muito tyjolo ow telha, pra mim me serve, porque eu otho se consigo lá argita natural, que é argita do subsolo, do poço ... fura-se um poço muito fundo ai, uns 12 e 13 metros de profundidade, conforme a região já sai uma liga, uma lama, uma lama dura que serve pra fazer telha, pra fazer tyolo, e pra mim serve pra eu fazer meus moldes, porque ela resiste sem en precisar colocar qualquer outro ingrediente, inclusive a fíbra, não preciso colocar a fíbra. Ela seca normal, porém com pouco fogo, ela seca sem trincar. A gente pode também utitizar aquela terra que já foi queimada pelo clima, não queimada por fogo; às vezes acontece uma queimada e tudo, mas aquito vai tudo embora, com chuva leva tudo embora. Aquele residuo que fica nas encostas, no pico de uma serra, então, escorre água, escorre sujeira, lama, escorre e vaí juntando tudo ati em volta. Aquela terra, atém de ser boa para jardinagem, pra hortalica, ela é boa pro meu servicso também. Ela só desceu residuo. Aquele residuo vaí reciclando no caminho. Aquele que vai compor, vai misturar, vai botar orgânico na terra, 
é que é o natural pra mim bater, pra fazer minha lama, mew barro. Outra alternativa é a terra preta do brejo com o mesmo esterco, porém tem que usar um esterco seco. Quando a terra é lama, en uso esterco seco; quando ela é seca, uso o esterco mothado. Tem que jogar água nele, quebrar ele, pra facititar a mistura, a liga. A proporção é a mesma e o esterco é o mesmo, nunca que muda.

Ao ser perguntado a respeito do esterco de boi e de vaca, o Sr. Donizete respondeu que esses animais remoem mais o capim que o cavalo; por isso, o esterco deles não serve para o fabrico de sinos. Ele alerta para o fato de que o esterco do cavalo que come ração não serve para a fabricação da argila, pois o apropriado é o do cavalo que se alimenta somente de capim. Do contrário será preciso usar a ureia, que substitui o capim.

A vaca é ruminante, não serve. $\mathcal{O}$ cavalo é só capúm. Já me ofereceram o esterco da poticia. Esse não adianta, eles come ração. $O$ cavalo come ração, come mitho, não serve; tem que ser palha, bucha, tem que ser o capim. Tem que ser do cavalo que come capim. Esses cavalos que come alfafa não presta. Pra en fazer $\sigma$ sino sem o esterco, tenho que usar a ureia; ela substitui o capim. Agora, en utitizo o capúm porque é mais fácíl, é mais prático, pra mim é mais barato e não tem química [produto industrial] Porque a ureia, conforme misturar nela, você tem que trabalhar com luva.

Para misturar esses componentes, ele criou uma máquina, do tipo de uma betoneira (ver Figura 63) cujas paletas batem e sovam a massa de argila com água, 
porque seco, a máquina não tem jeito de funcionar porque ela embucha, empasta muito, endurece.

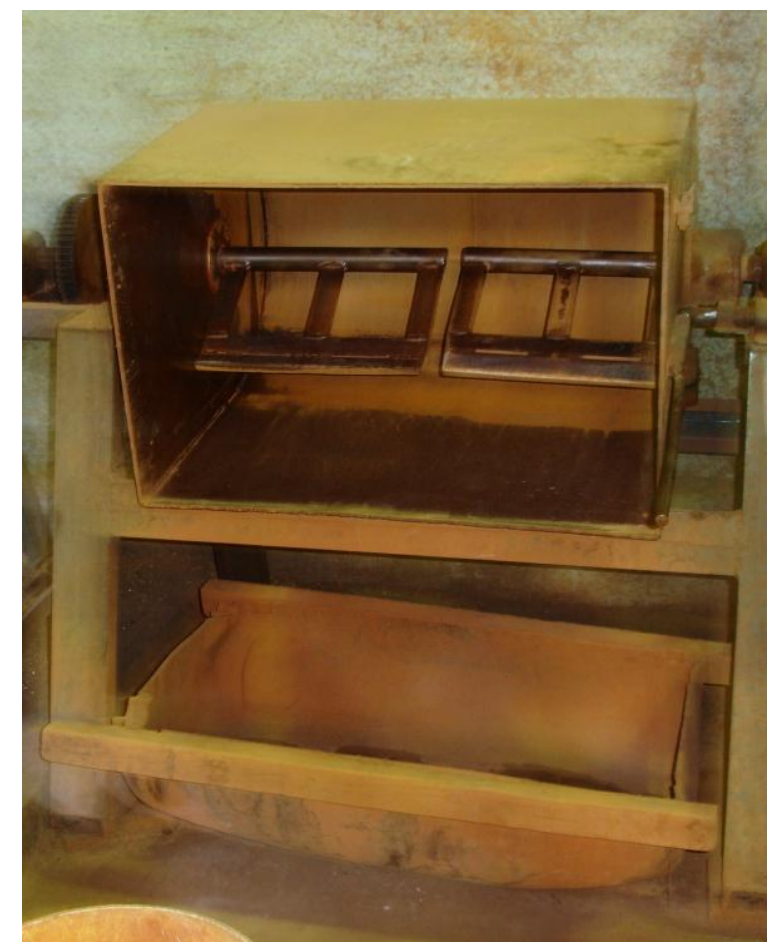

Figura 63. Betoneira.

Fonte: fotografado na visita realizada em 20/07/2012

Seguindo o desenho, ao riscado da chapelona, juntamente com os tijolos e a argila fabricada, é acrescida uma trama com arames que dão a sustentabitidade, sustentação da pressão, porque se fizer só de barro, quando colocar dentro do buraco pra prensar, não aguenta. Depois de pronto, passa, também, uma camada desse araminho para ajustar mesmo a trama com o tyolo e tudo para quando estiver com alta pressão não deformar porque, se não fizer isso, ele deforma, ditata muito, conforme mostra a Figura 64. 


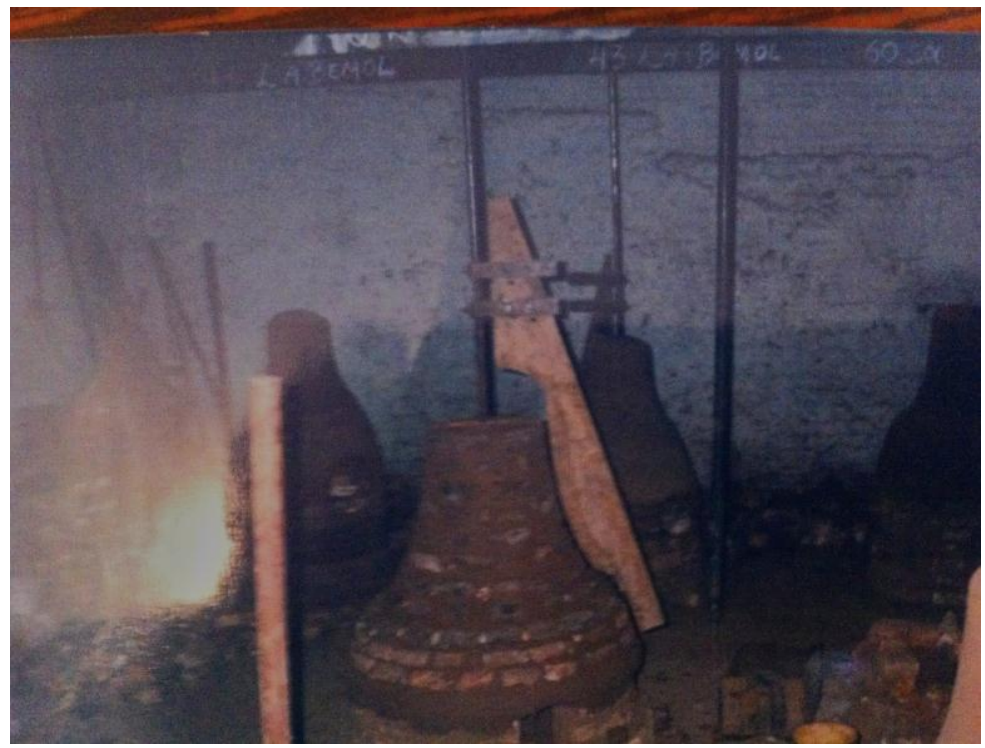

Figura 64: Estágio inicial da fabricação, levantamento da forma de tijolos amarrada com arames. Fonte: fotografia do acervo da FASU

Finalizada a etapa de construção da parte de dentro do perfil, o mastro é retirado e inicia-se o aquecimento sobre o braseiro para secagem. No braseiro, é utilizado o carvão vegetal. Para secagem do macho, é preciso cerca de quatro dias sobre o fogo do braseiro (ver Figura 65).

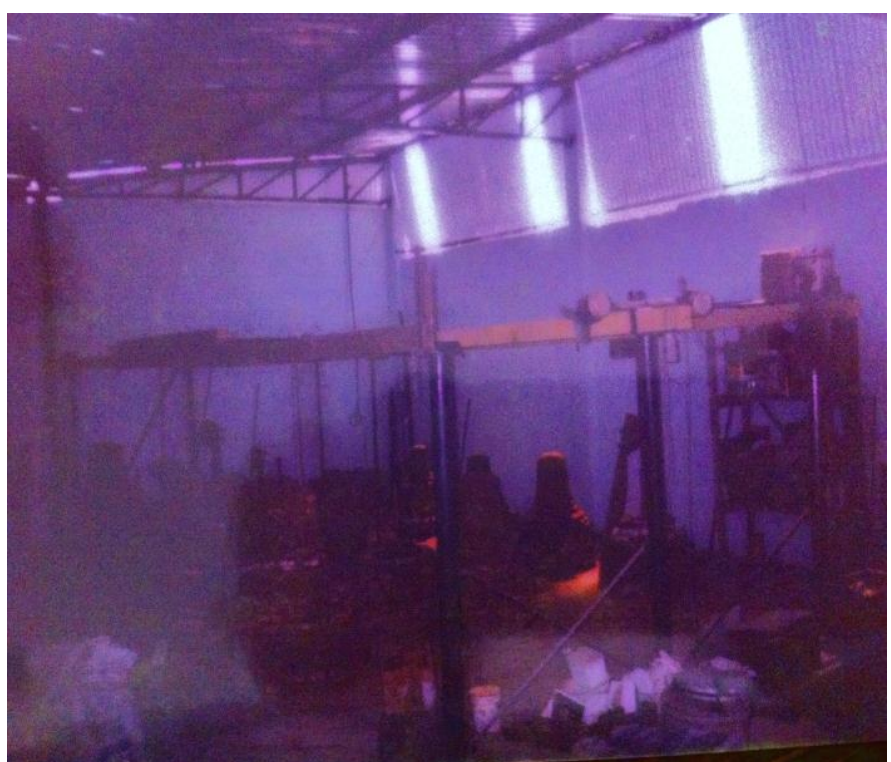

Figura 65. Formas prontas sendo aquecidas no braseiro. Fonte: fotografia do acervo da FASU 
Depois de quatro dias de aquecimento, retira-se o carvão do braseiro e o perfil é deixado, de um dia para outro, para esfriar. Já frio, o mastro é novamente fixado com a chapelona para dar início à usinagem, alisamento da argila preparada, para dar forma à parte interna do perfil (ver Figura 66).

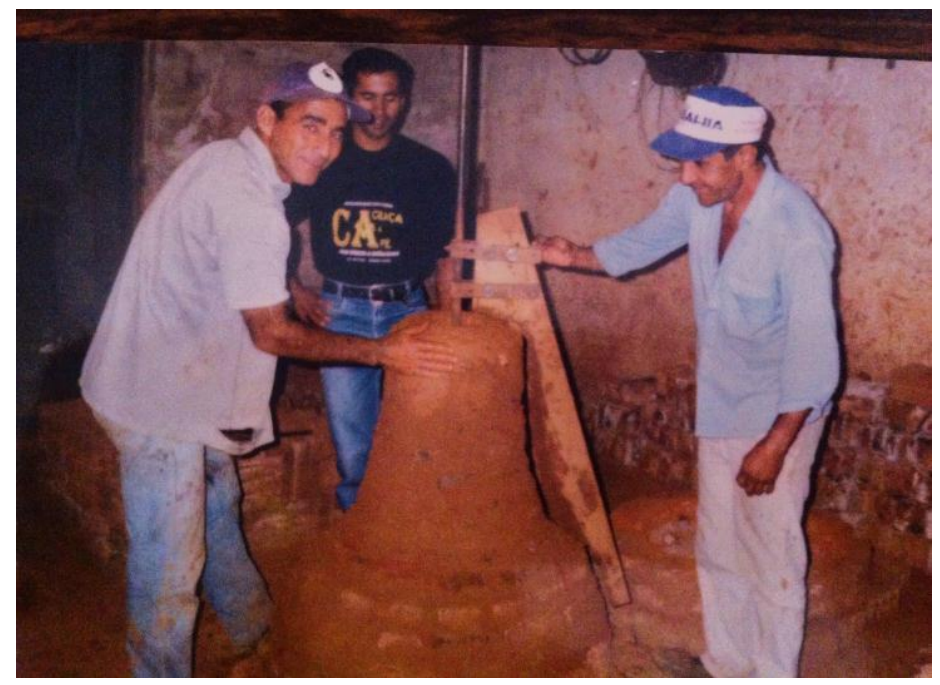

Figura 66. Usinagem do macho, parte interna do perfil. Fonte: fotografia do acervo da FASU

Deixa-se secar novamente. No dia seguinte, o perfil é usinado pela segunda vez até ficar liso; isso corresponde a duas mãos de argila e à parte interna do perfil, o macho (ver Figura 67).

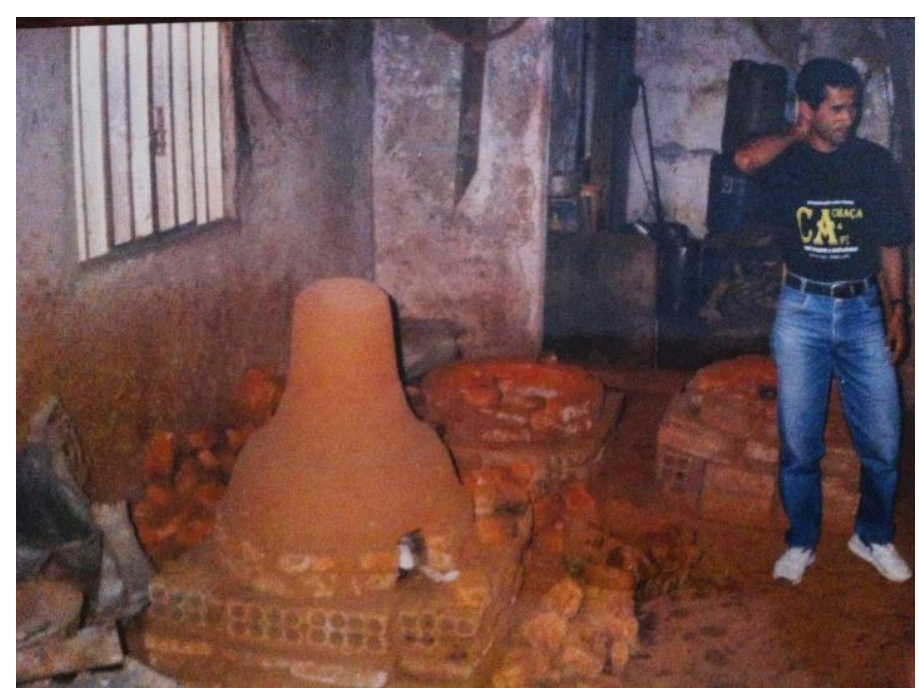

Figura 67. Macho usinado.

Fonte: fotografia do acervo da FASU 
Pronta a parte interna do perfil, inicia-se a etapa da parte externa com o segundo risco da chapelona. Nesse momento, é passado sobre a parte interna do perfil um unto, cinza com água (ver Figura 68), para não deixar uma parte grudar na outra porque a cinza; quando póe fogo, ela não desfaz, ela seca e não deixa a continuidade desse barro grudar no outro. Espera-se secar.

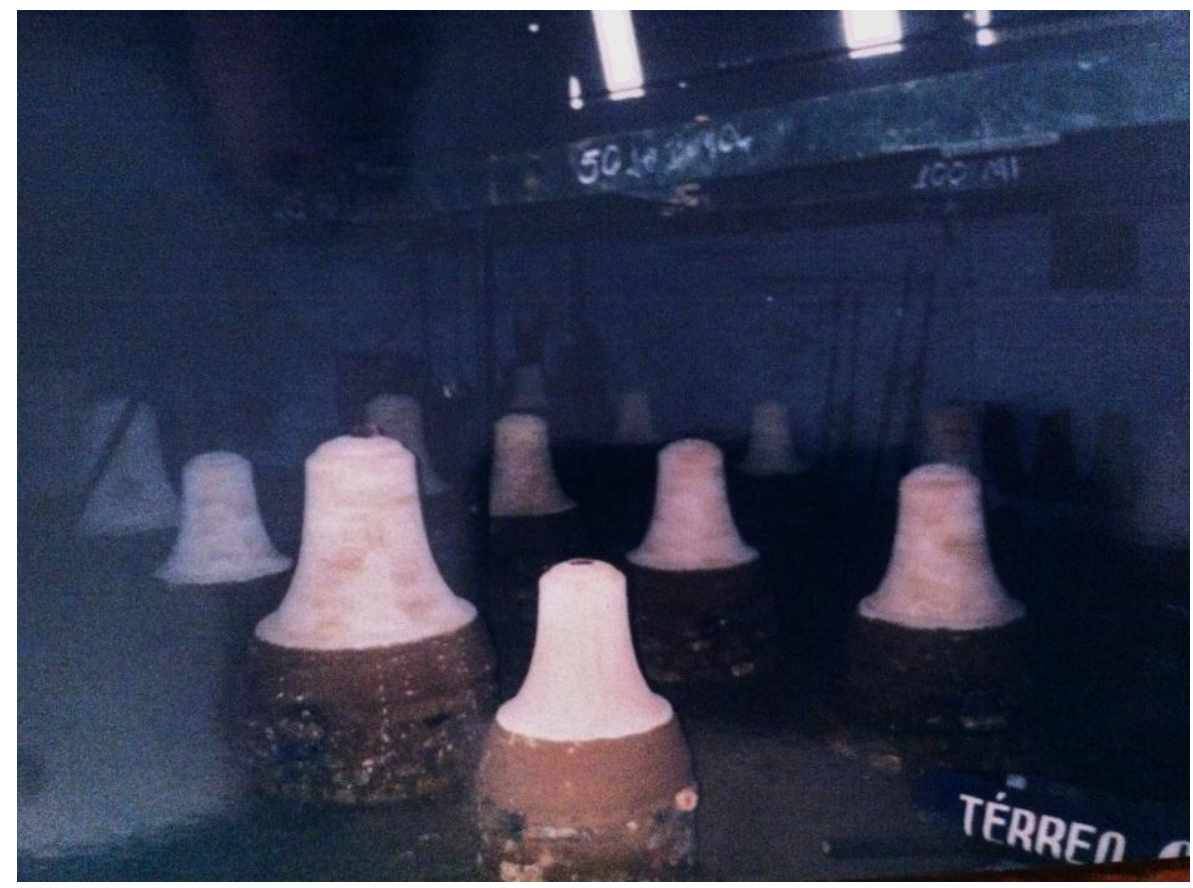

Figura 68. Machos com unto.

Fonte: fotografia cedida pelo Sr. Donizete do acervo da FASU

Depois de untada e seca a parte interna do perfil, é fixada a chapelona novamente, para, conforme o segundo risco, ser aplicada outra camada de argila fabricada, início da parte externa do perfil, que é chamado de modelo falso (ver Figura 69). A quantidade de argila usinada na parte superior do perfil é mais fina e vai engrossando até o final. Até a proximidade da boca, a quantidade de argila é três vezes maior que a de cima, para que o sino possa resistir à pancada do badalo. Após a usinagem, o perfil é aquecido com fogo no braseiro e deixado secar de um dia para outro. 


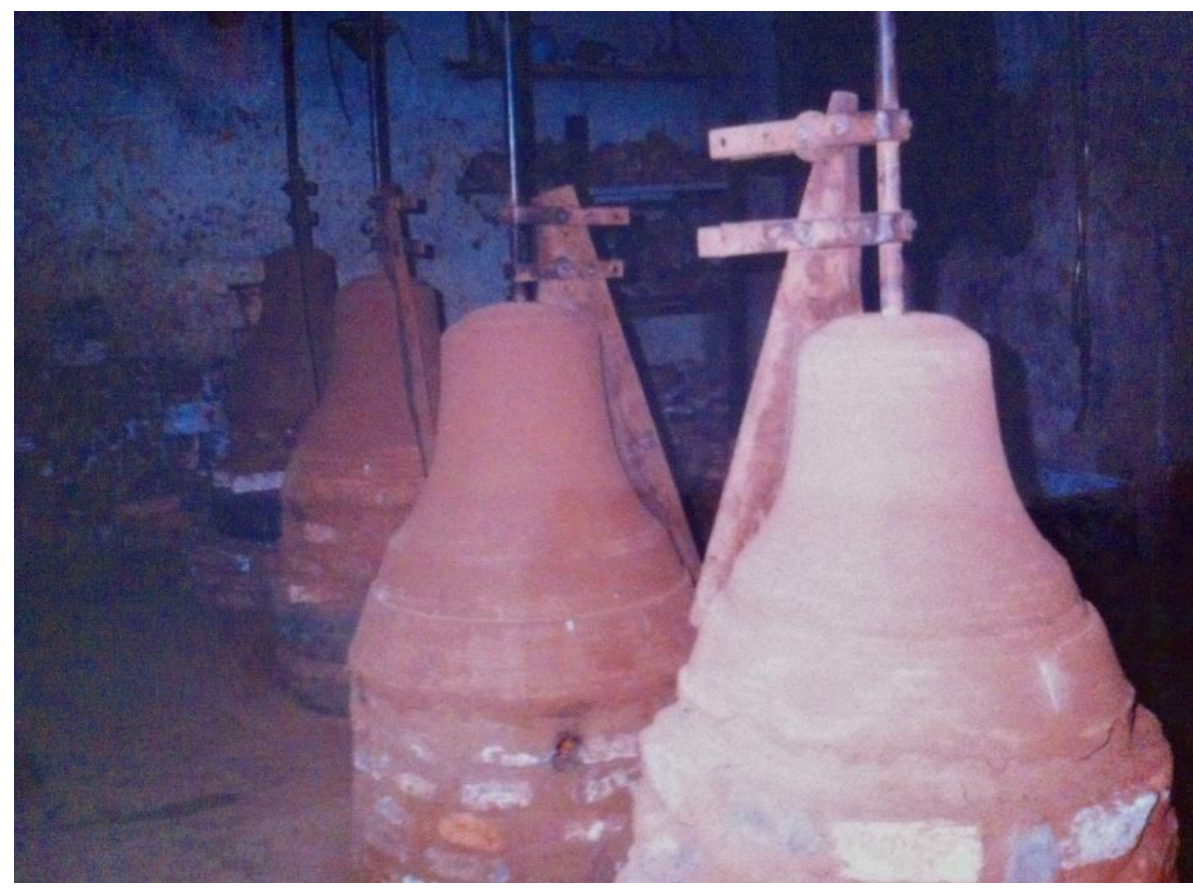

Figuras 69. Sinos usinados após o unto de cinza com água. Fonte: fotografia do acervo da FASU

O perfil usinado é limpo e raspado para dar início à aplicação do sebo (ver Figura 70). Com o auxílio da chapelona, aplica-se o sebo para traçar e marcar as linhas, que darão a dimensão de beleza do sino e orientarão a aplicação dos desenhos e gravações em cera (ver Figura 71). Os traços desenhados pela chapelona são, também, conhecidos como costelas do sino. Quando perguntado sobre a origem do sebo, o Sr. Donizete respondeu que pode ser de carneiro ou bovino. Salientou a importância de o sebo coagular, pois a banha não coagula; ela, ao invés de ajudar, ela atrapalha porque ela vai untar demais e vaíficar escorrendo. 


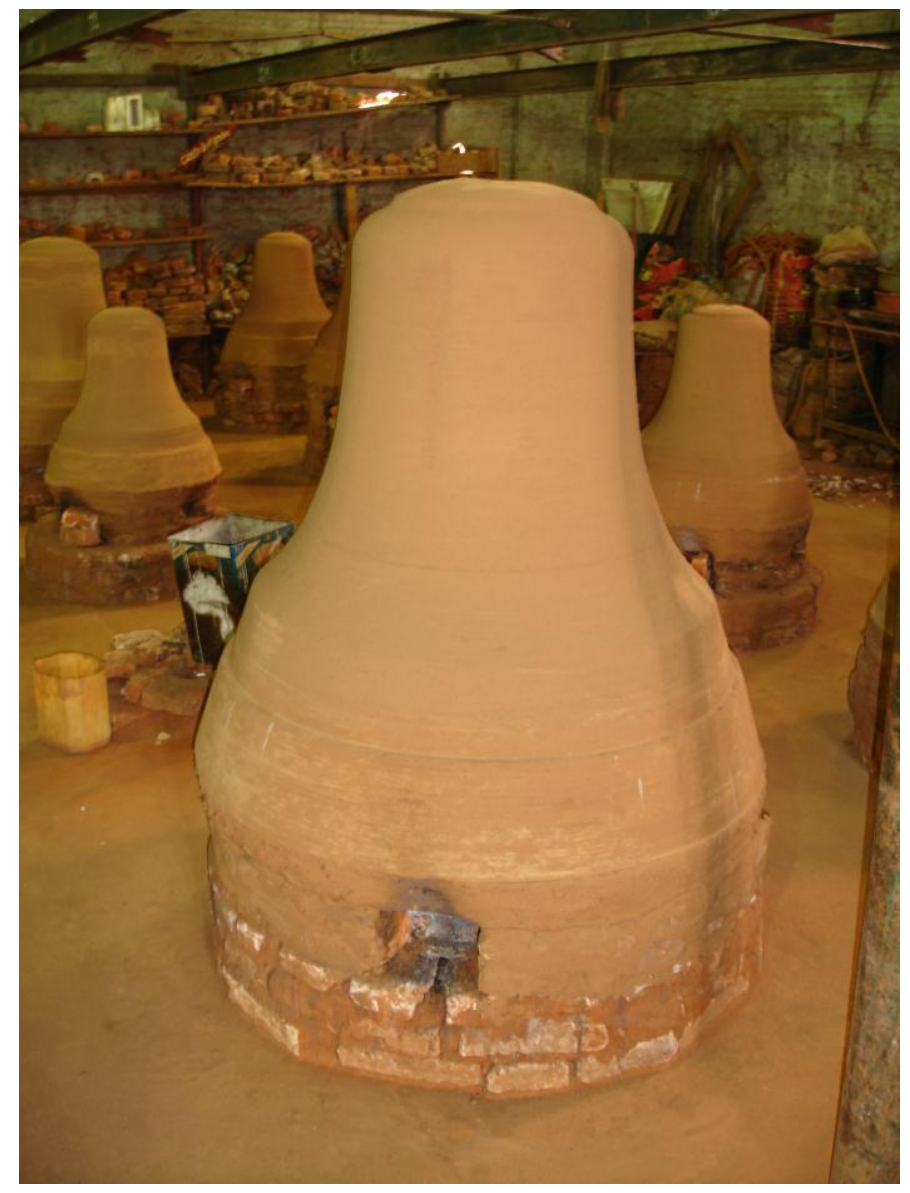

Figura 70. Sinos usinados e raspados.

Fonte: fotografia do acervo da FASU

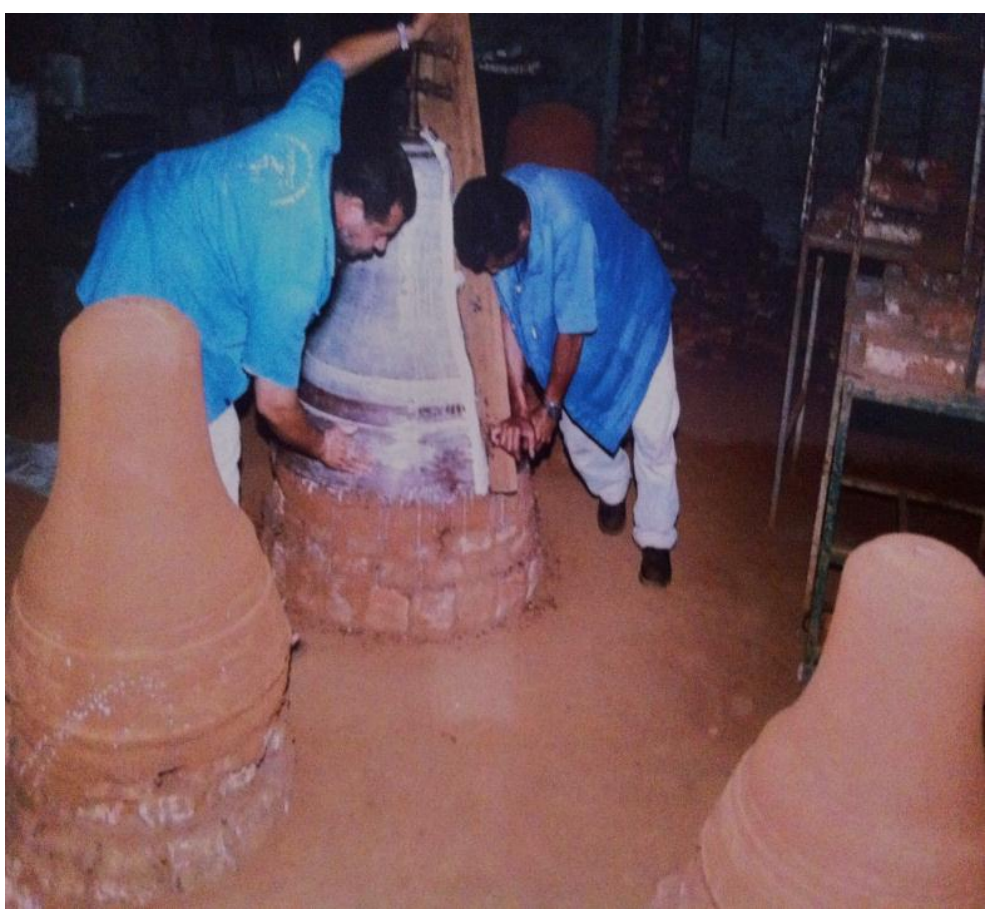

Figura 71. Sino raspado, aplicação do sebo com chapelona. Fonte: fotografia do acervo da FASU 
Após untar o perfil com sebo, são gravados os desenhos em cera no modelo falso. A cera pode ser aquela composta de cera da carnaúba e cera de abelha, macuinha, usada pelo escultor. Pela dificuldade em se conseguir a cera de carnaúba, é empregada a de marca Utilidade, que é industrial e usada no trabalho dos protéticos; ela é mais fácil de ser encontrada. Acrescenta-se a ela a parafina, que dá mais resistência e consistência. A medida de cera Utilidade e parafina para as letras e desenhos é de 1 para 1 e para a manilha do sino é de 1 para 3. Os desenhos ficam em relevo (ver Figuras 72 a 75).

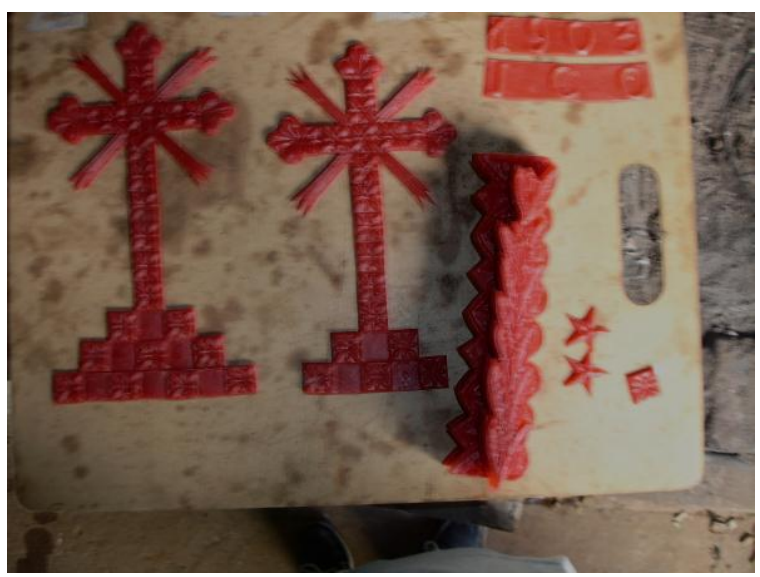

Figura 72. Desenhos em cera.

Fonte: fotografia do acervo da FASU

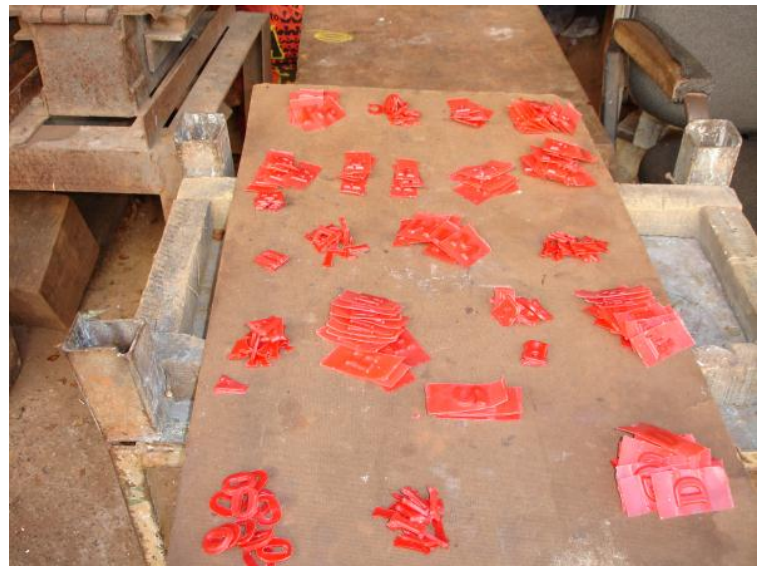

Figura 73. Letras e números em cera

Fonte: fotografada na visita de 17/11/2012 


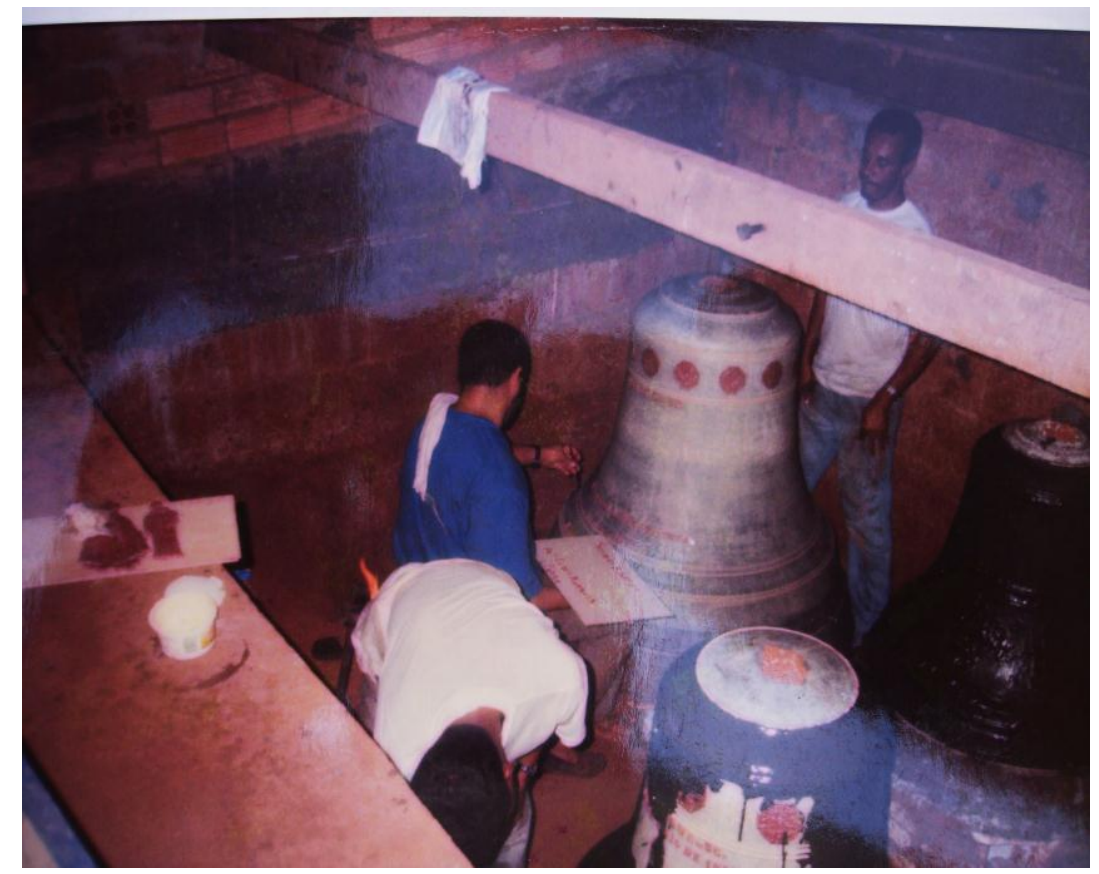

Figura 74. Gravação em cera após aplicação do sebo. Fonte: fotografia do acervo da FASU

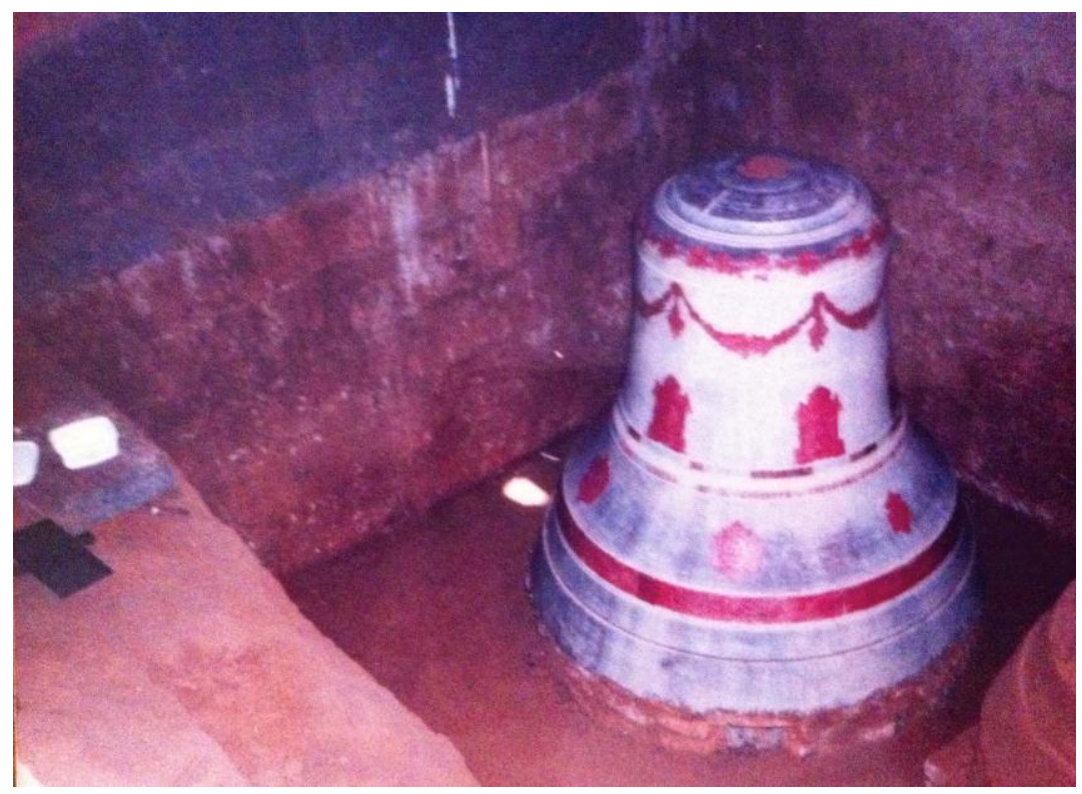

Figura 75. Finalizada a gravação.

Fonte: fotografia do acervo da FASU

Para copiar os desenhos, de modo que o perfil externo apresente-os, aplica-se um barro especial copiador chamado luto, devido a sua cor escura. Ele é fabricado com os seguintes ingredientes: pó de telha francesa queimada, pó de terra queimada, pó de gesso e melaço de cana. Tudo na mesma proporção, apenas 
o gesso tem que ser a metade do total para não ficar quebradico, pois a secagem é muito rápída. Por exemplo: duas medidas de pó de telha francesa + duas medidas de terra queimada + duas medidas de melaco = seis, acrescenta-se três medidas de gesso. Esse gesso do campo é uma pedra que a gente mó e forma o gesso, faz moldura para casa, usava, de primeiro, para fazer molde para dentadura. A terra queimada é a argila que, quando o sino é fundido, fica preta como carvão, conforme mostra a Figura 76.

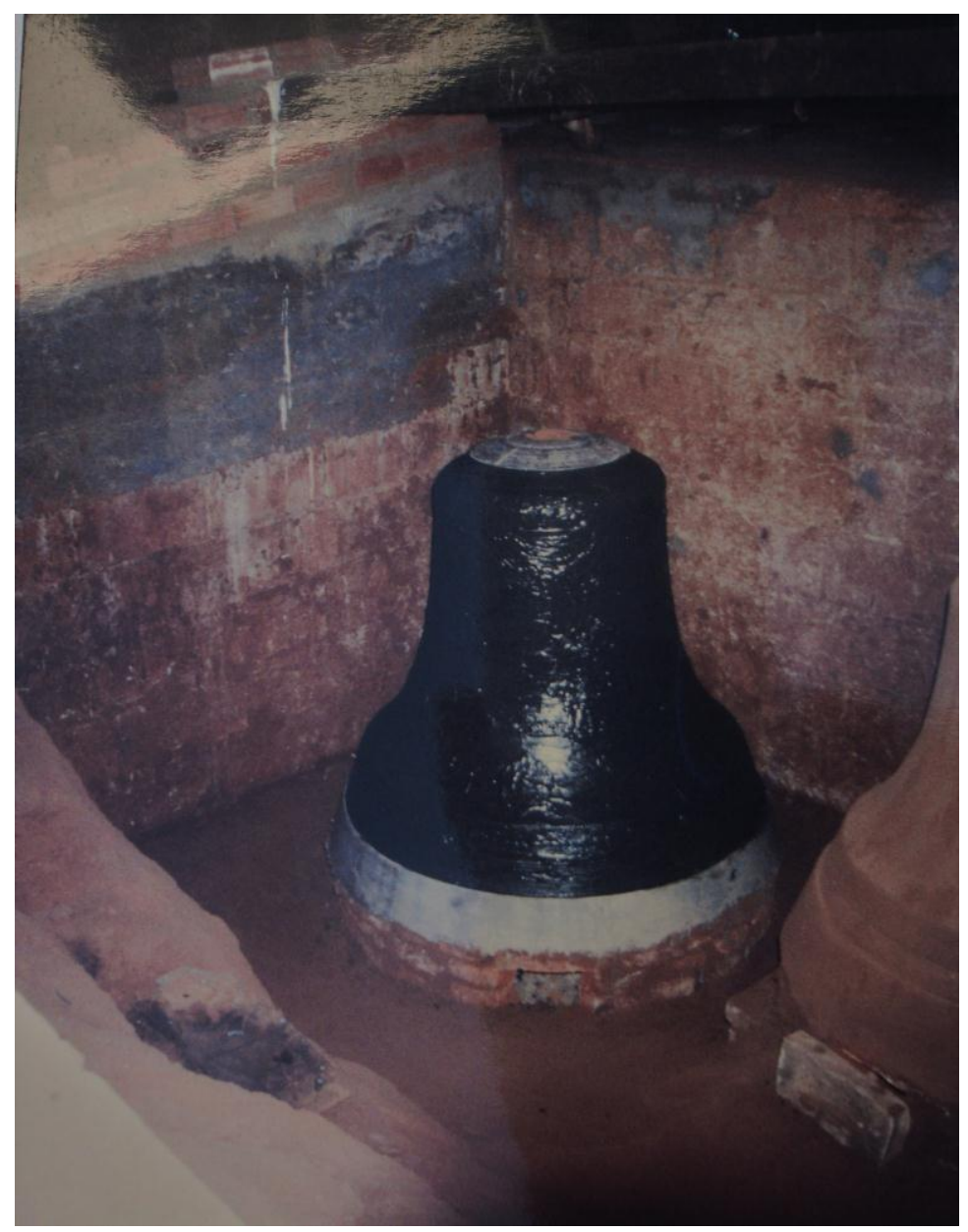

Figura 76. Barro copiador - luto, aplicado sobre a gravação. Fonte: fotografia do acervo da FASU 
O Sr. Donizete esclareceu que, na ausência do melaço, pode ser utilizado um preparado de açúcar, feito da seguinte forma: coloca-se $\sigma$ açucar dentro de uma vasitha com água e deixa três, quatro dias, ele vai chocando, chocando e derretendo. Quando derrete, aquela água doce, fedendo garapa, porque víra uma garapa, joga nesse complexo de pó: pó de gesso, pó de telha, pó de terra queimada e argita que queimou também. Os quatro ingredientes são misturados, postos em uma barrica e deixados de um mês para outro para envelhecer. Como o luto está encharcado, durante esse período de 30 a 40 dias, vaú soltando aquele amido. Vaú fícando no fundo só aquela borra, aquela borra que vai condensando, vaí ficando no fundo, aquele barro fino é que fica concentrado. A água de cima é só para poder não deixar endurecer porque tem gesso. Se näo ficar dentro da água, ele endurece e o serviço fica perdido. Quando usar, tira aquela água com cuidado e póe de lado; usa o barro, o tanto necessárioe, depois, volta a água de novo, senão ele seca. Além dos quatro ingredientes, é preciso acrescentar pelo de cavalo ou carneiro ao luto porque $\sigma$ pelo animal enruga, modela o barro e trama, não deixando trincar. $O$ luto é passado com pincel e seca rapidamente.

Concluída a aplicação do luto, é fixada a coroa, cabeça do sino, que é feita com uma matriz de gesso. Dependendo do tamanho do sino, já existe um molde. Para utilizar a matriz de gesso, é necessário colocá-la na água para umedecê-la. Em seguida, despeja-se a cera quente, liquida, por cima, que não vaí grudar no gesso por ele estar úmido. Depois de alguns minutos, ele comesa a coagular; escorre-se $\sigma$ excesso e retura-se a bota [forma do gesso]. Assim, tem-se a coroa em cera, em partes, que são depois encaixadas (ver Figuras 77 a 79). A coroa é formada por seis manilhas unidas e, com o calor de uma chapinha aquecida, a cera é derretida e fixada ao perfil. Outra opção é unir as seis peças com cola. 


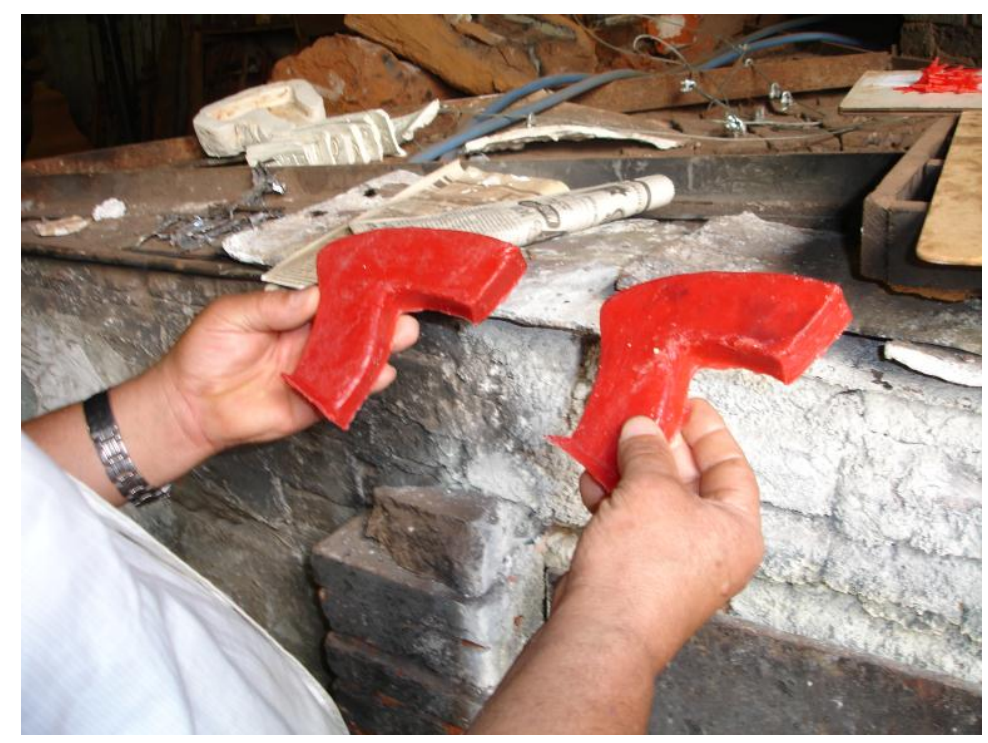

Figura 77 . Visão externa do molde das manilhas em cera. Fonte: fotografada na visita de 17/11/2012

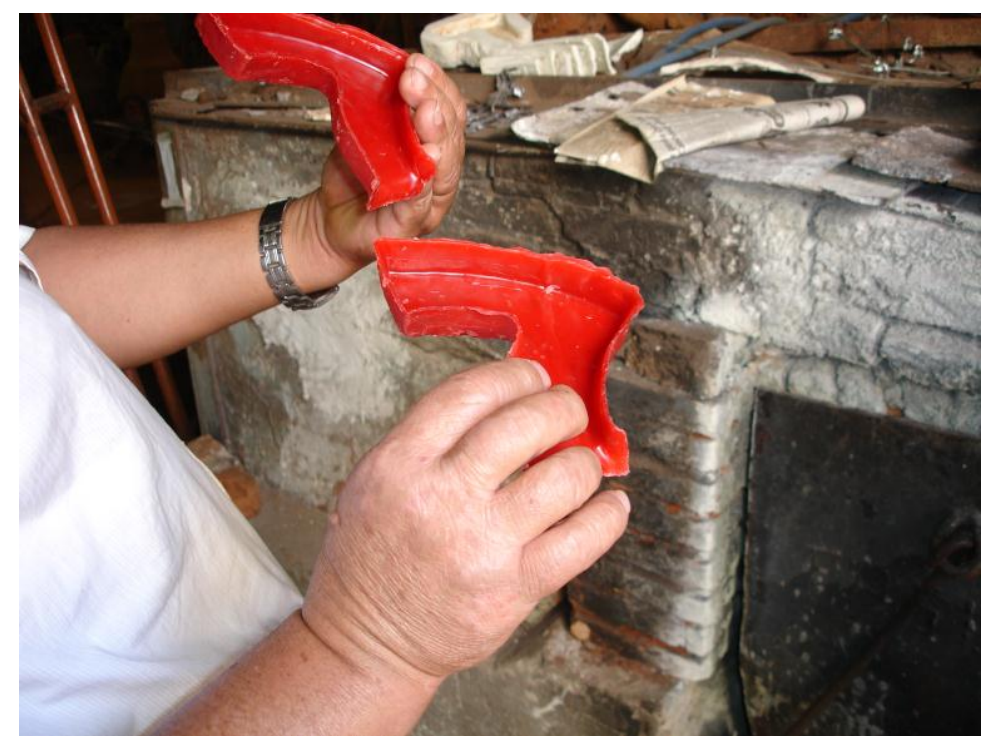

Figura 78. Visão interna do molde das manilhas em cera. Fonte: fotografada na visita de 17/11/2012 


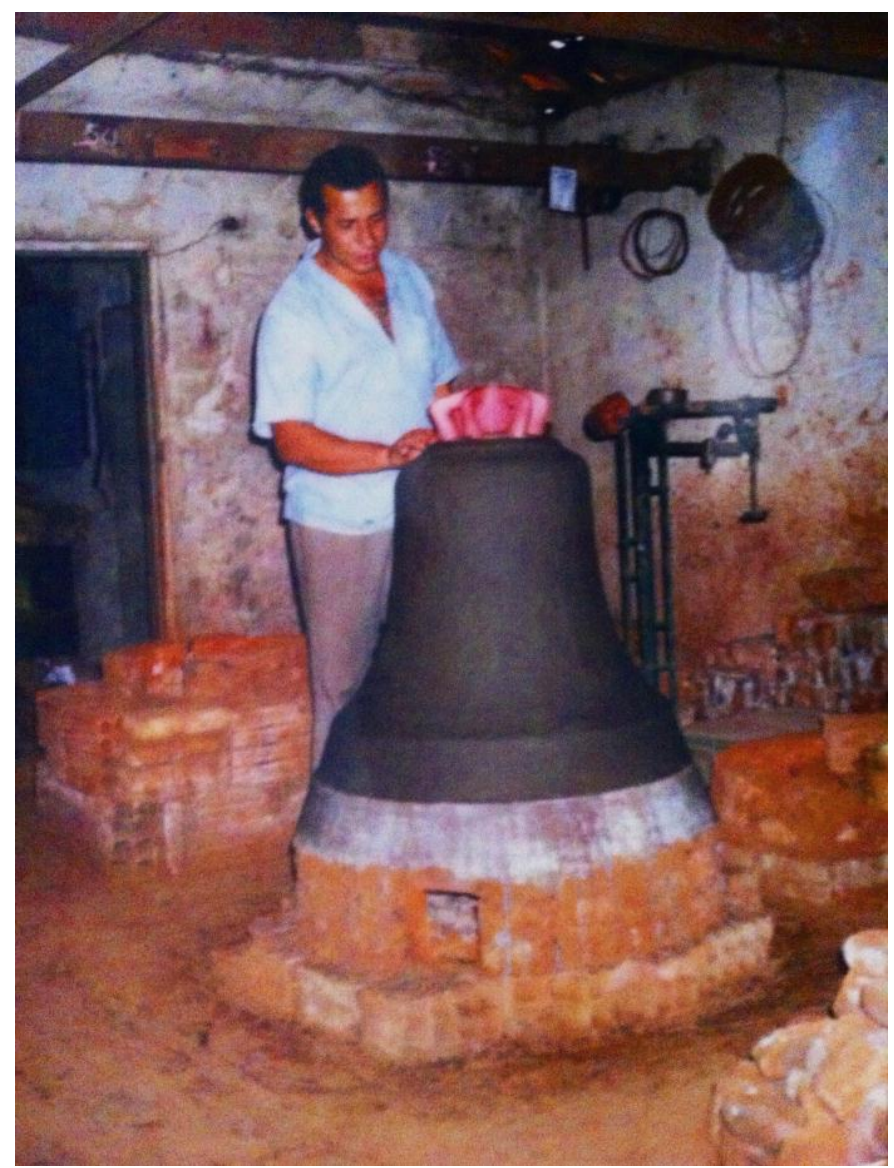

Figura 79. Fixação da coroa do perfil.

Fonte: fotografia do acervo da FASU

Afixada a coroa, o perfil é untado de argila fabricada com sisal e um pouquinho de gesso para secar rápido, porque o gesso acelera o processo de secamento. É a primeira camada da primeira fêmea, que irá cobrir todo o perfil e formar a camisa (ver Figura 80). Quanto mais fina, prejudica menos a gravação e seca mais rápído, passa-se um foguinho. O interior do perfil é preenchido com carvão em brasa. O perfil, sobre um cavalete, é transportado para o buraco (ver Figura 81), onde acontecerá a finalização do processo de fabricação até a fundição. 


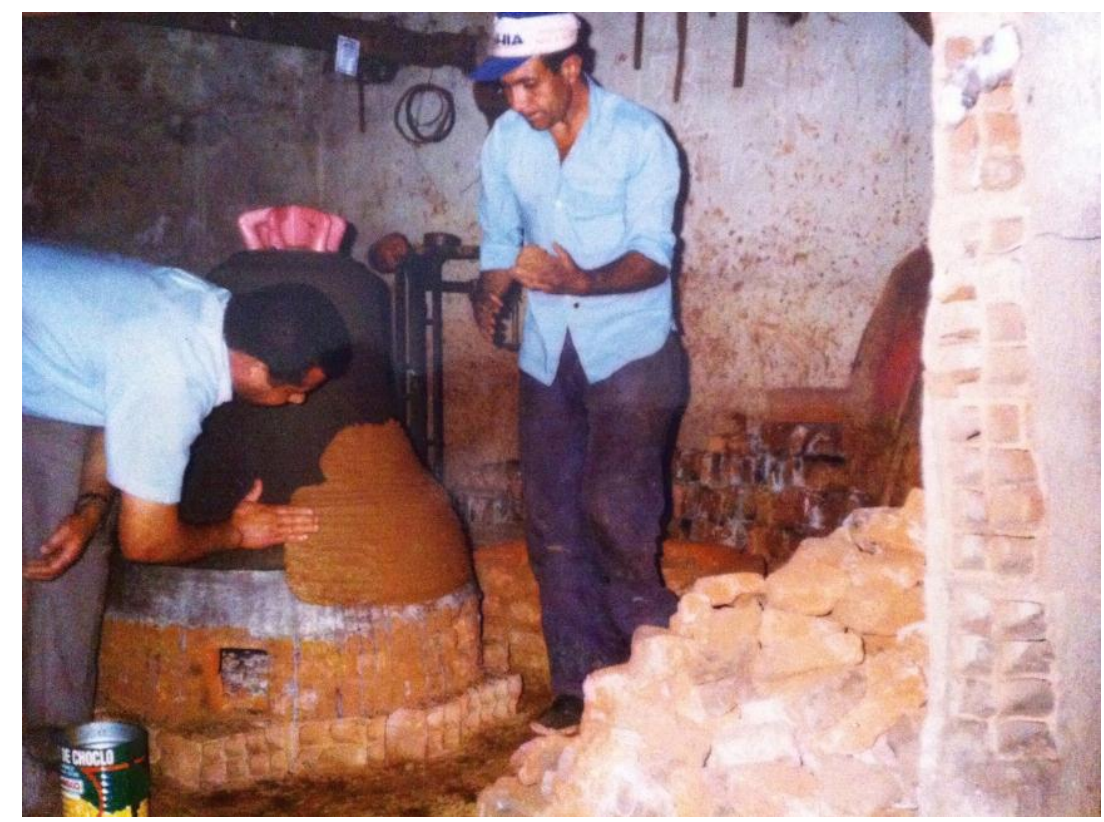

Figura 80. Cobertura do perfil, após o luto, de argila fabricada/1 $1^{\text {a }}$ fêmea.

Fonte: fotografias cedidas pela FASU

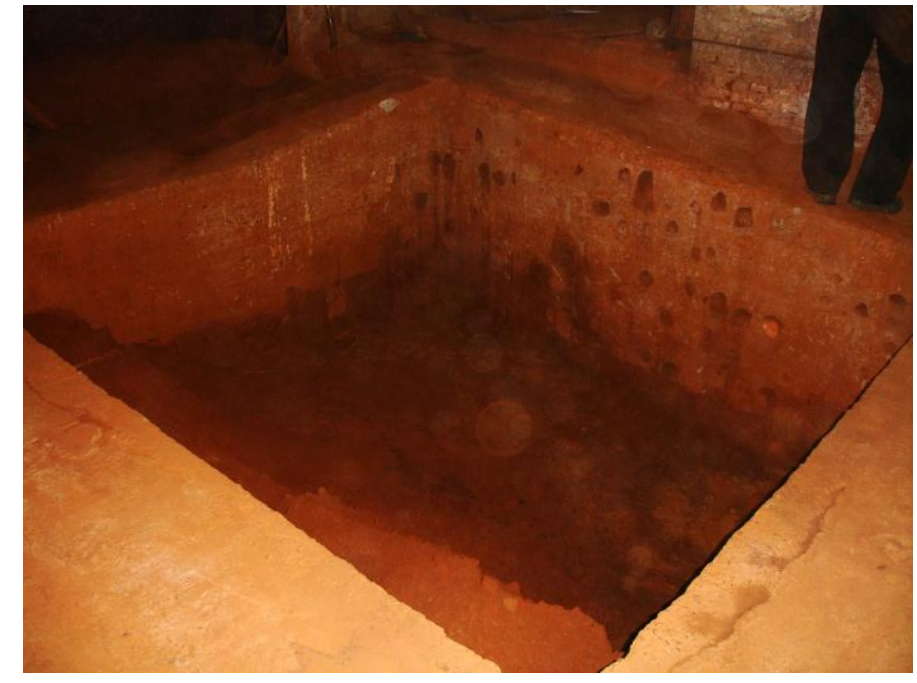

Figura 81. Buraco onde são colocados os perfis para fundição. Fonte: fotografado na visita de 20/07/2012

O sisal é desfiado e misturado à argila na quantidade necessária para que fique bem tramada porque senão a camisa trinca com o calor (ver Figura 82). $A$ trama tem que ser bem tramada porque se faltar ele trinca; onde faltar ele trínca. A argila fabricada com o sisal deve estar bem firme para não deformar o sino. 


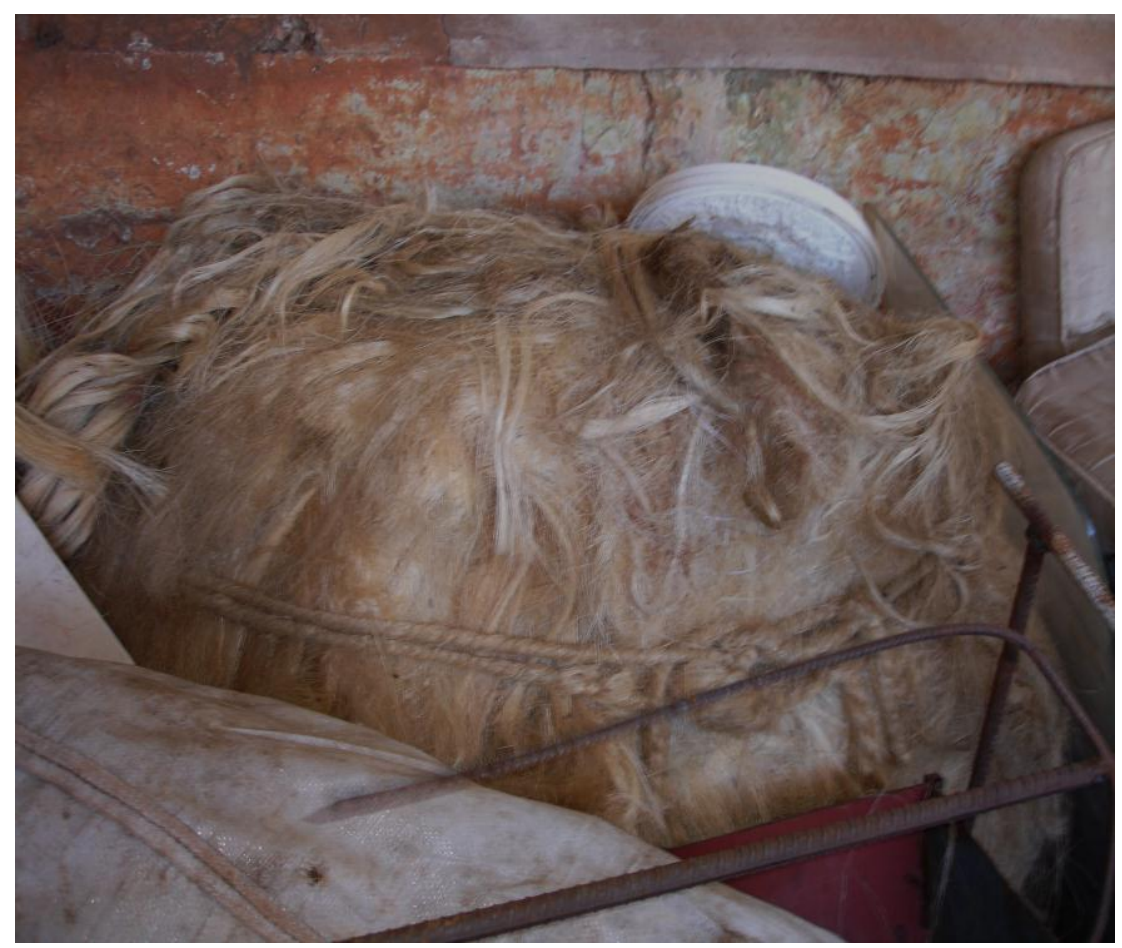

Figura 82. Sisal utilizado nas duas camisas/fêmeas.

Fonte: fotografado na visita de 20/07/2012

Nesse processo final da gravação, são transferidos para a primeira fêmea os desenhos fixados no modelo falso, parte externa do perfil. Após a usinagem da primeira fêmea, prepara-se a separação das manilhas com a cobertura de barro e restos de tijolos miudinhos entre elas, barro e tudo para poder fechar o complexo, material seco da natureza e refratárío, de modo que toda a coroa seja preenchida. Depois da cabeça pronta, com um pequeno ferro é preciso fazer, no molde, os três orifícios: um de entrada do bronze e dois laterais para respirolsuspiro. O bronze entra rápido e é preciso sair rápido o gás (ver Figura 83). 


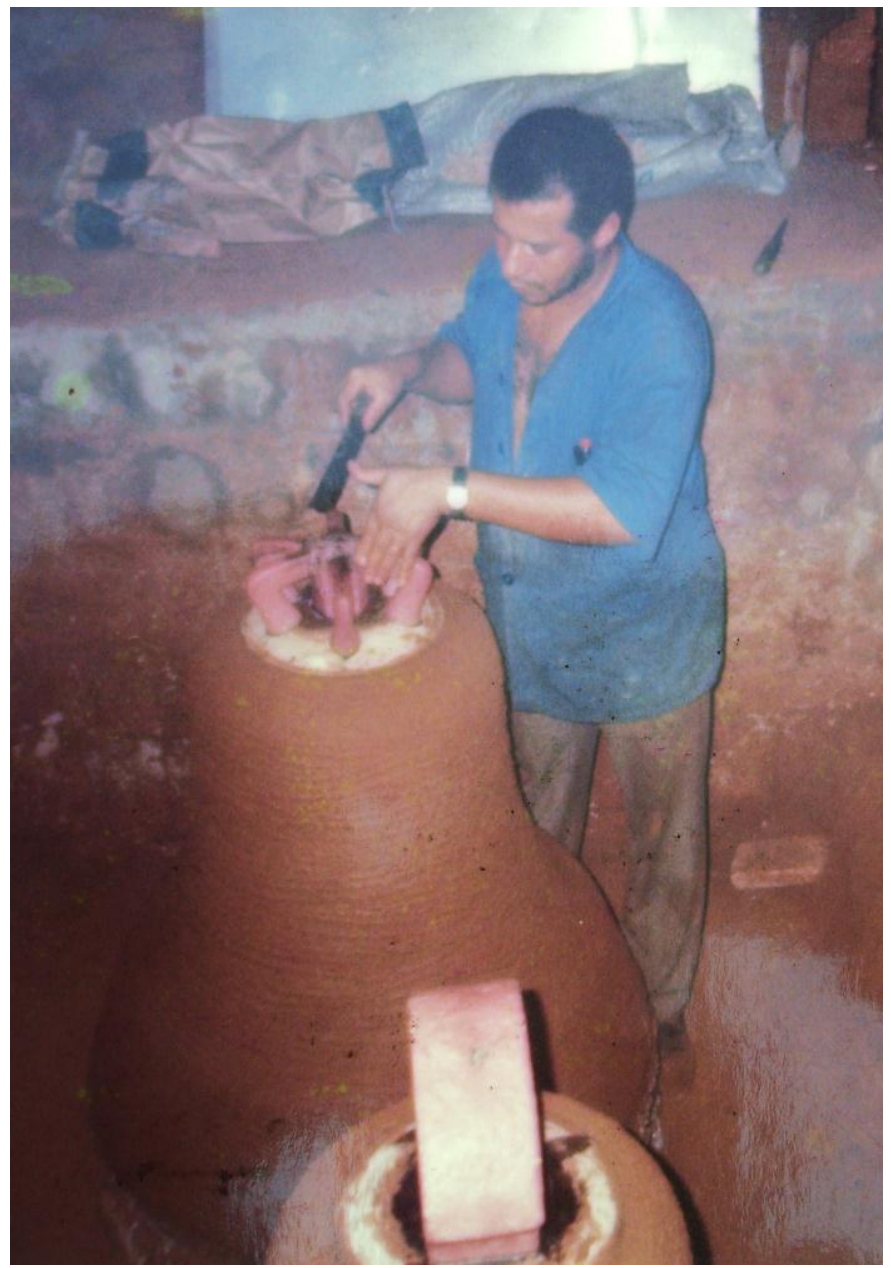

Figura 83. Abertura dos furos nas manilhas. Fonte: fotografia do acervo da FASU

Em seguida, é feita a cobertura do perfil até a coroa com uma camada mais grossa de argila fabricada com sisal (ver Figura 84). É a camada de reforço, segunda fêmea sobre a primeira fêmea, que cobriu a gravação, fazendo uma peça única, a camisa. A primeira fêmea, que foi fixada ao luto, tem a forma dos desenhos. Na peça única, formada pela primeira e pela segunda fêmea, é fixado um gancho lateral para retirá-la posteriormente. Há um furo na cabeca do sino por onde é introduzido carvão em brasa para secar todo o complexo. O sebo e a cera das gravações derreteram-se. As duas fêmeas tornam-se uma única camisa, que funciona como um forno, um tipo de cupúm do campo. 


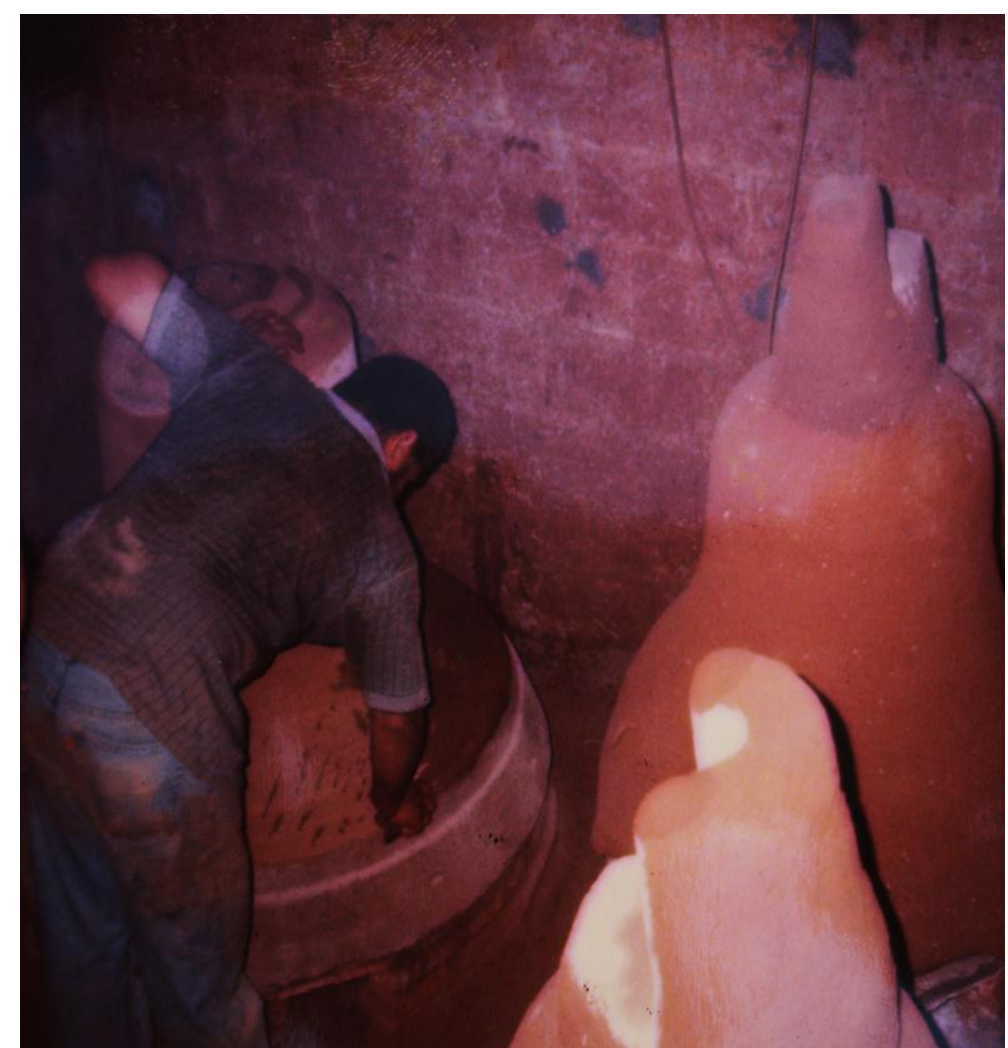

Figura 84. Cobertura do perfil para reforço da $1^{\mathrm{a}}$ fêmea, formação da $2^{\underline{a}}$ fêmea. Fonte: fotografia do acervo da FASU

Depois do perfil seco, é retirada a camisa (peça única formada pelas duas fêmeas) por meio de um guincho, de forma a não danificar a peça, para remoção do modelo falso (ver Figura 85). Após a retirada do modelo falso, limpa-se o unto sobre macho para ser aplicada a cinza com leite cru sobre o macho. O leite cru, tipo $C$ ow $A$, no natural não pode ser fervido porque se ferver queima a cola do leite e tem que ter cola (ver Figura 86). O leite também não pode ser pasteurizado. O leite com cinza é refratárío e um isolante, resiste ao calor intenso e não permite que o macho grude na fêmea. Ao passar a cinza e $\sigma$ leite para preparar a fundicão com metal, coloca aquele ganchinho [fixa-se o gancho do badalo na parte superior do sino com a retirada do modelo falso] lá dentro e deixa de espera. Ficam duas pontas só de grapa, pondo bronze, ele prende. 


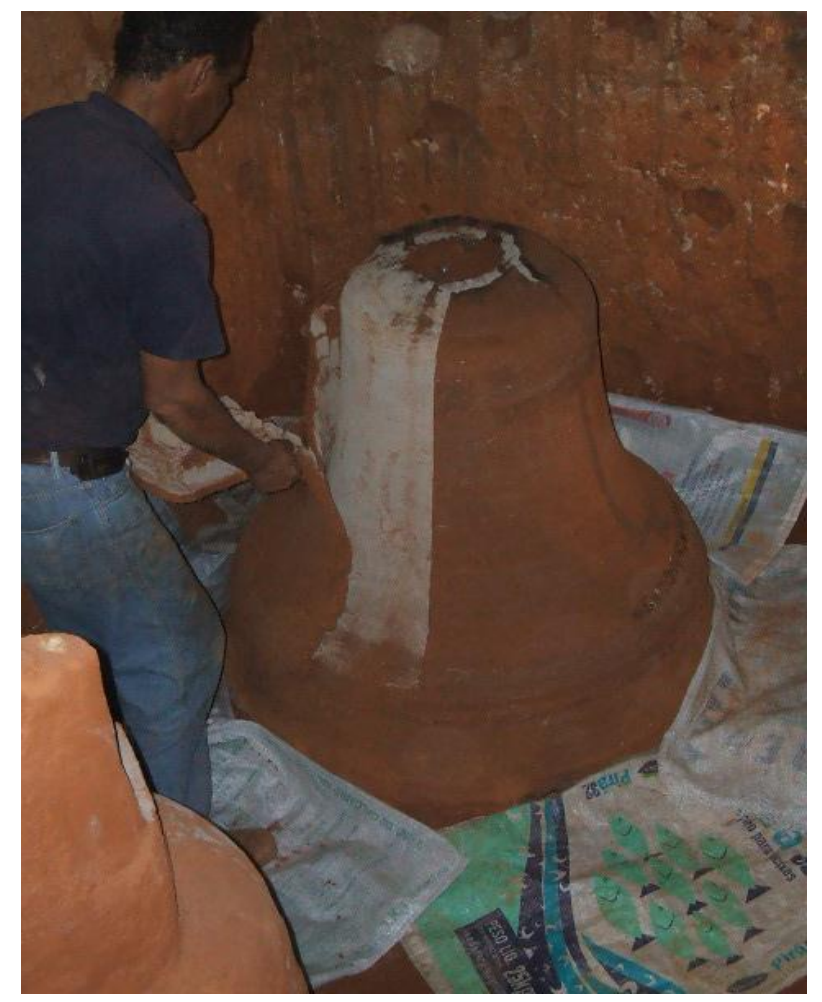

Figura 85. Retirada do modelo falso. Fonte: fotografia cedida pela FASU

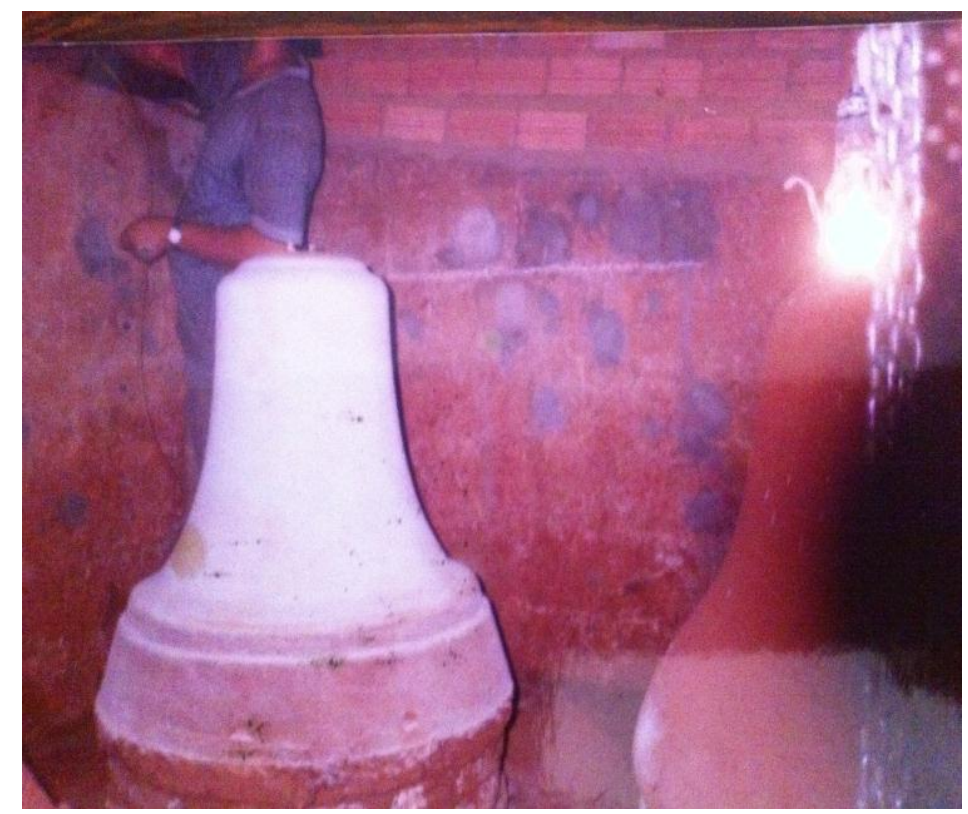

Figura 86. Modelo untado de cinza com leite com grapas. Fonte: fotografia cedida pela FASU 
São colocadas novamente as fêmeas (a mesma camisa que havia sido retirada pelo guincho) sobre o perfil. Todo o complexo é aquecido em brasa (ver Figura 87). Com a retirada do modelo falso, dá-se espaço para passagem do bronze, entre o macho e a camisa.

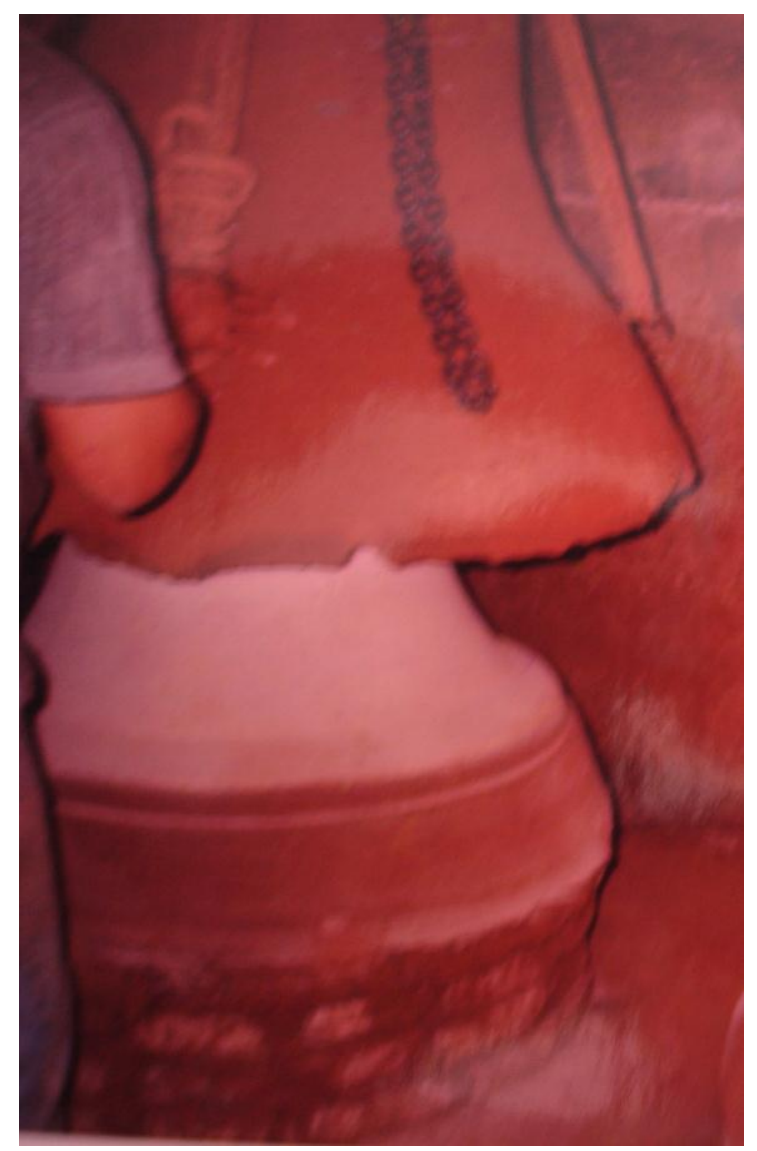

Figura 87. Após o leite, a camisa é depositada e o complexo é aquecido. Fonte: fotografia cedida pela FASU

Toda a coroa está coberta, ficando apenas três orifícios visíveis e expostos, para entrada do bronze e respiro no momento da fundição (ver Figura 88). Esses orifícios, durante as secagens e transporte para o buraco, estiveram lacrados com bucha e barro. Na hora de fundir, são retirados os lacres para receber o bronze. 


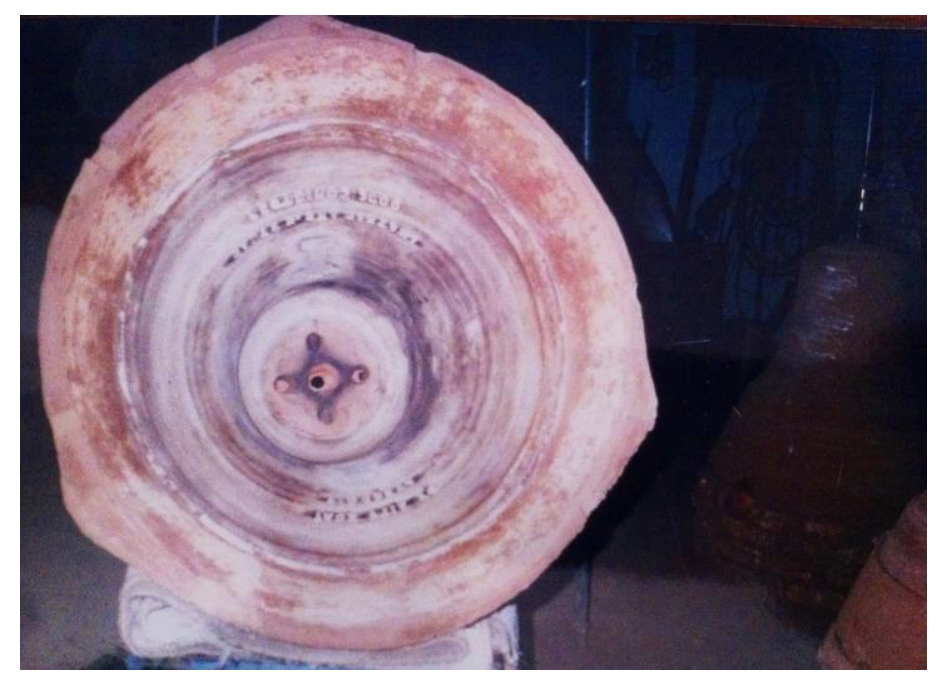

Figura 88. Três orifícios, dois respiros laterais e o central para passagem do bronze. Fonte: fotografia do acervo da FASU

A parte superior da camisa é o copo, que vaú funcionar como entrada do bronze e saida das impurezas e gases. Ela é feita antecipadamente porque leva uns três dias para ficar pronta. Ela é reaproveitada para várias fêmeas e é afixada com argila (ver Figura 89). Cobre-se completamente o perfil com a fêmea.

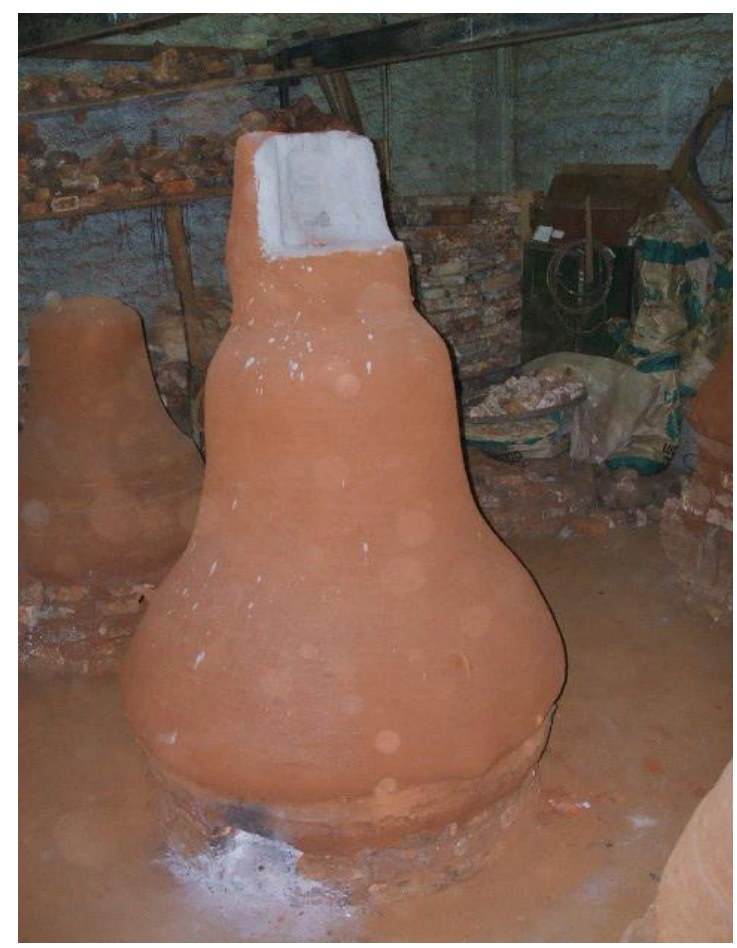

Figura 89. Perfil fechado.

Fonte: fotografias cedidas pela FASU 
Após o fechamento dos perfis e seu nivelamento dentro do buraco, é despejada terra úmida sobre eles (ver Figura 90). Devido à alta pressão e temperatura, é preciso prensar bem a terra, para que, com a entrada do bronze, a forma não arrebente e o metal não vaze. Cada camada de terra úmida colocada sobre as formas é de vinte centímetros compactados. Essa terra tem que ser mantida úmida, pois vai ficar guardada por um mês. Para isso, durante esse tempo, ela é molhada frequentemente de forma a manter a umidade, pois, se estiver seca, não prensave o servícó éperdido.

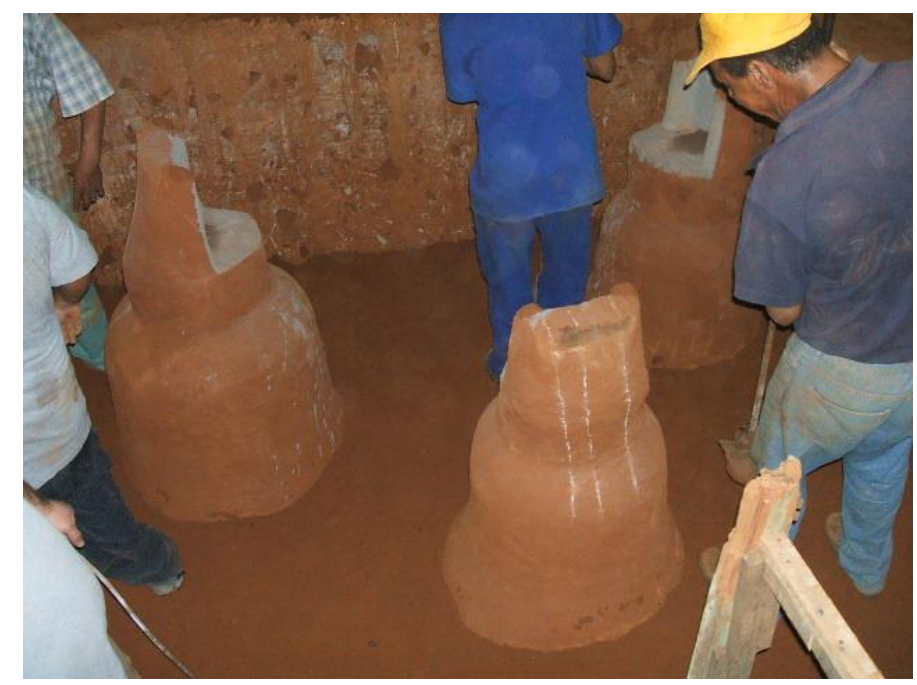

Figura 90. Prensa das formas para serem fundidas. Fonte: fotografia do acervo da FASU

Ao explicar sobre o metal utilizado para a fabricação de sinos, o Sr. Donizete esclareceu que o bronze puro não existe na natureza, ele é um material ligado com outros metais. Ele utiliza o bronze som, que é feito com estanho e cobre. A porcentagem adotada na liga é de $80 \%$ de cobre e $20 \%$ de estanho para o clima do Brasit. Lá para a Europa, que é mais frío, pode ser $79 \%$ de cobre e $21 \%$ de estanho. Um pouco de niquel serve para endurecer, para resistir mais à pancada. Altera-se a liga, $78 \%$ de cobre, $20 \%$ de estanho e $2 \%$ de niquel. 
No caso dos sinos nordestinos, para deixá-los mais resistentes, substituise o níquel pelo zinco, na proporção de $78 \%$ de cobre, $20 \%$ de estanho e $2 \%$ de zinco, pois o modo de badalar, conforme afirmou o Sr. Donizete, é pancando, ou seja, batendo com força. Opta-se pelo zinco por ser mais barato que o níquel.

Para derreter os metais que constituirão a liga, é utilizado um forno, que fica no alto, acima das formas. Para aquecer o forno é utilizado o carvão mineral ou óleo diesel. Na fornalha, pela portinhola, colocam-se os lingotes e as peças para derretimento (ver Figuras 91 e 92).
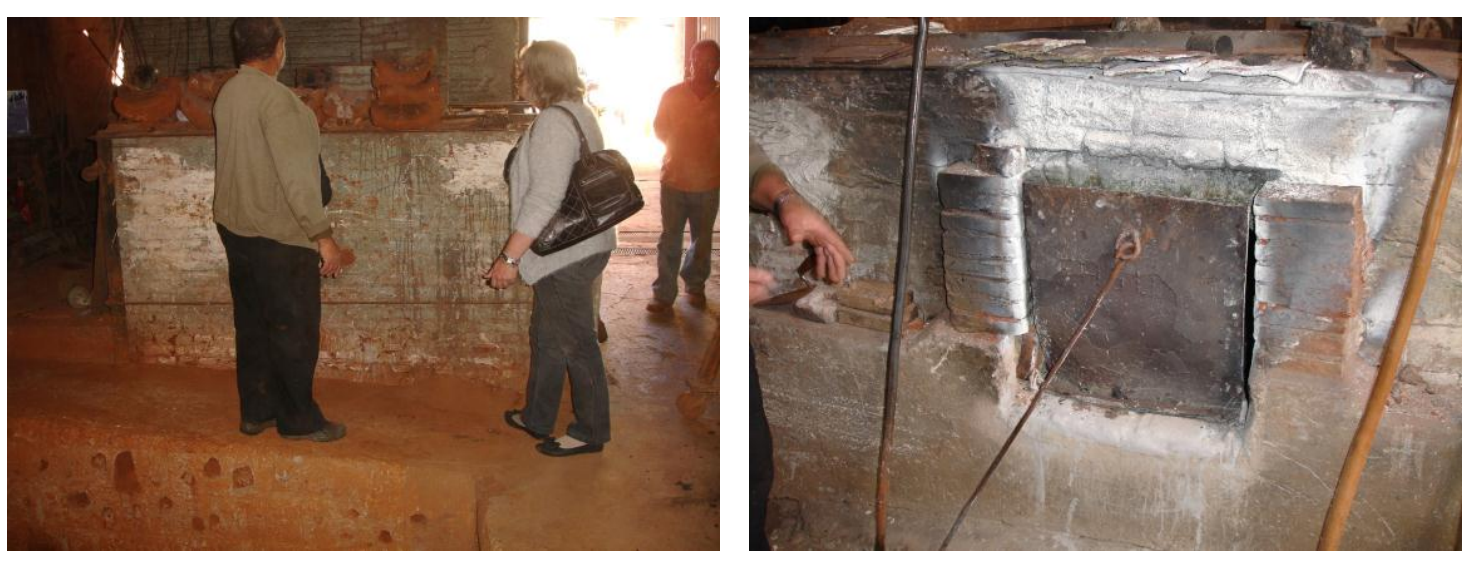

Figura 91 e 92 . Fornalha frente ao buraco.

Fonte: fotografadas na visita de 20/07/2012

Se for utilizado o carvão mineral, os lingotes são colocados em uma panela de grafite, o cadinho. Esse procedimento não tem ocorrido mais, segundo relatou o Sr. Donizete, porque o carvão mineral, que é de Santa Catarina, é mais dispendioso e, além disso, há a política de preservação.

Com a opção do óleo diesel, todo o material é colocado em uma panela inctinada a favor da descida do sangramento do bronze. $O$ diesel sai do tambor, desce e cai na frente do macarico, que está sobre uma pequena panela com fogo (óteo e pano); desse modo o diesel fica aquecido. Como o interior da fornatha é redondo, ocorre a reverberação.

Depois de certo tempo, para misturar os metais, é utilizado um caibro, porque o bronze não gruda na madeira e [ao mexer os metais no cadinho] 
elimina o gás que pode estar acumulado. Ao mexer o metal dentro da fornalha, verifica-se a existência de algum caroço de lingote que ainda não tenha sido derretido, conforme mostra a Figura 93.

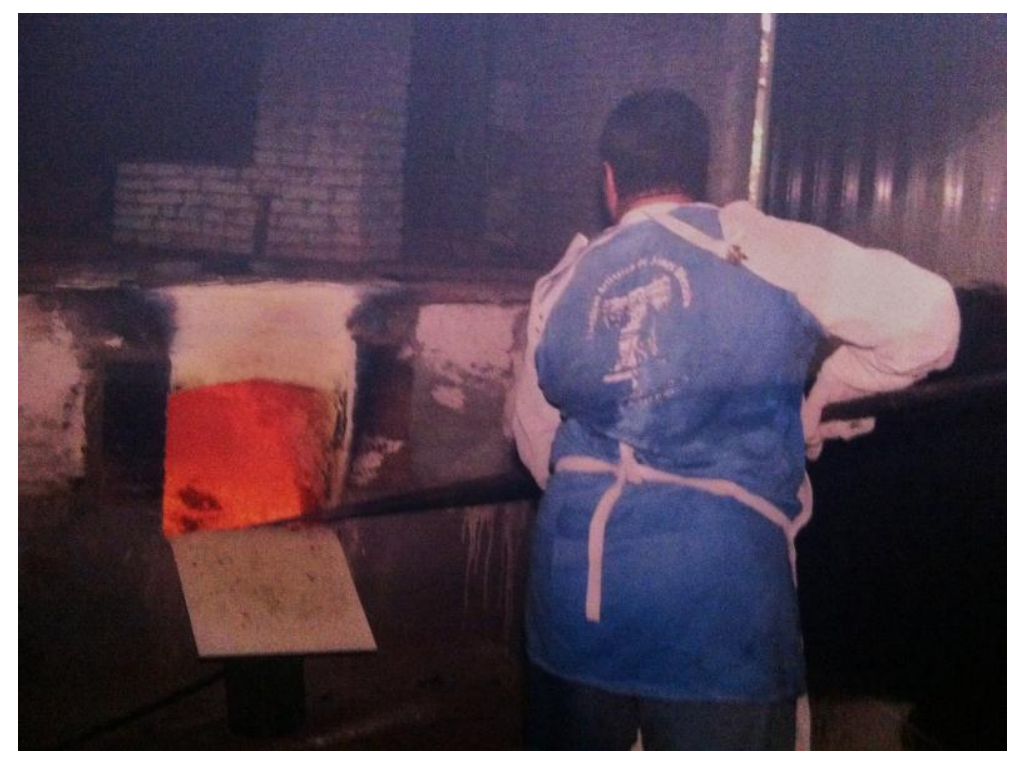

Figura 93. Forno- material quase todo derretido.

Fonte: fotografia cedida pelo Sr. Donizete do acervo da FASU

Para controlar a temperatura, o Sr. Donizete utiliza uma haste de madeira. Essa técnica ele aprendeu com o italiano Crespi. Com a queima da madeira, ele checa a intensidade do calor.

A parte que foi dentro do forno para mexer o bronze e para ver o quanto ele queima - porque, ao enfiar e mexer, puxa e vê se queimow um metro - é 1000 graus. E, também, depois de muitos anos vai treinando pela hora. No começ, começa com uma hora de fogo. Uma hora de fogo já sabe que vai avermelhar. Com duas horas, aquele vermetho já está mais denso; com três, começa a fícar pastoso, quer dizer, está começando a querer derreter. Com três horas e meia, está derretendo; com quatro horas, já derretew. 
Agora, com quatro horas e meia, ele está de 900 para 1000 graus de excelêncía.

Pela experiência no ofício e observação, o Sr. Donizete salientou que os lingotes são colocados a favor das labaredas e que quando é retirado o tampão de dentro da fornalha, $\sigma$ bronze vem sangrando e furioso. $O$ bronze, quanto mais aquecido, mais rápído ele escorre. Pela observação e o tempo da hora, é possível saber o tanto que derreteu, diz o Sr. Donizete. Esse gás é tóxico e, por isso, é preciso o uso de máscaras. Mesmo sabendo disso, o Sr. Donizete confessou que ele e seus funcionários esquecem-se, frequentemente, de usá-las, por estarem muito envolvidos com o trabalho.

Rapidamente, a haste mostra quando chega a $1100^{\circ} \mathrm{C}$, momento que indica não precisar aquecer mais, pois senão estraga a forma. Tudo preparado, coloca-se a corredeira do forno, sempre com queda, até as canaletas para escorrer até os orifícios das formas dos sinos, conforme mostram as Figuras 94 a 96.

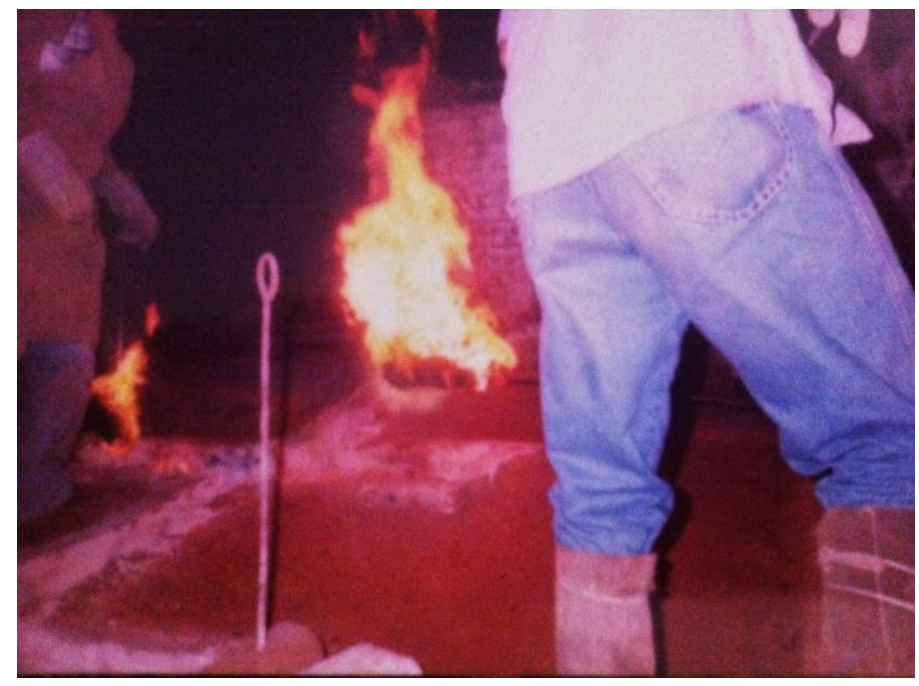

Figura 94. Ato da fusão, o material escorre pela caneleta. Fonte: fotografias cedidas pelo Sr. Donizete do acervo da FASU 


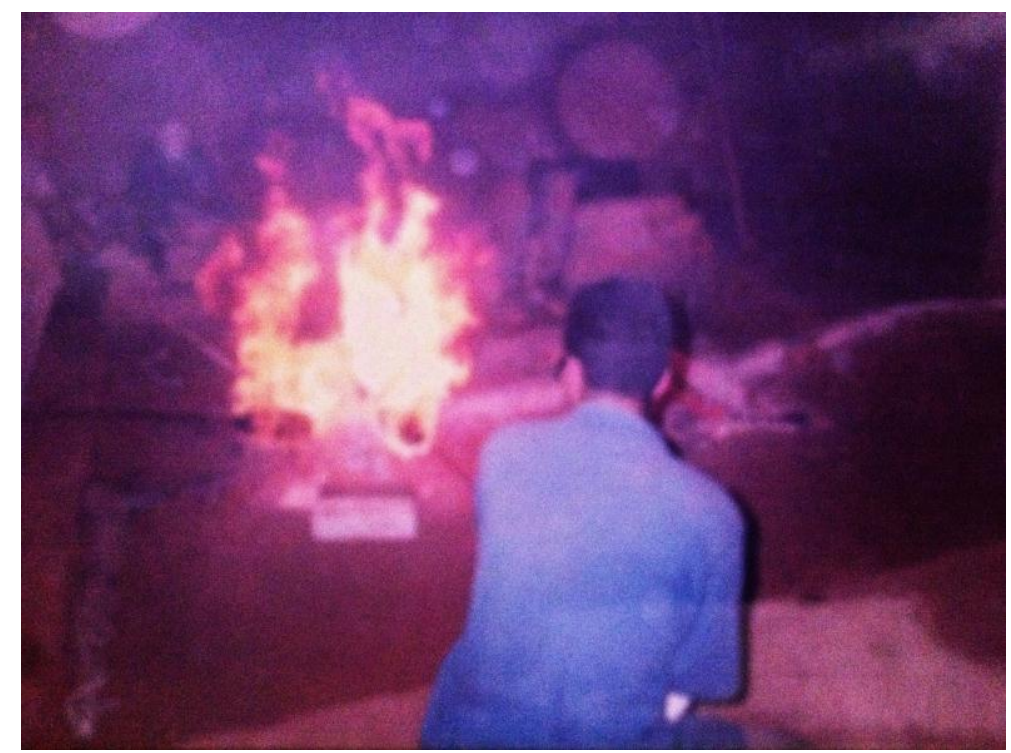

Figura 95. Etapa de fusão, descida pelas caneletas. Fonte: fotografia cedida pela FASU

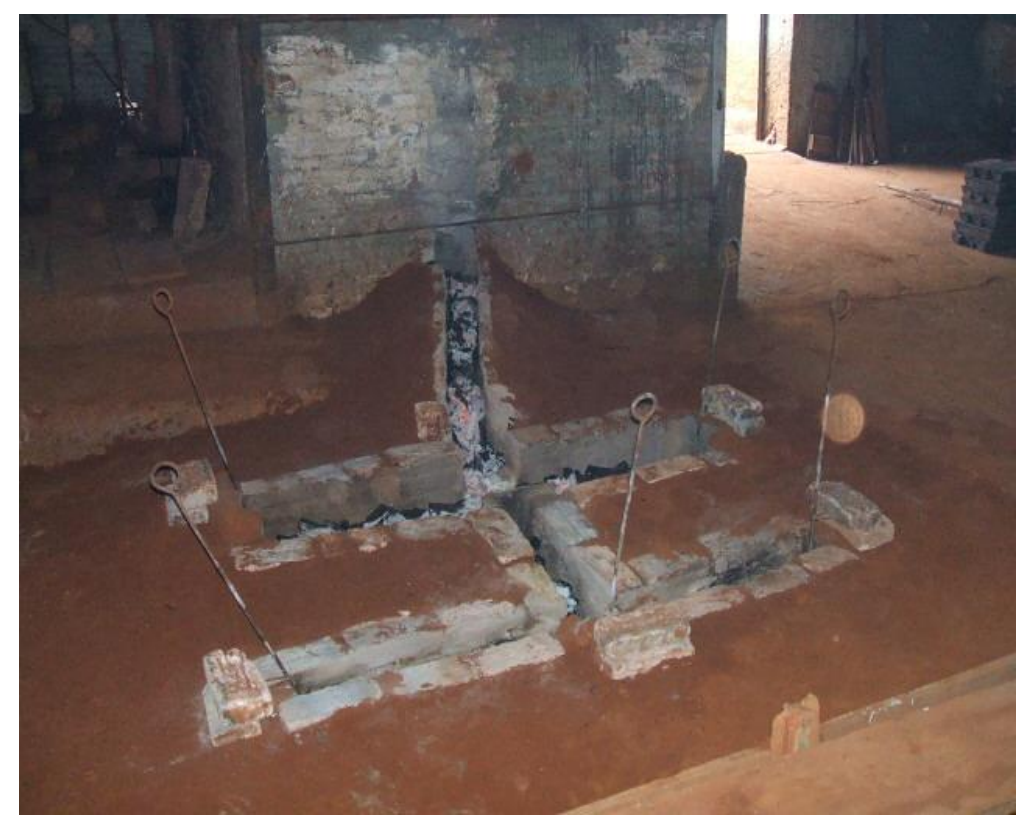

Figura 96. Canais de escoamento do bronze. Fonte: fotografia do acervo da FASU

Ao chegar às formas, o metal, que estava a 1000 graus, chega d forma a 970 graus, porque recebew um pouco de vento. Essa 
temperatura é a ideal para fundir. Para saber a diferenca entre 1000 e 970 graus, é preciso atentar para o tempo que leva para escorrer o bronze porque, se ele estiver vagaroso, a 900 graus, significa que vai dar problema ao entrar na forma. Ele tem que entrar a 970 para 1000 graus; ele está mais liquido, então, ele vaí mais rápído. É questão de fechar o otho... para perder o servíco basta uma bobeirinha de nada. Se na hora que está fundindo, abre a porta, o vácuo do vento complica o materíal na descida.

Como mencionado anteriormente, o orifício central é onde entra o bronze e os dois laterais são os respiros, que fazem com que o bronze entre mais rápido, sem permitir que entre ar, pois caso isso aconteça, o processo de fundição é interrompido. E assim, o bronze não liga devido à presença do ar. Desse modo, a fundição não é realizada por inteiro e todo o serviço fica perdido.

É colocada uma caixinha sobre o sino, que funciona como recalque de peso para garantir a fundicáo, de uns quarenta a cinquenta quitos de reserva (depende do peso do sino), porque aí, quando ele repuxar, ele vai repuxar esse material da caixinha que a gente vai cortar e turar fora. Se repuxar aqui, fica danificado. Tem que deixar um massalote, a caixinha, para poder fazer peso no funditho. Se não tiver peso nele, ele murchave deforma; não é uma fusão perfeita (ver Figura 97). 


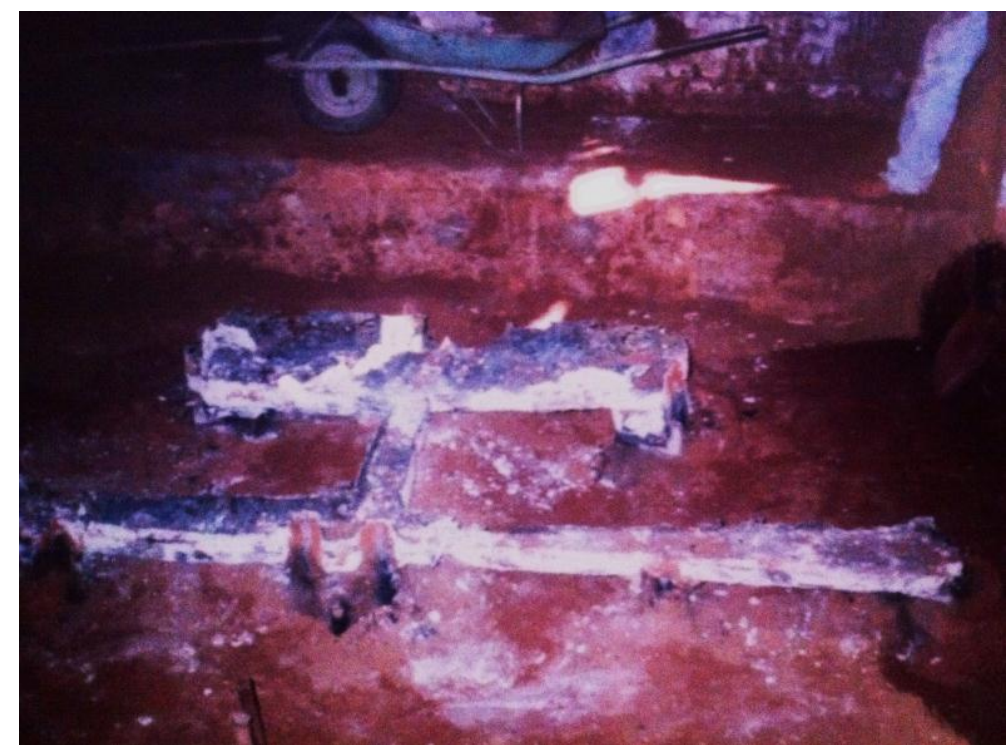

Figura 97. Sinos fundidos, prontos para serem desenterrados. Fonte: fotografia do acervo da FASU

Concluída a fundição, esperam-se 24 horas para mexer na terra e começar a retirada dos perfis de dentro do buraco. Cumprido o prazo, a terra é removida e guardada para ser reutilizada. Levam-se aproximadamente de 6 a 7 horas para a remoção dos sinos porque o trabalho é manual. Depois, os perfis são limpos para retirada do luto, conforme mostram as Figuras 98 e 99.

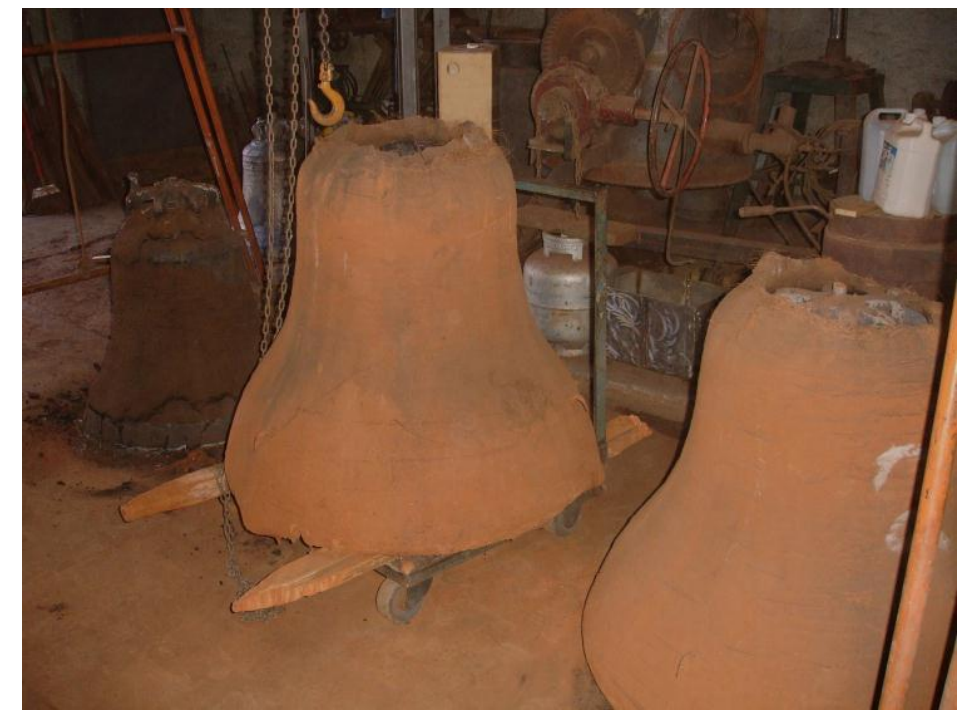

Figura 98. Sinos fundidos para retirada das fêmeas. Fonte: fotografada na visita de 20/07/2012 


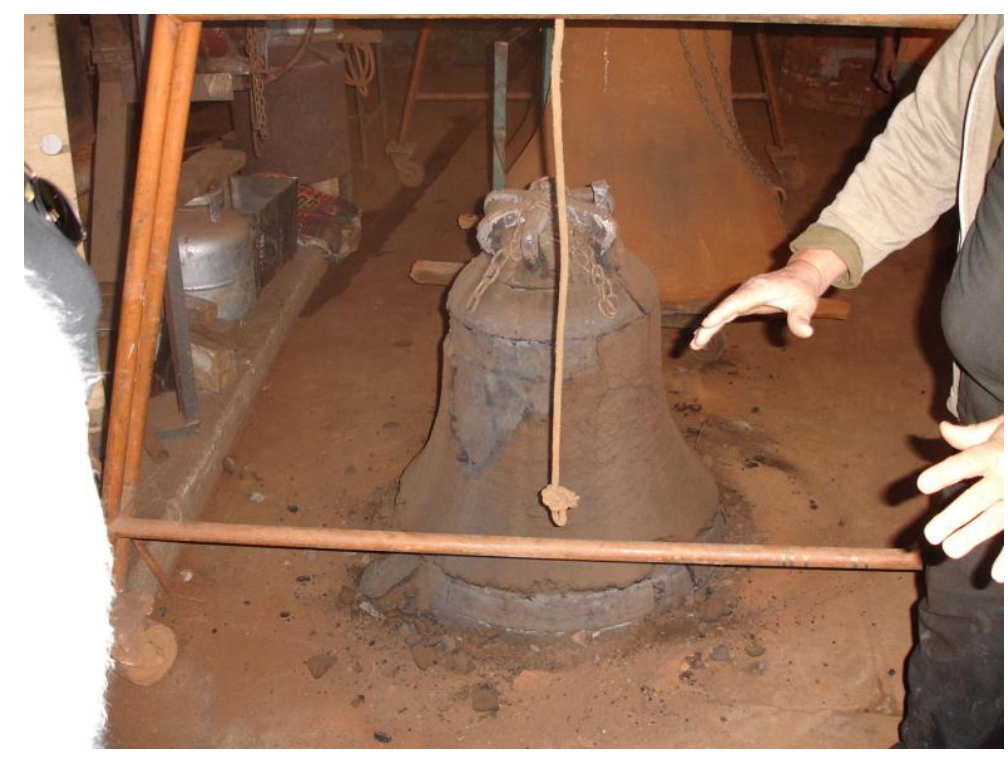

Figura 99. Remoção do Luto.

Fonte: fotografada na visita de 20/07/2012

Depois, o sino é emborcado para remoção de sua parte interna, composta de tijolos e argila, que são reaproveitados até ficarem bem pequenos, quando são usados no preenchimento da coroa. A terra queimada, retirada de dentro do perfil, é utilizada na produção do luto; já a externa não é reutilizada porque ela costuma vir com muita sujeira do bronze (ver Figura 100).

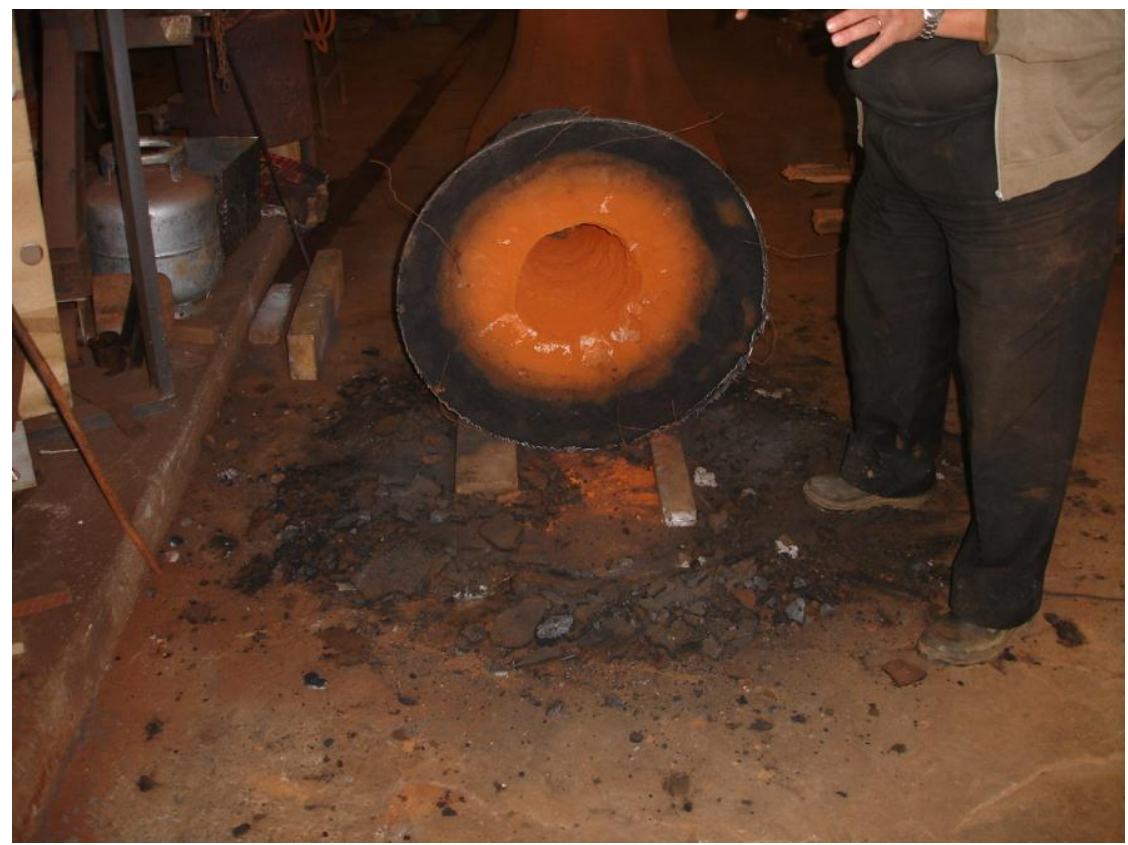

Figura100. Sino desenformado para retirada do macho. Fonte: fotografadas na visita de 20/07/2012 
A cinza do leite não faz mal, mistura com a do luto e pode ser reaproveitada. Ambas são refratárias enquanto têm consistência. Quando queimadas, não servem mais. A terra vermelha é guardada na cacamba e é jogada água, água de esterco; depois de três a quatro meses, ela volta a ser a mesma terra. $\mathcal{O}$ arame também pode ser aproveitado novamente.

Para melhor distinguir as etapas do processo de fabricação, é apresentado na Figura 101, um corte longitudinal de um perfil de sino.

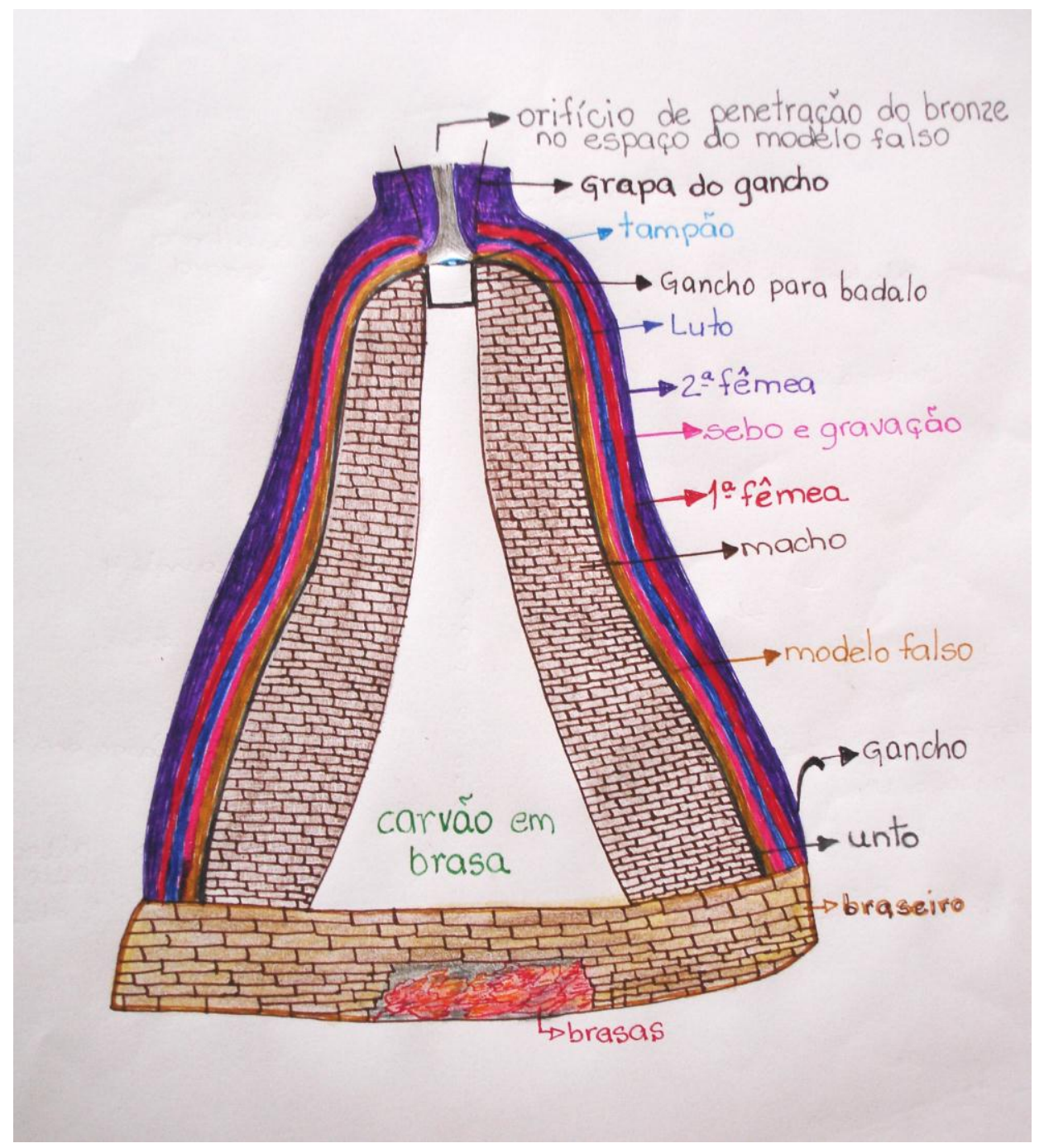

Figura101. Desenho do perfil de sino - corte longitudinal. Fonte: desenho da autora 
Em seu trabalho, o Sr. Donizete avalia todo o processo e identifica se alguma etapa não foi bem executada. Se ficarem rebarbas no bronze, por exemplo, significa que uma das etapas de secagem, após a usinagem, foi apressada, com superaquecimento no braseiro, o que provocou o trincar do perfil, pois, quando póe fogo lento, o perfit vaí queimando lentamente de uma semana a outra, não provocando fraturas no perfit, o que deixa o sino de bronze liso (ver Figuras 102 e 103). As rebarbas são retiradas com lixadeira na etapa de polimento do sino, assim como os frisos do luto.

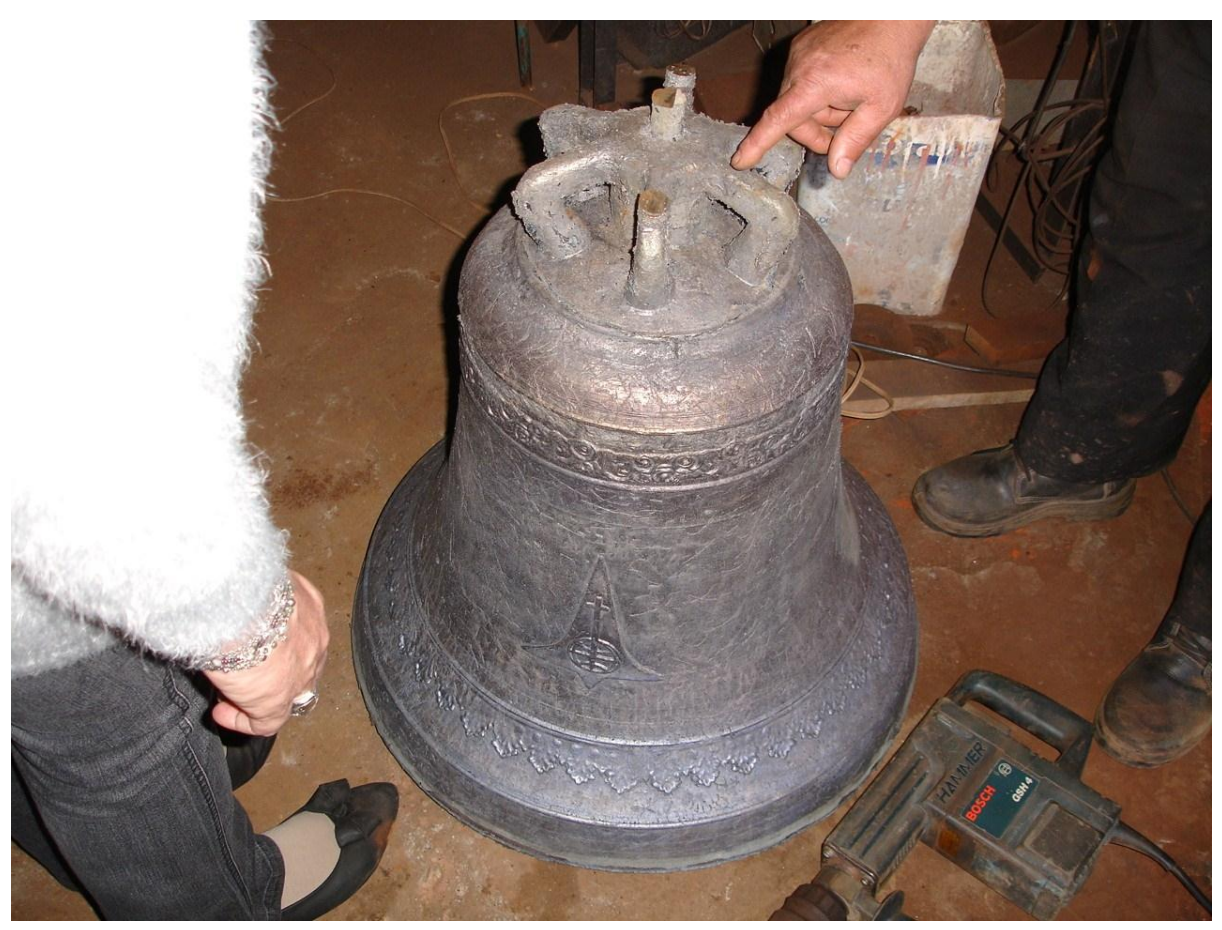

Figuras 102. Sino limpo para polimento- retirada das rebarbas. Fonte: fotografadas na visita realizada em 20/07/201 


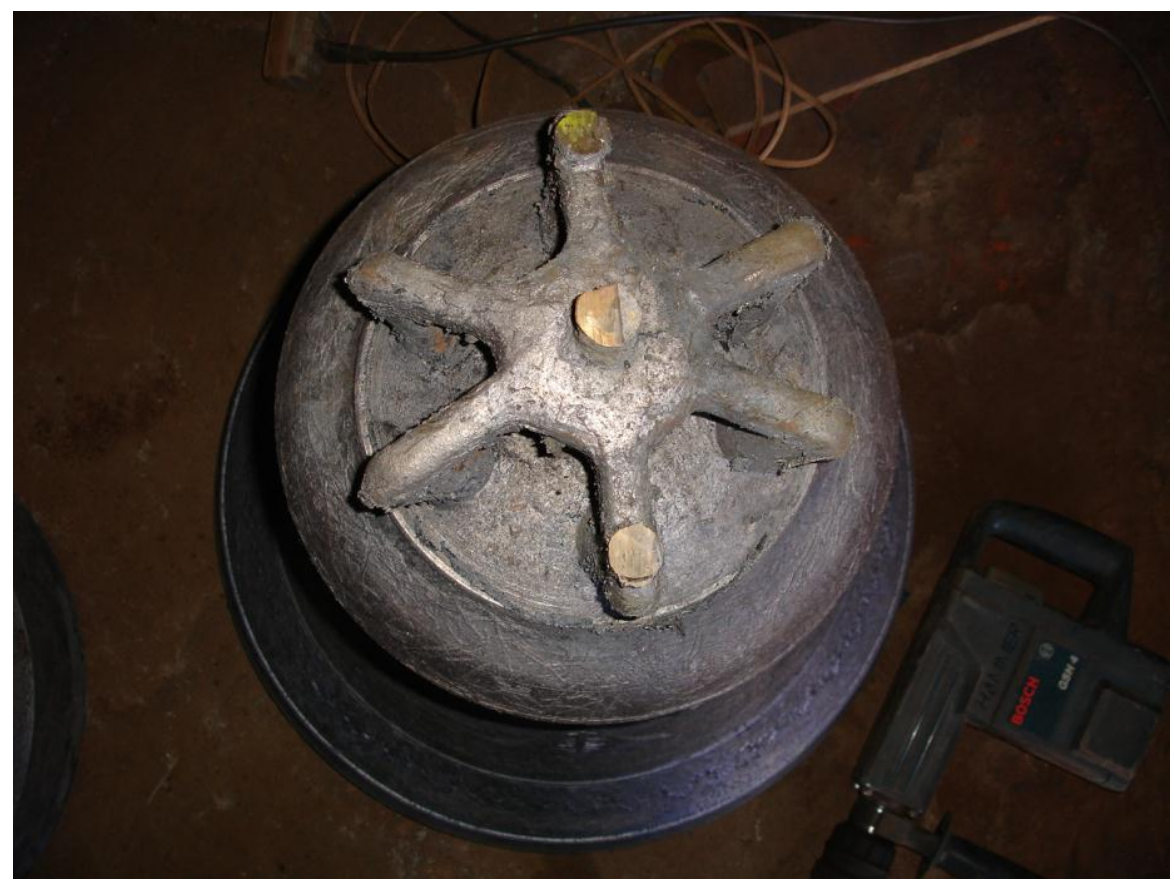

Figuras 103. Sinos com rebarbas nas manilhas.

Fonte: fotografadas na visita realizada em 20/07/201

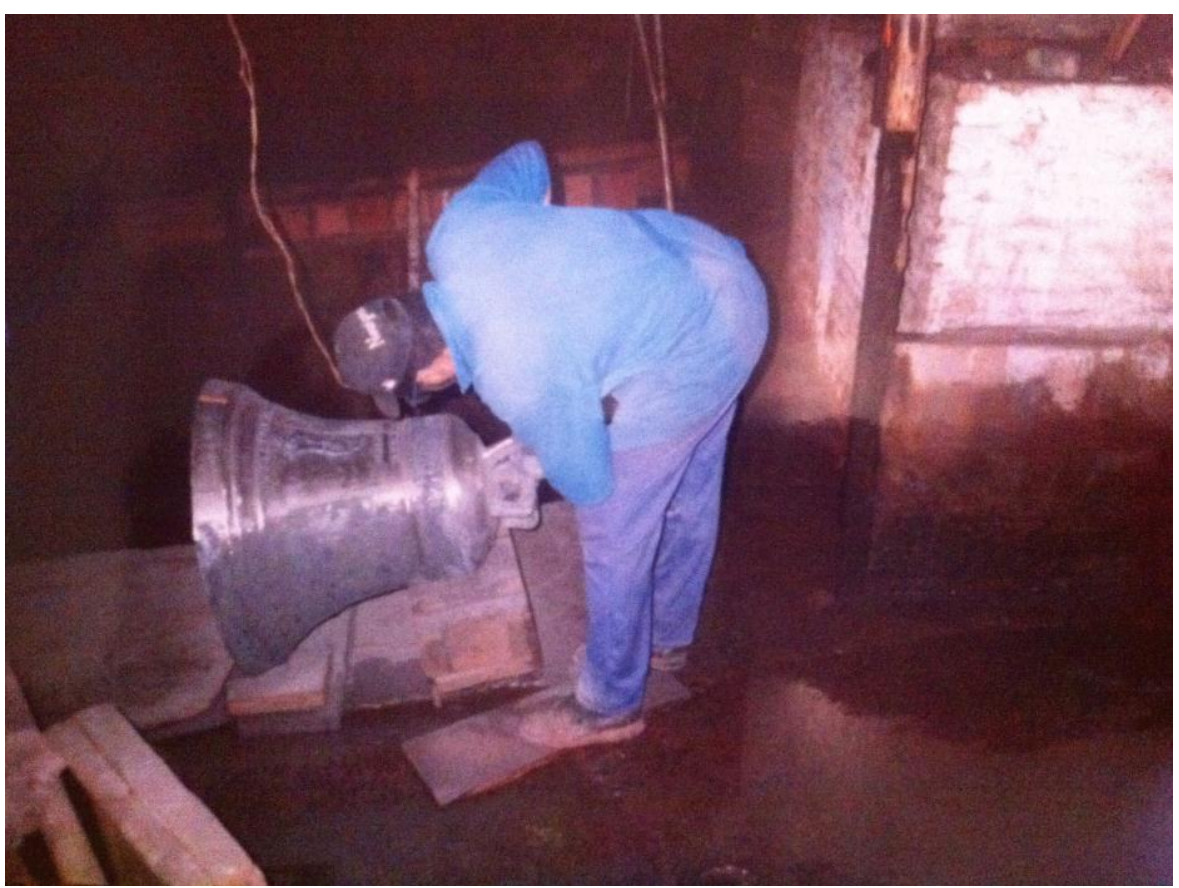

Figura104. Processo de polimento do sino

Fonte: fotografia do acervo da FASU 


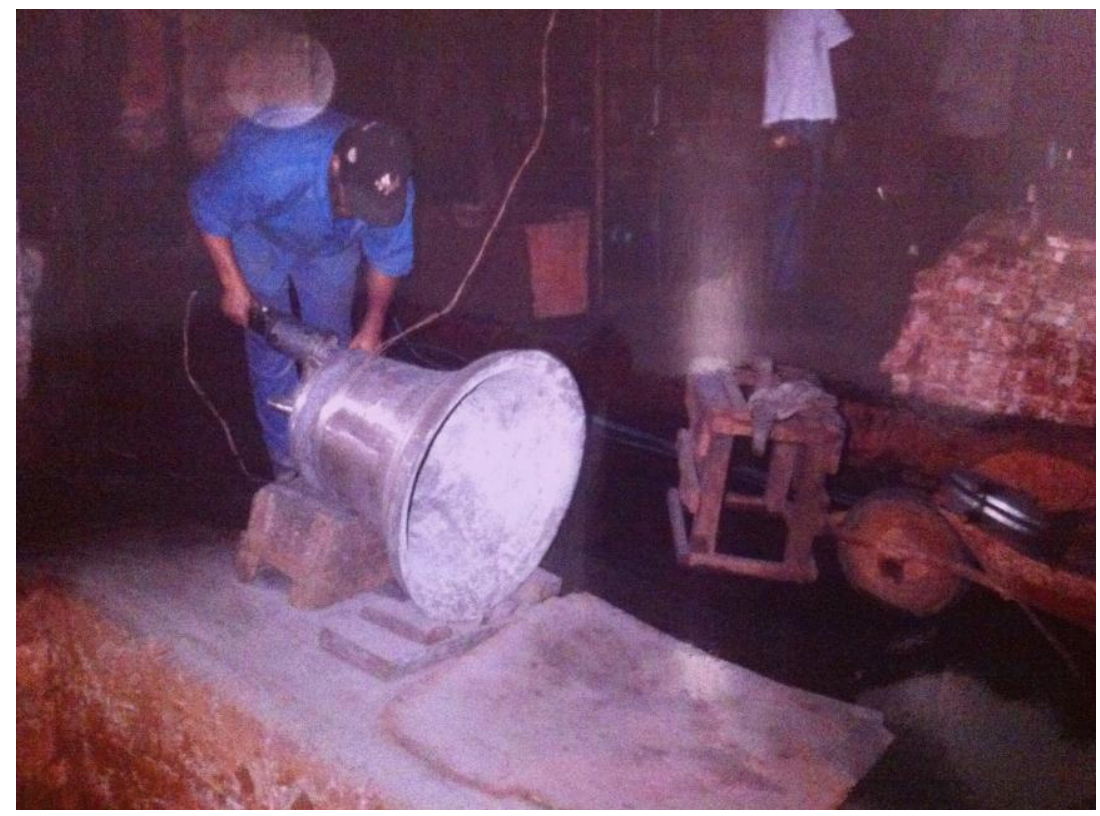

Figura 105. Polimento do sino em bronze. Fonte: fotografia do acervo da FASU

O Sr. Donizete relatou que, anos atrás, um sino era fabricado em seis meses; não havia pressa, por isso era possível aguardar mais encomendas e fazer oito a doze sinos ao mesmo tempo. Hoje, ele tem que fazer no prazo de um mês, o que impossibilita esperar o acúmulo de pedidos e fazer mais de um sino ao mesmo tempo. Comentou também que o número de pedidos tem diminuído bastante. Muitas igrejas utilizam a gravação das badaladas dos sinos.

Tentaram acabar com o sino, produzindo aparelhos sonoros, esses aparelhos que imitam o sino. Mas nada, não tem jeito de superar porque a pessoa que gosta, gosta do sino. Ele sendo caro ou não, a pessoa gosta do sino. Teve vez que, dormindo em casa paroquial ou em um hotelzinho mais próximo do servico, próximo da igreja, então, quando termina o serviço, você fala: um pedaço de mim vai fícando. E dá uma comoção danada. Quando é cedinho também, quando é de manhã que a gente escuta, de tão alegre é 
triste porque é alegre para a gente ouvir, mas é triste porque está dando um sinal. Há sinos seus em diferentes localidades do país, conforme mostram as Figuras 106 a 108.

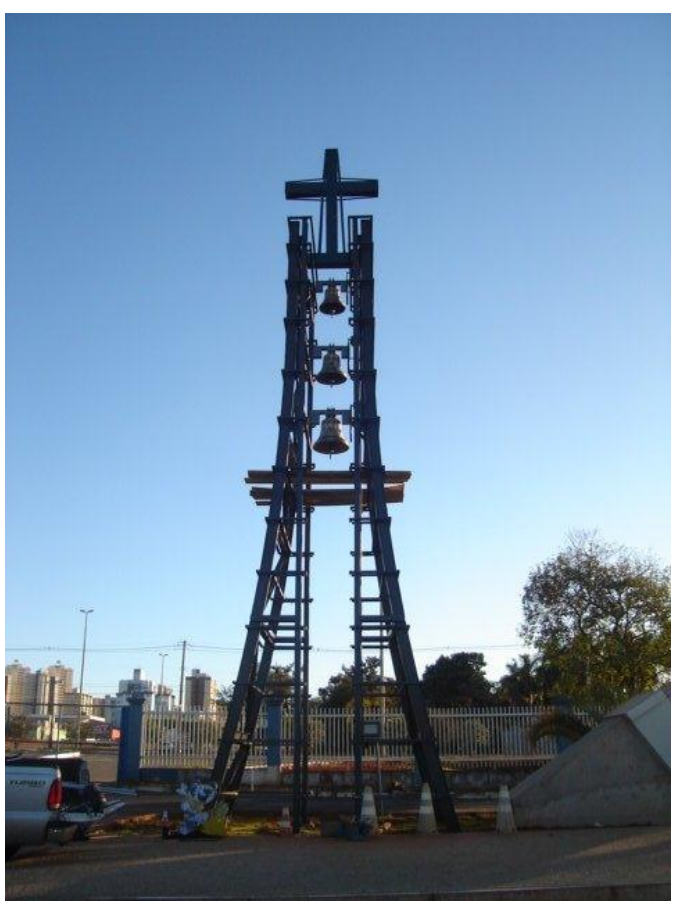

Figura106. Sinos de 205kg (dó), 140 kg (ré) e 100 kg (mi) localizadas na Paróquia Imaculada Coração de Maria, em Brasília DF.

Fonte: fotografia do acervo da FASU

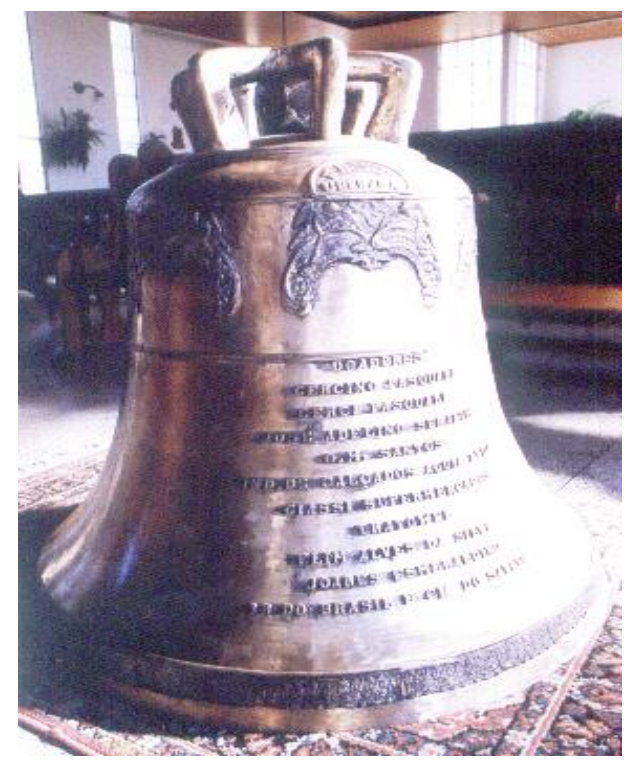

Figura 107. Sino de $410 \mathrm{~kg}$ (lá bemol) localizado na Igreja Sagrada Família, em Araranguá - SC. Fonte: fotografia do acervo da FASU 


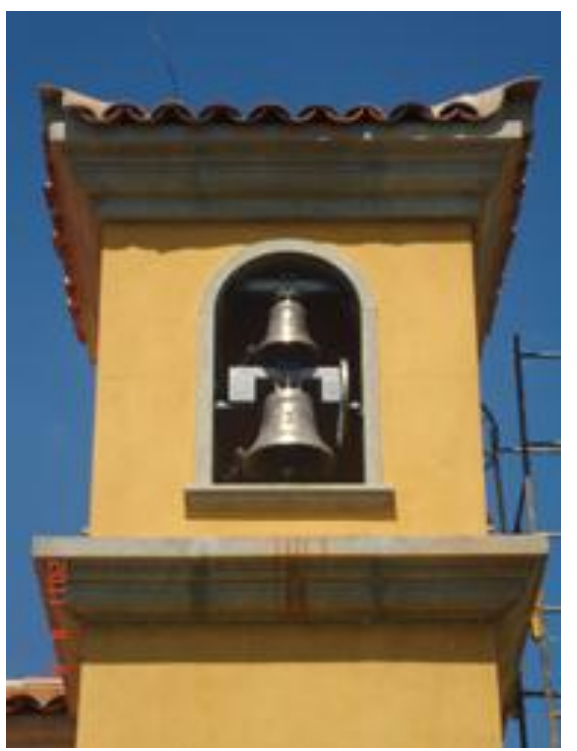

Figura108. Sinos de $85 \mathrm{~kg}$ (fá) e $60 \mathrm{~kg}$ (sol), localizados em Souzas - SP. Fonte: fotografia do acervo da FASU

O filho mais velho do Sr. Donizete e seu sobrinho trabalham com ele. Dão continuidade ao ofício de fabricação de sinos. Com base em seus cursos tecnológicos de mecânica e mecatrônica, criaram um sistema de automação de sino, chamado Controlador Lógico Programável/CLP (ver Figura 109).

$\mathcal{O}$ sistema com o martelo é eletrónico, para tocar música. Um martelo num sino, o outro em outro, dá um carrithão de 7 notas, de 5 já permite música, de 6 ou 7.

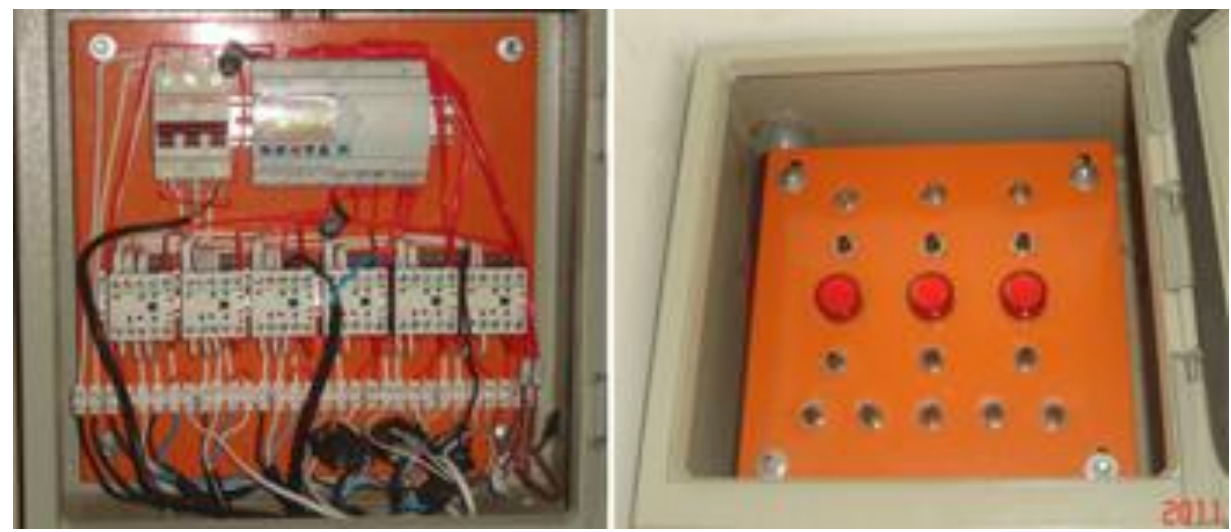

Figura109. Sistema de automação para melodias. Fonte: fotografia do acervo da FASU 
Antes de explicar o CLP, o sobrinho informou da possibilidade de instalar um pequeno motor que realiza o movimento do sino para as badaladas.

Para automatizar, em vez da corda para badalar o sino, modifica o cabecote e instala um motorzinho. Os sinos badalam conforme a hora programada ou por botão. Com o CLP, programa-se a hora que o sino vaí ser acionado. No caso da música, é preciso um toque sincronizado. É uma batida em cada sino porque cada um tem uma nota musical especifica. As notas musicais são convertidas em linguagem de programaça eletrónica. A batida, o tempo da batida em cada sino, dá a melodia final. O CLP pode ser acionado em horas programáveis ou vía botão e a música é ativada. Quando tem que ser feita alguma alteração, se faz a alteração in loco mesmo, no local mesmo; a gente programa, dimensiona, pré-dimensiona e no local faz a devida programação. As vezes, acontece do sino bater num lado só e, então, a gente controla o tempo dele. $O$ pulso on/off que ele vai mandar para o sino ir e outro pulso para o sino vir, ele tem que bater nos dois lados de maneira sincronizada. Quando isso não acontece, tem que ter alguma alteração no momento mesmo. Antigamente, algumas empresas colocavam dispositivos de fim de curso, sensores que controlam o pulso do sino ir e vir e o pulso que limita a altura dele. Tinha um sensor que limitava a altura dele; chegow nessa altura, corta o pulso do motor para o sino não ir atém disso. O nosso sino tem que ir ao máximo $90^{\circ}$ para ambos os lados. Esse era o controte eletromecânico e possivelmente aconteceram falhas constantes do 
sino não acionar porque, se o fim de curso não atuar, o sino sai do toque dele porque tem um limitador que é a corrente, como pode ser visto na Figura 109. Tem o dente dessa coroa do motor que limita a traça para o sino balancar e, quando sai fora dessa corrente, o sino não toca mais. A peca do CLP que bate no sino chama-se martelo eletromecânico. A bobina vai energizá-lo. Ele é um eletroímã. O CLP, quando dá o pulso, a bobina é energizada e ela puxa o ferro es, ao puxá-lo, ela bate na borda do sino para tocar, fazer a melodia. Isso envolve a matemática, envolve a linguagem de programação eletrônica, são váríos conceitos em um só. Então, integra-se a área de mecânica, eletrônica e elétríca também. E até muisica entra nesse conceito.

Por meio do CLP, foi desenvolvida uma série de melodias, a Ave Maria de Schubert e a de Gounod, a Nona Sinfonia de Bethoven, hinos sacros - Nossa Senhora Aparecida e Ave de Lourdes - músicas populares como Carruagem de fogo, Asa Branca, Caçador de mim, entre outras melodias adaptáveis com o som dos sinos.

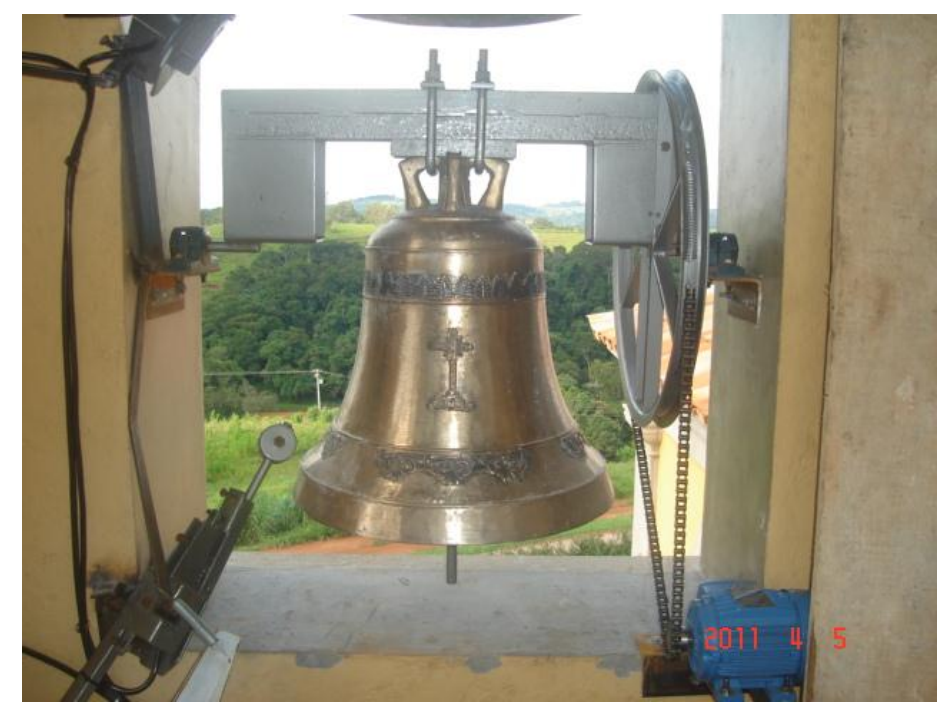

Figura110. Sinos de $85 \mathrm{~kg}$ (fá) e $60 \mathrm{~kg}$ (sol), localizados em Souzas - SP. Fonte: fotografia do acervo da FASU 
Em uma segunda visita, o Sr. Donizete conversou a respeito do conhecimento do sino não se perder, poder ser ensinado na escola. Ele sugeriu que fizesse parte do currículo, não precisando ser uma disciplina, mas que o sino fosse apresentado e explicado às crianças. Assim, ele explana:

Tenho escutado muito e é pelo Brasit inteiro que a gente vai, né. Então, tem crianca, tem jovem, tem adulto e tem velho também... tem uns que às vezes faz uma pergunta: Isso aí é de ferro? Não, isso aqui é bronze. Mas que diferenca tem o ferro com o bronze?[...] quando é uma criança não chegow lá, mas as de hoje, conforme o tamanho, já sabe muito. Agora, quando a gente pega uma pessoa ídosa, á quer dizer que é escolaridade, né?! $O$ que é o sino? É uma peça. Mas que peca é essa? É uma peç sonora. E essa peca sonora, o que é? Ela faz parte de... dependendo do que você entende daquele tom... você pode por muisica, uma informacaio. Porque dependendo do hugar, tem essa cultura, do toque do sino representar tal coisa, o toque do sino, dependendo do tipo, o toque tá informando que nasceu, morrew ou vem tempestade; conforme o hugar, tem isso. Então, deveria se explicar isso para a pessoa não poder sair tão igual. Uns.. que vem aqui e vê a gente trabalhando ati e já vê um sino pronto, mas é de barro? e faz esse barulho? Não tem nada a ver, né? 
Percebe-se em sua fala o interesse que as pessoas conheçam o sino, de que ele é feito e como é sua fabricação. Isso fica marcante quando pessoas adultas confundem o metal ferro com o bronze, acreditando ser a mesma coisa.

A descrição do processo de fabricação de um sino explicita a complexidade dessa atividade. São vários procedimentos articulados que devem ser realizados com precisão, pois, por um pequeno detalhe, o resultado pode ser danoso e todo o trabalho se perde. Se a espessura e consistência da argila forem alteradas, a espessura do sino em bronze também será alterada e, por consequência, influenciará a sua nota musical. O conhecimento e a técnica do Sr. Donizete foram desenvolvidos juntos a um mestre do ofício e pela experiência ao longo dos anos, no trabalho diário e na avaliação dos resultados. Ao olhar para um sino pronto, o Sr. Donizete é capaz de identificar se ocorreu alguma falha e em que momento. Foi possível perceber que se trata de uma hibridização de conhecimentos provenientes da experiência direta e de várias ciências. Esse conhecimento envolve inúmeros enlaces conceituais, operações e procedimentos.

Com o intuito de explicitar tal hibridização, foram elaboradas células de sistemas de organização conceitual com conceitos logicamente coordenados, subordinados e supraordenados, ainda que os atributos dos critérios, para tanto, sejam especificados pelo sineiro em relação ao seu ofício e não em relação ao sistema teórico da ciência a que pertencem os conceitos.

A Figura 111 caracteriza uma célula de sistema conceitual. Apresenta relações de coordenação entre os metais (cobre, estanho níquel e zinco), de subordinação em relação à especificação do metal ligado, o bronze - articulando-o ao atributo da liga pelo critério de resistência, atributo observável - e de supraordenação em relação ao conceito "metais". 


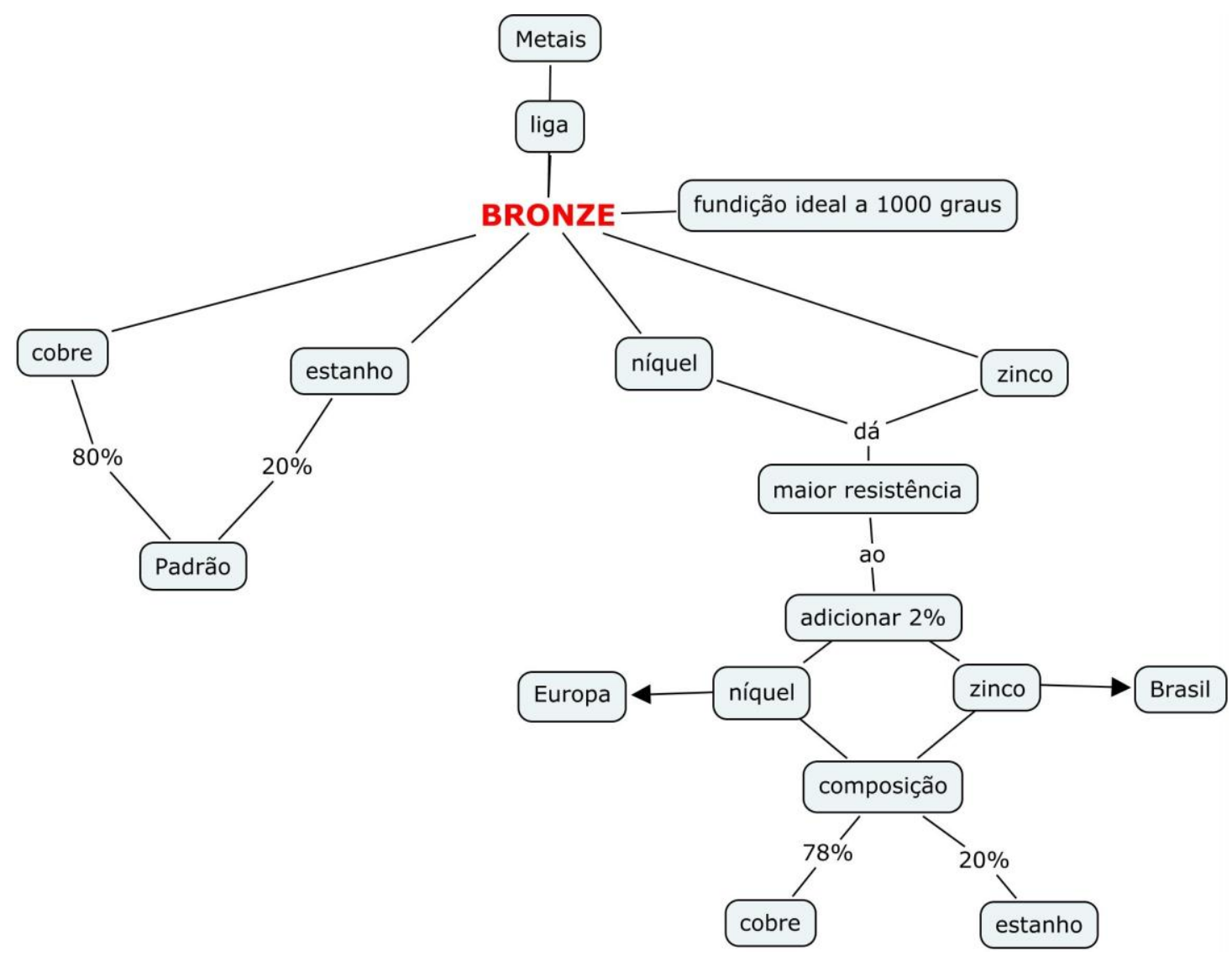

Figura 111. Célula de mapa conceitual do sineiro referente à liga de metais - bronze.

Contudo, não pode ser considerado um sistema conceitual da ciência Química, pois não demonstra o critério de universalidade próprio da ciência. Apesar disso, é um sistema conceitual que não apresenta equívocos do ponto de vista científico.

As Figuras 112 e 113 retratam células de sistema conceitual que explicitam atributos operacionais e relações de coordenação e subordinação. $\mathrm{Na}$ Figura 112, destaca-se a função dos conceitos coordenados e subordinados que constituem o luto e na Figura 113, observam-se as propriedades dos conceitos coordenados e subordinados que constituem os dois tipos de argila fabricada. 


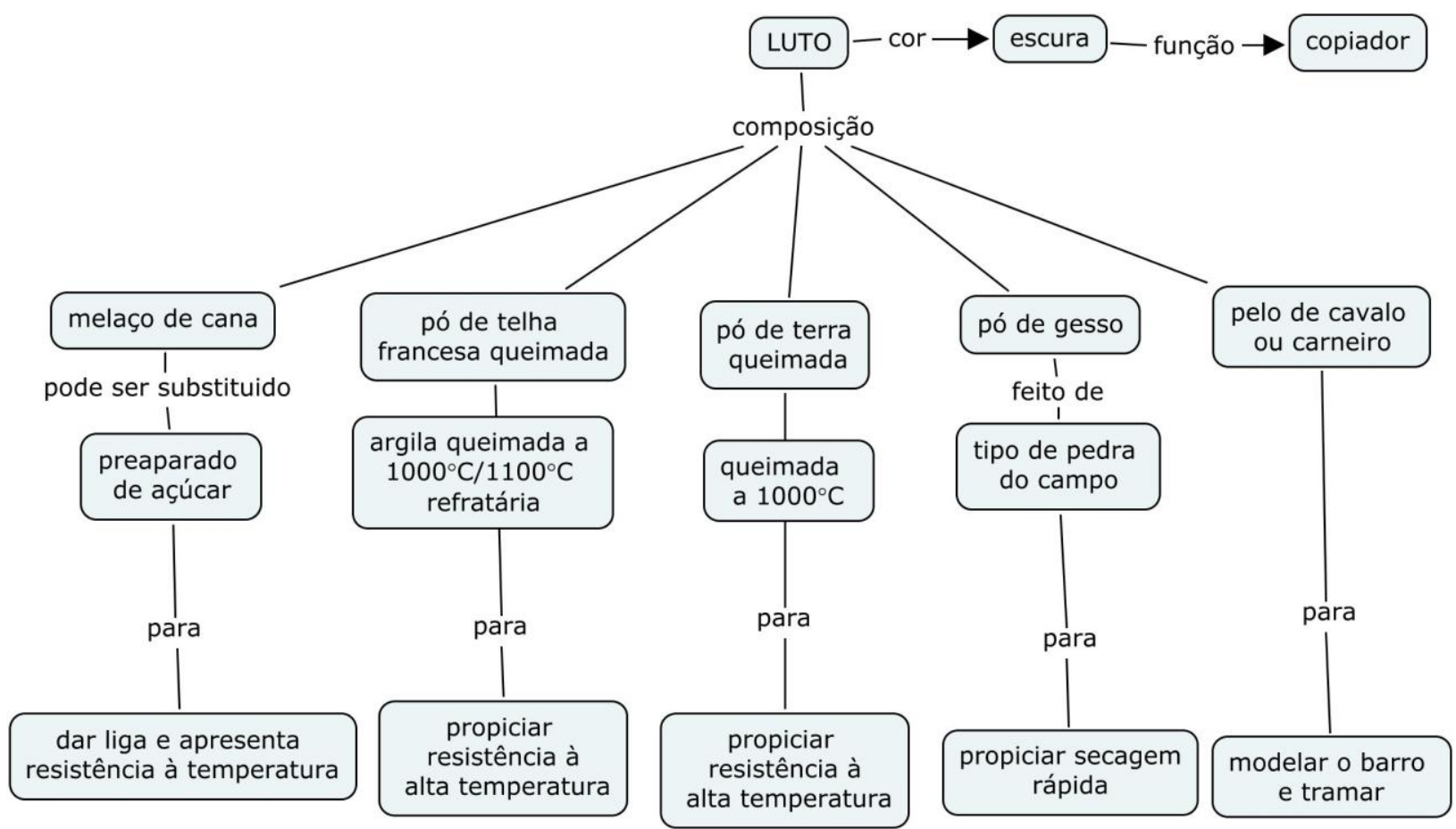

Figura 112. Célula de mapa conceitual do sineiro - luto, barro copiador. 


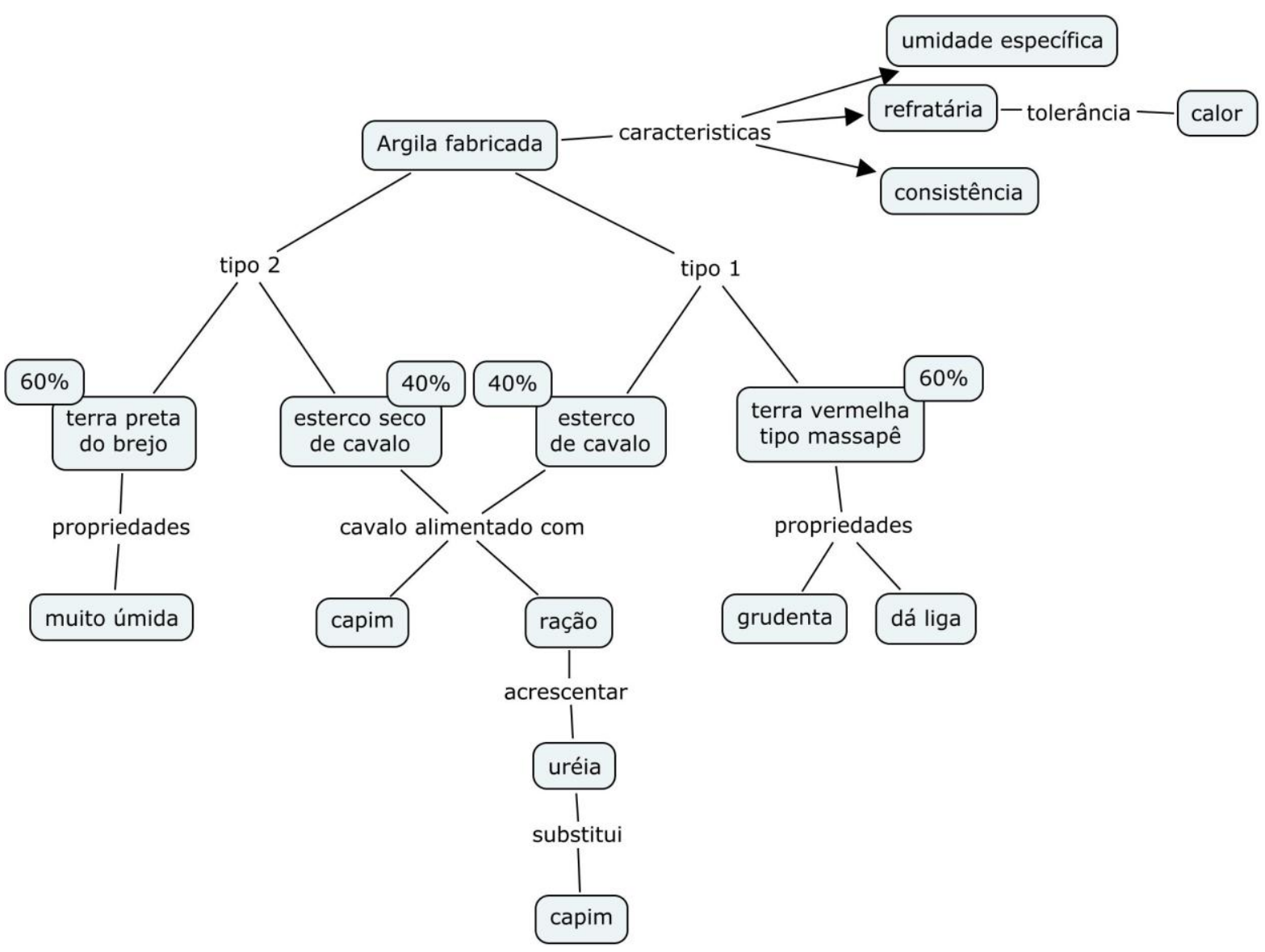

Figura 113. Célula de mapa conceitual do sineiro - argila fabricada.

Em ambas as atividades, a do sineiro e a do ourives, constata-se hibridização de conhecimentos. É possível verificar, também, formações de nexos que se estabelecem entre o pensamento e a ação. 


\section{ÚLTIMAS PALAVRAS}

$\mathrm{Na}$ sociedade contemporânea, de um modo geral, e no campo da Educação e da Psicologia, de um modo particular, é bastante difundida e arraigada a ideia de que o conhecimento científico é diferente do conhecimento que se forja nas atividades do cotidiano, e superior a ele. Acredita-se que para ter acesso ao conhecimento científico é preciso ingressar na escola. Esta é uma das instituições do Estado que cumpre a função de controle e tutela social do processo de ensinoaprendizagem e, por sua suposta excelência, possibilitaria 0 acesso a esse conhecimento superior.

Neste trabalho é examinada essa distinção. Para tal, foram discutidas as ideias exemplares de Vigotski a respeito desse assunto, posto que é um dos poucos teóricos da Psicologia, se não o único, que elaborou um trabalho sistemático sobre essa distinção. Ele chama os conceitos científicos de verdadeiros e vê-os como um dos tipos dos conceitos puros; a estes, opõe-se outro tipo de conceito, o cotidiano. Ele procurou mostrar que os dois conceitos se distinguem pela sua gênese - os cotidianos originam-se na experiência do dia a dia e os científicos, na instrução escolar -, pela sua estrutura - os cotidianos organizam-se de forma assistemática enquanto que os científicos, em sistemas hierárquicos de relações conceituais -, e pela sua função - os cotidianos propiciam o enraizamento do indivíduo na vida e os científicos, a formação da consciência reflexiva. Apesar da distinção dos dois tipos de conceitos, afirma que ambos estão em contínua interação e desenvolvem-se em influência mútua, e que os conceitos científicos ancoram-se nos cotidianos. Para ele, por possibilitar o acesso ao conhecimento científico, a escola é o portal da consciência.

Contudo, uma questão requereu uma análise aprofundada: seria o conhecimento apresentado aos estudantes na escola conhecimento científico propriamente dito? Verificou-se que, nessa instituição, o conhecimento passa pela transposição didática para que possa ser compreendido pelos estudantes e aceito como verdade. Procurou-se, então, esclarecer qual seria a natureza do conhecimento escolar e que tipo de pensamento conceitual ele forjaria. Com base 
em vários autores, buscou-se demonstrar que o conceito escolar com que os estudantes operam é diferente daquele com que os cientistas operam. O conhecimento escolar tem um caráter híbrido decorrente da relação que ocorre entre o que provém da ciência e o que os professores e estudantes trazem de suas próprias vivências cotidianas.

Em um segundo momento, procurou-se esclarecer o que vem a ser o cotidiano e a natureza da atividade cotidiana, de forma a elucidar que esta não é feita somente de rotinas repetitivas, mas de processos das mais diferentes naturezas. Há muita confusão entre os autores que estudam o cotidiano. No presente trabalho, foram analisadas duas concepções distintas a respeito do que seja cotidiano. Uma é a visão helleriana, que entende que o pensar cotidiano é constituído de ideias fragmentadas e juízos probabilísticos, sendo guiado por estereótipos. Para Heller, somente a ciência e a arte são capazes de libertar o homem das entranhas da cotidianidade. A outra é a visão lefebvreriana, que reconhece os processos repetitivos e automáticos que estão presentes na cotidianidade, mas ressalta o caráter de criação e inovação que fundam a vida cotidiana. Com base nas ideias lefebvrerianas, foi possível demonstrar que o caráter repetitivo e criador se fazem presentes tanto na ciência, na arte, como nas ações do dia a dia.

Em um terceiro momento, discutiu-se qual seria a natureza do conhecimento científico: se ele é um conhecimento que está fora do cotidiano ou se realiza-se no próprio cotidiano, mas tem sua estrutura própria. Ao fazer esse exame, verificou-se que a ciência não se desenvolve fora do cotidiano, não é fruto do transcendente. Ela está imersa no mundo, não é um conhecimento puro. A atividade científica também apresenta um caráter híbrido, pois decorre daquilo que é próprio da atividade científica na sua relação com as vivências dos próprios cientistas, que também são cotidianas. Em suma, o conhecimento científico, assim como o conhecimento escolar, tem um caráter também cotidiano. Há uma variedade de conhecimentos, de atividades e de modos de hibridização. O hibridismo acontece porque a vivência é constituinte do próprio pensamento e, portanto, está presente no conhecimento, pois ele é criação humana, que tem uma relação particular com o mundo. Por isso, a ciência não é pura, no sentido dado por Vigostki.

Em um quarto momento, foi realizada uma descrição e análise dos modos de organização do pensamento conceitual de duas atividades, a do artesão ourives 
e a do sineiro. Com esse exame detido, foi possível verificar que o pensamento deles contém células diversas de pensamento conceitual, dentre elas: células de operação por conceitos provenientes da ciência e células de operação por conceitos provenientes da própria atividade. Elas têm um caráter funcional ou operacional e são conhecimentos híbridos. Ou seja, são modos diferentes de operar o pensamento conceitual, cada um com a sua particularidade decorrente da atividade em que o pensamento ocorre. Assim, vê-se que não é possível afirmar que há um tipo de pensamento, chamado "conceito científico", que se diferencia de outro tipo, denominado "conceito cotidiano". Isso se deve ao fato de que todas as atividades podem envolver conceitos provenientes da ciência, mas abarcam, também, outros conceitos que são oriundos das vivências daquele que realiza a atividade e da própria atividade. Assim, na realidade, no presente trabalho foram apontados fortes indícios de que os conhecimentos são híbridos e de que há uma infinidade de modos de conhecimento e de modos de operar o pensamento por conceito. Os conhecimentos são distintos uns dos outros, mas o que os diferencia é o tipo de atividade, a própria estrutura da atividade e o modo como é realizada.

Verifica-se, então, que o objetivo do presente trabalho, que consistiu no exame crítico da distinção entre conceitos cotidianos e científicos e da supremacia conferida a estes últimos, foi cumprido. Os resultados desse exame, contudo, trazem implicações que merecem ser estudadas. Quais seriam elas?

Um primeiro tipo de implicação seria para o próprio ensino escolar de conceitos. A grande maioria dos professores, dos educadores, dos pedagogos e dos psicólogos que trabalham na área da educação acredita que a escola promove a formação do pensamento científico. Essa ideia, contudo, não parece válida pelo que se viu. O conhecimento difundido na escola tem um caráter tão híbrido quanto se pode verificar em outras variadas atividades do homem. Assim, não há como justificar o fato de a escola ter a primazia e a hegemonia para o ensino de conceitos supostamente científicos.

A segunda implicação incide sobre a crença bastante difundida de que, para chegar ao conhecimento científico, é preciso contextualizá-lo, relacioná-lo a fatos do dia a dia do estudante. Ou seja, para que o estudante aprenda a pensar cientificamente, o professor deve partir do cotidiano dele e levá-lo, por meio disso, a um pensamento superior mais nobre, que implica a transformação do pensamento cotidiano em científico. Essa prática carece de fundamentos, em primeiro lugar 
porque a atividade escolar é também cotidiana. Além disso, defender a ideia de que para ocorrer o aprendizado dos conceitos científicos é preciso relacioná-los ao que é supostamente chamado de conhecimento cotidiano não tem atendido plenamente aos objetivos do ensino. Como já foi mencionado, definir um conceito não equivale a pensar com esse conceito. A qualidade do ensino dos chamados conceitos científicos, na escola, não pode, portanto, estar atrelada a esse tipo de estratégia pedagógica porque é um tipo de solução falsa e equivocada. Finalmente, é passada a impressão de que há continuidade dos conhecimentos e que, ao atingir o status de científico, alcançou-se o apogeu. Todavia, o que os estudantes aprendem na escola não é propriamente ciência, mas conhecimento escolar. Se o ensino escolar está fracassando e os estudantes não estão aprendendo de modo satisfatório o que se pretende, o que precisa ser feito não é a adoção de estratégias pedagógicas desse tipo, mas o exame cuidadoso e detido da própria estrutura da atividade escolar. Assim procedendo, talvez seja possível compreender-se porque, de modo geral, os estudantes parecem não perceber o sentido do ensino e da aprendizagem escolar.

Ir à escola faz parte do cotidiano. Entretanto, a atividade escolar, ainda que cotidiana, pode carecer de sentido. Este somente pode encontrar-se nela própria e não em outras atividades do cotidiano.

Há, ainda, uma terceira implicação importante que incide sobre a própria teoria educacional e a teoria psicológica a respeito do desenvolvimento do pensamento. Vigotski (1997) assevera que a escola é o portal da consciência. Em outras palavras, para ele, o acesso ao conhecimento científico, na escola, promove o desenvolvimento do pensamento por conceitos científicos e a formação da consciência reflexiva, isto é, da condução e discernimento voluntário do ato de pensar. Ainda que, no presente trabalho, não se tenha tratado da questão da formação e do desenvolvimento da consciência reflexiva, são possíveis algumas conjecturas a esse respeito. Por exemplo, pode-se supor que a condução voluntária autônoma do ato de pensar possa desenvolver-se não somente na atividade científica, estritamente falando, mas em variadas e diferentes atividades. Assim sendo, presume-se que haja uma variedade de modalidades de consciência reflexiva e não somente um tipo, como Vigotski afirmava em sua obra Pensamiento y habla (2007).

Pensar na possibilidade de formação e de desenvolvimento da consciência reflexiva em atividades diversas, entretanto, não é o mesmo que admitir 
que todas as atividades humanas propiciem as condições que possibilitem 0 desenvolvimento do pensar autônomo. Será que, no modo industrial de atividade de fabricação, por exemplo, é possível o desenvolvimento da consciência reflexiva? Talvez, numa atividade altamente repetitiva que não admita possibilidades de criação, como a fabricação em série, em que o funcionário atua na linha de montagem, as chances de aparecer uma organização de pensamento dessa natureza sejam muito pequenas. Os resultados do exame aqui realizado, todavia, não permitem qualquer afirmação categórica a esse respeito.

Seja como for, o que se pode concluir, com alguma segurança, diz respeito à necessidade de examinar cada atividade em particular. $\mathrm{E}$, mais do que isso, é preciso levar em conta, para cada atividade, quem a realiza e como o faz, pois, sendo a vivência uma particularidade, não há possibilidades de tratar as atividades de modo generalizado. Vigotski tratou do conceito de vivência em sua obra e compreende-a como aquilo que acontece entre o homem e o mundo. Assim, a vivência não diz respeito nem ao mundo nem ao homem, mas constitui-se numa unidade da relação homem e mundo. Daí porque ela é de caráter estritamente pessoal e particular. Toda pessoa imprime suas próprias vivências em qualquer atividade que realiza. Então, para que se possa saber se uma determinada atividade possibilita a formação da consciência reflexiva, é preciso conhecer quem é a pessoa que a realiza e o modo idiossincrático de fazê-lo.

Destarte, pode-se dizer que a ideia de que os conceitos podem ser divididos em cotidianos e científicos assenta-se em bases equivocadas porque parte da ideia de que a ciência é uma atividade que suspende o homem do cotidiano. Trata-se de um equívoco, porque o fazer ciência implica estar completamente imerso no mundo. Conforme aponta Arendt (2001), fazer ciência é atividade do Homo faber, tanto quanto o é a arte e o fabricar sinos. Uma questão que merece discussão é o fato de Heller parecer admitir que o pensar cientificamente tem o mesmo estatuto do filosofar. Este, sim, para Arendt (1978a), implica isolamento do mundo, mas, mesmo assim, deve partir do próprio mundo e a ele retornar.

Por fim, o encontro com esses mestres de ofício possibilitou compreender, à luz do pensamento arendtiano, que fazer ciência implica estar completamente imerso no mundo, bem como verificar que eles se apropriaram do conhecimento científico conforme as exigências de suas atividades. A ciência não pertence ao cientista, uma vez que o conhecimento produzido pelo pesquisador passa a ser de 
todos, assim como acontece com a obra de arte e a obra musical. A ciência parte do mundo e nele permanece de forma hibridizada. As pessoas apropriam-se à sua maneira do conhecimento científico movidas pela necessidade que está presente na atividade que realizam.

A ideia de que a ciência liberta o homem das entranhas da cotidianidade é pura ilusão. A ciência nada mais é que um modo refinado do "raciocínio de senso comum" (ARENDT, 1978a, p.75). A atitude de subserviência ao conhecimento científico promove o afastamento do homem do senso de comunidade. Esse distanciamento, por sua vez, conduz à insanidade. Ou seja, ao se desconsiderar a existência de uma diversidade de conhecimentos presentes na vida cotidiana pela devoção à ciência, e ao se submeter aos valores de uma sociedade escolarizada, são dadas as condições para a espetacularização insana da vida. 


\section{REFERÊNCIAS}

ANDRADE,A.T. Resgatando a Química nos saberes populares: a profissão de ourives e o processo de eletroposição do ouro. 2008.76p. Monografia de graduação, Instituto de Química, Universidade de Brasília. Brasília, 2008.

ARAÚJO, D. X. O conceito de substância em química aprendido por alunos do ensino médio. 1992. 312p. Dissertação de mestrado, Departamento de Química, Universidade de Brasília. 1992

ARENDT, H. A condição humana. Tradução de Roberto Raposo. Rio de Janeiro: Forense Universitária, 2009a.

. Entre o passado e o futuro. Tradução de Mauro W. Barbosa. São Paulo: Perspectiva, 2009b.

A vida do Espírito. vol.1-Pensar.Lisboa: Instituto Piaget,1978a.

A vida do Espírito. vol.2- Querer. Lisboa: Instituto Piaget,1978b.

BAKHTIN, M.M. A cultura popular na Idade Média e no Renascimento: o contexto de François Rabelais. Tradução de Yara Frateschi Vieira. São Paulo: Hucitec; Brasilia, Editora UnB, 2008.

BARTHOLO, R. Os Labirintos do Silêncio- Cosmovisão e Tecnologia na Modernidade. Rio de Janeiro: Marco Zero/Coppe/UFRJ, 1986.

A dor do fausto: ensaios filosóficos. Rio de Janeiro: Revan,1992.

Alteridade e preconceito. In Tunes,E. e Bartholo,R.(orgs.) Nos Limites da Ação: Preconceito, Inclusão e Deficiência. São Carlos, UFSCAR,2007.

BONIN, W. F. Diccionario de los grandes psicólogos. De las ciências del espíritu a lãs ciências de La conducta. Fondo de Cultura econômica, S.A., 1991.

BOSI,E. O tempo vivo da memória: ensaios de psicologia social. São Paulo: Ateliê, 2003.

CARUSO,M. Introducción Histórica - Em El jardin de los marxismos que se bifurcan. In VIGOTSKI,L. Pensamiento y habla. Buenos Aires: Colihue, 2007.

CARVALHO, M.C.B.; NETTO, J.P. Cotidiano; conhecimento e crítica. São Paulo: Cortez, 2010. 
CAVALCANTE, A.V. O Preconceito da Deficiência no processo de Inclusão Escolar. 2004. 147p. Dissertação de Mestrado. Faculdade de Educação, Universidade de Brasília, 2004.

CERTEAU, M. A invenção do cotidiano: 1.Artes de fazer. Tradução de Ephraim Ferreira Alves. Petrópolis: Vozes, 2008.

; GIARD, L.; MAYOL, P. A invenção do cotidiano: 2.morar,cozinhar. Tradução de Ephraim Ferreira Alves,Lúcia Endlich Orth. Petrópolis: Vozes, 1996.

DOMINGUINI,L. A transposição didática como intermediadora entre o conhecimento científico e o conhecimento escolar.Revista Eletrônica de Ciências da Educação. Campo Largo, v. 7, n. 2, nov. 2008.

DUARTE, N. Educação Escolar, teoria do cotidiano e a escola de Vigotski. Campinas: Autores Associados, 2007.

FLUSSER, V. Filosofia da Caixa Preta - Ensaios para uma futura filosofia da fotografia. Rio de Janeiro: Sinergia Relume Dumará, 2009.

A Crise das Ciências, a proximidade e o desejável. Revista Brasileira de Filosofia. São Paulo, v.30,fascículo 113, jan/fev/mar, 1979.

GOLA, E. A joia: história e design. São Paulo: Senac são Paulo, 2008.

GONZÁLEZ,A.A. Nota do tradutor, $\mathrm{n}^{\circ}$ 47. In VIGOTSKI,L. Pensamiento y habla. Buenos Aires: Colihue, 2007.

GOULD,S.J. A Falsa medida do Homem.Tradução de Valter Lellis Siqueira. São Paulo: Martins Fontes, 2003.

GUERREIRO RAMOS, A. A Nova Ciência das Organizações: Uma Reconceituação da Riqueza das Nações. Tradutora Mary Cardoso. Rio de Janeiro: Fundação Getúlio Vargas, 1981.

GUIMARÃES,G.T.D. Historiografia da cotidianidade: labirintos do discurso. Porto Alegre: EDIPUCRS, 2000.

HELLER, A. O Cotidiano e a História. Tradução de Carlos Nelson Coutinho. São Paulo: Paz e Terra, 2004.

Sociologia de la vida cotidiana. Tradução de J.F. Yvars, E.Pérez Nadal. Barcelona: Península, 1994.

ILLICH, I. Sociedade sem escolas. Tradução de Lúcia Mathilde Endlich Orth. Petrópolis: Paz e Terra, 1986.

IVANOVSKI, V.N. Metodologuítcheskoe vvedienie $\mathbf{v}$ nauku i filossofiu (Introdução metodológica à ciência e à filosofia). Minsk, 1923. 
KASANIN,J.;HANFMANN, E. Conceptual Thinking in Schizophrenia. Nova York: NMDP, 1942.

KOSIK, K. Dialética do concreto. Tradução de Célia Neves; Alderico Toríbio.Rio de Janeiro: Paz e Terra, 2002.

KOZULIN,A. La psicologia de Vygotski: Biografía de unas ideas. Tradução de Juan Carlos Gómes Crespo. Madri: Alianza Editorial, 1994.

LEFEBVRE, H. A vida cotidiana no mundo moderno. Tradução de Alcides João de Barros.São Paulo: Ática, 1991. 1947.

.Critique de La Vie Quotidienne (Introduction). Paris: Bernard Grasset,

LEONTIEV, A. Actividad Conciencia Personalidad. Tradução de Librada Leyva Soler; Rosário Bilbao Crespo; Jorge C. Potrony Garcia. Havana: Pueblo y Educación, 1983.

LOPES, A.R.C. Conhecimento Escolar: ciência e cotidiano. Rio de Janeiro: EdUERJ,1999.

LURIA, A.R. Curso de Psicologia Geral,vol.IV. Tradução de Paulo Bezerra. Rio de Janeiro: Civilização Brasileira, 1979.

Desenvolvimento Cognitivo: seus fundamentos culturais e sociais. Tradução de Fernando Limongeli Gurgueira. São Paulo: Ícone, 1990.

MARTINS, J.S. A Sociabilidade do homem simples: cotidiano e história na modernidade anômala. São Paulo: Contexto, 2010.

MARX, K. Contribuição à crítica da economia política. Tradução de Maria Helena Barreiro Alves. São Paulo: Martins Fontes, 2011.

Ökonomische Manuskripte - Grundrissen der Kritik der politischen

Ökonomie. (Manuscritos de Economia - Fundamentos para a Crítica da Economia Política). In- Marx-Engels-Werke (MEW) Volume 42. Berlin: Dietz Verlag Berlin, 1983.

METAMIG. Ouro. Belo Horizonte, Governo do Estado de Minas Gerais, 1981

MOREIRA, M.A. Aprendizagem Significativa. Brasília: Universidade de Brasília,1999.

MORTIMER, E.F. Para além das fronteiras da Química: relações entre filosofia, psicologia e ensino de Química. Química Nova. São Paulo, v.20, n.2,1997.

As Chamas e os Cristais Revisitados: estabelecendo diálogos entre a linguagem científica e a linguagem cotidiana no ensino das Ciências da natureza. 
In:SANTOS.S,W.L.P. e MALDENER,O.A. (Orgs.) Ensino de Química em Foco. ljuí:Ed.Unijuí, 2010.

NEHRING,C.M.; SILVA,C.C.; TRINDADE,J.A.O.; PIETROCOLA,M.; LEITE, R.C.M.; PINHEIRO,T.F. As ilhas de racionalidade e o saber significativo: 0 ensino de ciências através de projetos. ENSAIO- Pesquisa em Educação em Ciências. Universidade Federal de Minas Gerais, Belo Horizonte, vol.02, № 1, 2002.

NOVAK,J.D.;CAÑAS,A.J. A teoria subjacente aos mapas conceituais e como elaborá-los e usá-los. Práxis Educativa. Tradução de Luis Fernando Cerri.Ponta Grossa, v.5, n.1, jan/jun. 2010.

PAVANELLO,R.M..Conceito científico e conceito cotidiano: algumas considerações sobre ensinar e aprender matemática nas séries iniciais do ensino fundamental. In: Romanowski,J.P.; Martins, P.L.O.; Junqueira, S.R.A. (Org.). Conhecimento local e conhecimento universal:a aula e os campos do conhecimento. Curitiba: Champagnat, 2004.

PINHO ALVES, J.Fo․ Regras da transposição didática aplicadas ao laboratório didático. Caderno Brasileiro de Ensino de Física. UFSC, Florianópolis, v.17, n 2, 2000.

PRESTES, Z. Quando não é quase a mesma coisa: análise de traduções de Lev Semionovitch Vigotski no Brasil, repercussões no campo educacional. 2010. 295p. Tese (Doutorado em Educação), Faculdade Educação, Universidade de Brasília, Brasília, 2010.

ROCHA-FILHO,C.R; TOLENTINO,M.; SILVA,R.; TUNES,E.; SOUSA,E.C.P. Ensino de Conceitos em Química.III Sobre o conceito de substância. Química Nova. São Paulo, 11 (4), 1988.

RUDNIOVA, E.I. Pedologuitcheskie izvraschenia Vigotskogo (Sobre as deturpações pedológicas de Vigotski). Moskva: Kniga po Trebovaniu, 2012.

SAKHAROV, L. Methods for investigating concepts. Psikhologija, 3, Soviet Psychology. Tradução de Michel Vale. Moscou, Julho/Agosto. 1990.

SENNET, R. O artífice. Rio de Janeiro, Ed. Record, 2009

SILVA,R.;TUNES,E. TOLENTINO,M.; ROCHA-FILHO,C.R;Ensino de Conceitos em Química II Matéria: Um sistema conceitual quanto a sua forma de apresentação. Ciência e Cultura. São Paulo, 38 (12), 1986.

SILVA, R.R. A Química deve ser ensinada a partir do concreto. Sala de aula. São Paulo, ano 3, n18, mar.1990.

SOUSA,R.M.; ECHEVERRIA,A.R.; COSTA, L.S.O. Educação Profissional para Jovens e Adultos: do conhecimento cotidiano ao conhecimento científico, um caminho de superação? In: XIV Encontro Nacional de Ensino de Química. Curitiba: 2008. 
TOLENTINO,M.;ROCHA-FILHO,C.R; SILVA,R.;TUNES,E. Ensino de Conceitos em Química I Matéria: Exemplo de um sistema de conceitos científicos. Ciência e Cultura. São Paulo, 38 (10), 1986.

TOULMIN, S. La comprensión humana - el uso colectivo y evolución de los conceptos. Madrid:Alianza Editorial, 1977.

. L' Explication Scientifique. Paris: Armand Colin, 1973.

TUNES, E.; BARTHOLO, R. S. Da constituição da consciência a uma Psicologia ética: alteridade e zona de desenvolvimento proximal. In Simão, L. M.; Mitjáns, A. (Orgs.) O outro no desenvolvimento humano: diálogo para a pesquisa e a prática profissional em Psicologia. São Paulo: Pioneira Learning Thomson, 2004.

TUNES,E. Preconceito, inclusão e deficiência-o preconceito no limiar da deficiência. In Tunes,E. e Bartholo,R.(orgs.) Nos Limites da Ação: Preconceito, Inclusão e Deficiência. São Carlos, UFSCAR,2007.

TUNES, G.; BARTHOLO,R.; TUNES,E. Três tempos do desenvolvimento situado. Revista OIKOS. Rio de Janeiro, v.5, n.2. 2006. Disponível em: $<$ www.revistaoikos.org. $>$ Acesso em: 24 ago.2011.

TUNES, E; CARNEIRO, M.H.S. Desenvolvimento e aprendizagem. In Curso de Pedagogia para professores em exercício no início de escolarização - PIE: Eixo Integrador: Escola como instituição social. Brasília: Faculdade de Educação, Universidade de Brasília, 2002.

TUNES,E. Os conceitos científicos e o desenvolvimento do pensamento verbal. Cadernos CEDES. Campinas, n.35, jul.2000.

VYGOTSKI, L. S. Obras Escogidas II. Pensamiento y Linguagem. Tradução de José Maria Bravo.Madrid: Visor, 1997a.

Obras Escogidas V. Fundamentos de Defectologia. Tradução de Julio Guillermo Blank.Madrid: Visor, 1997b.

. Obras Escogidas III. Historia del desarrollo de las funciones psíquicas superiores. Tradução de Lydia Kuper. Madrid: Visor, 1997c.

Obras Escogidas I. Problemas teóricos y metodológicos de la Psicología. Tradução de José Maria Bravo. Madrid: Visor, 1997d.

VIGOTSKI, L. S. A Construção do Pensamento e linguagem. Tradução de Paulo Bezerra. São Paulo: Martins Fontes, 2001.

$\overline{\text { Artmed, }} 2003$.

Psicologia pedagógica. Tradução de Claudia Schilling.Porto Alegre: 
Teoria e Método em Psicologia. Tradução de Claudia Berliner. São Paulo: Martins Fontes, 2004.

Pensamiento y habla. Tradução de Alejandro Ariel González. Buenos Aires: Colihue, 2007.

A brincadeira e o seu papel no desenvolvimento psíquico da criança. Tradução Zoia Prestes. Revista Virtual de Gestão de Iniciativas Sociais. Universidade Federal do Rio de Janeiro. Rio de Janeiro, №11, 2008.

Ática, 2009.

Imaginação e criação na infância. Tradução de Zoia Prestes. São Paulo:

Sobre a análise pedológica do processo pedagógico. Tradução de Zoia Prestes. In PRESTES, Z.Quando não é quase a mesma coisa: análise de traduções de Lev Semionovitch Vigotski no Brasil, repercussões no campo educacional. 2010. 295p. Tese (Doutorado em Educação), Faculdade Educação, Universidade de Brasília, Brasília, 2010.

VOLKOGONOV, D.A. Stalin:triunfo e tragédia. Tradução de Joubert de Oliveira Brízida. Rio de Janeiro: Nova Fronteira, 2004.

VYGOTSKY,L.S.; LURIA, A.R. Estudos sobre a história do comportamento: 0 Macaco, O Primitivo e Criança. Tradução de Lólio Lourenço de oliveira. Porto Alegre: Artes Médicas, 1996.

VYGOTSKY, L.S. The collected works of L.S Vygotsky.vol.5. Child psychology. Tradução de Marie J. Hall.New York: Plenum Press, 1998.

ZANATTA, B. A. O método intuitivo e a percepção sensorial como legado de Pestalozzi para a Geografia Escolar. Cadernos CEDES,Campinas,vol .25,n.66, p.165-184, maio/ago. 2005.

WEIL, S. O Enraizamento. Tradução de Maria Leonor Loureiro, Editora da Universidade do Sagrado Coração - EDUSC, Bauru, 2001. 
APÊNDICE A 


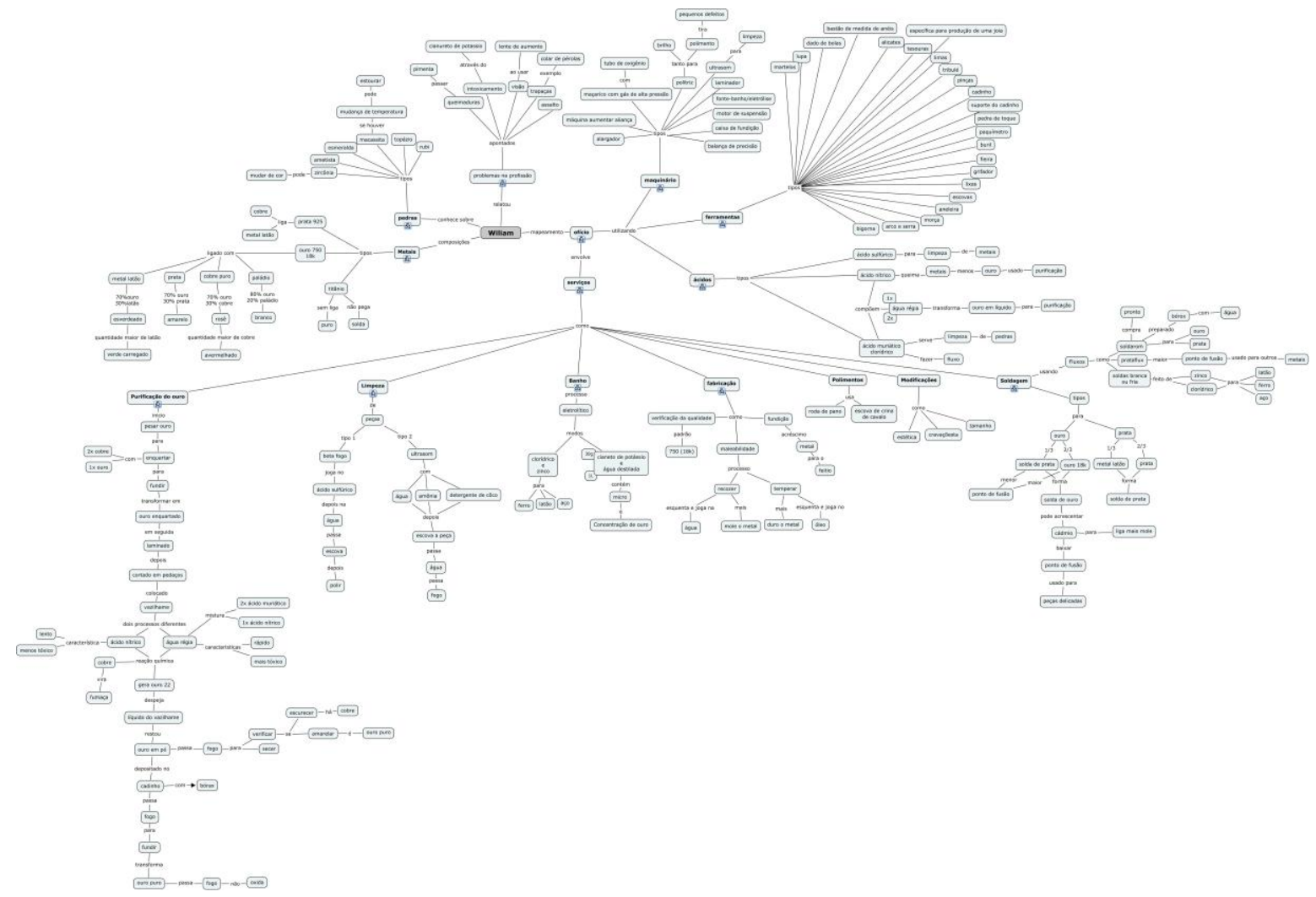

Figura 114- Mapa conceitual geral do ourives William. 


\section{APÊNDICE B}




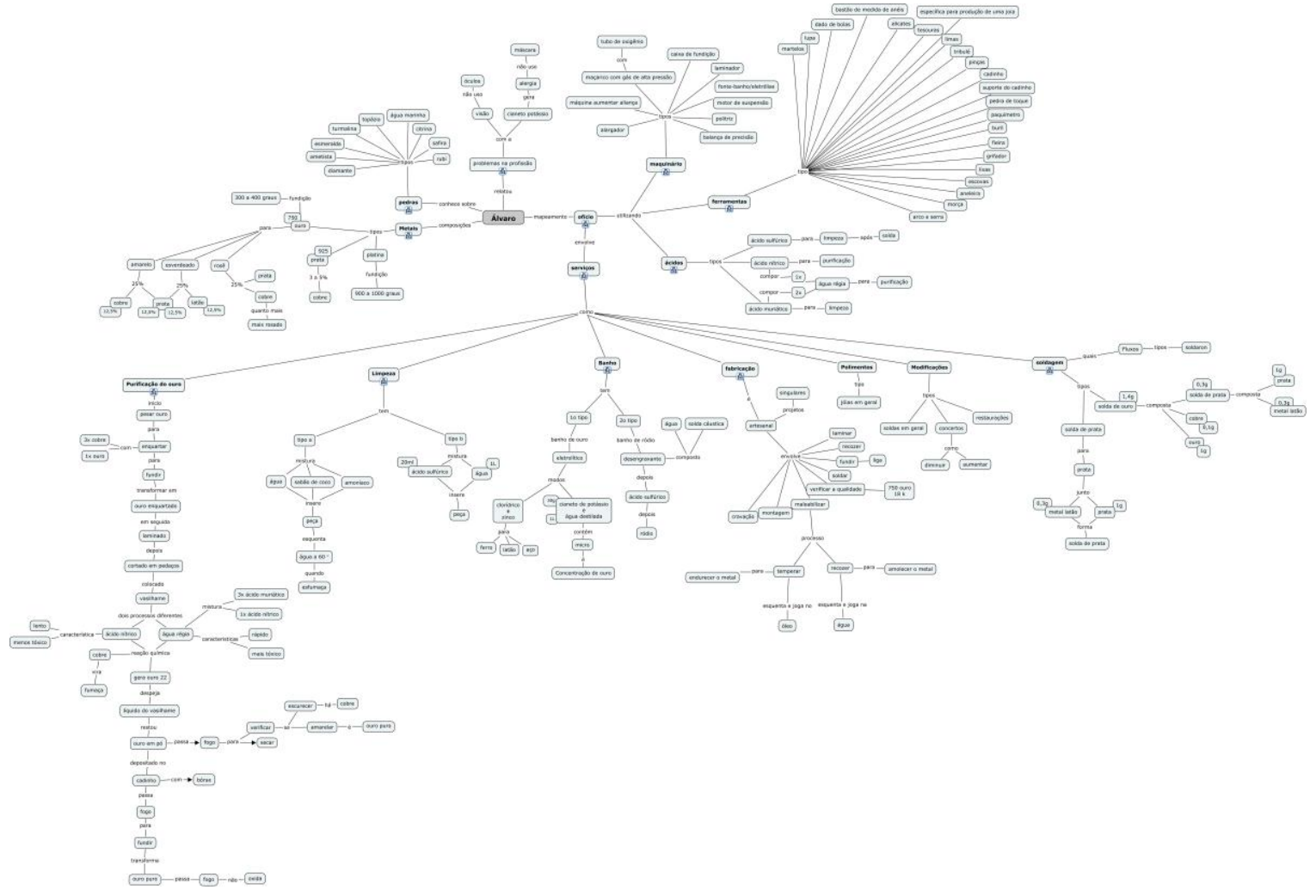

Figura 115- Mapa conceitual geral do ourives Álvaro. 
ANEXO A 


\section{FOCO}
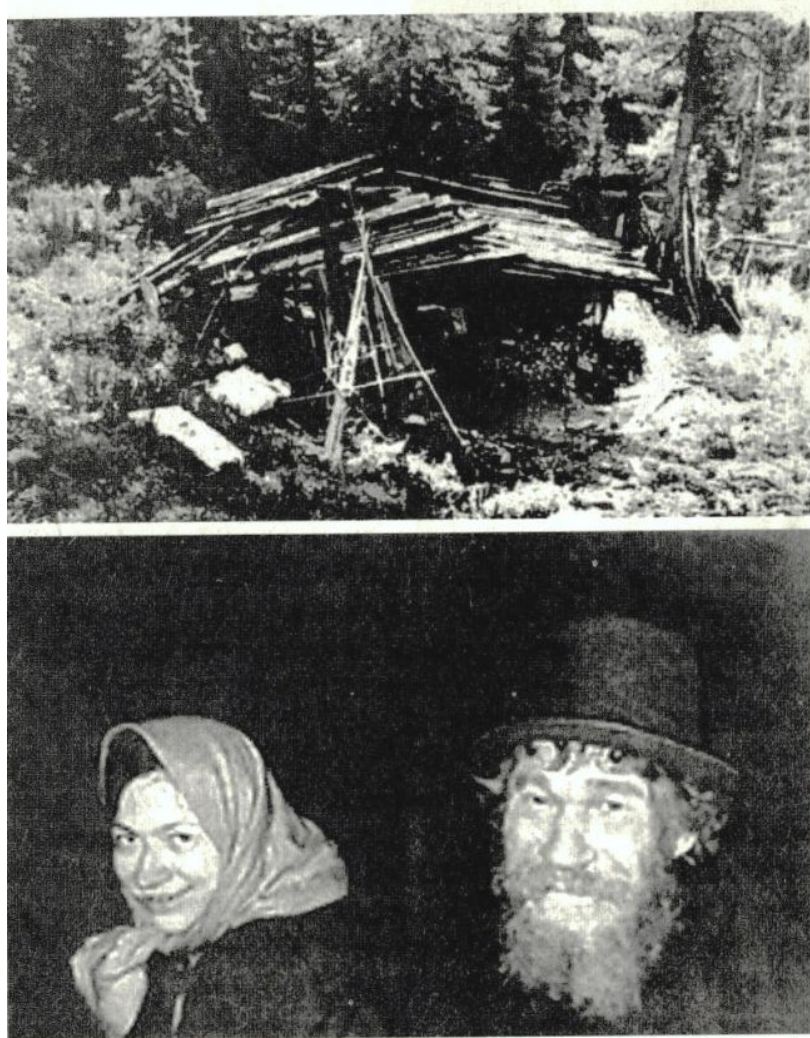

A nartir do alto. em sentido horário: a cabana, Agafia (esq.)

\section{Sobrevivente de família russa isolada do mundo continua a viver na Sibéria}

DE SÃO PAULO

A única sobrevivente de uma família russa que se afastou do contato com a civilização durante mais de 40 anos completa 70 anos vivendo no mesmo lugar em que foi achada - uma montanha a 1.800 m de altura e a $250 \mathrm{~km}$ de distância de qualquer povoado, nas profundezas da Sibéria.

A história de Agafia Lykov e sua família - contada em recente reportagem da revista do instituto Smithsonian-foi descoberta em 1978, quando geólogos a bordo de um helicóptero detectaram sinais de presença humana em área supostamente inabitada no sul da então União Soviética.

Após chegar ao local com dificuldade, os geólogos encontraram numa cabana rudimentar o patriarca Karp Lykove seus quatro filhos (Sa- vin, Natalia, Dmitri e Agafia). Descobriu-se que a família pertencia a uma seita ortodoxa fundamentalista - os Velhos Crentes, perseguidos desde os tempos do czar Pedro, o Grande (1672-1725) - e tinha fugido para a Sibéria em 1936 para se esconder da ditadura de Josef Stálin (1878-1953), que matara umirmão de Karp.

Os Lykov desconheciam a Segunda Guerra (1939-45), e as crianças nunca haviam visto um pão. Isolados, improvisavam roupas eutensílios com materiais da taiga, a floresta siberiana. Em 1961, quando o inverno destruiu o que cultivavam, a mulher de Karp, Akulina, morreu de inanição.

Depois do contato com os geólogos, morreram os três irmãos de Agafia, em 1981, e Karp, em 1988. A sobrevivente persiste. "Deus proverá", disse ela no enterro do pai. 